\title{
O controle da poluição das águas nas fronteiras: tratados internacionais e sua exigibilidade na proteção ambiental
}

Silene Bueno de Godoy Purificação

Tese apresentada ao Programa de PósGraduação em Saúde Pública para obtenção do título de Doutor em Saúde Pública.

Área de concentração: Saúde Ambiental Orientador: Prof. Dr. Aristides Almeida Rocha

São Paulo

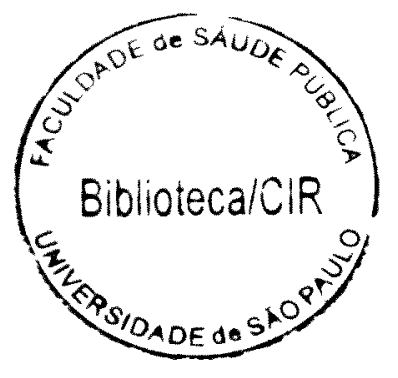

2.004 
Autorizo, exclusivamente para fins acadêmicos e científicos, a reprodução total ou parcial desta tese, por processos fotocopiadores.

Assinatura:

Data: 
"A felicidade não é uma estação na qual chegaremos, mas sim uma forma de viajar."

(Margaret Lee Runbeck) 
Ao meu Deus, por Ele e para a construção da Sua obra todo o meu empenho, todo o meu trabalho e estudo são oferecidos.

Aos meus Cyros, meu marido e meu filho, meus parceiros na luta da vida, com todo o meu amor, carinho e respeito.

Ao Prof. Dr. Michéas Bueno Godoy que me iniciou nas cièncias ambientais, me ensinou a trabalhar nessa área e me permitiu compartilhar consigo os caminhos da saúde ambiental.

Aos meus pais pela oportunidade da vida e pelo incentivo aos primeiros passos nos estudos.

À Prof . Priscilla Maria Bonini Ribeiro por seu apoio e pela especial parceria profissional no âmbito acadêmico. 


\section{AGRADECIMENTOS}

Os meus sinceros e profundos agradecimentos ao Professor Doutor ARISTIDES ALMEIDA ROCHA pela imensa honra de tê-lo como orientador, pela orientação prestada com dedicação, pelo constante incentivo e auxílio na realização deste trabalho, e, principalmente pela amizade e carinho que espero poder sempre retribuir.

Aos Professores Doutores ALEJANDRO JORGE DORADO, PEDRO CAETANO SANCHES MANCUSO, SUELI GANDOLFI DALLARI, MURILO DAMATO e JOSÉ LUIZ NEGRÃO MUCCI, agradeço a honra de tê-los como membros da banca examinadora desta tese e pelas sugestões que contribuiram para a elaboração deste trabalho.

Ao Professor Doutor JOSÉ MEDALHA agradeço pelo carinho e entusiasmo com que aceitou participar da banca examinadora desta tese, agradeço especialmente pela dedicação e pela atenção nas inúmeras sugestões que contribuiram para a melhoria na forma e no conteúdo deste trabalho.

Aos professores da Faculdade de Saúde Pública da Universidade de São Paulo, dos quais tive a honra de ser aluna, por me ensinarem o pensamento ecológico, epidemiológico e coletivo, parte fundamental para compreensão da saúde pública.

Aos funcionários do Centro de Pós-Graduação e da Biblioteca da Faculdade de Saúde Pública da Universidade de São Paulo, pela presteza e eficiência de seu trabalho que não ocultam o sorriso e a simpatia de seu pronto atendimento. 


\section{RESUMO}

Purificação SBG. O controle da poluição das águas nas fronteiras: tratados internacionais e sua exigibilidade na proteção ambiental. São Paulo; 2004. [Tese de Doutorado - Faculdade de Saúde Pública da USP].

O presente trabalho demonstra os problemas de controle da poluição das águas nas regiões de fronteira e a importância dos tratados internacionais na defesa do meio ambiente, sob o aspecto técnico da saúde ambiental, considerando de maneira global os diversos fatores: químicos, físicos, biológicos, econômicos, culturais e sociais que, direta ou indiretamente, interagem no meio ambiente. Dessa forma o estudo procedeu a uma análise das bacias hidrográficas no Brasil, identificando os corpos d'água nas regiões fronteiriças, evidenciando os problemas de controle da poluição ambiental das águas, sob os princípios constitucionais da soberania, da independência nacional, da auto-determinação dos povos, da não-intervenção, da igualdade entre os Estados, da cooperação dos povos para o progresso da humanidade. O trabalho desenvolveuse a partir do levantamento dos tratados internacionais relativos ao controle da poluição das águas, da legislação brasileira, dos organismos internacionais que atuam na promoção da qualidade das águas nas regiões de fronteiras e dos aspectos doutrinários relativos ao tema. Os resultados são analisados segundo o seu principal objeto, qual seja, o controle da poluição da água visando à qualidade ambiental e à saúde pública, a responsabilidade por danos ambientais nas regiões fronteiriças e a exigibilidade da observância das normas internacionais no que respeita à proteção ambiental e bem assim a universalidade dos parâmetros de controle da poluição das águas.

Descritores: Teses Acadêmicas. Saúde Pública. Estudos Ambientais. 


\section{SUMMARY}

Purificação SBG. The control of the pollution of the waters in the borders: treated international and its liability in the ambient protection. São Paulo; 2004. [Thesis of Doctor's degree - University of Public Health of USP]

The present work demonstrates the problems of water pollution control in the regions of border and the importance of the international treats in the defense of the environment, under the technician aspect of the ambient health, considering in global way the diverse factors: chemical, physical, biological, economic, cultural and social that, directly or indirectly, interact in the environment. From that point, the study proceeded to an analysis of the basins of the Brazilian hydrography, identifying water bodies in the bordering regions, evidencing the problems of environment related to the control of waters pollution, under the principles constitutional of the sovereignty, of national independence, of countries self-determination, of the not-intervention, of the equality between the States, of the cooperation of countries for the progress of the humanity. The work was developed from the fact-finding of international treats related to the control of waters pollution, of the Brazilian law, of the international organisms that act in the promotion of the quality of waters in the regions of borders and related to the doctrinal aspects to the subject. The results are analyzed according to its main object, which is, the control of the pollution of the water aiming at to the environment quality and the public health, the responsibility for environment damages in the bordering regions and the liability of the observance of the international norms taking into consideration the ambient protection and also the universality of the parameters of waters pollution control.

Descriptors: Academic thesis. Public health. Environmental estudies. 


\section{ÍNDICE}

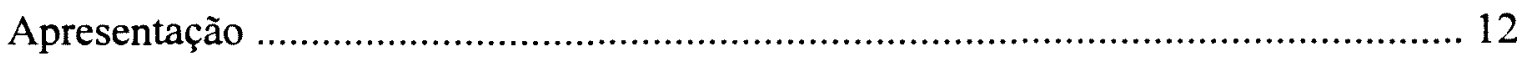

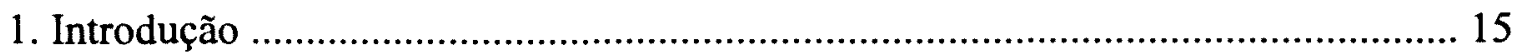

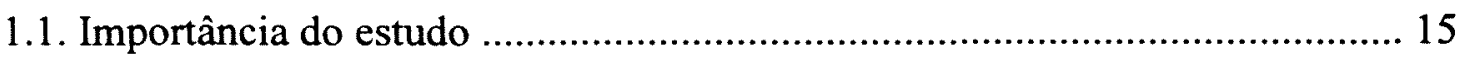

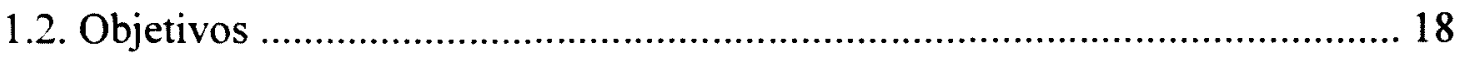

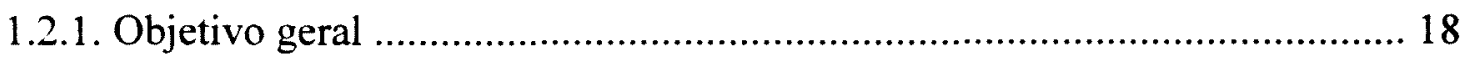

1.2.2. Objetivo específico .......................................................................... 18

1.3. Delimitação da abrangência do tema …………………………………...... 19

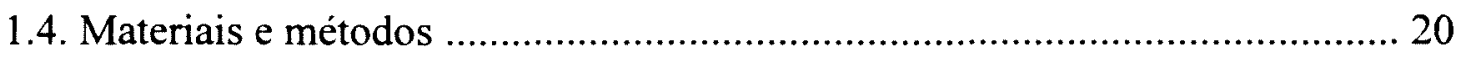

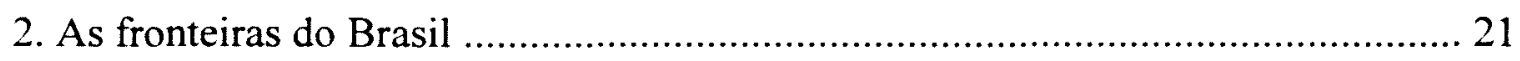

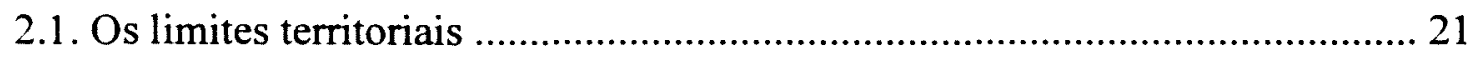

2.2. Fronteiras e limites do Brasil ..................................................................... 23

2.2.1. Fronteira Brasil-Peru ...................................................................... 26

2.2.2. Fronteira Brasil-Colômbia ................................................................ 29

2.2.3. Fronteira Brasil-Venezuela ............................................................... 32

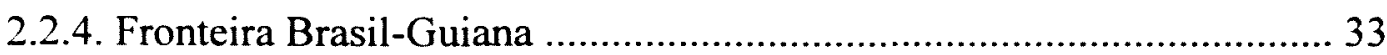

2.2.5. Fronteira Brasil-Suriname …………………….............................. 35

2.2.6. Fronteira Brasil-Guiana Francesa .................................................. 36

2.2.7. Fronteira Brasil-Bolívia .............................................................. 38

2.2.8. Fronteira Brasil-Paraguai ............................................................... 50

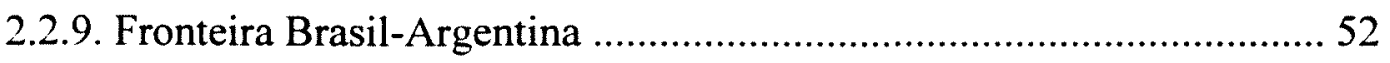

2.2.10. Fronteira Brasil-Uruguai …………………….............................. 54

2.3. Bacias hidrográficas e os rios brasileiros ................................................... 62

2.3.1. Principais características dos rios brasileiros ..................................... 62

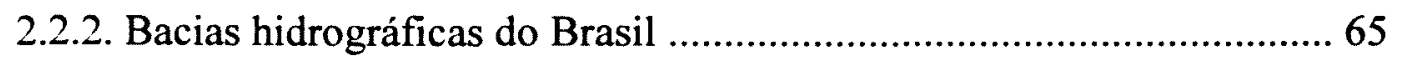

2.2.3. Nova classificação das bacias hidrográficas conforme legislação

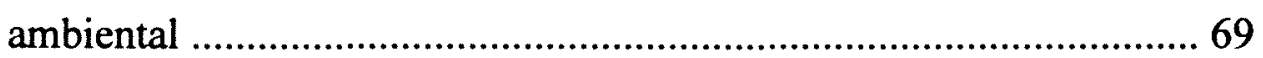




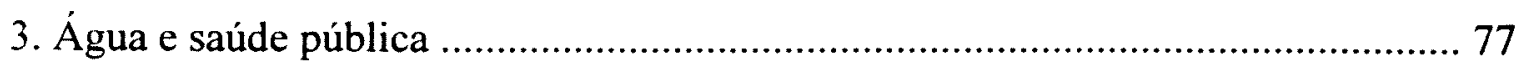

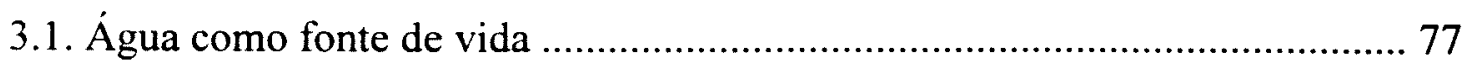

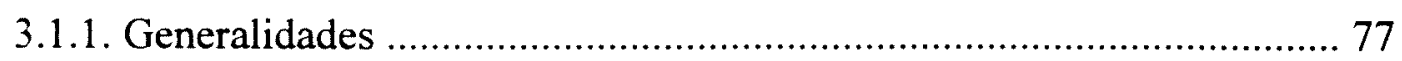

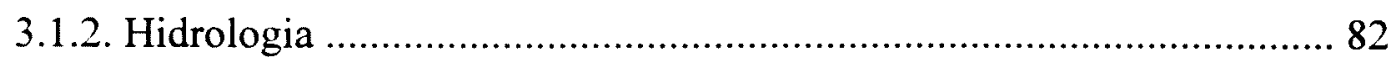

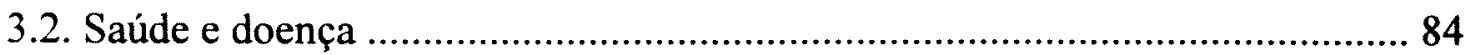

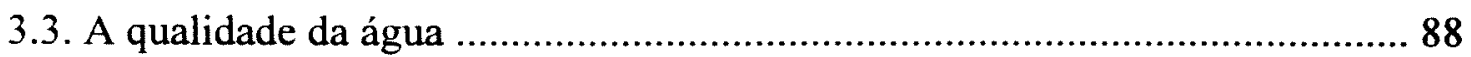

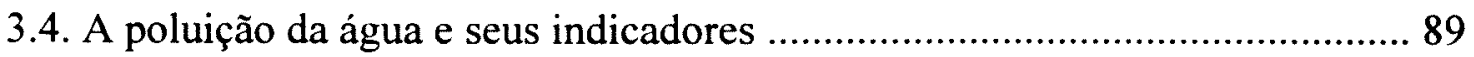

3.5. Os parâmetros de controle de poluição das águas .......................................... 95

4. Os instrumentos internacionais de proteção ambiental ....................................... 114

4.1. O direito nas diferentes nações do mundo ................................................... 114

4.2. O direito ambiental internacional ......................................................... 127

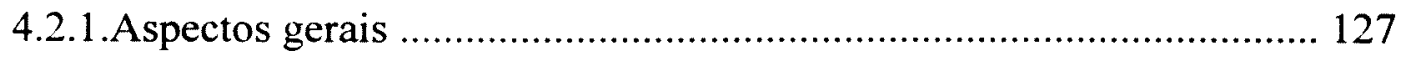

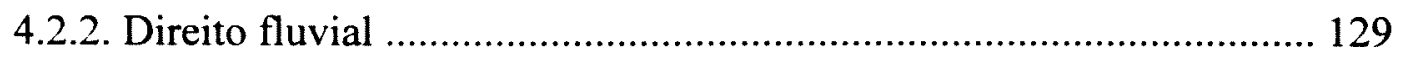

4.2.3. Aspectos ambientais no direito fluvial internacional ....................... 132

4.3. As convenções e os tratados internacionais ambientais .............................. 137

4.4. O papel das organizações não governamentais e das organizações intergovernamentais na questão ambiental ............................................. 145

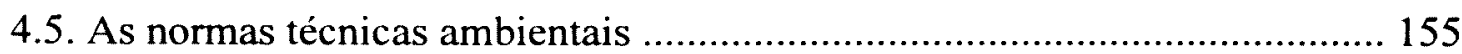

5. Exigibilidade dos tratados internacionais de proteção ambiental ........................ 160

5.1. Validade interna dos tratados internacionais ambientais ............................. 160

5.2. Efetividade do Direito Ambiental Internacional e Soberania ...................... 174

5.3. A premência de uma postura ética para o efetivo desenvolvimento sustentável em âmbito internacional ....................................................................... 185

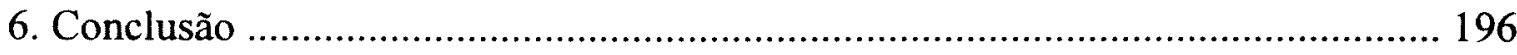

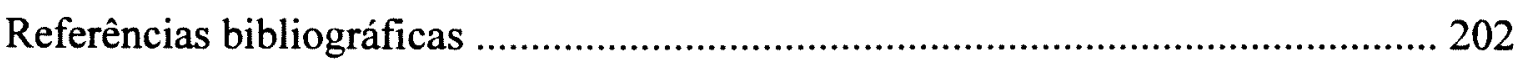

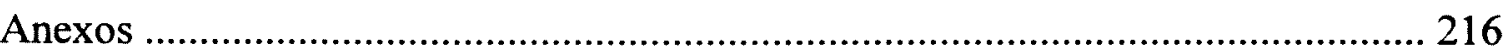

A1. Convenção das Nações Unidas sobre o direito das utilizações dos cursos d'água internacionais para fins distintos da navegação .............................. 216

A2. Resolución sobre las aguas subterráneas transfronterizas ............................ 231

A3. Atos internacionais sobre meio ambiente no direito brasileiro ................... 233

A4. Norma para classificação dos cursos d'água brasileiros quanto ao domínio 255 


\section{LISTA DE TABELAS}

Tabela 1. Fronteiras e limites do Brasil ................................................................... 24

Tabela 2. Navegação fluvial para transporte de cargas ........................................63

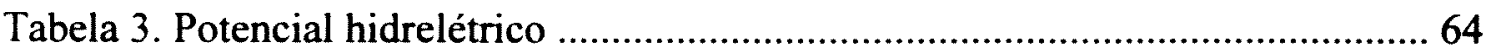

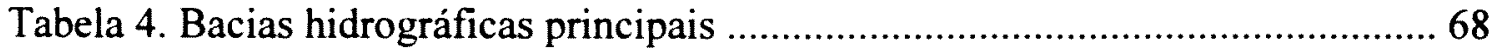

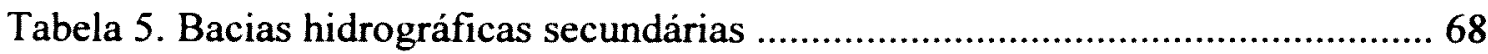




\section{LISTA DE FIGURAS}

Figura 1. América do Sul - Divisão Política .................................................... 25

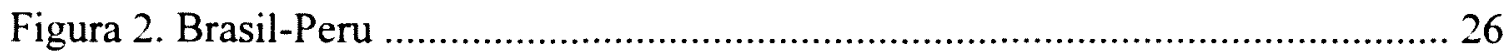

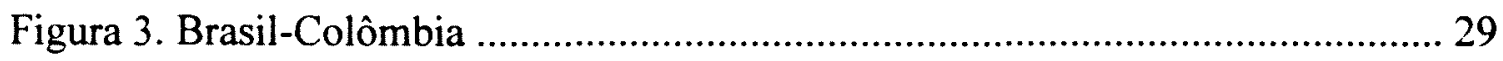

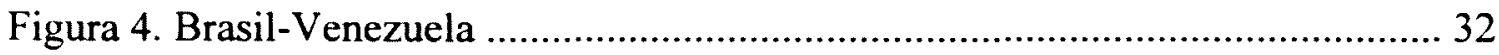

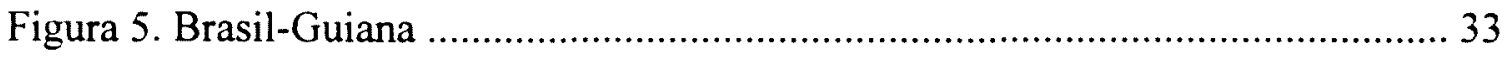

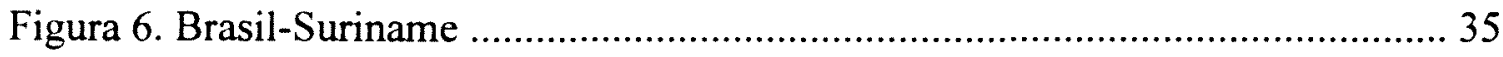

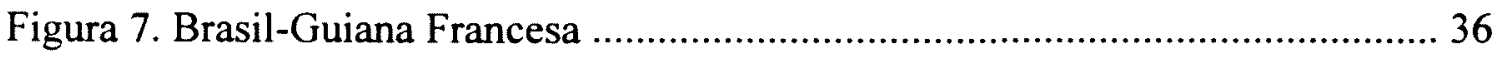

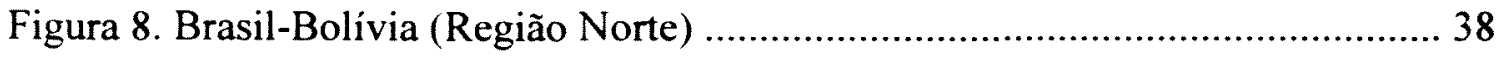

Figura 9. Brasil- Bolívia (Região Central) ........................................................ 42

Figura 10. Brasil- Bolivia (Região Sul) ......................................................... 48

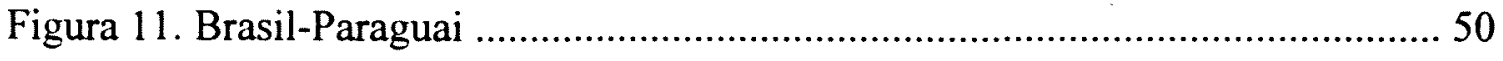

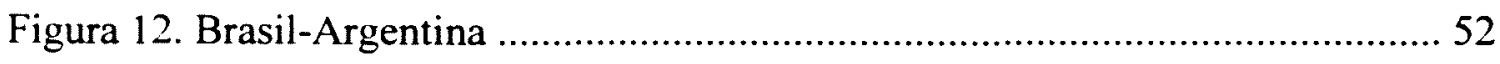

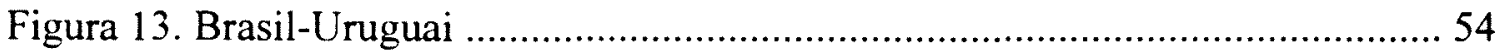

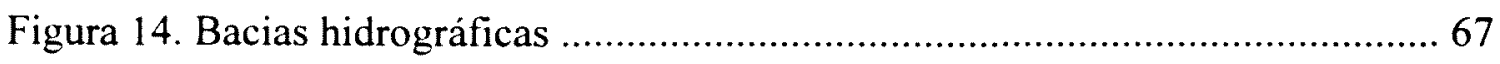

Figura 15. Representação das regiões hidrográficas ........................................... 71

Figura 16. Nível 2 de codificação das bacias e regiões hidrográficas ..................... 71

Figura 17. Codificação de bacias hidrográficas (Nível 1) ................................... 72

Figura 18. Divisão Hidrográfica Nacional ..................................................... 74

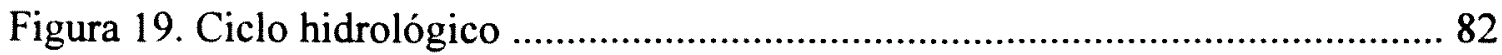

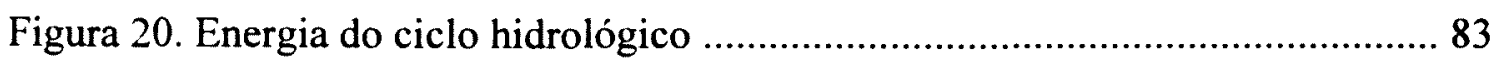

Figura 21. Fontes de poluição da água: fonte doméstica (esgoto) ........................... 91

Figura 22. Fontes de poluição da água: fontes industriais e agrícolas ..................... 92

Figura 23. Transporte de poluentes tóxicos no ecossistema aquático ..................... 93

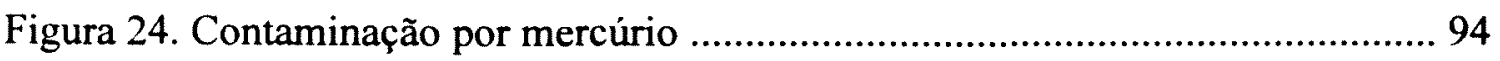

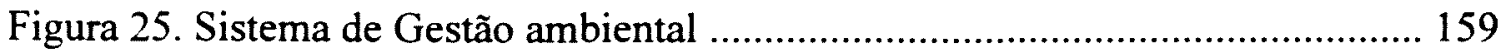




\begin{abstract}
"Eu, a sabedoria, habito no conselho, e me acho presente aos pensamentos judiciosos. O temor do Senhor aborrece o mal: eu detesto a arrogância, e a soberba, e o caminho corrompido, e a boca de duas línguas. Meu é o conselho, e a eqüidade, minha é a prudência, minha é a fortaleza. Por mim reinam os reis, e por mim decretam os legisladores o que é justo. Por mim imperam os príncipes, e os poderosos decretam a justiça..."
\end{abstract}

\title{
APRESENTAÇÃO
}

Segundo a lenda, um menino apanhava estrelas-do-mar na areia da praia e as atirava de volta à água o mais longe que a força de seu pequeno braço lhe permitia. Uma após outra ele avançava pela faixa amarelada, o sol da manhã dourando tudo, devolvendo ao mar as estrelas de direito. Um homem que passava indagou-lhe sobre o propósito de seu gesto. - Elas vieram com a maré alta e não foram rápidas o bastante para voltar. Quando o sol esquentar, vão morrer presas na areia - o menino disse, apanhando mais uma estrela. $O$ homem, então, argumentou que havia centenas de estrelas-do-mar presas naquela praia e milhares de outras que terminavam seus dias assim. na esperança do suspiro de qualquer onda afoita que as arrastasse de volta ao mundo submarino. O trabalho do menino não seria capaz de mudar aquele quadro. - Eu não quero desapontá-lo, mas não vai fazer nenhuma diferença - o homem disse enquanto menino soprava a areia do corpo da estrela que tinha nas mãos. O menino, então, devolveu-a ao mar, olhou para o homem e sorriu: - Para essa eu fiz a diferença - ele respondeu enquanto a estrela afundava no mar brilhante da manhã. - Para essa eu fiz a diferença. ${ }^{2}$

\footnotetext{
1 “...Eu amo aos que me amam: e os que vigiam desde a manhã por me buscarem, achar-me-ão. Comigo estão as riquezas, e a glória, a magnifica opulência, e a justiça. Porque melhor é o meu fruto que o ouro, e que a pedra preciosa, e as minhas produções melhores que a prata escolhida. Eu ando nos caminhos da justiça, no meio das veredas do juizo. Para enriquecer aos que me amam, e para encher os seus tesouros". (SALOMÃO, Provérbios 8, 12-21).

${ }^{2}$ Autor desconhecido.
} 
$\dot{E}$ entendimento corrente que o profissional de meio ambiente é hoje como o menino da lenda. Sente-se. muitas vezes solitário em sua jornada, como um Dom Quixote, vislumbrado por Cervantes, a enfrentar moinhos de vento, uma cruzada romântica, desafiadora, na busca do que é moral, eterno, galante, heróico ciente de que suas ações são, na grande maioria das vezes, de eficácia local e pontual.

Foi de forma apaixonada que me entreguei à questão ambiental e como tal tenho pautado minhas ações, seja como advogada atuante em processos administrativos e judiciais, seja como consultora juridica na esfera ambiental, seja, ainda e principalmente, na educação, como multiplicadora da necessária conscientização da importância do meio ambiente, da sustentabilidade do desenvolvimento humano, em seu âmbito sócio-econômico e, em especial no respeito à dignidade humana que inclui seu inalienável direito à sadia qualidade de vida.

Nos caminhos ambientais que tenho trilhado, tenho tido a mais grata felicidade de encontrar profissionais da mais alta competência e dedicação à questão ambiental. Muito tenho aprendido, mais a mais querida lição tem sido o amor e a lealdade ao meio ambiente, em seu mais amplo sentido e alcance.

A questão ambiental deve ser estudada em seus múltiplos aspectos, devendo, em qualquer hipótese, prevalecer o da saúde pública, uma vez que no contexto ambiental os aspectos de saúde pública são constantemente inferidos, direta ou indiretamente, pelos efeitos do desequilíbrio ecológico ou poluição ambiental, uma vez que os agravos à saúde têm origem nas condições ambientais inadequadas. Portanto, a poluição ambiental é um problema de saúde pública e o saneamento do meio, que inclui o controle da poluição das águas, um dos objetivos desta. 
Saúde, segundo definição da Organização Mundial da Saúde, é um estado de completo bem estar físico, mental e social e não apenas a ausência de doença. Pode-se substituir "bem estar físico, mental e social" como "adequada qualidade de vida", ou seja, somente se pode apresentar um bem estar físico, mental e social se estiver em um ambiente propício para isso, em todos os seus aspectos: de higiene, saneamento básico, psicológicos, sociais, estéticos e culturais.

$\dot{E}$, assim, o ambiente elemento essencial da saúde. Deve, portanto, ser estudado sempre sob o manto da saúde pública, com vistas à prevenção de agravos e melhoria da qualidade de vida.

Dai porque a escolha de freqüentar os bancos da Faculdade de Saúde Pública da Universidade de São Paulo, pioneira nos estudos ambientais no território brasileiro, para desenvolvimento dos meus trabalhos de pós-graduação, antes a dissertação para obtenção do grau de mestre, na qual foram abordados a legislação ambiental do Estado de São Paulo e o desenvolvimento sustentável, e agora, a tese para obtenção do grau de doutor, buscando demonstrar a exigibilidade dos tratados internacionais no controle da poluição das águas nas regiões de fronteira. A amplitude do tema e as multifaces que ele encerra somente seriam possiveis de serem analisadas num ambiente que congrega valores de todas as áreas do conhecimento. Trabalhar a questão ambiental sob o único aspecto do direito, como seria esperado, até mesmo considerando a temática de fundo - tratados internacionais e sua exigibilidade, não abrangeria o principal foco que é o controle da poluição das águas. A contribuição legal é sobremaneira importante, porém, em termos ambientais as leis da natureza falam mais alto e repercutem por mais tempo e além das fronteiras. A responsabilidade, então, deve ser abordada sob outros prismas além do legal, a moral intrínseca do espécime humano, como ser biológico antes mesmo do ser social. 


\begin{abstract}
"A lei não deve ser recebida como uma obrigação contratual e, muito menos, de efeito provisório. Ela deve ser entendida, sim, como preceito moral, fundamentada não na vontade dos governantes, mas baseada no próprio conceito de liberdade, segundo o qual a ninguém é dado o direito de usar predatoriamente o bem comum, ou comprometer a existência de bens naturais que serão indispensáveis às gerações futuras".
\end{abstract}

\title{
1. INTRODUÇÃO
}

\subsection{Importância do estudo}

A vida atual está inserida em uma política global onde a comunicação derrubou as últimas fronteiras da informação. É, pois, crescente a consciência de que a unidade dos povos é fundamental para a preservação da espécie humana e a aceitação do meio ambiente em que vivemos, considerado em todo o seu contexto (físico, econômico, político e cultural), é fator determinante no comportamento dos indivíduos e que esse comportamento se reflete de forma inexorável na própria sociedade (PURIFICAÇÃO, 2001).

Ora, em cada país do Globo há leis diversas para solução dos conflitos de interesses internos dos indivíduos que o compõe, havendo também normas especificas de proteção ambiental que regulam as atividades do homem, de acordo com as características e necessidades de cada região.

Entretanto, as questões ambientais muitas vezes se encontram restritas a um determinado território, não afetando somente determinado povo, mas sim várias localidades no entorno e, não raras vezes, interferem diretamente em todo o Planeta, atravessando fronteiras, em especial aquelas delimitadas por cursos d'água.

3 “... Este é o preceito fundamental, a 'regra de ouro' sob a qual se fundamenta a legislação ambiental" (BRANCO, 2002, p 221). 
A lei é a representação externa do dever ser em sociedade, é a exteriorização dos valores subjetivos a serem respeitados por todos os destinatários daquela norma (PURIFICAÇÃO, 2001).

Por outro lado, cada Estado tem sua soberania, que é o poder máximo de que está dotado para fazer valer suas decisões e sua autoridade dentro do seu território (COTRIM, 1992).

Embora existam acordos e tratados internacionais sobre o tema, nem todos os países são signatários dessas declarações de interesse geral. Como exigir a observância dos paises que não aderiram a esses acordos?

Será que um pais pode se negar a proceder ao controle da poluição ambiental de um curso d'água que atravessa as suas fronteiras e prejudica a população de outros paises que lhe são vizinhos? E qual o papel das Organizações Não Governamentais nesse contexto?

$\dot{E}$ ponto pacifico que o meio ambiente é elemento essencial para o desenvolvimento integral do homem, no qual está inserido o conceito de saúde, e desastrosas serão as conseqüências que colocarão em risco a sobrevivência da espécie humana, caso o equilibrio ecológico não seja uma constante.

Saúde pública é atividade social que tem por objetivo a promoção e preservação da saúde da população (FORATTINI, 1996). Para WISLOW (1980 appud MOREIRA, 1992), saúde pública é a ciência, a arte de prevenir doenças, prolongar a vida e promover a saúde e a eficiência física e mental, e o faz através dos esforços organizados da comunidade, visando ao saneamento do meio, ao controle das infecções na comunidade, à educação dos indivíduos nos princípios da higiene pessoal, à organização de serviços médicos e de enfermagem para o diagnóstico precoce e o tratamento preventivo das doenças, e ao desenvolvimento da máquina social para garantir, a cada indivíduo da comunidade, um padrão de vida adequado à manutenção da saúde. 
Muitos agravos à saúde tèm sua origem nas más condições ambientais, muitas vezes decorrentes da poluição das águas. Água que é fonte primordial da vida e que possui diversos usos, como abastecimento, irrigação, dessedentação, piscicultura, produção de energia, entre outros. Entretanto, para que se possam utilizar os benefícios da água sem risco à saúde, esta deverá apresentar determinados padrões de qualidade. Segundo SILVA (1998), pode-se verificar, a partir dos conhecidos aspectos quantitativos relacionados com o ciclo hidrológico e com a disponibilidade de água para suportar as atividades humanas, a existência de vários usos benéficos possiveis de serem definidos para os diversos sistemas aquáticos, os quais se tornam conflitantes, exigindo uma definição de propriedade que permita o seu controle. Assim, para assegurar um determinado uso, ou um conjunto de usos, é necessário que tais águas possuam certas características mensuráveis, de natureza física, química e biológica, mantidas dentro de intervalos de variação permissíveis e são essas caracteristicas que constituem uma nova dimensão da água, a qual se denomina qualidade.

Assim, sendo a poluição ambiental um problema de saúde pública e o saneamento do meio um dos objetivos desta, o controle da poluição dos cursos d'água nas fronteiras é de real importância, sendo os instrumentos para observância questão de relevante interesse, enquanto problema emergencial de saúde pública, uma vez que a contaminação da água é fonte de agravos maiores que colocam em risco não somente a qualidade de vida da população, mas a própria sobrevivência desta.

Como foi afirmado, entende-se que a questão ambiental não tem fronteira, ou seja, a poluição ambiental causada em determinada parte do Globo poderá resultar problemas ecológicos, econômicos ou de saúde à outra, ou outras regiões, ou, até mesmo, para a totalidade do Planeta. Dessa forma, não se pode admitir um controle setorial, em especial nas regiões de fronteira, especificamente quando se trata de cursos d'água, nos quais se torna mais dificil limitar em termos espaciais, a poluição àquele país que não observou os padrões de qualidade existentes. 
Por outro lado. não adiantam as declarações em tratados internacionais, se os paises se recusam a participar como signatários, ou, se o fazem, não se pode exigir o cumprimento pela ausência do elemento coativo, o qual, por sua vez, não pode violar a soberania de cada Estado. Necessário, portanto, um estudo sistemático dos mecanismos existentes para o controle da poluição do meio, em especial das águas, nas regiões de fronteira, que venha a interferir diretamente na manutenção da saúde dos diversos povos que compõem essas diferentes regiões.

\subsection{Objetivos}

\subsubsection{Objetivo Geral}

Como objetivo geral, o trabalho demonstra a importância para a saúde pública do controle da poluição das águas nas fronteiras, além dos limites legais impostos pela soberania territorial, sob os princípios constitucionais nas relações internacionais da independência nacional e da não-intervenção, bem como os meios disponiveis para exigir a realização desse controle por parte dos paises que utilizam as mesmas águas fronteiriças e que dependem de sua qualidade para a sobrevivencia de suas populações.

\subsubsection{Objetivo Específico}

Como objetivo específico, o estudo expõe, de forma sistematizada, as bacias hidrográficas existentes no território brasileiro, destacando os cursos d'água que fazem fronteira com paises vizinhos, bem como os tratados, acordos e declarações internacionais vigentes que dispõem sobre o controle da poluição das águas, qualificando e quantificando os instrumentos para esse controle nas fronteiras e sua exigibilidade frente à soberania do Estado, demonstrando, ainda, a importância das organizações não governamentais para a consecução dos objetivos de interesse global, no âmbito da saúde ambiental, especialmente no que respeita à qualidade da água, considerando ser esta fonte primária da vida. 


\subsection{Delimitação da abrangência do tema}

Para desenvolvimento do trabalho estudou-se o meio ambiente natural e social brasileiro que apresentam maiores riscos de poluição das águas nas fronteiras, as bacias hidrográficas brasileiras, suas características e principais rios, os rios que se constituem em fronteiras naturais do Brasil, os cursos d'água que ultrapassam as fronteiras brasileiras, seja na nascente ou desembocadura.

Estudou-se, também, os tratados, acordos e declarações firmados pelo Brasil na busca de um controle eficaz da qualidade da água e os demais mecanismos existentes para uma efetiva aplicação dos princípios do desenvolvimento sustentável como garantia da saúde coletiva, sem prejuizo do princípio da soberania dos povos, presente no Estado, seja ele signatário ou não dos tratados.

O trabalho abordou, ainda, a questão da ética nas relações internacionais, especificamente no que respeita ao meio ambiente. A consciência e a responsabilidade ambiental como elementos intrínsecos na moral, como valores remotos que se perderam na memória da humanidade e que precisam, agora, ser resgatados para a sobrevivència da vida em todas as suas formas.

Finalmente, o estudo se ocupou das organizações não governamentais e sua influência na realização dos tratados internacionais e, especialmente, na sua observância, com as especificações de competências e áreas de atuação dos organismos internacionais ligados à proteção ambiental e ao controle da poluição do meio, no que atine às águas de fronteira. 


\subsection{Materiais e métodos}

A pesquisa consubstanciou-se na identificação das fronteiras brasileiras, em suas bacias hidrográficas e nos cursos d'água que constituem os limites naturais do território brasileiro, suas características principais e os riscos ambientais preponderantes.

O trabalho fundamentou-se, também, no levantamento bibliográfico dos tratados, acordos e declarações internacionais na área do controle da poluição das águas nas regiões de fronteira do Brasil, bem como da doutrina existente a respeito do tema, em especial quanto aos instrumentos que proporcionam a sua exigibilidade e eficácia frente à soberania do Estado.

Finalmente, ainda no campo da pesquisa, procedeu-se ao levantamento dos principais organismos internacionais de controle e proteção ambiental, com estudo de sua estrutura e respectivas aplicações com indicação de atuação das organizações não governamentais na defesa da qualidade das águas, especificamente quanto aos riscos nas regiōes fronteiriças.

Buscou-se assim conhecer um quadro geral e sistematizado da situação atual do Brasil, no panorama internacional, no que respeita ao controle dos riscos que envolvem a qualidade ambiental de seus corpos d'água. 


\begin{abstract}
"A paisagem é sempre uma herança. Na verdade, ela é uma herança em todo sentido da palavra: herança de processos fisiográficos e biológicos, e patrimônio coletivo dos povos que historicamente a herdaram como território de atuação de suas comunidades (...). Mais do que simples espaços territoriais, os povos herdaram paisagens e ecologias, pelas quais certamente são responsáveis, ou deveriam ser responsáveis..."
\end{abstract}

\title{
2. AS FRONTEIRAS DO BRASIL
}

\subsection{Os limites territoriais}

O estudo geográfico atual pode utilizar vários pontos de partida, sendo duas as formas principais de abordagem, a saber:

a) tomando-se por princípio a referência terra. ou seja, o espaço físico, estuda-se as nações de acordo com o continente em que se localizam, considerando-se o território, tamanho, localização, forma de relevo, clima e vegetação, entre outros, sendo que os elementos humanos e econômicos são os últimos a serem observados;

b) por outro lado, pode-se abordar a questão sob o prisma da sociedade, ou seja, do homem, estuda-se, então, as nações sob o enfoque políticoeconômico. Nesse aspecto, serão considerados em primeiro plano o povo, suas instituições, sua organização política e suas atividades econômicas.

De acordo com VESENTINI (1999), para o estudo da geografia, o elemento terra, ou espaço físico, só teria maior importância que o elemento homem, se a natureza dominasse a sociedade humana, como já ocorreu no passado mais remoto, porém, hoje, o homem é que domina e modifica a natureza. Impõe-se, assim, uma nova abordagem conceitual.

\footnotetext{
4 “... Desde os mais altos escalões do governo e da administração até o mais simples cidadão, todos têm uma parcela de responsabilidade permanente no sentido da utilização não predatória dessa herança única, que é a paisagem terrestre. Para tanto, há que conhecer melhor as limitações de uso, especificas de cada tipo de espaço e paisagens (...)." (AB'SÄBER, 1992, p. 167).
} 
As sociedades atuais transformam a natureza original de seus territórios de acordo com os recursos técnicos e econòmicos de que dispõem. A modificação na paisagem ambiental é total, com desmatamentos e, por conseqüência alterações climáticas; com rios represados, desviados de seu curso original, com formação de lagos artificiais e aterramentos; solos corrigidos, impermeabilizados, morros e colinas recortados, aplainados; e com a presença da poluição atmosférica, ocasionando as chuvas ácidas, entre outros fatores, também responsáveis pela alteração da vegetação.

Em razão do desenvolvimento dos meios de transporte e de comunicação, também as distâncias territoriais ganham novo significado. Hoje se pode ir rapidamente de um ponto a outro do globo terrestre, bem como, em segundos, se estabelecer contatos simultâneos com pessoas de diversas localidades e distantes milhares de quilômetros.

Entende-se, pois, que o território brasileiro atual não foi uma simples dádiva da natureza, mas é fruto da ação humana, resultante de longo processo de povoamento, conquista e miscigenação, permeado de sacrificios, conflitos e tratados diplomáticos em evidente prejuízo ao povo indigena. Além disso, nossa ocupação territorial é incompleta e desequilibrada, com a maioria da população vivendo próxima do litoral. A densidade demográfica das áreas interiores é ainda baixa, o que traz como resultado na paisagem ambiental a quase extinção da Mata Atlântica, e a possibilidade de preservação, apenas, da vegetação das áreas não ocupadas totalmente pelo homem.

Diz-se, então, que o meio ambiente é dividido em meio cultural (produto da ação do homem), e meio natural (fruto da ação da natureza), sendo que com o desenvolvimento da industrialização e do capitalismo, o meio cultural passou a prevalecer significativamente sobre o meio natural e sobre a paisagem, que é cada vez mais modificada pela coletividade, ocupando gradativamente as áreas do território brasileiro, onde ainda predomina a natureza não humanizada. 
Assim, no estudo geográfico de determinada localidade, necessário se faz definir um novo conceito de territorialidade. $\dot{E}$ fundamental considerar o homem e suas constantes intervenções no meio ambiente, quando o estudo se dirige aos aspectos hidrográficos em especial. Dessa forma, não se pode olvidar a água (elemento possuidor de múltiplos usos), como maior alvo da ação antrópica.

\subsection{Fronteiras e limites do Brasil}

Com sua vasta dimensão, o Brasil é o quinto país do mundo em extensão territorial, ocupando parcela considerável da América do Sul. Está situado na parte centro-oriental do continente, ocupando $47,3 \%$ de sua área total, ou seja, quase metade de sua superfície.

Possui cerca de $16.000 \mathrm{~km}$ de fronteiras, limitando-se ao norte com a Guiana, Suriname, Guiana Francesa e Venezuela; a oeste com a Colômbia, Peru, Bolívia e Paraguai; ao sul, com a Argentina e o Uruguai; e a leste com o oceano Atlântico. Apenas dois países sul-americanos não têm fronteira com o Brasil, são o Equador e o Chile.

Seus pontos extremos localizam-se, ao norte, nas nascentes dos rios Ailã e Caburaí, junto ao monte Roraima, na fronteira com a Guiana; ao sul, na curva do arroio Chuí, na fronteira com o Uruguai; a oeste, nas nascentes do rio Moa, na fronteira com o Peru; a leste, na ponta do Seixas, no cabo Branco, no Estado da Paraíba, sendo que o ponto extremo leste insular é a ilha Martin Vaz, no oceano Atlântico (Enciclopédia Delta Universal, 1988, v. 3, p. 1432; Enciclopédia Larousse Cultural, 1990, v. 4, p. 892). 
Tabela 1 - Fronteiras e Limites do Brasil:

\begin{tabular}{|c|c|c|c|c|}
\hline \multicolumn{5}{|c|}{ FRONTEIRAS E LIMITES DO BRASIL 5} \\
\hline País & Totais & Linha Seca & Rios, Lagos e Canais & Nr.Marcos \\
\hline Guiana Francesa & $730 \mathrm{~km}$ & $303 \mathrm{~km}$ & $427 \mathrm{~km}$ & 10 \\
\hline Suriname & $593 \mathrm{~km}$ & $593 \mathrm{~km}$ & - & 60 \\
\hline Guiana & $1.606 \mathrm{~km}$ & $908 \mathrm{~km}$ & $698 \mathrm{~km}$ & 134 \\
\hline Venezuela & $2.199 \mathrm{~km}$ & $2.199 \mathrm{~km}$ & - & 2.682 \\
\hline Colômbia & $1.644 \mathrm{~km}$ & $835 \mathrm{~km}$ & $809 \mathrm{~km}$ & 128 \\
\hline Peru & $2.995 \mathrm{~km}$ & $992 \mathrm{~km}$ & $2.003 \mathrm{~km}$ & 86 \\
\hline Bolívia & $3.423 \mathrm{~km}$ & $751 \mathrm{~km}$ & $2.672 \mathrm{~km}$ & 438 \\
\hline Paraguai & $1.366 \mathrm{~km}$ & $437 \mathrm{~km}$ & $929 \mathrm{~km}$ & 910 \\
\hline Argentina & $1.261 \mathrm{~km}$ & $25 \mathrm{~km}$ & $1.236 \mathrm{~km}$ & 310 \\
\hline Uruguai & $1.069 \mathrm{~km}$ & $320 \mathrm{~km}$ & $749 \mathrm{~km}$ & 1.174 \\
\hline Total & 16.886 & 7.363 & 9.523 & 5.932 \\
\hline
\end{tabular}

Pode-se verificar pelos dados no quadro 1 que o primeiro país em limite territorial de fronteira com o Brasil é a Bolívia, com grande predominância de rios, lagos e canais.

Destaca-se, também no quadro a fronteira em águas do Brasil com a Argentina, ocupando praticamente toda sua extensão, com um minimo de limite em linha seca. Por outro lado, as fronteiras do Brasil com o Suriname e do Brasil com a Venezuela são totalmente em linha seca, não tendo cursos d'água como indicadores limítrofes.

\footnotetext{
${ }^{5}$ http://info.Incc.br/wrmkkk/tab.html
} 
Figura 1 - América do Sul - Divisão Política:

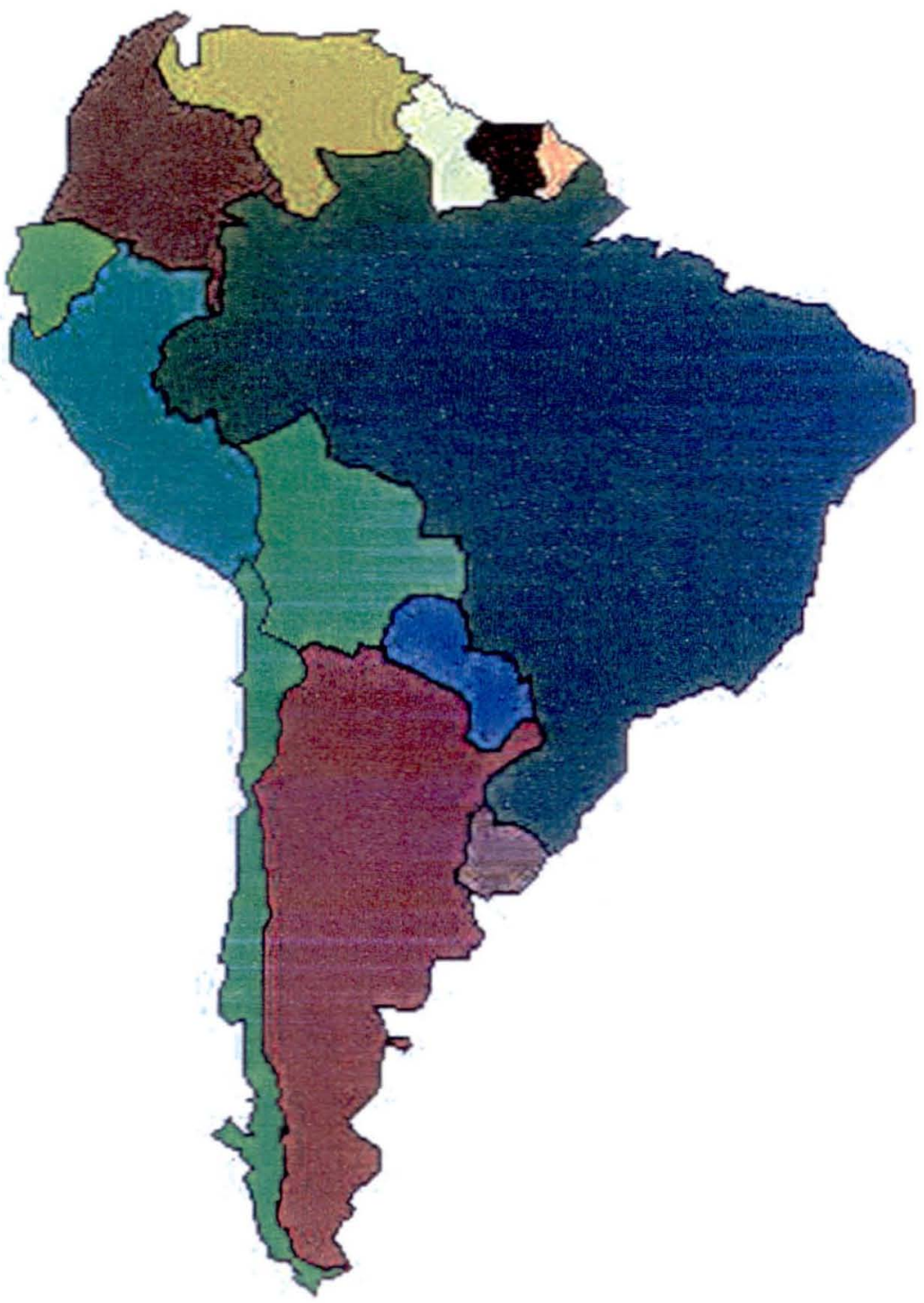

\begin{tabular}{|l|l|l|l|}
\hline Argentina & Brasil & Paraguai & Uruguai \\
\hline Bolívia & Peru & Venezuela & Suriname \\
\hline Colômbia & Guiana & Equador & \\
\cline { 1 - 2 } Chile & Guiana & Francesa & \\
\cline { 1 - 2 } & & &
\end{tabular}

Verifica-se na figura 1 que os únicos países do continente sul-americano que não dividem limites com o Brasil são o Chile e o Equador. 


\subsubsection{Fronteira Brasil-Peru ${ }^{6}$}

Figura 2 - Brasil-Peru ${ }^{7}$ :

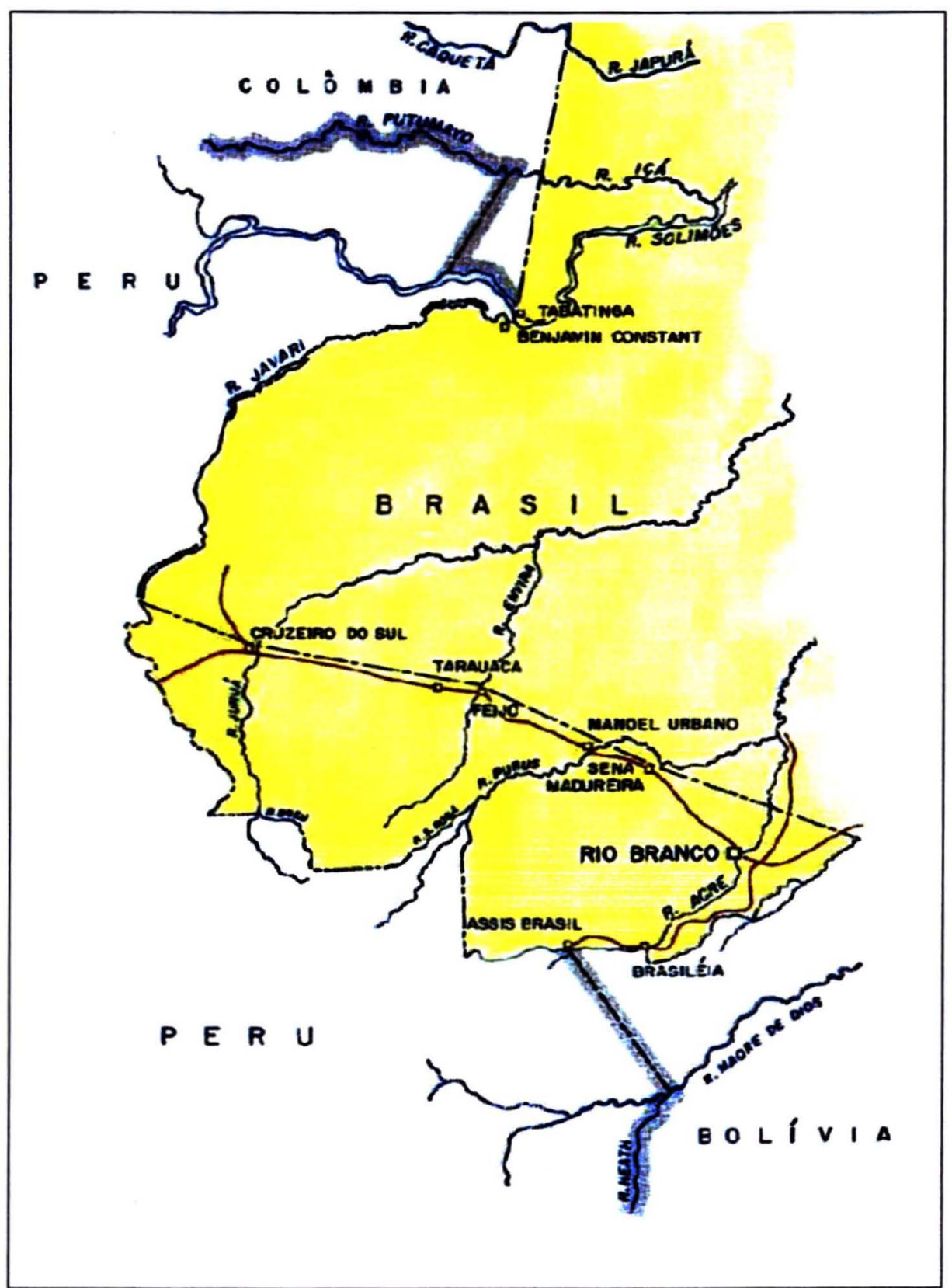

${ }^{6}$ Delimitada pelos Tratados de 1815 e 1909. Especificações fornecidas pelo Ministério das Relações do Exterior, Segunda Comissão Brasileira Demarcadora de Limites: http://www.scdl.gov.br ${ }^{7}$ http://info.Incc.br/wrmkkk/peesq.html 
Descrições demarcatórias ${ }^{8}$ :

I. A linha divisória entre o Brasil e a República do Peru, começa em frente à foz do Arroio Laverija, afluente da margem direita do rio Acre ou Aquiri, e sobe pelo álveo desse rio até a confluência dos seus dois ramos principais, continuando pelo mais setentrional, que é o seu principal formador, até à nascente.

II. Da nascente principal do rio Acre, segue por uma linha reta, no rumo verdadeiro de $53^{\circ} 33^{\prime} 47^{\prime}, 23 \mathrm{SW}$, até à interseção do paralelo de $11^{\circ} 00^{\prime} 00^{\prime \prime}, 00 \mathrm{~S}$ com o meridiano da nascente principal do rio Chambuiaco, afluente da margem direita do rio Purús.

III. Dessa interseção, prossegue, em direção Norte, pelo meridiano de $70^{\circ} 37^{\prime} 15^{\prime}, 18 \mathrm{~W}$ de Greenwich até a nascente principal do rio Chambuiaco.

IV. Da nascente principal do rio Chambuiaco, continua, águas abaixo, pelo álveo desse rio até a sua confluência com o rio Purús.

V. Pelo rio Purús, águas abaixo, até à boca do rio Santa Rosa ou Curinaá, seu afluente da margem esquerda.

VI. Pelo rio Santa Rosa, águas acima, até à sua nascente principal.

VII. Da nascente principal do Santa Rosa, segue por uma pequena reta, de 120 metros de comprimento, no rumo verdadeiro de $48^{\circ} 30^{\prime} \mathrm{NW}$, até encontrar o ponto mais próximo daquela nascente no "divortium aquarum" Embira-Purús.

VIII. Desse ponto, prossegue, pelo divisor de águas Embira-Purús, até a altura do paralelo de $10^{\circ} 00^{\prime} 00^{\prime \prime}, 00 \mathrm{~S}$.

IX. Continua a linha divisória para oeste, ajustada ao paralelo de $10^{\circ} 00^{\prime} 00^{\prime \prime}, 00 \mathrm{~S}$, até encontrar o divisor que separa as águas que correm para o rio Juruá, a oeste, das que vão para esse mesmo rio, ao Norte.

\footnotetext{
${ }^{8}$ http://info.Incc.br/wrmkkk/pedescr.html
} 
$X$. Desse último ponto, segue pelo divisor de águas do alto Juruá até à nascente principal do rio Breu, afluente da margem direita do Juruá.

XI. Da nascente principal do rio Breu, desce pelo álveo desse rio até a sua confluência com o rio Juruá.

XII. Da confluência do rio Breu com o rio Juruá, prossegue a linha divisória para Oeste, ajustada ao paralelo da foz do Breu $\left(09^{\circ} 24^{\prime} 42^{\prime}, 01\right.$ de latitude Sul), até encontrar o divisor de águas Ucaiale-Juruá.

XIII. Do encontro do paralelo de $09^{\circ} 24^{\prime} 42 ", 01 \mathrm{~S}$ com o divisor de águas Ucaiale-Juruá, segue, em direção geral Norte, pelo mesmo divisor de águas, até a nascente principal do rio Jaquirana ou Alto Javarí, passando antes pelo ponto mais ocidental do Brasil, situado nas proximidades da nascente do rio Môa.

XIV. Da nascente principal do rio Javarí, desce pela meia distância entre as margens desse rio até a sua boca, no rio Solimões ou Amazonas.

$\mathrm{XV}$. Da boca do rio Javari com o rio Solimões, águas acima, até a interseção do talvegue do rio Solimões ou Amazonas com o paralelo da boca do Igarapé Santo Antonio.

XVI. Ponto de Trijunção (Brasil-Peru-Colômbia), defronte às localidades de Tabatinaga (brasileira) e Letícia (colombiana). 


\subsubsection{Fronteira Brasil-Colômbia ${ }^{9}$}

Figura 3 - Brasil-Colômbia ${ }^{10}$ :

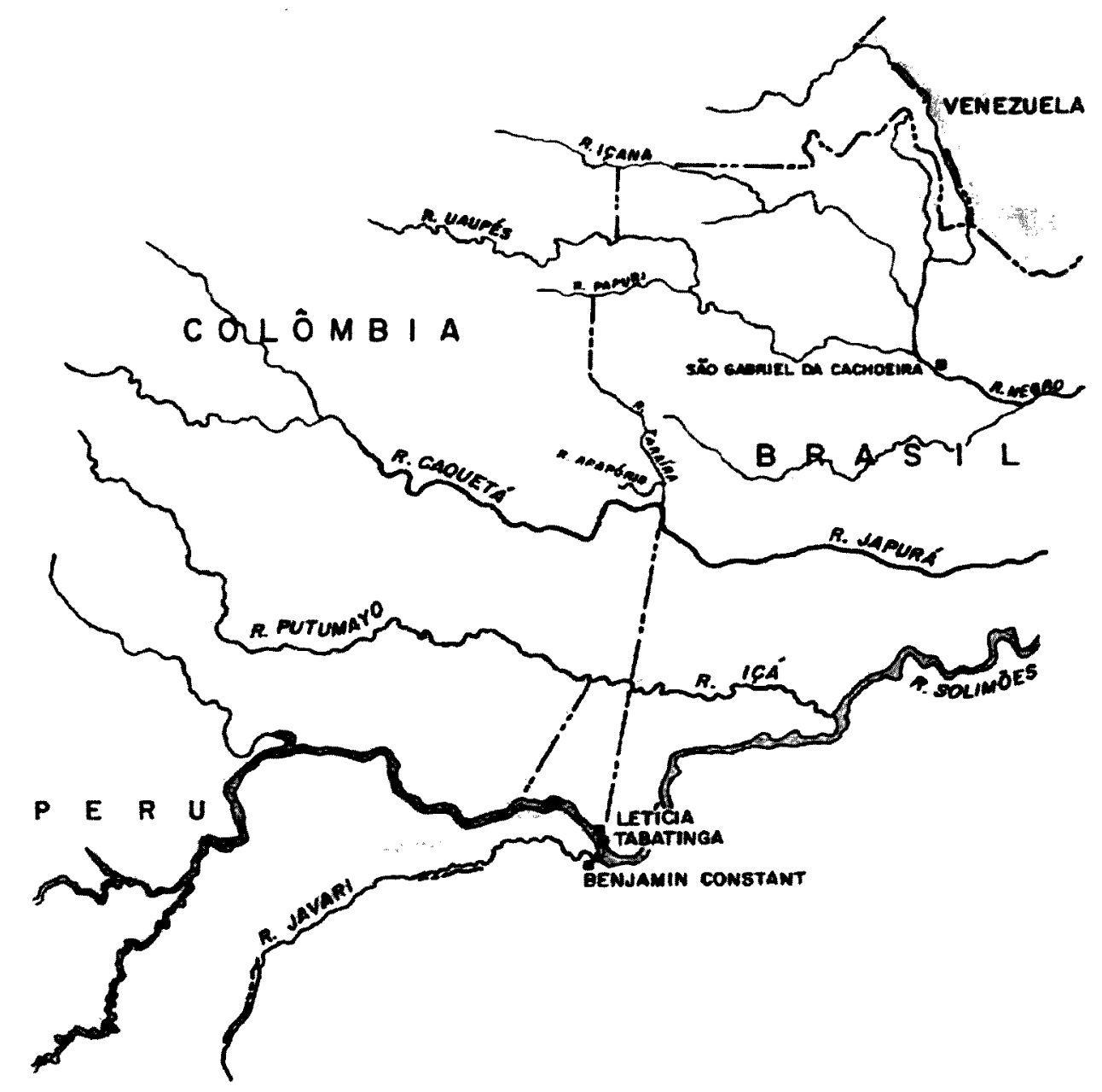

Descrições demarcatórias ${ }^{11}$ :

I. A linha divisória entre o Brasil e a República da Colômbia começa na interseç̧ão do talvegue do rio Solimões ou Amazonas com o paralelo da boca do Igarapé Santo Antônio (defronte às localidades de Letícia e Tabatinga), e segue, para Leste, ajustada a esse paralelo, até a dita boca.

\footnotetext{
${ }^{9}$ Delimitada pelos Tratados de 1907 e 1928. Especificações fornecidas pelo Ministério das Relações do Exterior, Segunda Comissão Brasileira Demarcadora de Limites: http://www.scdl.gov.br ${ }^{10} \mathrm{http}: / /$ info.Incc.br/wrmkkk/coesq.html

${ }^{11}$ http://info.Incc.br/wrmkkk/codescr.html
} 
II. Continua pelo leito desse igarapé (que corre entre as localidades de Letícia e Tabatinga) até a sua cabeceira.

III. Da cabeceira do Igarapé Santo Antônio, o limite segue por uma grande linha geodésica (mais de 300 quilômetros), TabatingaApapóris, na direção da boca do Apapóris (no rio Japurá), até o ponto de sua interseção com o talvegue do rio Japurá ou Caquetá (Cruzando neste trecho o Igarapé Belém, o rio Içá e o rios Purui e Ayo)

IV. Do ponto de intersecção da linha geodésica Tabatinga-Apapóris com o talvegue do rio Japurá, a linha divisória sobe por esse talvegue até à boca do rio Apapóris, em frente à Vila Bittencourt, situada em território brasileiro.

V. Da boca do Apapóris, prossegue pelo talvegue desse rio até a foz do Taraira, afluente de sua margem esquerda.

VI. Da desembocadura do rio Taraíra continua, águas acima, pela mediana desse rio, até a sua cabeceira principal.

VII. Da cabeceira principal do Taraíra, segue em direção Norte, pelo meridiano dessa cabeceira (cruzando o rio Tiquié), até encontrar a linha de meia distância entre as margens do rio Papuri, junto à localidade de Melo Franco, situada em território brasileiro (na margem direita desse rio).

VIII. Da intersecção do meridiano da cabeceira do rio Taraíra com o rio Papurí, continua, águas abaixo, pela mediana deste último rio, até a sua confluência com o Uaupés, próximo à localidade de Iauaretê, situada em território brasileiro (um pouco a jusante, na margem esquerda desse rio).

IX. Da desembocadura do Papuri, sobe pela linha de meia distância entre as margens do rio Uaupés, até a foz do Querari, que lhe entra pela margem esquerda.

$X$. Dessa confluência, prossegue, em direção Norte, pelo meridiano da foz do Querari, até encontrar o rio Içana. 
XI. Pela mediana do rio Içana, águas abaixo, até a sua intersecção com o paralelo da boca do rio Pégua.

XII. Ajustada a esse paralelo, segue para Leste até a sua intersecção com a linha de meia distância entre as margens do Cuiari.

XIII. Dessa intersecção, sobe a linha divisória pela mediana do rio Cuiari até o seu encontro com a mediana do rio Ianá.

XIV. Dessa confluência, continua, águas acima, pela linha de meia distância entre as margens do rio Ianá, até a foz do Igarapé Major Pimentel (braço mais oriental dos dois formadores do Ianá) e, pelo curso desse igarapé, até o marco situado entre as nascentes do mesmo igarapé e as do seu contravertente, o rio Memachi.

$\mathrm{XV}$. A partir desse marco, continua pelo divisor de águas entre as bacias do rio Negro e seu afluente Xié, passando pelo Cerro Caparro e entre as nascentes do rio Tomo e do Igarapé Jeju (este afluente do Xié), até alcançar o marco da cabeceira do rio Macacuni, cujo curso se desenvolve todo em território colombiano.

XVI. A partir do marco da cabeceira do Macacuni, o limite é constituído por uma linha geodésica (de 26.683 metros), que no azimute $74^{\circ} 56^{\prime} 17^{\prime \prime}$ alcança o marco da margem direita do rio Negro, em frente à ilha colombiana São José.

XVII. Desse marco, por uma linha reta, no azimute $128^{\circ} 53^{\prime} 37^{\prime \prime}$, até a intersecção com o talvegue deste rio Negro (ponto tripartite Brasil-Colômbia-Venezuela). 


\subsubsection{Fronteira Brasil-Venezuela ${ }^{12}$}

Figura 4 - Brasil-Venezuela ${ }^{13}$ :

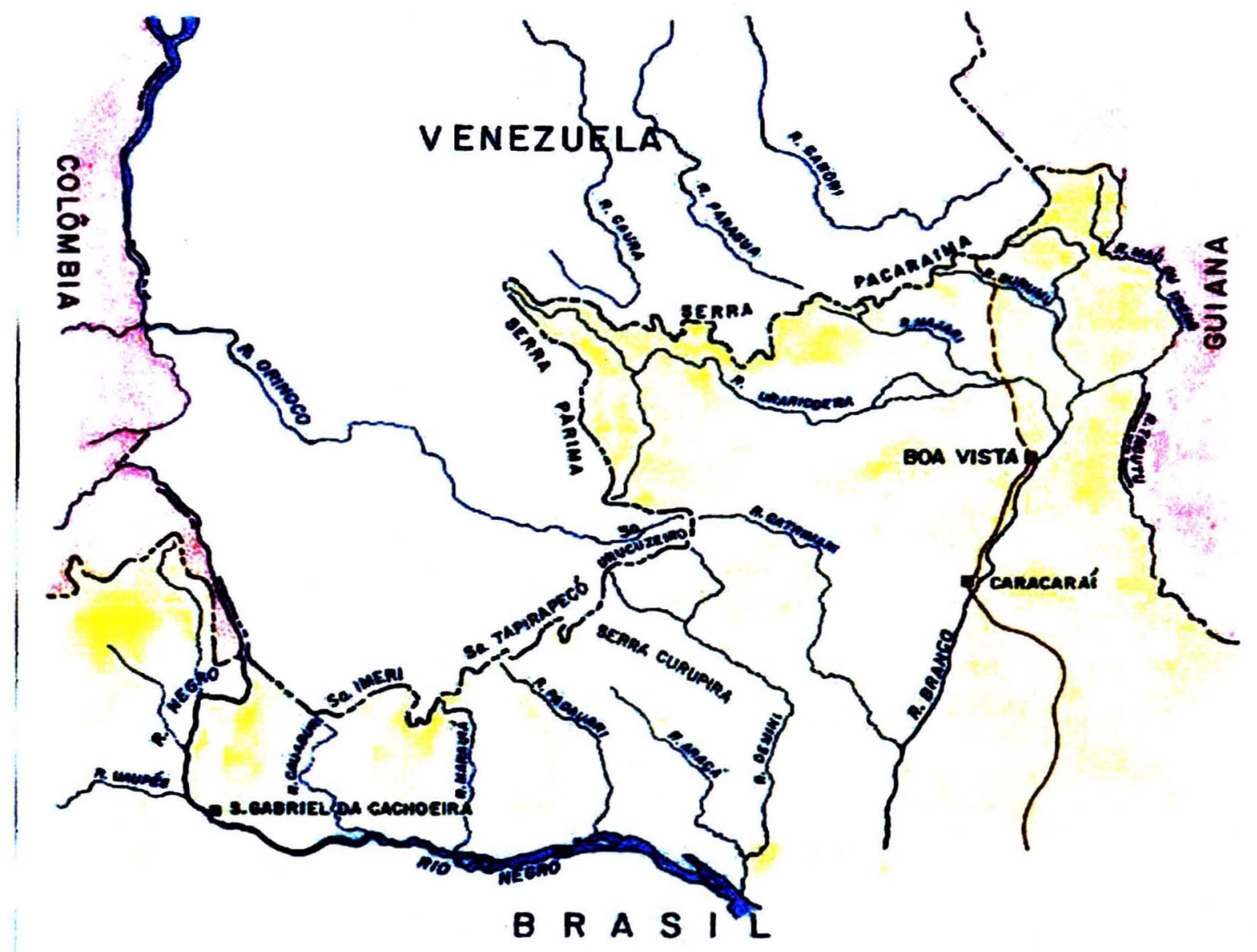

Descrições demarcatórias ${ }^{14}$ :

I. A linha divisória entre o Brasil e a Venezuela começa no ponto de trijunção das fronteiras Brasil-Colômbia-Venezuela, no talvegue do rio Negro, e segue por uma reta de aproximadamente $80 \mathrm{~km}$, no sentido sudeste, até o Salto Huá no canal de Maturacá (esta linha geodésica é chamada de Cucuí-Huá).

\footnotetext{
12 Delimitada pelo Tratado de 1859 e pelo Protocolo de 1928. Especificações fornecidas pelo Ministério das Relaçø̃es do Exterior, Segunda Comissão Brasileira Demarcadora de Limites: http://www.scdl.gov.br

${ }_{13}^{13}$ http://info.Incc.br/wrmkkk/veesq.html

${ }^{14}$ http://info.Incc.br/wrmkkk/vedescr.html
} 
II. Do Salto Huá, segue por uma reta de aproximadamente $12 \mathrm{~km}$, no sentido nordeste, até o Cerro Cupi (esta linha geodésica é chamada de Huá-Cupi). Do Cerro Cupi, segue pelo "divortium aquarum" entre a bacia do Amazonas e do Orinoco, passando inicialmente pela Serra da Neblina (cortando pelo norte o pico da Neblina, ponto mais elevado do Brasil) e pelas serras Imeri, Tapirapecó, Curupira, Urucuzeiro, Parima, Auari Urutanin e Pacaraima, até o marco de trijunção das fronteiras Brasil Venezuela - Guiana, no Monte Roraima, percorrendo neste trecho mais de $2000 \mathrm{~km}$.

\subsubsection{Fronteira Brasil-Guiana ${ }^{15}$}

Figura 5-Brasil-Guiana ${ }^{16}$ :

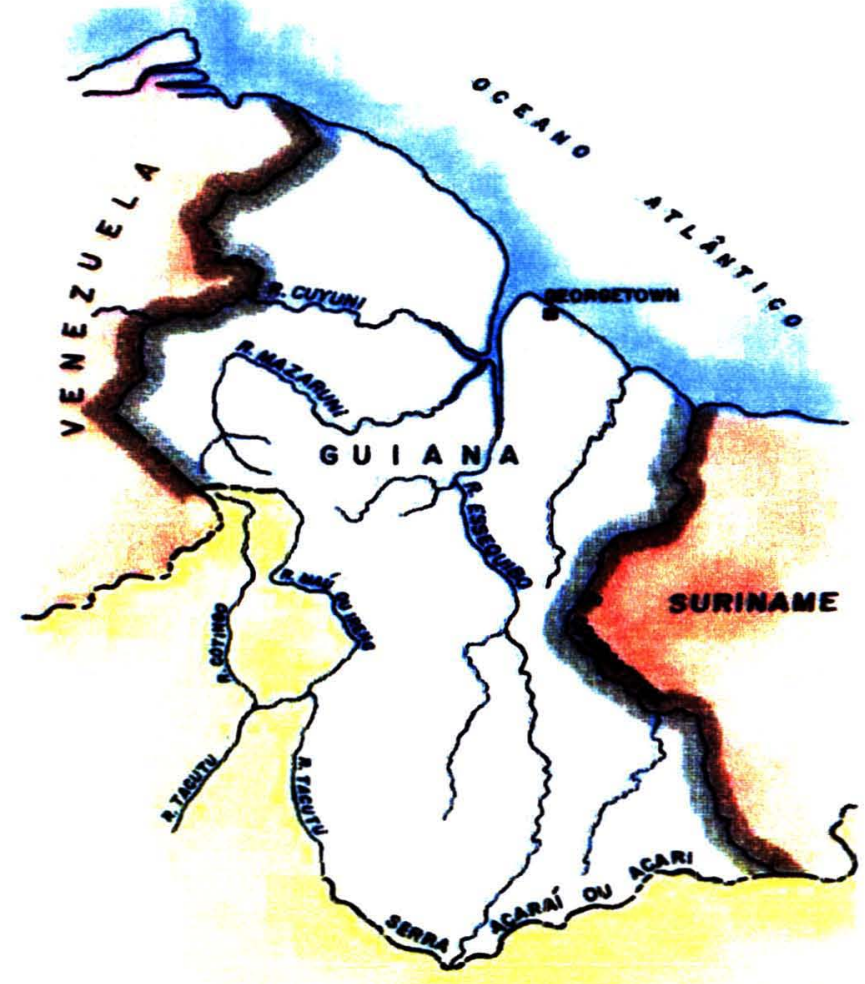

B $\quad R \quad A \quad S \quad I L$

15 Delimitada pelo Tratado de 1926. Especificações fornecidas pelo Ministério das Relações do Exterior, Segunda Comissão Brasileira Demarcadora de Limites: http://www.scdl.gov.br

${ }^{16} \mathrm{http}: / /$ info.Incc.br/wrmkkk/guesq.html 
Descrições demarcatórias ${ }^{17}$ :

I. A fronteira entre o Brasil e a República Cooperativa da Guiana tem início no ponto tríplice Brasil-Guiana-Venezuela, nos montes Roraima, entre as cabeceiras dos rios Cotingo e Arabopo, segue para nordeste, passando entre o Salto Paikwa, ao norte, e as quedas do Cotingo, que corre ao sul, em território brasileiro, continuando até o monte Yacontipu. Do monte Yakontipu, a fronteira segue na direção leste pela linha divisória das águas de diversos rios que, no norte correm em território Guiano, afluentes do rio Mazaruni e no sul correm para o rio Cotingo; até a nascente do rio Mau (ou Ireng). Neste trecho foram construídos 15 marcos.

II. Desce para o sul, por esse rio, até a sua confluência com o Tacutú, que, vindo do sul para o norte, inflete para a esquerda entrando à oeste em território brasileiro. Neste trecho foram construídos 12 marcos.

III. Continua em direção sul, subindo pelo rio Tacutú até a sua nascente, tendo sido construídos 18 marcos neste trecho.

IV. Da nascente do Tacutu, continua a fronteira pela linha divisória das águas entre a bacia do Amazonas (para o lado do Brasil) e as bacias do Essequibo e do Corentyne (para o lado da Guiana), até o ponto de convergência desta fronteira com a froteira do Suriname. Neste trecho foram construídos 89 marcos.

${ }^{17}$ http://info.Incc.br/wrmkkk/gudescr.html 


\subsubsection{Fronteira Brasil-Suriname ${ }^{18}$}

Figura 6 - Brasil-Suriname ${ }^{19}$ :

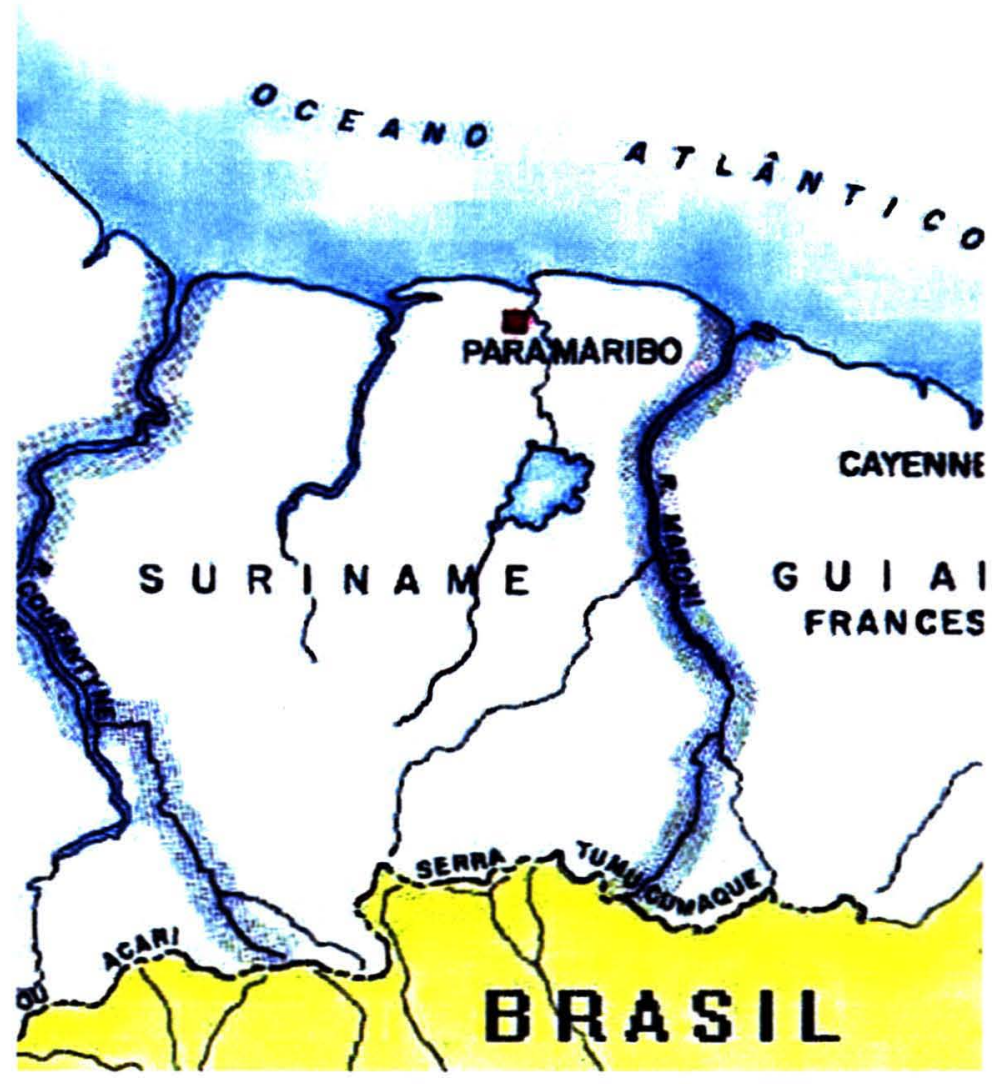

Descrições demarcatórias ${ }^{20}$ :

I. A linha de limites entre o Brasil e o Suriname, inicia-se no ponto de trijunção das fronteiras Brasil-Suriname-Guiana (na Serra de Tumucumaque), situado entre as cabeceiras dos rios Uanamú (no Brasil) e Kutarí (fronteira entre o Suriname e a Guiana).

\footnotetext{
${ }^{18}$ Delimitada pelo Tratado de 1906. Especificações fornecidas pelo Ministério das Relações do Exterior, Segunda Comissão Brasileira Demarcadora de Limites: http://www.scdl.gov.br

${ }^{19} \mathrm{http}$ ://info.Incc.br/wrmkkk/suesq.html

${ }^{20} \mathrm{http}$ ://info.Incc.br/wrmkkk/sudescr.html
} 
II. Segue pelo mais alto do terreno (divisão das águas) que separam a bacia do Amazonas, ao sul das bacias dos cursos de água que fluem para o norte, para o Oceano Atlântico, até o ponto tríplice Brasil-Suriname-Guiana Francesa (ainda na Serra de Tumucumaque), situado este, entre as cabeceiras dos rios Mapaoni (no Brasil) e Litana (afluente do Mapaoni, fronteira entre o Suriname e a Guiana Francesa).

\subsubsection{Fronteira Brasil-Guiana Francesa ${ }^{21}$}

Figura 7 - Brasil-Guiana Francesa ${ }^{22}$ :

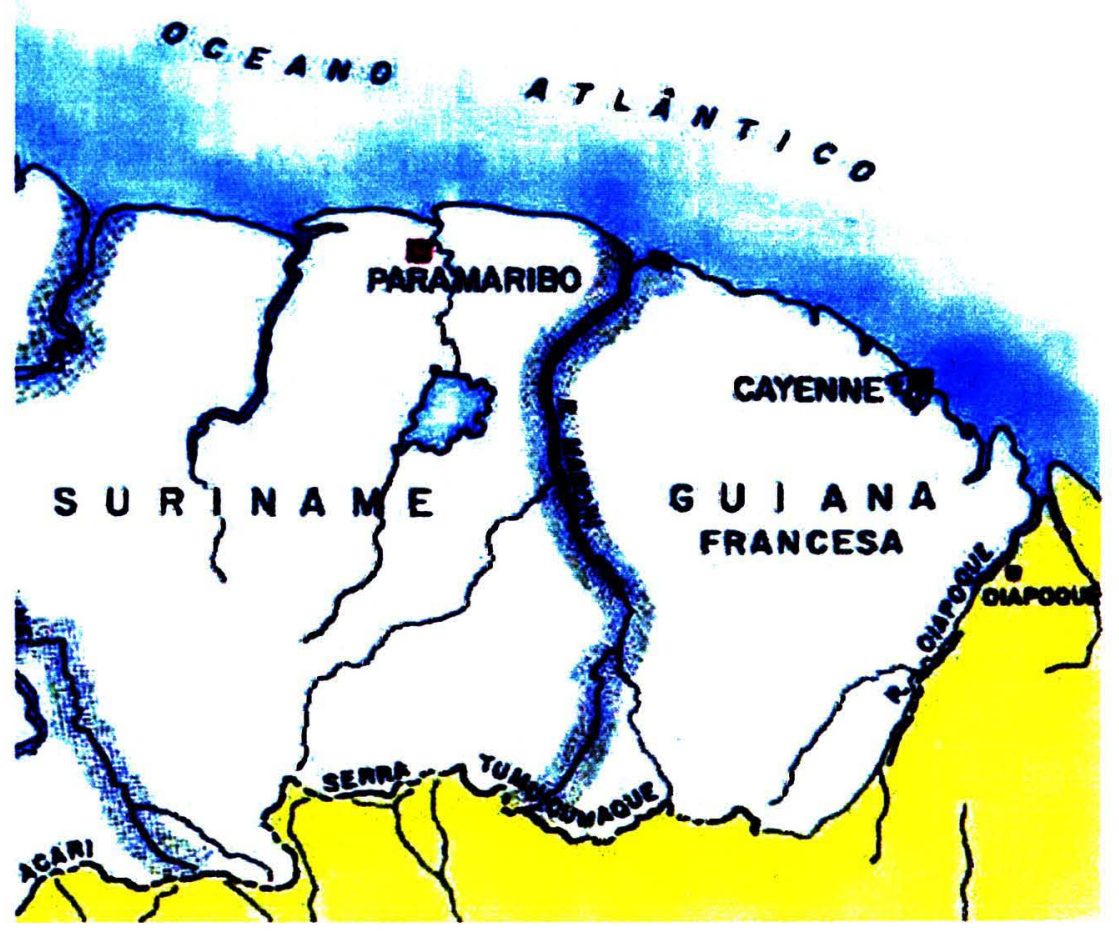

\footnotetext{
${ }^{21}$ Delimitada desde o Tratado de Utrecht de 1713, com interpretação dada pelo Laudo Arbitral de 1900. Especificações fornecidas pelo Ministério das Relações do Exterior, Segunda Comissão Brasileira Demarcadora de Limites: http://www.scdl.gov.br

${ }^{22}$ http://info.Incc.br/wrmkkk/guifres.html
} 
Descrições demarcatórias ${ }^{23}$ :

I. A fronteira entre o Brasil e o Departamento Ultramarino Francês da Guiana tem início no ponto tríplice entre o Brasil-Guiana Francesa-Suriname, na serra de Tumucumaque, seguindo para leste na direção desta cordilheira, pelo divisor das águas entre os rios Amazônicos e os cursos d'água que correm para o norte e para o Atlântico, até a nascente do rio Oiapoque. Ao longo deste divisor de águas existem sete marcos.

II. Considerando o rio Keriniutu como o formador principal do Oiapoque, segue a linha divisória pelo talvegue deste rio e do Oiapoque até a sua foz no Oceano Atlântico.

III. Na foz do Oiapoque, na continuação do talvegue deste rio, num ponto $\left(4^{\circ} 30^{\prime} 30^{\prime \prime} \mathrm{S} / 51^{\circ} 38^{\prime} 12^{\prime \prime} \mathrm{W}\right.$ ) na perpendicular ao alinhamento entre o Cabo Orange (no Brasil) e a Ponta de Coumarouman (na Guiana Francesa), inicia-se a Linha de Delimitação Maritima, que segue por uma loxodrômica no azimute $41^{\circ} 30^{\prime}$.

${ }^{23} \mathrm{http} / / /$ info.Incc.br/wrmkkk/guifrdes.html 


\subsubsection{Fronteira Brasil-Bolívia ${ }^{24}$}

Figura 8 - Brasil-Bolívia (Região Norte) ${ }^{25}$ :

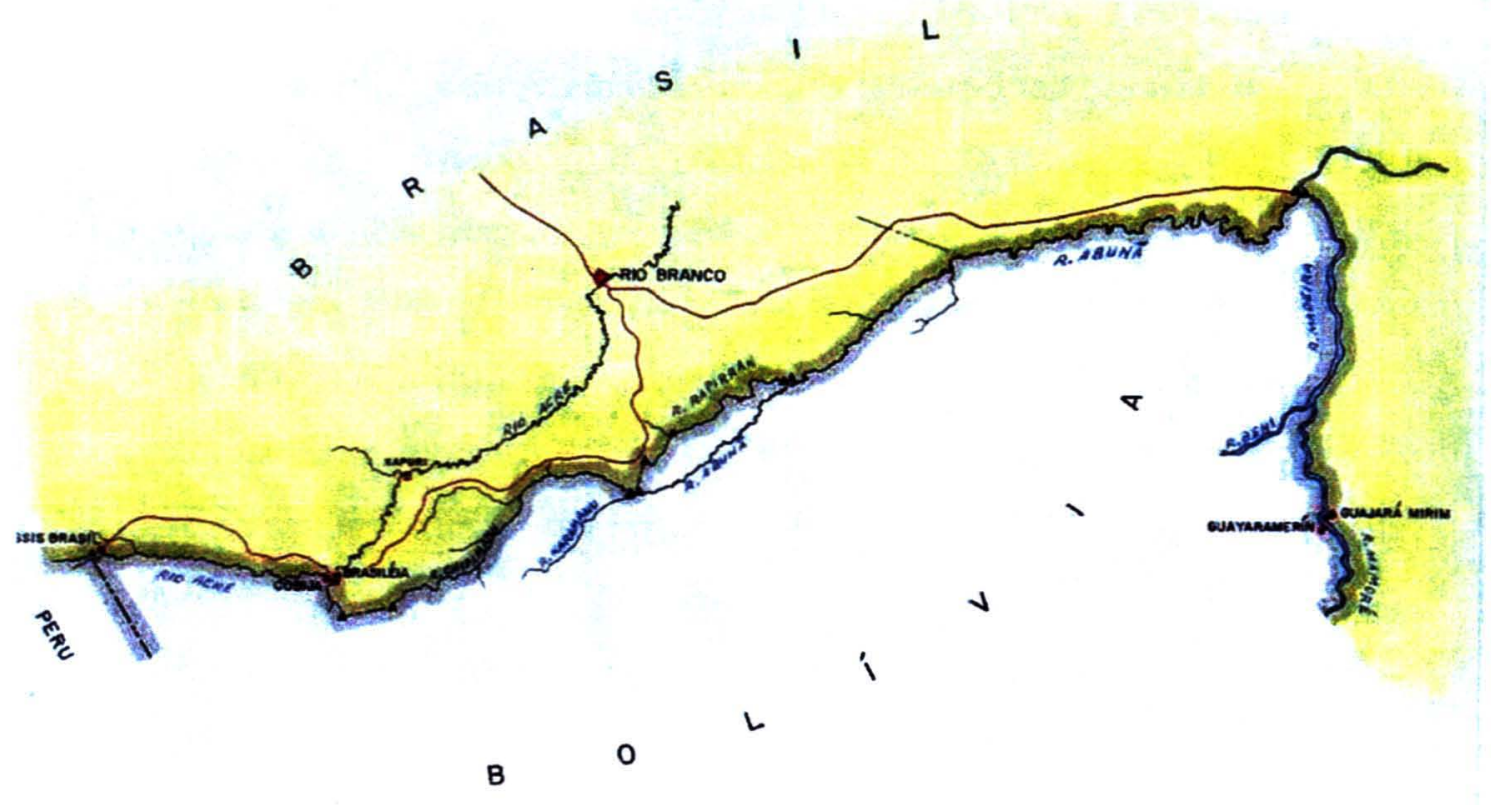

Descrições demarcatórias ${ }^{26}$ :

I. Este trecho da linha divisória inicia-se na confluência dos rios Mamoré e Beni, que se unem para formar o Madeira. Na região da confluência foram colocados, em 1914, seis Marcos de Referência, de ferro, sendo dois em Vila Murtinho (Brasil), e um em Villa Bella (Bolívia) e outro em Gran Cruz (Bolívia) - e ainda nas Ilhas da Confluência (BR) e Bolívar (BO). Deste ponto, a fronteira desce por mais 95 quilômetros pela linha de "meia distância" entre as margens, até a foz do rio Abunã.

\footnotetext{
24 Delimitada pelos Tratados de 1867, 1903, 1928 e Notas Reversais de Roboré de 1958. Especificações fornecidas pelo Ministério das Relações do Exterior, Segunda Comissão Brasileira Demarcadora de Limites: http://www.scdl.gov.br

${ }^{25} \mathrm{http}$ ://info.Incc.br/wrmkkk/bolivial.html

${ }^{26} \mathrm{http}: / /$ info.Incc.br/wrmkkk/bdescr 1.html
} 
II. Nesse trecho do rio são encontradas diversas ilhas e ilhotas, das quais as principais são: do Brasil, além da Ilha da Confluência (que tem marco), as ilhas Marinha, 15 de Novembro, Seis de Agosto, Misericórdia e 7 de Setembro; da Bolívia, além da Ilha Bolivar (que tem marco), as ilhas Sucre, Ribeirão, Amizade e Colombo. Na foz do Abunã foram colocados, no lado brasileiro e boliviano, dois Marcos de Referência.

III. Segue a linha divisória, subindo pelo "álveo" do rio Abunã por mais 403 quilômetros, até um ponto junto à cidade brasileira de Plácido de Castro, onde foram construídos dois marcos de referência, na margem esquerda deste rio, para assinalar, junto à foz do rio Rapirrãn o ponto onde a divisa deixa o Abunã e passa a subir pelo Rapirrãn.

IV. Pelo rio Rapirrãn segue a linha de fronteira pelo "álveo" deste rio por mais 101 quilômetros, até a sua nascente, passando pelo "Passo S. Francisco", onde foram colocados dois marcos de referência, um na margem brasileira e outro na margem boliviana. $\mathrm{Na}$ nascente deste rio foi construído o Marco Principal "Nascente do Rapirrãn".

V. Do Marco Principal da Nascente do Rapirrãn corre a linha divisória para sudoeste por uma reta de 12,1 quilômetros, até a Foz do Chipamano. Este setor está caracterizado por sete marcos secundários.

VI. Na foz do Chipamanu, que neste local se junta ao rio Karamanu (boliviano), para formar o rio Abunã, foram construídos dois Marcos de Referência, um na margem esquerda, brasileiro, e um no meio da confluência, boliviano. Segue agora a linha divisória pelo rio Chipamanu, por mais 187 quilômetros, até a sua nascente, onde foi construído o Marco Principal "Nascente do Chipamanu". 
VII. Do Marco Principal da Nascente do Chipamanu, corre a linha divisória aproximadamente para oeste, por uma reta de 19,2 quilômetros, até a Nascente do Igarapé Bahia, onde foi construído o Marco Principal "Nascente do Igarapé Bahia". Este setor está caracterizado por doze marcos.

VIII. Da Nascente do Igarapé Bahia, segue a linha divisória por este igarapé, por mais 20 quilômetros, até a sua foz no rio Acre, passando pela confluência dos dois galhos formadores do igarapé, onde foram construídos dois Marcos de Referência: um na margem brasileira (lado direito do "Braço Oriental") e outro na margem boliviana.

IX. Na foz do igarapé Baia, encontramos as cidades brasileiras de Epitaciolàndia (na margem direita do rio Acre e do igarapé Bahia) e Brasiléia (na margem esquerda do rio Acre). Aí, encontramos também, na margem direita do rio Acre e esquerda do igarapé Bahia, a cidade boliviana de Cobija, capital do Departamento de Pando. Nesta região foram construídos três marcos de referência, respectivamente: "Marco Principal de Referência de Epitaciolândia", "de Brasiléia" e "de Cobija".

$\mathrm{X}$. Segue a linha divisória subindo pelo "álveo" do rio Acre até o ponto tripartite Brasil-Bolivia-Peru, definido como um ponto no leito do rio Acre, correspondente ao prolongamento do curso do arroio Yaverija, que deságua pela sua margem direita. Este ponto fica um pouco a montante da cidade brasileira de Assis Brasil, onde foi construído um Marco Principal de Referência. Nesta região, encontramos também, na margem direita do rio Acre e do Yavarija, a localidade boliviana de Paraguassu, assim como, à direita do rio Acre e a esquerda do Yavarija, a localidade peruana de Inapori. 
XI. A partir da foz do rio Verde no Guaporé, a linha divisória entre a República Federativa do Brasil e a República da Bolívia segue descendo pelo "meio" do rio Guaporé por cerca de 962 quilômetros, até a foz deste rio no rio Mamoré. Não existem marcos construídos neste trecho da fronteira e as ilhas existentes não foram ainda adjudicadas ao Brasil e à Bolívia. Neste trecho da fronteira, bastante desabitado, encontramos apenas as localidades de Pimenteira e Costa Marques, no lado brasileiro.

XII. Da foz do rio Guaporé no Mamoré, segue a linha divisória descendo pelo "meio" do rio Mamoré por mais 245 quilômetros, até a confluência deste com o rio Beni, que vem da Bolívia. Desta confluência, o curso d'água passa a se denominar rio Madeira. Também não existem marcos construídos neste trecho, e as ilhas, também, ainda não foram adjudicadas. $\mathrm{Na}$ parte final do curso navegável destes rios de Extrema, Guaporé e Mamoré, encontramos as cidades de Guajará-Mirim, no Brasil e Guayaramerin no lado Boliviano. Destas localidades para o norte, todo o curso de águas, no rio Madeira, não permite a navegação.

XIII. A linha divisória entre a República Federativa do Brasil e a República da Bolívia, tem início no Ponto Tripartite BrasilBolivia-Paraguai, localizado imediatamente a jusante do Desaguadouro da Baia Negra no rio Paraguai, e segue subindo este rio por cerca de $47 \mathrm{~km}$, até um ponto localizado aproximadamente a nove quilômetros ao sul do Forte Coimbra, defronte ao Marco Principal denominado "Rio Paraguai", erigido na margem direita do dito rio. As ilhas existentes neste trecho não foram ainda adjudicadas nem ao Brasil nem à Bolívia. 
Figura 9 - Brasil-Bolívia (Região Central) ${ }^{27}$ :

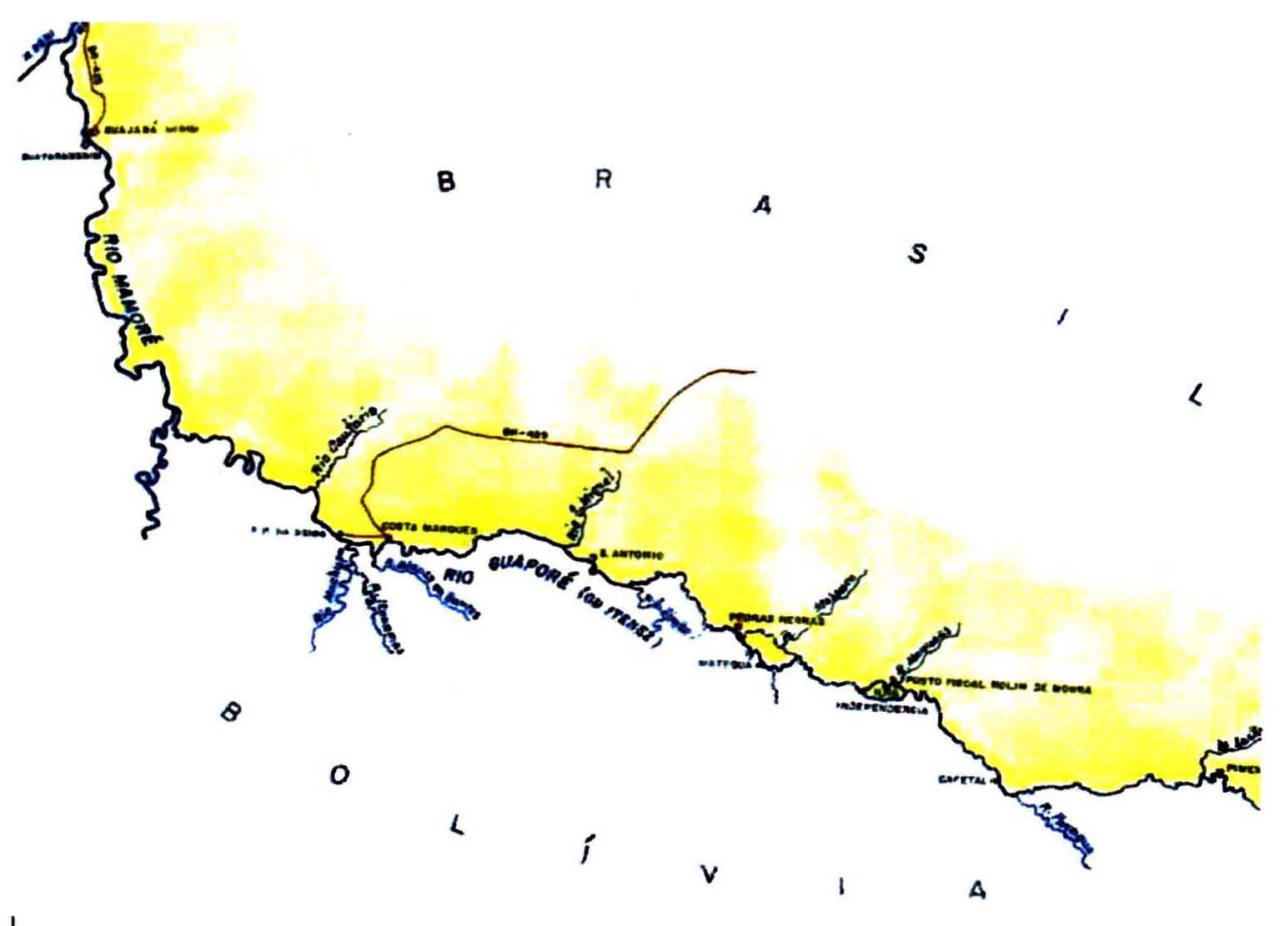

Descrições demarcatórias ${ }^{28}$ :

I. A partir desse ponto, a linha divisória se afasta do rio Paraguai e segue numa reta de $37,0 \mathrm{~km}$ para noroeste, até o Marco Principal "Baia Negra". Este setor, de terreno muito alagadiço, está caracterizado por três marcos secundários.

II. Do Marco Principal Baia Negra, segue a linha divisória por outra reta de 88,2 km para nordeste, até o Marco Principal "Taquaral", passando sobre a Morraria do Jacadigo (marco K-67.6) e próximo às comunidades bolivianas de San Pedrito (marco K-75.8) e El Carmem (marco K-80.0). Este setor está caracterizado por nove marcos secundários. Do Marco Principal Taquaral, vai a linha divisória para leste, sensivelmente sobre o paralelo de $19^{\circ} 02^{\prime}$, até encontrar o arroio Conceição, passando, ao chegar ao arroio, pelo Marco Principal "Conceição". 
III. Este setor, com $7,3 \mathrm{~km}$, corre pelos fundos do assentamento fundiário brasileiro denominado "Tamarineiro" e está caracterizado por quatro marcos secundários.

IV. Desse último marco desce a linha divisória por aproximadamente $3,2 \mathrm{~km}$, pelo meio do arroio, até sua foz no Canal do Tamengo. Este trecho, que cruza a estrada de ferro Brasil-Bolívia e a estrada de rodagem que liga as cidades de Corumbá e Puerto Suarez, está assinalado por um par de marcos de referência junto ao pontilhão da estrada de rodagem (marcos "Passo do Arroio Conceição") e mais um par de marcos de referência na foz do arroio (marcos "Foz do Arroio Conceição").

V. Prossegue a linha divisória pelo meio do Canal do Tamengo, seguindo por cerca de $6,4 \mathrm{~km}$ até um ponto próximo à entrada da Lagoa de Cáceres, na altura da Base Naval Boliviana do Tamarineiro, que se encontra na margem sul do canal e defronte ao Marco Principal "Tamarineiro", erguido na margem norte do mesmo canal.

VI. A linha divisória abandona o Canal do Tamengo em direção norte, passando pelo Marco Principal Tamarineiro e seguindo por uma reta de $8,4 \mathrm{~km}$ até o marco Principal "Pimenteira". Este setor, de terreno muito alagadiço, está caracterizado por dois marcos secundários.

VII. Continua a linha divisória agora para oeste, ainda em terreno alagadiço, ao norte da lagoa de Cáceres, por uma reta de $4,9 \mathrm{~km}$, até o Marco Principal "Carandazal".

VIII. Do Marco Principal Carandazal, segue a linha divisória por outra reta de 76,1 km para nordeste, até o Marco Principal "Caraguatal", passando inicialmente por terreno alagadiço (até o marco K-52.4), depois por terreno firme próximo à Baia Vermelha (marco K-11.7) e finalmente pela Morraria de Santa Tereza (marcos K-6.5 e K-3.3). 
IX. O Marco Principal Caraguatal esta localizado pouco ao sul da Lagoa Mandioré. Este setor está caracterizado por vinte marcos secundários.

$X$. Segue agora a linha divisória para leste, por uma reta de $11,3 \mathrm{~km}$, até o canal que serve de desaguadouro da Lagoa Mandioré no rio Paraguai. Neste ponto, na margem brasileira, foi levantado o Marco Principal de Referência denominado "Bonfim". Este setor, de terreno acidentado, atravessa a Morraria de Santa Tereza e está caracterizado por sete marcos secundários.

XI. Do marco Bonfim, que assinala o extremo oriental da República da Bolívia, segue a linha divisória pelo meio do álveo do canal até atingir a Lagoa Mandioré, onde foi erigido o Marco Principal de Referência denominado "Desaguadouro da Mandioré", em território boliviano, um pouco a oeste do destacamento boliviano Mandioré. Este setor tem aproximadamente nove $\mathrm{km}$.

XII. Segue agora a linha divisória, por duas retas sucessivas, dividindo a Lagoa Mandioré em partes aproximadamente iguais. A primeira reta, para noroeste, tem extensão de $10,6 \mathrm{~km}$, até o ponto médio da lagoa; a segunda, para o norte, com 10.045 metros, passa a 50 metros a leste de uma pequena ilha boliviana, onde foi construído o Marco Principal de Referência "Ilha do Velho" e vai até o Marco Principal "Palmital", situado na parte norte da lagoa.

XIII. Do Marco Principal Palmital corre a linha divisória para noroeste por outra reta de $26,9 \mathrm{~km}$, em terra firme, até o Marco Principal "Pantanal". Este setor está caracterizado por dez marcos secundários. Segue agora a linha divisória para leste, por outra reta de 4,0 km, ao sul da Lagoa Gaíba, até o Marco Principal "Garapeira", em trecho caracterizado por um marco secundário.

XIV. Do Marco Principal Garapeira continua a linha divisória para o norte por outra reta de $2,2 \mathrm{~km}$, caracterizada também por um marco secundário, até o Marco Principal "Areião", localizado na margem sudeste da Lagoa Gaíba. 
XV. Prossegue a linha dividindo a Lagoa Gaíba em partes aproximadamente iguais, também através de duas retas. A primeira, para noroeste, com extensão de $5,5 \mathrm{~km}$, até o ponto médio da lagoa e a segunda para o norte, por mais $4,9 \mathrm{~km}$, até o ponto indicado pelo Marco Principal de Referência "Norte da Gaíba", localizado em território boliviano.

XVI. O Marco Principal de Referência Norte da Gaíba, está localizado junto à entrada do Canal Pedro II (rio Pando para a Bolívia). Segue a linha de limite subindo pelo meio deste canal, que liga as lagoas Gaiba e Uberaba, por uma distância de aproximadamente $30 \mathrm{~km}$, até sua outra boca na Lagoa Uberaba e continua dai para leste, cerca de $5 \mathrm{~km}$, pela margem sul da referida lagoa, até o local do antigo marco "Sul da Lagoa Uberaba", que está destruído. Este ponto é definido por um novo Marco Principal de Referência "Sul da Lagoa Uberaba", localizado em território brasileiro, a 56,8 metros a sudeste do anterior.

XVII. A linha divisória vai agora para noroeste cortando a Lagoa Uberaba, até o Marco Principal denominado "Colina dos Limites". Esta linha tem uma extensão de 19,0 km.

XVIII. Da Colina dos Limites segue a linha por outra reta de $10,9 \mathrm{~km}$ para sudoeste, passando pelo Marco Principal "Corixa Grande", situado na margem oriental dessa corixa, até o meio da mesma.

XIX. Desse ponto prossegue a linha divisória ao longo das corixas: Grande e do Destacamento, passando sucessivamente, pelos seguintes trechos (ou subsetores), balizados com marcos de numeração provisória:

Primeiro Subsetor (Linha sinuosa): Pelo meio do canal da Corixa Grande, cerca de $77 \mathrm{~km}$, passando pela Lagoa das Piranhas até o último marco construído na Campanha de 1955, denominado "Marco 28";

Segundo Subsetor: Do Marco 28 até o "Marco 27", situado ao sul da Baia Redonda, por uma reta de 3,4 km; 
Terceiro Subsetor (Linha sinuosa): Pelo meio dessa Baia, cerca de $2 \mathrm{~km}$, dividindo suas águas em partes equivalentes, até o "Marco 26", situado ao norte da mesma Baia Redonda;

Quarto Subsetor: Do marco 26 até o "Marco 25", situado na margem sul da Lagoa Orion, por uma reta de 2,5 km;

Quinto Subsetor (Linha sinuosa): Pelo meio dessa Lagoa, dividindo suas águas em partes equivalentes, e a seguir pelo meio da Corixa Grande, até o ponto denominado "Passo da Corixa", há dois marcos de referência de número 24, denominados "Passo da Fronteira", numa extensão de aproximadamente $44 \mathrm{~km}$;

Sexto Subsetor (Linha sinuosa): Desse ponto, segue o limite pelo meio da Corixa Grande, cerca de $28,2 \mathrm{~km}$, até o último marco construído na Campanha de 1954, denominado "Marco 23";

Sétimo Subsetor (Linha poligonal): A partir desse marco vai o limite por $34,0 \mathrm{~km}$, ao longo da Corixa Grande e, depois, da Corixa do Destacamento, por uma linha poligonal balizada por marcos de numeração sucessiva, decrescente, até o "Marco 2"; Oitavo Subsetor (Linha sinuosa): A partir desse marco vai o limite, por cerca de $2,4 \mathrm{~km}$, pelo meio da Corixa do Destacamento, até outro passo, há também dois Marcos de Referência, de número 1, denominados "Passo do Ferreiro"; Nono Subsetor (Linha sinuosa): Desse ponto, continua o limite pelo meio da Corixa do Destacamento, cerca de mais $3,8 \mathrm{~km}$ até a passagem da antiga estrada que unia o destacamento brasileiro à povoação boliviana de San Matias. Nesse ponto, dois Marcos de Referência denominados "Passo do Destacamento da Corixa". Prossegue a linha de limite subindo o leito da corixa por pouco mais de $1 \mathrm{~km}$, até o pontilhão na nova estrada que, vindo de Cáceres, no Brasil, segue para San Matias. Junto ao pontilhão, nas margens da corixa, dois Marcos de Referência, denominados "Novo Passo do Destacamento da Corixa". 
XX. Continua a linha, por uma centena de metros mais, pelo leito da corixa até sua nascente, ao sul de uma pequena colina, onde se encontra um reservatório de águas cristalinas, ladeado por um par de Marcos de Referência denominados "Cabeceira da Corixa do Destacamento" que têm a numeração K-32.5.

XXI. Da nascente da Corixa do Destacamento (assinalado pelo par de marcos K.32.5), segue a linha divisória por uma poligonal de 32,5 $\mathrm{km}$, cujos vértices são marcos secundários, numerados conforme as distâncias em quilômetros medidas a partir do Marco Principal São Matias, localizado a noroeste da localidade boliviana de San Matias.

XXII. Esta poligonal descreve um semicírculo passando por terreno firme até o Marco do Serrinho de S. Matias (entre os marcos K.15.6 e K.16.0), desce daí para terrenos mais baixos, entrando finalmente nos alagados que formam o início da Corixa Grande (marco K.8.8), continuando por esta corixa até o Marco Principal "São Matias" ou "Totora". Neste trecho encontramos trinta e quatro marcos secundários. 
Figura 10 - Brasil-Bolívia (Região Sul) ${ }^{29}$ :

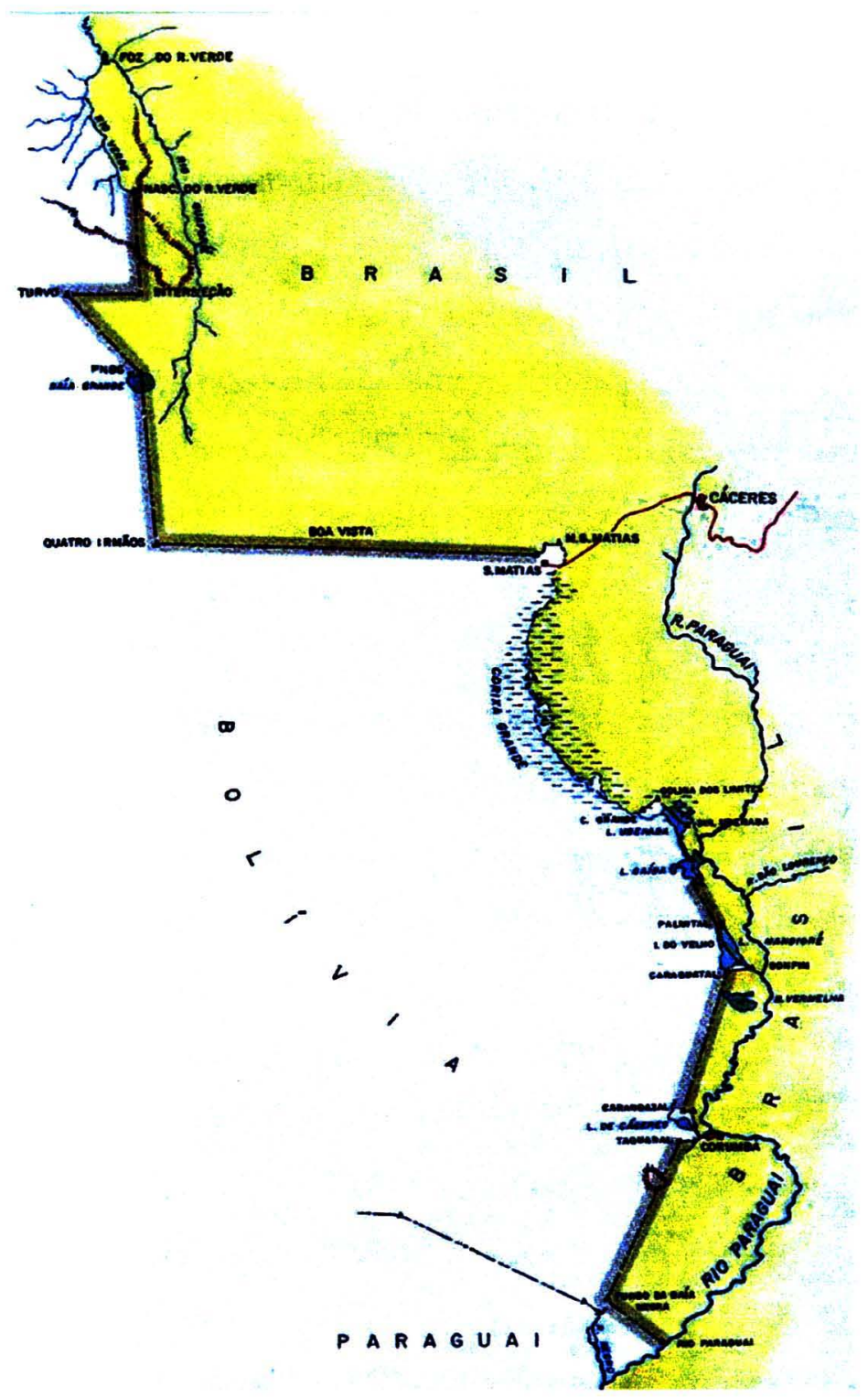

Descrições demarcatórias ${ }^{30}$ :

I. Do Marco Principal São Matias segue a linha divisória para oeste por $186,5 \mathrm{~km}$. Este trecho é formado por duas grandes retas, praticamente no mesmo alinhamento. 
II. A primeira, com 111,5 km, até o Marco Principal "Boa Vista", com vinte marcos secundários e a segunda, com $75,0 \mathrm{~km}$, até o Marco Principal "Quatro Irmãos", com mais quinze marcos secundários. Desse último Marco Principal, prossegue a linha divisória para o norte, numa reta de $88,0 \mathrm{~km}$, até o Marco Principal denominado "Norte da Baia Grande". Do Ponto Norte da Baia Grande (Lagoa Marfil), segue a linha divisória para noroeste até o Marco Principal "Turvo", por outra reta de 55,2 $\mathrm{km}$. Este trecho está caracterizado por treze marcos secundários.

III. Do Marco do Turvo segue a linha divisória para leste, acompanhando o Paralelo deste marco, por $35,6 \mathrm{~km}$, até um ponto definido como a interseção deste Paralelo com a linha geodésica que, partindo do Marco Principal "Quatro Irmãos", segue na direção da Nascente do rio Verde (determinada em 1909). Neste ponto foi erigido um Marco Principal denominado "Interseção". Este trecho está caracterizado por quinze marcos secundários. Desse Marco Principal de Interseção segue a linha divisória para o norte, por mais $52,8 \mathrm{~km}$, no alinhamento anteriormente definido pela geodésia que, partindo do Marco Principal "Quatro Irmãos", segue na direção da nascente do rio Verde (determinada em 1909). Este trecho está caracterizado por treze marcos secundários e se desenvolve em terreno baixo (até o marco $\mathrm{K}$ 14.9), subindo depois, abruptamente, a serra Ricardo Franco (marco K-23.0) e seguindo pela parte alta da serra até a citada nascente, denominada "Nascente do Rio Verde 1909".

IV. Desce a linha de fronteira pelo rio Verde, numa extensão de cerca de $121 \mathrm{~km}$, até a sua confluência com o rio Guaporé ou Itenez, onde foram erguidos dois Marcos de Referência: $\mathrm{O}$ brasileiro, na margem direita do rio Verde e esquerda do Guaporé e o marco boliviano, em frente, na margem esquerda do rio Verde e do Guaporé ou Itenez. Estes Marcos foram denominados "Foz do Rio Verde". 


\subsubsection{Fronteira Brasil-Paraguai ${ }^{31}$}

Figura 11 - Brasil-Paraguai ${ }^{32}$ :

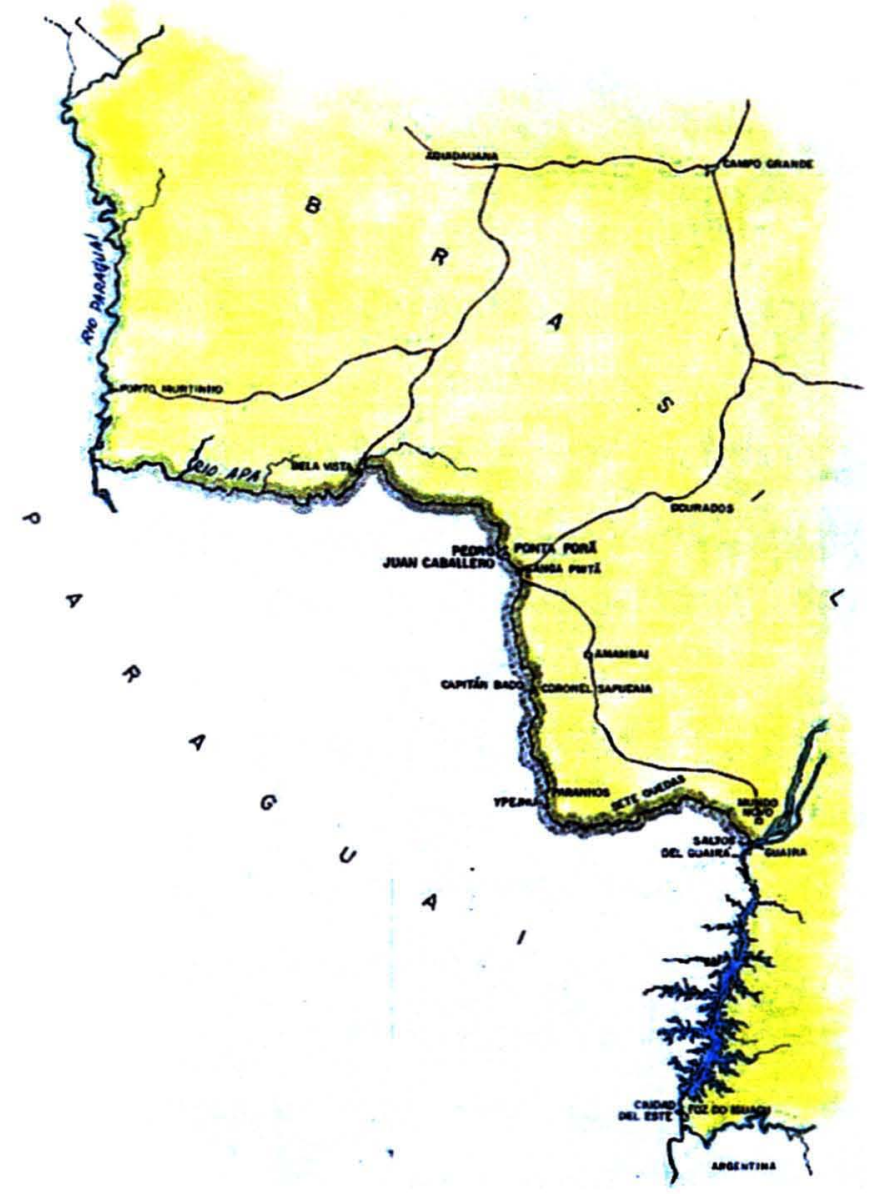

Descrições demarcatórias ${ }^{33}$ :

I. A linha de limite do Brasil com o Paraguai se inicia no encontro do talvegue do rio Iguaçu com o álveo do rio Paraná, pelo qual sobe até encontrar a barragem da Hidrelétrica de Itaipu. Neste trecho localizam-se as cidades de Foz do Iguaçu (Brasil) e Ciudad Del Este (Paraguai), ligadas pela "Ponte da Amizade".

\footnotetext{
${ }^{31}$ Delimitada pelo Tratado de 1872 e pelo Tratado Complementar de 1927. Especificações fornecidas pelo Ministério das Relações do Exterior, Segunda Comissão Brasileira Demarcadora de Limites: http://www.scdl.gov.br

${ }^{32} \mathrm{http}: / /$ info.Incc.br/wrmkkk/paesq.html

${ }^{33} \mathrm{http}: / /$ info.Incc.br/wrmkkk/padescr.html
} 
II. Prosseguindo, passa entre as turbinas 9 e 10 da referida Hidrelétrica e sobe pela projeção do antigo álveo daquele rio sobre o espelho d'água do Lago de Itaipu até a projeção, sobre o mesmo espelho d'água, do antigo Salto Grande das Sete Quedas.

III. Procura, então, o divisor de águas da serra de Maracaju, pelo qual vai até encontrar a Serra de Amambai. Neste trecho situam-se as cidades geminadas de Sete Quedas / Pindoti Porã, além das localidades de Vila Miguel / Gorra Puitã.

IV. Continua pelo divisor de águas da serra de Amambai até a nascente do arroio Estrela, formador do rio Apa, trecho em que se encontram as cidades gêmeas de Paranhos / Ype-Jhu, Coronel Sapucaia / Capitán Bado e Ponta-Porã / Pedro Juan Caballero, além das localidades de Sanga Puitã / Sanja Puitã e da cidade brasileira de Aral Moreira.

V. Desce pelo álveo do arroio Estrela e a seguir pelo do rio Apa, até sua foz no rio Paraguai, passando entre as cidades de Bela Vista (Brasil) e Bella Vista (Paraguai), unidas por uma ponte.

VI. A partir da confluência do rio Apa, a linha de limite é determinada pelo meio do canal principal do rio Paraguai, de maior profundidade, mais fácil e franca navegação, até finalizar na entrada ou desaguadouro da Baía Negra, no ponto tripartite Brasil-Paraguai-Bolívia.

VII. Neste último trecho, à margem do rio Paraguai, encontra-se a cidade brasileira de Porto Murtinho. 


\subsubsection{Fronteira Brasil-Argentina ${ }^{34}$}

Figura 12 - Brasil-Argentina ${ }^{35}$ :

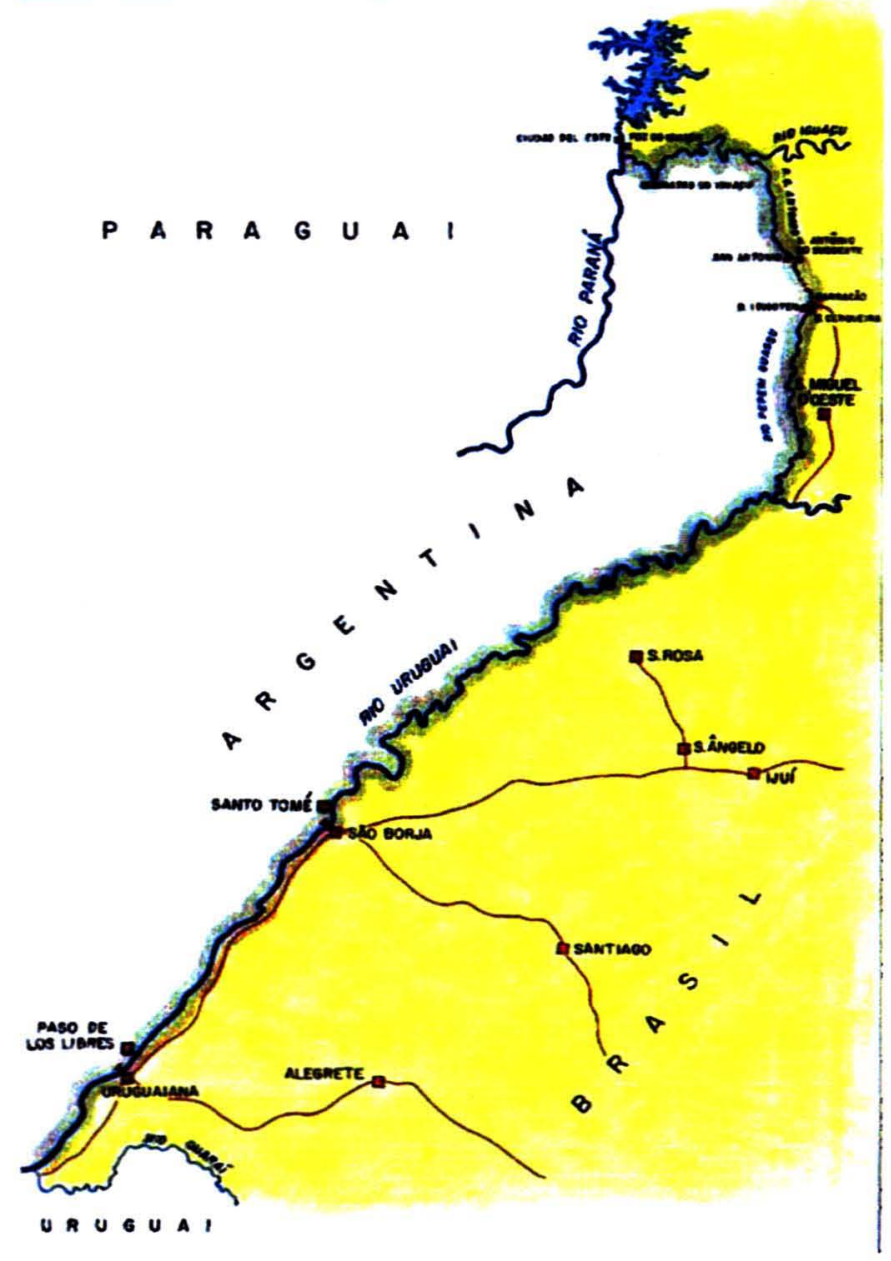

Descrições demarcatórias ${ }^{36}$ :

I. A linha de limites do Brasil com a Argentina se inicia no rio Uruguai, na interseção do canal navegável desse rio com a linha normal entre suas margens, que passa logo a jusante da ponta sudoeste da Ilha Brasileira, localizada na parte sul da barra do rio Quaraí.

\footnotetext{
${ }^{34}$ Delimitada pelo Tratado de 1898 , baseado no Laudo Arbitral de 1895 , complementado pela Convenção de 1927. Especificações fornecidas pelo Ministério das Relações do Exterior, Segunda Comissão Brasileira Demarcadora de Limites: http://www.scdl.gov.br

${ }^{35} \mathrm{http}: / /$ info.Incc.br/wrmkkk/aresq.html

${ }^{36} \mathrm{http} / / /$ info.Incc.br/wrmkkk/adescr.html
} 
II. Segue subindo o rio Uruguai pelo meio de seu canal navegável, passando entre sua margem direita (Argentina) e a mencionada Ilha Brasileira, até encontrar a linha que une o marco brasileiro da barra do rio Quarai, com seu confrontante argentino na margem direita do rio Uruguai.

III. Prossegue, pelo talvegue do rio Uruguai até a foz do rio PeperiGuassú. Ao longo deste curso, foram adjudicadas 24 ilhas para o Brasil e 29 ilhas para a Argentina.

IV. Da foz do Peperi-Guassu, continua a linha de divisa, águas acima, pelo álveo deste rio até sua nascente principal.

V. Da cabeceira principal do Peperi-Guassu, onde foi colocado um Marco Principal, na demarcação, segue a linha de divisa pelo mais alto do terreno, dividindo as águas que correm para o rio Uruguai, afluente do rio Paraná, das que correm para o lado do Brasil, para o rio Capanema, tributário do rio Iguaçu, até alcançar a nascente do rio Santo Antônio.

VI. Da cabeceira do rio Santo Antônio, onde também, por ocasião da demarcação foi colocado um Marco Principal, desce a linha de limite por este rio até a sua confluência com o rio Iguaçu.

VII. Da boca do rio Santo Antônio, vai o limite pelo talvegue do rio Iguaçu até sua desembocadura no rio Paraná, passando pelo Salto do Iguaçu, até onde se inicia a fronteira do Brasil com o Paraguai. 


\subsubsection{Fronteira Brasil-Uruguai ${ }^{37}$}

Figura 13 - Brasil-Uruguai ${ }^{38}$ :

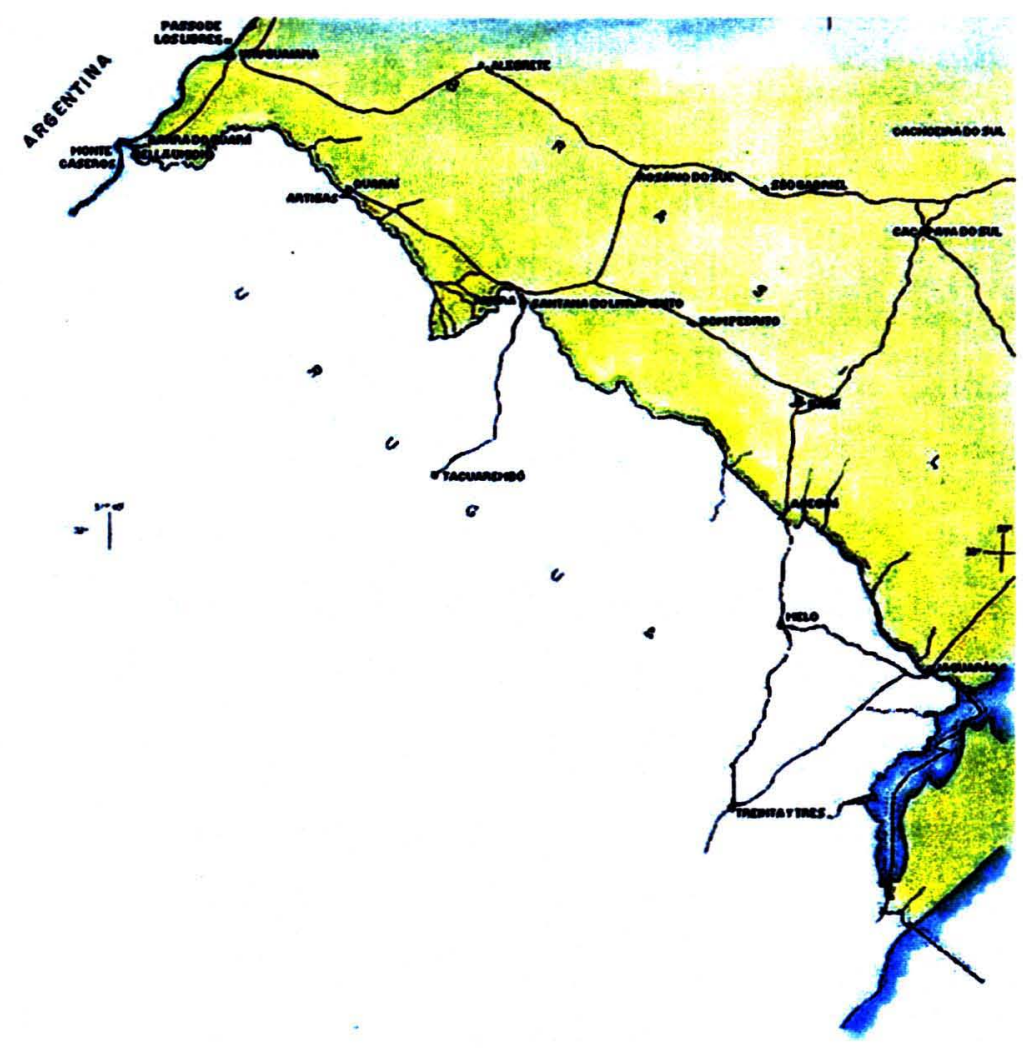

Descrições demarcatórias ${ }^{39}$ :

I. A linha divisória entre a República Federativa do Brasil e a República Oriental do Uruguai tem início na Barra do Arroio Chuí - fixada pelos molhes construídos no alinhamento da divisória lateral marítima (Azimute 128), a cerca de 750 metros a Este-Nordeste do Marco Principal (de referência) 1-P, localizado em território brasileiro e segue pelo álveo do citado arroio, numa distância aproximada de $13,0 \mathrm{~km}$, até o ponto imediatamente ao sul do Marco Principal 2-P, na região do antigo Passo Geral do Chuí.

\footnotetext{
${ }^{37}$ Delimitada pelos Tratados de 1851 e 1909. Especificações fornecidas pelo Ministério das Relações do Exterior, Segunda Comissão Brasileira Demarcadora de Limites: http://www.scdl.gov.br

${ }^{38} \mathrm{http}: / /$ info.Incc.br/wrmkkk/uesq.html

${ }^{39} \mathrm{http} / / /$ info.Incc.br/wrmkkk/udescr.html
} 
II. Nesse ponto, a linha divisória abandona o arroio, passa pelo Marco 2-P e dirige-se até o antigo Passo Geral do arroio São Miguel, seguindo uma reta de aproximadamente $8,7 \mathrm{~km}$ no sentido aproximado Este - Oeste. Este setor está caracterizado pelos seguintes marcos, além do 2-P acima citado: cinco marcos intermédios (nrs. 1-I até 5-I); os Marcos Principais 3-P/A e 3-P (este último anulado), ambos na margem direita do arroio São Miguel; e finalmente o Marco Principal (de referência) 3-P/B, na margem esquerda (uruguaia) do mesmo arroio. O marco 3-P foi anulado em decorrência da Convenção de 7 de maio de 1913, sendo substituido em 1916 pelos Marcos 3-P/A e 3-P/B acima mencionados, mas permanece em sua posição original, por disposição expressa dos dois governos.

III. Do ponto médio do arroio São Miguel, entre os marcos 3-P/A e 3P/B acima citados, desce a linha divisória pela meia distância entre as margens do arroio até a sua foz na Lagoa Mirim, no paralelo do Marco Principal (de referência) 4-P, localizado em território brasileiro, numa distância aproximada de 13,0 km. Apesar da linha divisória ser definida como a meia distância das margens, os dois países têm jurisdição comum sobre as águas do arroio São Miguel, conforme estabelece a Convenção de 1913.

IV. Da embocadura do arroio São Miguel, segue a linha divisória sucessivamente, pelos seguintes trechos (ou subsetores) da Lagoa Mirim:

Primeiro Subsetor (Linha de meias distâncias): Uma série de nove retas de diferentes rumos, tratadas entre pontos eqüidistantes das margens, até a altura da Ponta do Rabotieso, numa extensão de $86,8 \mathrm{~km}$;

Segundo Subsetor (Linha convencional quebrada): Uma seqüência de três retas, passando junto à ilha Taquari, até alcançar, na altura da Ponta Parobi (margem uruguaia), a linha de talvegue da lagoa, numa extensão de $20,6 \mathrm{~km}$; 
Terceiro Subsetor (Linha de talvegue): Trecho do talvegue do canal da lagoa, até interceptar a linha transversal que liga o ponto mais a leste da Ponta Muniz (margem uruguaia) ao extremo nordeste da Ponta dos Latinos ou do Fanfa (margem brasileira), numa extensão de $19,0 \mathrm{~km}$;

Quarto Subsetor (Linha reta convencional): Da interseção acima mencionada, uma linha reta até a boca do rio Jaguarão, numa extensão de $13,7 \mathrm{~km}$.

V. A linha divisória através da Lagoa Mirim, acima descrita, numa extensão total de $140,1 \mathrm{~km}$, deixa para a soberania brasileira a Ilha Grande de Taquari, e para a soberania uruguaia as ilhas Barra Del Cebollati, Confraternidad e Zanjon, e acha-se minuciosamente representada em Cartas da Fronteira firmadas pelos delegados de ambos os paises em 1916;

VI. Na boca do rio Jaguarão existem quatro marcos, dois na margem esquerda: os Marcos Principais (de referência) 5-P/A (Brasil) e 5$\mathrm{P}$ (este último anulado); e dois na margem direita: o Marco Principal (de referência) 5-P/A (Uruguai) e o marco intermédio 6I (anulado).

VII. O Marco Principal 5-P e o marco intermédio 6-I, foram anulados em decorrência do Tratado de 30 de outubro de 1909 e substituídos pelos Marcos Principais 5-P/A (Brasil) e 5-P/A (Uruguai), acima mencionados.

VIII. A partir da boca do rio Jaguarão, a linha divisória sobe pelo seu talvegue, numa distância aproximada de $32,4 \mathrm{~km}$, até a confluência do arroio Lagões, assinalada pelos marcos intermédios (de referência) 6-I/A (Brasil), na margem brasileira, e 6-I/A (Uruguai) na margem uruguaia.

IX. Neste setor, ficam sucessivamente, para a soberania de um e outro país, as ilhas a seguir relacionadas: 
Da Barra, das Ovelhas, da Areia e do Braulio (Brasil), Denis (Uruguai), Santa Rita ou Charqueada (Brasil), Jacinto (Uruguai), do Braz (Brasil), Socorro (Uruguai) e do Moinho (Brasil).

$\mathrm{X}$. Prossegue a linha divisória pelo rio Jaguarão águas acima, cerca de $120,0 \mathrm{~km}$, em regime de meia distância entre as margens, até a desembocadura do rio Jaguarão-Chico ou Guabiju, assinalada em uma e outra margem pelos Marcos Principais 6-P (Brasil) e 6-P (Uruguai).

XI. Abandonando o rio Jaguarão, segue a linha divisória pela meia distância entre as margens do rio Jaguarão-Chico ou Guabiju, cerca de $18,5 \mathrm{~km}$, até a foz do arroio da Mina, assinalada pelos Marcos Principais (de referência) 7-P (Brasil) e 7-P (Uruguai).

XII. Continua a linha divisória agora pelo álveo do arroio da Mina, na distância aproximada de $20,4 \mathrm{~km}$, até suas vertentes no Cerro de Acegua. Ao longo desse trecho encontram-se os marcos intermédios (de referência) 7-I (Brasil) e 7-I (Uruguai), no Passo do Arroio da Mina; 8-I (Brasil) e 8-I (Uruguai), junto à confluência do arroio Concórdia; bem como oito marcos reduzidos na região da nascente do arroio da Mina: 8-I/A (Brasil), 8-V/A (Uruguai), 8-I/B (Brasil), 8-I/B (Uruguai), 8-I/C , 8-I/ D, 8I/E e 8-I/F; e, ainda, o Marco Monumental Rio Branco e o Marco Principal 8-P, estes já no Cerro de Acegua.

XIII. A partir do Marco Principal 8-P, prossegue a linha divisória, por uma linha reta de aproximadamente $37,2 \mathrm{~km}$, até a confluência do arroio São Luiz com o rio Negro. Neste trecho são encontrados 16 marcos, além dos extremos (8-P e 10-P), a saber:

XIV. Os marcos intermédios 9-I, 9-I/A, 10-I, 10-I/A, 11-I até 16-I, 16I/A, 17-I até 19-I;

XV. O Marco Principal 9-P (Passo da Carpintaria) e o marco intermédio 20-I, na margem esquerda do rio Negro. No mesmo alinhamento, já na margem do arroio São Luiz, em território uruguaio, está o Marco Principal (de referência) 10-P. 
XVI. Segue agora a linha divisória cerca de $25,5 \mathrm{~km}$ pelo álveo do arroio São Luiz até o marco intermédio $20-\mathrm{I} / \mathrm{C}$, local onde o arroio se descaracteriza, tornando-se um banhado ("Banhado dos Três Marcos"). Neste trecho são encontrados, além de seus extremos (10-P e 20-I/C), outros quatro marcos intermédios (de referência): 20-I/A (Brasil) e 20-I/A (Uruguai), na região do Passo do Lajeado e 20-I/B (Brasil), 20-I/B (Uruguai), na região do Passo Real do arroio São Luiz.

XVII. Na altura do Marco 20-I/C a linha divisória abandona em ângulo reto o leito do arroio e segue pelo "Banhado dos Três Marcos", por $1,3 \mathrm{~km}$, em linha reta materializada pelos marcos intermédios 20-I/C, 20-I/D e 20-I/E. A partir deste, a linha divisória percorre uma pequena sanga e retorna ao leito do arroio São Luiz, seguindo pelo álveo do mesmo, numa distância aproximada de $4,5 \mathrm{~km}$, até a confluência dos galhos Norte e Sul do arroio, junto ao marco intermédio (de referência) 20-I/G (na margem uruguaia). Neste trecho são encontrados os marcos (de referência) 20-I/F (Brasil) e 20-I/F (Uruguai), localizados em uma e outra margem do arroio, cerca de 300 metros antes da confluência acima citada.

XVIII. A partir da confluência, a linha divisória segue pelo álveo do ramal Norte do arroio, por mais uns 160 metros, até o par de marcos 21-I (Brasil e Uruguai); Daí tem início novo banhado (conhecido na Comissão Mista por "Banhado dos Cinco Marcos"). Neste pequeno trecho são encontrados os seguintes pares de marcos, todos de referência: 20-I/H (Brasil e Uruguai); 20-I/I (Brasil e Uruguai) e 21-I (Brasil e Uruguai). Na altura do par de marcos 21-I (Brasil e Uruguai), local onde tem inicio o "Banhado dos Cinco Marcos", a linha divisória abandona o arroio e segue uma linha reta de $1,2 \mathrm{Km}$, ligando o marco 21-I (Uruguai), que neste ponto passa a ser marco de limite aos marcos 21-I/A e 22-I (Uruguai). 
XIX. A partir deste ponto, volta a linha divisória ao ponto médio do galho norte do arroio, entre os marcos 22-I (Brasil) e 22-I (Uruguai), e segue cerca de $2,2 \mathrm{~km}$ pelo seu álveo (com o nome local de "Lagoa São Luiz") até a altura do marco intermédio (de referência) 22-I/D. Neste trecho são encontrados os seguintes pares de marcos, todos de referência: 22-I/A (Brasil e Uruguai); 22-I/B (Brasil e Uruguai) e 22-I/C (Brasil e Uruguai).

$\mathrm{XX}$. Na altura do marco de referência 22-I/D (situado em território brasileiro), a linha divisória abandona o galho norte do arroio; segue por uma linha reta de pouco mais de $8,0 \mathrm{~km}$ passando pelos marcos intermédios 23-I a 28-I e 28-I/A e finaliza no álveo do galho sul do mesmo arroio, no ponto médio entre o marco 28-I/A, anteriormente citado e o marco de referência 29-I, no mesmo alinhamento, mas já em território uruguaio.

XXI. Segue a linha divisória, agora cerca de $4,0 \mathrm{~km}$ pelo álveo do galho sul do arroio São Luiz, passando entre os pares de marcos de referência 30-I (Brasil e Uruguai), 31-I (Brasil e Uruguai) e 32-I (Brasil e Uruguai). Na altura do par de marcos 32-I (Brasil e Uruguai), a linha divisória deixa o galho sul do arroio e segue por três linhas retas sucessivas (cerca de $600 \mathrm{~m}$ ), passando pelos marcos 32-I/A, 32-I/B, atingindo finalmente o Marco Principal 11-P (Serrilhada), na Coxilha de Santana.

XXII. Do Marco Principal 11-P (Serrilhada), prossegue a linha divisória por uma linha quebrada, assinalada por Marcos Intercalados que acompanham o divisor de águas da Coxilha de Santana, até as proximidades das cidades de Santana do Livramento no Brasil e Rivera no Uruguai. Nesta extensão de $167,8 \mathrm{~km}$, existe uma estrada em solo natural, que acompanha a linha, ora entrando no Brasil ora entrando no Uruguai, conhecida como "Corredor Internacional". Nesse setor encontram-se os Marcos Intercalados, de 1 até 668, bem como Marcos Intermédios, de 33-I até 41-I e o Marco Principal 12-P. 
XXIII. Seguido ao Marco Intermédio 668, localizado no chamado "Cerro Caqueira", na entrada de Santana do Livramento (Brasil) e Rivera (Uruguai), a linha divisória segue por ruas e praças dessas cidades e corta longitudinalmente a "Praça Internacional". Ao longo deste trecho, de 6,7 km, além dos Marcos Intercalados (669 até 676), os marcos urbanos de deslinde, numerados de I até XXV, e novamente os marcos intercalados 677, 678 e 679, na parte noroeste das cidades, na parte central, o Marco Intermédio 42-I.

XXIV. Segue a linha divisória por mais $83,7 \mathrm{~km}$, ao longo de uma linha quebrada, assinalada por marcos intercalados que acompanham o divisor de águas da Coxilha de Haedo, até as nascentes do arroio Invernada. Continua neste trecho da fronteira o chamado "Corredor Internacional". Ao longo desse trecho, os Marcos Intercalados 680 a 1022, bem como os Marcos Intermédios 43-I a 49-I, este localizado na nascente do arroio Invernada, onde se encontram as vilas Albornoz (Brasil) e Massoller (Uruguai).

XXV. Segue a linha divisória cerca de $36,9 \mathrm{~km}$ pelo arroio Invernada até o ponto onde este encontra o arroio Espinilho, formando o rio Quarai. Não existe marco neste trecho da fronteira. Desce a linha divisória pelo rio Quarai até a sua foz no rio Uruguai, percorrendo cerca de 313,8 km e passando pelas cidades de Quaraí (brasileira) e Artigas (uruguaia), pelas de Barra do Quarai (brasileira) e Bella Union (uruguaia), bem próximas à Barra do rio Quarai no rio Uruguai. Também não existe marco neste trecho da fronteira.

XXVI. Na foz do Quarai, no rio Uruguai, encontra-se a "Ilha Brasileira", que, por disposição expressa do Tratado de 1851, foi adjudicada ao Brasil, razão pela qual, os demarcadores brasileiros construíram, em 1862, o Marco Principal 13-P, na sua extremidade sudoeste. Este trecho da fronteira tem a extensão de 4,0 km, e confronta-se no lado oeste da Ilha Brasileira, com o limite entre o Brasil e a Argentina. 
As fronteiras brasileiras, como visto, dividem também recursos naturais, especificamente recursos hídricos, dentre os quais destacamos: ao sul, o rio Jaguarão, Bacia da Lagoa Mirim e Lagoa dos Patos, rios Guarai, Uruguai na fronteira com o Uruguai.

A fronteira entre Argentina e Brasil fica estabelecida ao longo do curso do rio Peperi-Guaçu; a sudoeste, na Bacia do Prata, com Uruguai, Argentina, Paraguai e Bolivia, com especial referência aos rios Paraná e Iguaçu limites naturais com o Paraguai.

O município de Entre Rios do Oeste, situado no extremo oeste do Paraná defronta-se com a República do Paraguai através do lago de Itaipu; o rio Paraná banha parcialmente a região Sul e separa o Paraná do Mato Grosso do Sul e do Paraguai.

Ao norte e noroeste, o rio Amazonas e seus afluentes na fronteira com a Bolívia, Peru, Colômbia, Venezuela, Guiana e Suriname.

A linha de limites entre o Brasil e o Suriname, inicia-se no ponto de trijunção das fronteiras Brasil-Suriname-Guiana (na Serra de Tumucumaque), situado entre as cabeceiras dos rios Uanamú (no Brasil) e Kutarí (fronteira entre o Suriname e a Guiana). Segue pelo mais alto do terreno (divisão das águas) que separam a bacia do Amazônas, ao sul das bacias dos cursos de água que fluem para o norte, até o ponto tríplice Brasil-Suriname-Guiana Francesa (ainda na Serra de Tumucumaque), situado este, entre as cabeceiras dos rios Mapaoni (no Brasil) e Litana (afluente do Mapaoni, fronteira entre o Suriname e a Guiana Francesa). 


\subsection{Bacias hidrográficas e os rios brasileiros}

\subsubsection{Principais características dos rios brasileiros}

O Brasil possui um grande número de rios, os quais formam, em seu conjunto, a mais densa rede hidrográfica do Planeta, em função da extensão de seu território, da uniformidade das formas dominantes de seu relevo e dos climas com elevada pluviosidade, com exceção de alguns pontos da região nordestina.

A alimentação dos rios brasileiros é praticamente de exclusiva dependência das chuvas, não há ocorrência de regimes provenientes de neve ou de geleiras, somente o rio Amazonas registra em parte águas provenientes do derretimento da neve existente na cordilheira dos Andes, onde nasce, mas sua maior alimentação é pluvial.

A grande maioria dos rios brasileiros é perene, com padrão de drenagem exorréico, correndo todos para o oceano Atlântico, uma vez que a barreira representada pela cordilheira dos Andes impede que qualquer rio brasileiro siga em direção ao oceano Pacífico.

Verifica-se, assim, que o Brasil, em decorrência de sua grande extensão territorial e da predominância de climas úmidos, tem uma extensa rede hidrográfica que, no geral, apresenta as seguintes características:

a) Só apresenta lagos de várzea e lagoas costeiras, formadas por restingas; não apresenta lagos tectônicos, uma vez que as depressões transformaram-se em bacias sedimentares. 
b) Predominam os rios de planalto em áreas de elevado índice pluviométrico, possibilitando a produção de hidreletricidade, em razão de muitos desníveis no terreno e o grande volume de água.

c) Somente o Sertão nordestino, onde predomina o clima semi-árido, apresenta rios temporários. Nas demais regiões do Brasil os rios são perenes.

d) Todos os rios brasileiros possuem regime pluvial, com exceção do rio Amazonas cujas águas provém também do derretimento de neve na cordilheira dos Andes, embora seja uma pequena quantidade de suas águas oriunda do regime nival e a maior parte delas fruto do regime pluvial, tem caracterizado o regime misto.

e) Todos os rios brasileiros são exorréicos, tendo como destino final o oceano.

f) Todos os rios brasileiros que deságuam livremente no oceano formam estuários, com exceção do rio Parnaíba, que possui foz em delta, e o rio Amazonas, que possui foz mista, em delta e estuário.

Tabela 2 - Navegação fluvial para transporte de $\operatorname{cargas}^{40}$ :

\begin{tabular}{|c|c|c|c|}
\hline \multicolumn{2}{|c|}{ DESLOCAMENTO DE CARGA SEGUNDO O TIPO DE TRANSPORTE } \\
\hline Paises & Rodovias & Ferrovias & Hidrovias \\
\hline Estados Unidos & $25 \%$ & $50 \%$ & $25 \%$ \\
Japão & $20 \%$ & $38 \%$ & $42 \%$ \\
Rússia & $5 \%$ & $82 \%$ & $13 \%$ \\
França & $28 \%$ & $55 \%$ & $17 \%$ \\
Brasil & $78 \%$ & $13 \%$ & $9 \%$ \\
\hline
\end{tabular}

${ }^{40}$ VESENTINI, 1999, p. 110. 
O custo do transporte de carga rodoviário é pouco mais de quatro vezes menos econômico que o ferroviário em quase vinte vezes menos econômico que o hidroviário. No entanto, como se verifica na Tabela 2 , em comparação a outros meios de transporte de cargas, a utilização dos rios brasileiros para transporte é mínima, uma incongruência, considerando a qunatidade de rios navegáveis que cortam toda a extensão territorial do Brasil, em muitos casos, transpondo suas fronteiras.

Tabela 3 - Potencial hidrelétrico ${ }^{41}$ :

\begin{tabular}{|lr|}
\hline \multicolumn{2}{|c|}{ POTENCIAL HIDRELÉTRICO SEGUNDO AS BACIAS FLUVIAIS } \\
\hline Bacia Amazônica & $105.550 \mathrm{MW}$ \\
Bacia do Tocantins & $27.821 \mathrm{MW}$ \\
Bacia do Paraná & $27.358 \mathrm{MW}$ \\
Bacia do São Francisco & $26.354 \mathrm{MW}$ \\
Bacia do Uruguai & $13.902 \mathrm{MW}$ \\
Bacia do Leste & $14.469 \mathrm{MW}$ \\
Bacias do Sul e Sudeste & $9.622 \mathrm{MW}$ \\
Outras & $3.979 \mathrm{MW}$ \\
Total do Brasil & $259.055 \mathrm{MW}$ \\
Total aproveitado (até 1995) & $58.300 \mathrm{MW}$ \\
\hline
\end{tabular}

O maior aproveitamento dos rios brasileiros se dá como fonte de energia. Cerca de $90 \%$ da eletricidade no Brasil provém de fontes hidráulicas, porém, como se verifica na Tabela 3, do potencial existente, menos de $30 \%$ é utilizado.

\footnotetext{
${ }^{41}$ VESENTINI, 1999, p. 95.
} 


\subsubsection{Bacias hidrográficas do Brasil}

Denomina-se bacia hidrográfica a área abrangida por um rio principal e sua rede de afluentes e subafluentes.

O Brasil possui cinco bacias hidrográficas principais e três bacias secundárias. São elas:

1. Bacias hidrográficas principais:

a) Bacia Amazônica: abrange seis milhões de quilômetros quadrados na América do Sul, dos quais quatro milhões estão localizados no Brasil. É considerada a maior bacia hidrográfica do globo terrestre. É formada pelo rio Amazonas, mais importante do globo em volume de água (o rio Amazonas, por sua vez, é formado pela união das águas dos rios Solimões e Negro), e seus inúmeros afluentes, os quais provèm tanto do hemisfério norte, oriundos do planalto das Guianas e que deságuam na sua margem esquerda, quanto do hemisfério sul, procedentes do planalto brasileiro e que deságuam na sua margem direita. Seus principais afluentes são: os rio Javari, Juruá, Purus, Madeira, Tapajós e Xingu, na margem direita; e Içá, Japurá, Jamundá, Trombetas, Maicuru, Paru e Jarí, na margem esquerda.

b) Bacia do Tocantins: ocupa 9,5\% do território nacional, sendo a maior bacia localizada totalmente no território brasileiro. É formada pelo rio Tocantins e seus afluentes, dos quais o principal é o rio Araguaia, tão importante em seu volume de água e extensão que também recebe o nome de bacia de Tocantins-Araguaia, tendo dado origem entre outras, a usina hidrelétrica de Tucuruí, a maior da região amazônica e segunda maior do país. 
c) Bacia do Paraná: formada pelo rio Paraná e seus afluentes, dos quais destacam-se o Tietê, Paranapanema, Peixe, Iguaçu, Ivai, Corrente, Verde, Pardo e Amambaí, entre outros, além dos dois rios que o formam ao se juntarem: o Paraíba e o Grande. Possui elevado potencial hidrelétrico, sendo o mais aproveitado no Brasil, abrigando a maior hidrelétrica do mundo, a usina binacional de Itaipu, entre o Brasil e o Paraguai. O rio Paraguai é considerado, no Brasil, como parte da bacia do Paraná, é um típico rio de planície utilizado internacionalmente como hidrovia, seu maior porto pluvial é o de Corumbá no Mato Grosso do Sul, Brasil.

d) Bacia do Uruguai: formada pelo rio Uruguai, o qual nasce da junção dos rios Canoas e Pelotas, e seus afluentes. Possui trechos de planalto e planície, sendo utilizado para navegação e geração de energia elétrica, sendo que esta utilização está muito aquém de seu potencial.

e) Bacia do São Francisco: ocupa aproximadamente 7,5\% do território nacional. Formada pelo rio São Francisco, já foi conhecido como "rio da unidade nacional" por possibilitar as comunicações entre o sul e o nordeste e, também, por ser o maior rio exclusivamente brasileiro. A usina hidrelétrica de Paulo Afonso nela instalada é a principal responsável pelo abastecimento de energia da região nordeste. Seus principais afluentes são os rios Pará, Paraopeba, das Velhas, das Rãs e Salitre, pela margem direita; e Abaeté, Paracatu, Carinhanha, Corrente, Grande e Ipanema, pela margem esquerda.

2. Bacias hidrográficas secundárias:

a) Bacia do Norte-Nordeste: formada pelos rios do meio-norte do país, tais como o Parnaiba, Gurupi, Pindaré, Mearim e Itapicuru, além dos rios temporários do sertão nordestino, como os rios Jaguaribe, Aracau, Apodi, Piranhas, Capibaribe, entre outros. 
b) Bacia do Leste: é formada pelos rios Paraíba do Sul, Jequitinhonha, Doce, Itapicuru, Contas, Paraguaçu e Vaza-Barris, entre outros.

c) Bacia do Sudeste-Sul: entrecortada pelos rios Ribeira do Iguape, Itajaí, Tubarão, Camaquã e Jacuí, este último formador do Guaíba.

Figura 14 - Bacias hidrográficas ${ }^{42}$ :

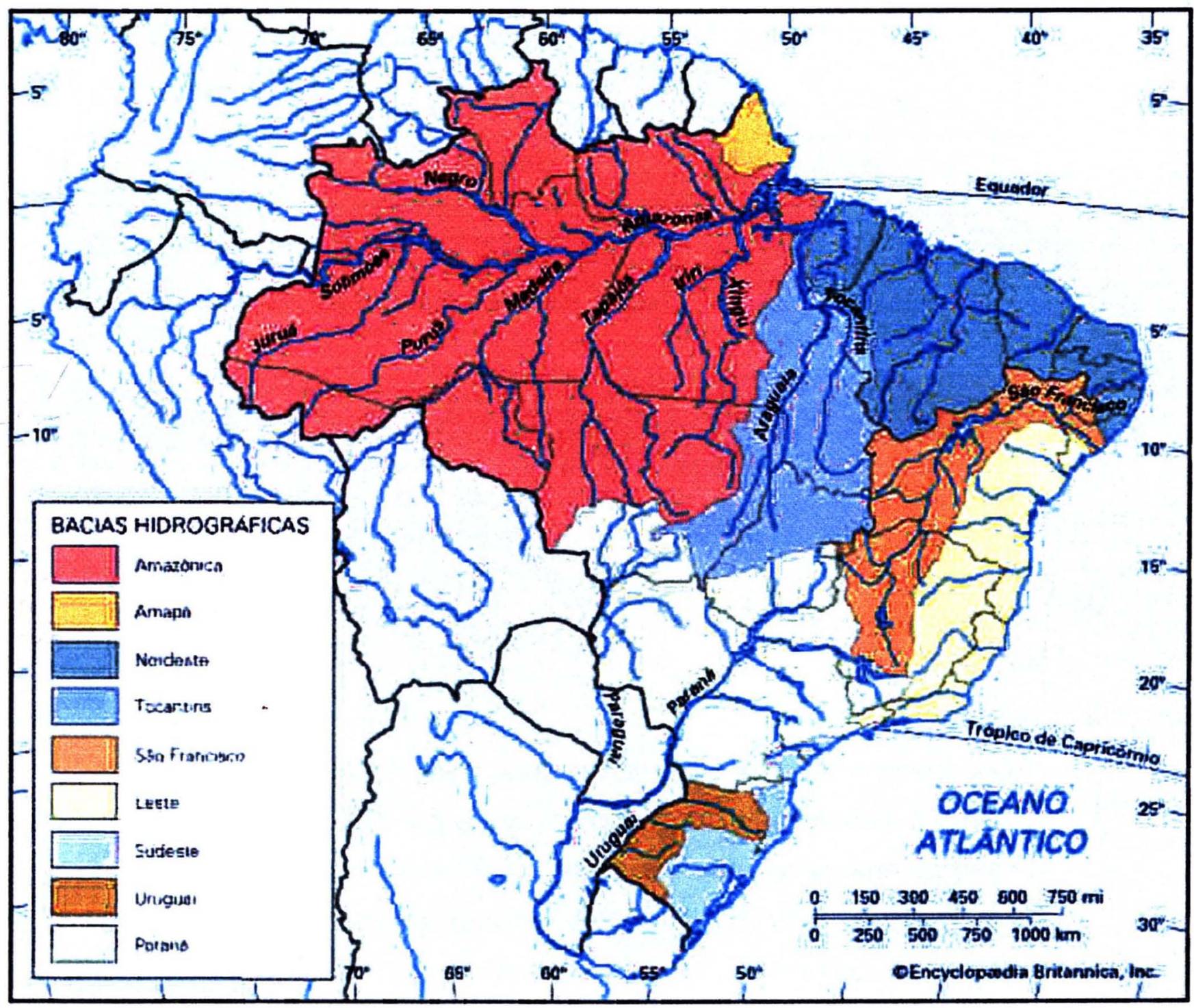

${ }^{42}$ O Departamento Nacional de Águas e Energia - DNAE, considera em sua classificação a Bacia Hidrográfica do Amapá, que inclui os rios do Atlântico Norte, rios da vertente atlântica do Estado do Amapá, como o Oiapoque, e mais as bacias independentes situadas no litoral oriental do Pará (Larousse Cultural, 1993). 
Tabela 4 - Bacias hidrográficas principais ${ }^{43}$ :

\begin{tabular}{|c|c|c|}
\hline $\begin{array}{c}\text { Bacias Hidrográficas } \\
\text { Principais }\end{array}$ & Superfície $\left(\mathrm{em} \mathrm{Km}^{2}\right)$ & Percentagem $^{44}$ \\
\hline Amazônica & 3.904 .393 & $45,89 \%$ \\
\hline do Tocantins & 813.674 & $9,56 \%$ \\
\hline do Paraná & 1.220 .412 & $14,35 \%$ \\
\hline do Uruguai & 177.494 & $2,08 \%$ \\
\hline do São Francisco & 645.067 & $7,58 \%$ \\
\hline
\end{tabular}

Tabela 5 - Bacias hidrográficas secundárias ${ }^{45}$ :

\begin{tabular}{|c|c|c|}
\hline $\begin{array}{c}\text { Bacias Hidrográficas } \\
\text { Secundárias }\end{array}$ & Superficie $\left(\mathrm{em} \mathrm{Km}^{2}\right)$ & Percentagem $^{46}$ \\
\hline do Norte-Nordeste & 990.229 & $11,6 \%$ \\
\hline Do Leste & 572.295 & $6,70 \%$ \\
\hline do Sudeste-Sul & 223.810 & $2,62 \%$ \\
\hline
\end{tabular}

Como se verifica da Tabela 4, a Bacia Amazônica constitui a maior bacia hidrográfica, correspondendo a, praticamente, metade da totalidade da área do Brasil e encontra-se em sua região menos habitada. Pela Figura 14, pode-se verificar que a Bacia Amazônica ocopa a a maior extensão de fronteira do país. A abundância hídrica da Região Norte é, ainda, confirmada na Tabela 5, comparativamente às demais bacias secundárias.

\footnotetext{
${ }^{43}$ VESENTINI, 1999, p. 265.

${ }^{44}$ Em relação à área total do país.

${ }^{45}$ VESENTINI, 1999, p. 265.

${ }^{46} \mathrm{Em}$ relação à área total do país.
} 


\subsubsection{Nova classificação das bacias hidrográficas conforme legislação ambiental}

O Conselho Nacional de Recursos Hídricos - CNRH, no uso das competências, conferidas pela Lei $\mathrm{n}^{\circ}$ 9.433, de 8 de janeiro de 1997, regulamentada pelo Decreto ${ }^{\circ} 2.612$, de 3 de junho de 1998 , e tendo em vista o disposto em seu Regimento Interno aprovado pela Portaria $\mathrm{n}^{\circ} 407$, de 23 de novembro de 1999, e considerando a importância da redefinição da sistemática para codificação de bacias hidrográficas para a Política Nacional de Recursos Hídricos, o Sistema Nacional de Gerenciamento de Recursos Hídricos e a gestão dos recursos hídricos no âmbito nacional, em particular para a elaboração do Plano Nacional de Recursos Hídricos; visando a necessidade de se adotar metodologia de referência que permita procedimentos padronizados de subdivisões e agrupamentos de bacias e regiões hidrográficas e em atendimento à necessidade de sistematização e compartilhamento de informações, preconizada na Lei $n^{\circ} 9.433$, de 8 de janeiro de 1997, que requer o referenciamento de bases de dados por bacias hidrográficas, unidade básica do gerenciamento de recursos hídricos; resolve codificar as bacias hidrográficas pela Resolução $n^{\circ}$ 30, de 11 de dezembro de 2002 e seus anexos.

$\mathrm{O}$ engenheiro brasileiro Otto Pfafstetter ${ }^{47}$, desenvolveu um método de subdivisão e codificação de bacias hidrográficas, utilizando dez algarismos, diretamente relacionado com a área de drenagem dos cursos d'água. Em 1998, a Secretaria de Recursos Hídricos do Ministério do Meio Ambiente coordenou um trabalho de classificação e codificação das bacias hidrográficas brasileiras segundo a referida metodologia, em nível de detalhe compatível com a escala da base utilizada, 1:1.000.000 $0^{48}$. Foi possível então caracterizar com maior consistência as bacias hidrográficas do continente sul-americano, e a metodologia foi aplicada da seguinte forma:

\footnotetext{
${ }^{47}$ Classificação de Bacias Hidrográficas - Metodologia de Codificação. Rio de Janeiro: DNOS, 1989.

${ }^{48}$ Texto explicativo contido no preâmbulo do anexo 1 da Resoluçăo no ${ }^{\circ} 30$, de 11/12/2002.
} 
- aplicação de código às quatro maiores bacias hidrográficas identificadas que drenam diretamente para o mar, sendo-lhes atribuidos os algarismos pares $2,4,6$ e 8 , seguindo o sentido horário em torno do continente;

- as demais áreas do continente foram agrupadas em regiões hidrográficas sendo-lhes atribuidos os algarismos ímpares 1, 3, 5, 7 e 9, de tal forma que a região hidrográfica 3 encontra-se entre as bacias 2 e 4, a região hidrográfica 5 encontra-se entre as bacias 4 e 6 , e assim sucessivamente;

- como forma de equacionar a aplicação de código na região hidrográfica que drena para o lago Titicaca, foi atribuído o algarismo zero para a mesma, determinando a subdivisão de nível 1 do continente.

Realizada a codificação continental, apresentando dez regiões hidrográficas, constituindo o nível 1, uma nova subdivisão foi feita a fim de obter-se o nivel 2 de bacias para o continente, da seguinte forma:

- considera-se como foz o ponto de descarga (exutório) da bacia a ser dividida; a análise é realizada sempre da foz para montante identificando todas as confluências e distinguindo o rio principal de seus tributários - o rio principal é aquele curso d'água que drena a maior área e os tributários, os demais que drenam áreas menores;

- faz-se a identificação dos quatro maiores tributários, de acordo com o critério da área drenada, classificados como bacias e que recebem, adicionalmente ao código aplicado no nivel 1, os algarismos pares 2,4 , 6 , e 8 , na ordem em que são encontradas de jusante para montante, ao longo do rio principal;

- em seguida, os demais tributários do rio principal são agrupados nas áreas restantes, classificados como regiões hidrográficas, que recebem, adicionalmente ao código aplicado no nivel 1 e na ordem em que são encontradas de jusante para montante ao longo do rio principal, os algarismos ímpares $1,3,5,7$ e 9 . 
Figura 15 - Representação das regiões hidrográficas:

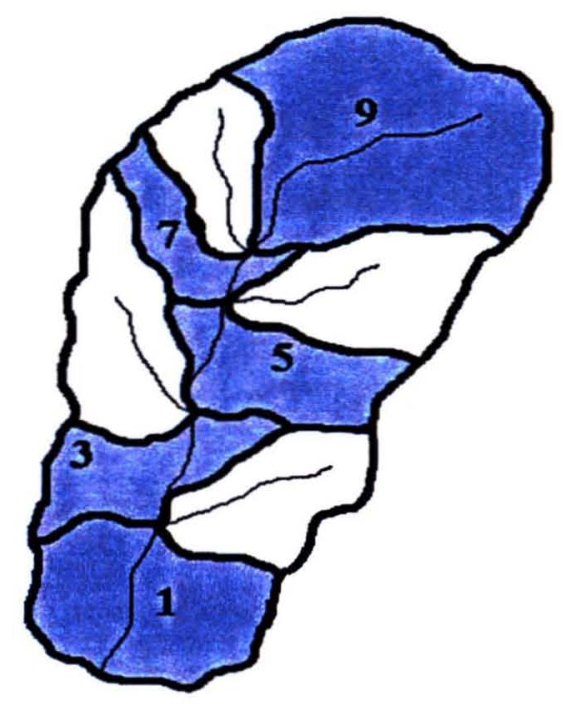

Figura 16 - Nível 2 de codificação das bacias e regiões hidrográficas:

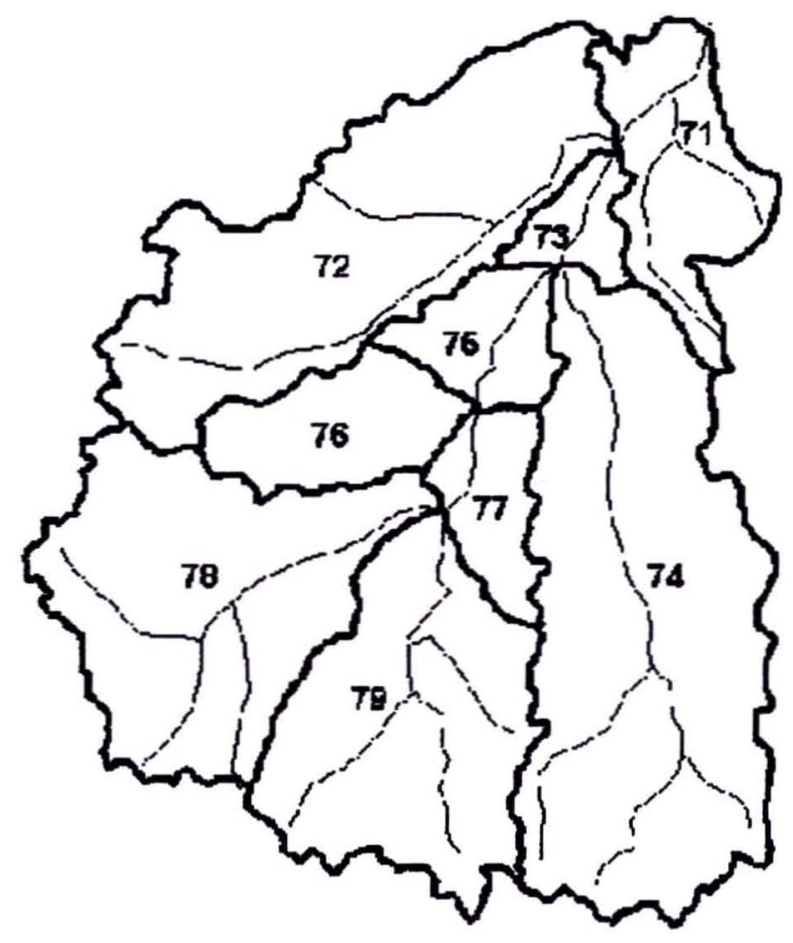


Observa-se, no exemplo representado na Figura 15, que uma bacia hidrográfica de nível 1 codificada com o algarismo 7 tem a seguinte subdivisão de nível 2 (Figura 16): a área 71 é a região hidrográfica compreendida entre a foz do rio principal e a confluência do rio da bacia 72; a área 73 é a região hidrográfica compreendida entre a confluência do rio da bacia 72 e a confluência do rio da bacia 74; a área 75 é a região hidrográfica compreendida entre a confluência do rio da bacia 74 e a confluência do rio da bacia 76; a área 77 é a região hidrográfica entre as bacias 76 e 78; a área 79 consiste sempre na área de cabeceira do rio principal a partir da bacia 78, e normalmente drena uma área maior do que a bacia 78 , pela definição.

Figura 17 - Codificação de Bacias Hidrográficas (Nível 1):

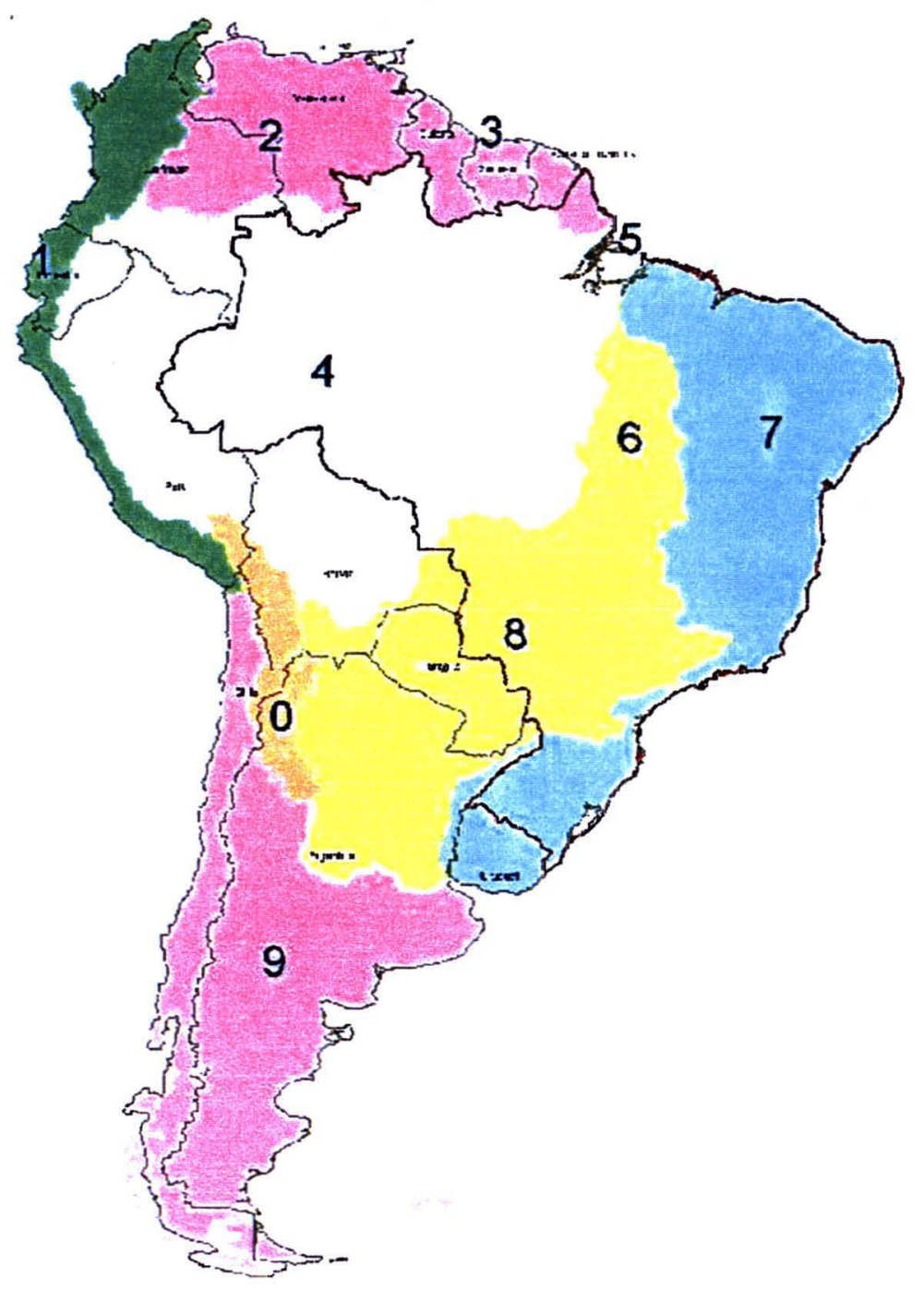


Verifica-se na Figura 17 as seguintes regiões hidrográficas:
a) Região número 0: Região Hidrográfica do Titicaca;
b) Região número 1: Região Hidrográfica Costeira do Pacífico;
c) Região número 2: Região Hidrográfica do Orinoco;
d) Região número 3: Região Hidrográfica Costeira do Atlântico Norte;
e) Região número 4: Região Hidrográfica do Amazonas;
f) Região número 5: Região Hidrográfica do Marajó;
g) Região número 6: Região Hidrográfica do Tocantins;
h) Região número 7: Região Hidrográfica Costeira do Atlântico Sul;
i) Região número 8: Região Hidrográfica do Paraná;
j) Região número 9: Região Hidrográfica dos Pampas.

A Resolução $n^{\circ} 32$, de 15 de outubro de 2003, do Conselho Nacional de Recursos Hídricos-CNRH, instituiu a Divisão Hidrográfica Nacional, em regiões hidrográficas, com a finalidade de orientar, fundamentar e implementar o plano nacional de recursos hídricos.

O parágrafo único do artigo $1^{\circ}$ da citada Resolução, considera como região hidrográfica o espaço territorial brasileiro compreendido por uma bacia, grupo de bacias ou sub-bacias hidrográficas contiguas com características naturais, sociais e econômicas homogêneas ou similares, com vistas a orientar o planejamento e gerenciamento dos recursos hídricos. 
Figura 18 - Divisão Hidrográfica Nacional ${ }^{49}$ :

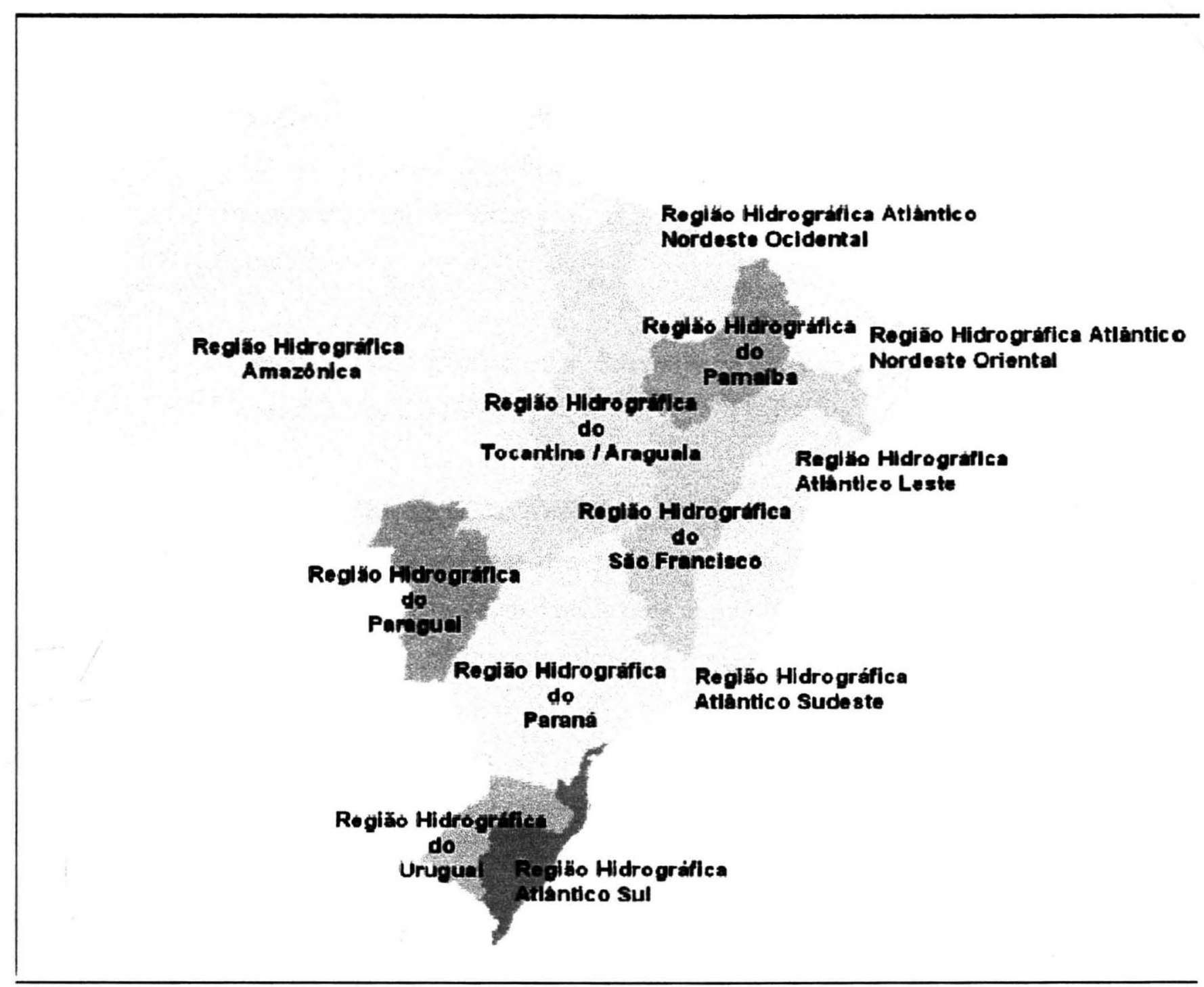

A atual Divisão Hidrográfica Nacional é feita na seguinte conformidade:

a) Região Hidrográfica Amazônica: É constituída pela bacia hidrográfica do rio Amazonas situada no território nacional e, também, pelas bacias hidrográficas dos rios existentes na Ilha de Marajó, além das bacias hidrográficas dos rios situados no Estado do Amapá que deságuam no Atlântico Norte.

\footnotetext{
${ }^{49}$ Instituída pela Resolução $\mathrm{n}^{\circ} 32$, de 15 de outubro de 2003, do Conselho Nacional de Recursos Hídricos.
} 
b) Região Hidrográfica do Tocantins/Araguaia: É constituida pela bacia hidrográfica do rio Tocantins até a sua foz no Oceano Atlântico.

c) Região Hidrográfica Atlântico Nordeste Ocidental: É constituída pelas bacias hidrográficas dos rios que deságuam no Atlântico - trecho Nordeste, estando limitada a oeste pela região hidrográfica do Tocantins/Araguaia, exclusive, e a leste pela região hidrográfica do Parnaíba.

d) Região Hidrográfica do Parnaíba: É constituída pela bacia hidrográfica do rio Parnaíba.

e) Região Hidrográfica Atlântico Nordeste Oriental: É constituída pelas bacias hidrográficas dos rios que deságuam no Atlântico trecho Nordeste, estando limitada a oeste pela região hidrográfica do Parnaíba e ao sul pela região hidrográfica do São Francisco.

f) Região Hidrográfica do São Francisco: $\dot{E}$ constituida pela bacia hidrográfica do rio São Francisco.

g) Região Hidrográfica Atlântico Leste: É constituída pelas bacias hidrográficas de rios que deságuam no Atlântico - trecho Leste, estando limitada ao norte e a oeste pela região hidrográfica do São Francisco e ao sul pelas bacias hidrográficas dos rios Jequitinhonha, Mucuri e São Mateus, inclusive.

h) Região Hidrográfica Atlântico Sudeste: É constituída pelas bacias hidrográficas de rios que deságuam no Atlântico - trecho Sudeste, estando limitada ao norte pela bacia hidrográfica do rio Doce, inclusive, a oeste pelas regiões hidrográficas do São Francisco e do Paraná e ao sul pela bacia hidrográfica do rio Ribeira, inclusive. 
i) Região Hidrográfica do Paraná: É constituída pela bacia hidrográfica do rio Paraná situada no território nacional.

j) Região Hidrográfica do Uruguai: É constituída pela bacia hidrográfica do rio Uruguai situada no território nacional, estando limitada ao norte pela região hidrográfica do Paraná, a oeste pela Argentina e ao sul pelo Uruguai.

k) Região Hidrográfica Atlântico Sul: É constituida pelas bacias hidrográficas dos rios que deságuam no Atlântico - trecho Sul, estando limitada ao norte pelas bacias hidrográficas dos rios Ipiranguinha, Iririaia-Mirim, Candapuí, Serra Negra, Tabagaça e Cachoeria, inclusive, a oeste pelas regiões hidrográficas do Paraná e do Uruguai e ao sul pelo Uruguai.

I) Região Hidrográfica do Paraguai: É constituida pela bacia hidrográfica do rio Paraguai situada no território nacional. 
“... Sofreis da pressa, e, a um tempo, da lembrança

Rios vosso pranto, que no mar se lança,

Rios tristes! agita-se a ansiedade

De todos os que vivem da esperança

De todos os que morrem de saudade...

Desejais regressar." 50

\section{3. ÁGUA E SAÚdE PÚBLICA}

\section{1. Água como fonte de vida}

\subsubsection{Generalidades}

Água s.f. (do latim aqua) 1. Substância liquida, em condições normais de pressão e temperatura, incolor, inodora, insípida, cujas moléculas são formadas por um átomo de oxigênio e dois átomos de hidrogênio $\left(\mathrm{H}_{2} \mathrm{O}\right)^{5 l}$

Água s.f. Liquido natural, incolor e inodoro, que se compõe de hidrogênio e oxigênio. ${ }^{52}$

Água s.f. substância liquida, transparente sem cheiro nem sabor, que refrange a luz e é suscetivel de dissolver muitos corpos e substâncias. ${ }^{53}$

\footnotetext{
${ }^{50}$ Trecho do poema "Os Rios", de Olavo Bilac, citado por Aristides Almeida Rocha em "Tietê, Rio Poético - uma coletânea", 1997, p.3.

${ }^{51}$ Enciclopédia Larousse Cultural, 1990, v. 1, p. 120.

52 Dicionário Moderno da Língua Portuguesa, 1986, p. 85.

${ }^{53}$ Dicionário Contemporâneo da Língua Portuguesa Caldas Aulete, 1990, p. 117.
} 
A água é a substância mais comum da Terra. Cobre mais de $70 \%$ da superficie terrestre. Forma os oceanos, rios e lagos, embebe o solo, e está no ar que respiramos. A água está em toda a parte.

$\mathrm{Na}$ antiga filosofia, a água era considerada como um dos quatro elementos que formavam o universo. Tales de Mileto, o primeiro filósofo de que se tem notícia, considerava a água a origem de todas as coisas. Não se sabe o que exatamente ele queria dizer com isto. Talvez ele quisesse dizer que toda forma de vida surge na água e a ela retorna quando se desfaz (GAARDER, 2000; e RUSSEL, 2001).

Ainda no campo da filosofia, Heráclito de Éfeso (540-480 a.C.) acreditava que a característica fundamental da natureza eram as constantes transformações: tudo flui, tudo está em movimento e nada dura para sempre. Para exemplificar suas idéias dizia que não podemos entrar duas vezes no mesmo rio, isto porque quando entramos pela segunda vez no rio, nem nós, nem o rio somos os mesmos.

Realmente a fluidez, a capacidade de modificação, de alteração, constitui a própria essência do elemento água.

Através da história, a água tem sido para o homem tanto escrava como senhora. Grandes civilizações nasceram e se desenvolveram ao longo de rios e decaíram quando as águas deixaram de ser abundantes. As chuvas eram representadas por deuses e assim adoradas em diversas religiões. $\mathrm{Na}$ mitologia encontram-se inúmeras narrativas da criação, em que Deus toma como primeira providência a de dar forma às águas e ao regime dos rios (ROCHA, 1997). 
Nos rituais, desde as épocas mais remotas até os dias atuais, a água está presente, como símbolo de purificação, com forças curativas e fecundantes. Entre os gregos e romanos, a purificação se dava com a "água lustral”, água em que se tinha apagado um tição aceso tirado do fogo de um sacrificio. Os religiosos orientais realizavam a purificação através da "ablução", cerimônia que consistia em lavar o corpo ou uma parte do corpo $^{54}$. No batismo cristão a água também está presente. Os hindus purificam-se com o banho nas águas do rio Ganges; e para os bambaras, o deus Faro é o senhor do verbo e das águas que, do sétimo céu, lança a chuva purificadora e fecundante (ROCHA, 1997).

Em toda a Escritura Sagrada, desde o Velho Testamento, encontramos a água com destacada importância, não só para a saúde, mas, principalmente para a própria vida, remontando à própria criação do homem e de todas as coisas. Para os sumérios, desde 5.000 a.C. o deus Eiki, Água Primordial, reinava sobre todos os demais deuses, evidenciando a importância da água em todas as suas formas.

A água acompanhou a evolução da humanidade e, se perdeu seu caráter folclórico, não perdeu sua importância para o homem, ao contrário, tem cada vez mais marcada sua imprescindibilidade para a sobrevivência das espécies e da própria vida na Terra. Nos tempos mais modernos, além do aspecto científico, passa a água a ser cantada em prosa e verso:

"Água que nasce na fonte serena do mundo e que abre um profundo grotão. Agua que faz inocente riacho e deságua na corrente do ribeirão... "55

\footnotetext{
${ }^{54}$ COULANGES, 1998.

${ }^{55}$ Trecho da música "Planeta Água", Guilherme Arantes, 1981.
} 
“(...) Rio, vidraça do céu.

Das nuvens e das estrelas.

Tira retrato da Lua.

Da Lua quarto-crescente

Que mora no morro.

Lua que veste a cidade de branco

E tece rendado de marafunda

Na sombra das cajazeiras.

Rio de águas velhas.

Roladas das enxurradas.

Crescidas das grandes chuvas.

Chovendo nas cabeceiras.

Rio do princípio do mundo.

Rio da contagem das eras.

Rio-mestre de quimica.

Na retorta das corredeiras,

corrige canos, esgotos, bueiros,

das casas, das ruas, dos becos

da minha terra.

Rio, santo milagroso.

Padroeiro que guarda e zela

a saúde da minha gente.

da minha antiga cidade largada.

Rio de lavadeiras lavando roupa.

De meninos lavando o corpo.

De potes se enchendo d'água.

E quem já ficou doente da água do rio?

Quem já teve ferida braba, febre malina,

pereba, sarna ou coceira?

Rio, meu pobre Jó...

Cumprindo sua dura sina.

Raspando sua lazeira

nos cacos dos seus monturos.

Rio, Jó que se alimpa,

pela graça de Deus, Virgem Santa Maria,

nas cheias de suas enchentes

que carregam seus monturos. (...)"s6

${ }^{56}$ Rio Vermelho. Cora Coralina. Poemas dos Becos de Goiás e Estórias Mais, 1991, p. 53. 
Ainda, no dizer de Remy de Gourmont:

"O rio é uma pessoa. Tem nome. Este nome é muito velho, porque o rio, ainda que sempre moço, é muito antigo. Existia antes dos homens e antes das aves. Desde que os homens nasceram, amaram os rios, e tão logo souberam falar lhe deram nomes". 57

\section{E Fernando Pessoa:}

"Ó mar salgado

quanto do teu sal são lágrimas de Portugal

Por te cruzarmos tantas mães choraram

tantos filhos em vão rezaram

tantas noivas ficaram por casar

para que fosses nosso ó mar

Evaleu a pena?

Tudo vale a pena, se a alma não é pequena.

Quem quer passar além do Bojador

deve passar além da dor.

Deus ao mar perigo e abismo deu

mas nele é que se espelhou o céu". ${ }^{88}$

\footnotetext{
${ }^{57}$ Citado por Aristides Almeida Rocha em Tietê, Rio Poético: uma coletânea. 1997, p.3.

58 “Mar português" (http://www.pessoafernando.hpg.ig.com.br).
} 


\subsubsection{Hidrologia}

O volume de água existente na Terra é calculado em 1.360 milhões de $\mathrm{km}^{3}$, dos quais $95,5 \%$ são águas salgadas, $2,2 \%$ estão imobilizados nas calotas polares e nas geleiras; apenas $2,3 \%$ correspondem à água doce utilizável, incluindose a dos lagos, cursos d'água, solo, subsolo e da atmosfera.

Figura 19 - Ciclo Hidrológico ${ }^{59}$ :

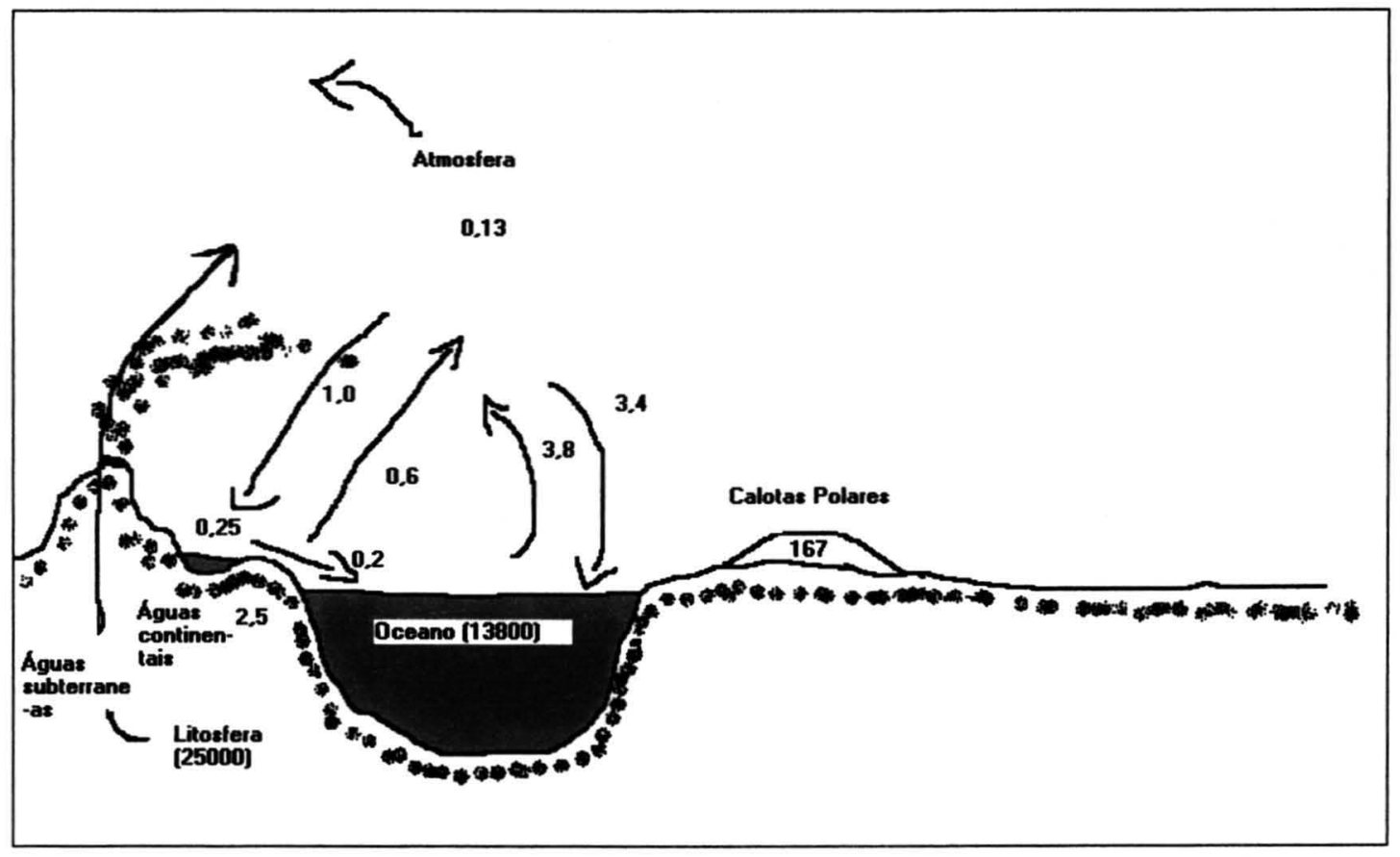

Os números da figura 19 representam geogramas $\left(10^{20}\right.$ gramas $)$ de $\mathrm{H}_{2} 0$ nos principais compartimentos (setas). Dados de Hutchinson, 1957. Na figura "B" está demonstrado o fluxo de energia no ciclo hidrológico, movido pela energia solar e que libera energia para os lagos, rios e pântanos e realiza o trabalho útil, de benefício direto para os seres humanos (e.g., a energia hidrelétrica). O escoamento de superfície recarrega e é recarregado pelos reservatórios de água subterrânea, embora o recarregamento de muitos destes reservatórios, em regiões secas, não esteja procedendo com a mesma velocidade com que estão sendo esvaziados para o uso humano. (ODUM, 1988).

${ }^{59}$ ODUM, 1988, p. 127. 
Figura 20 - Energia do ciclo hidrológico ${ }^{60}$ :

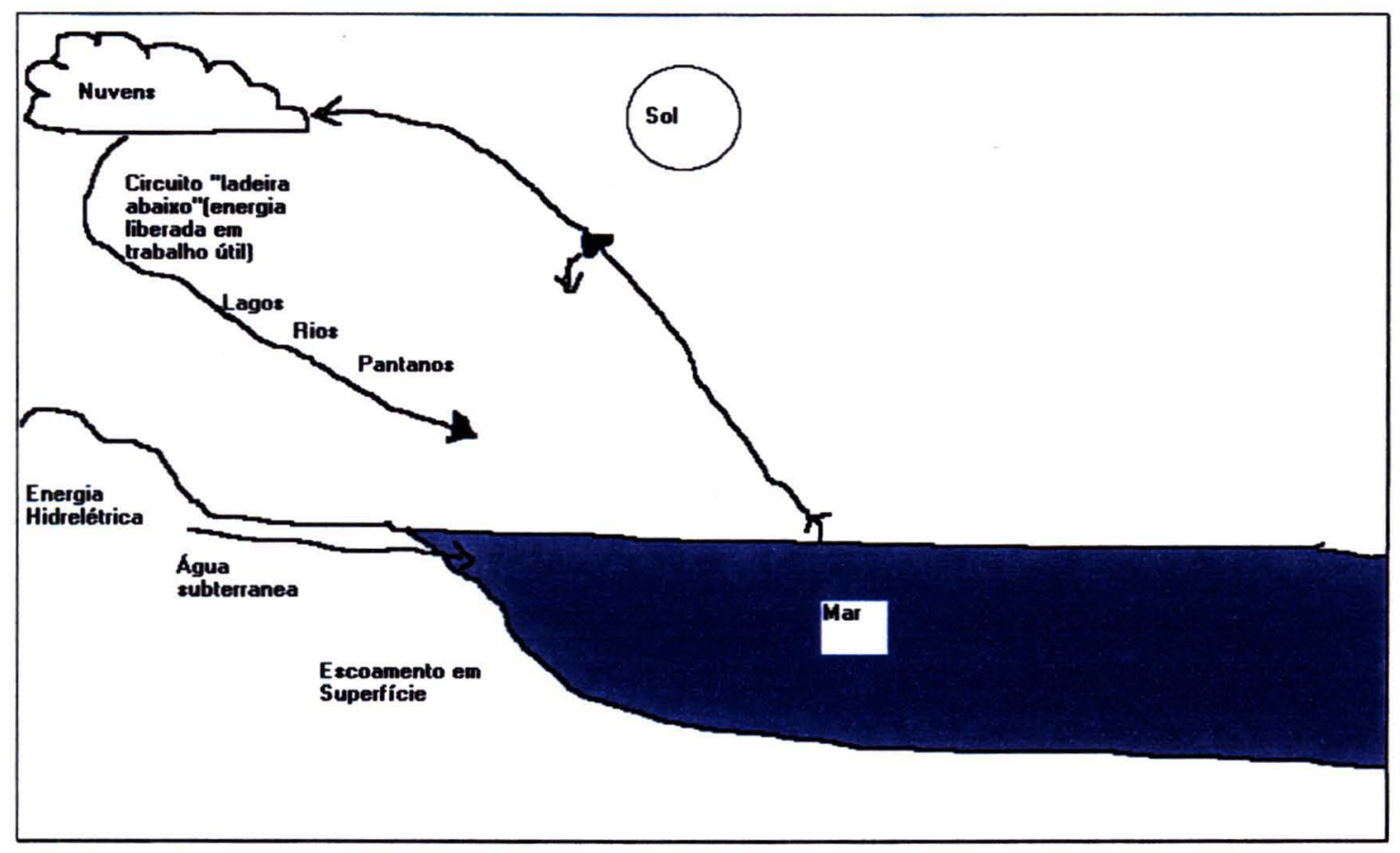

De acordo com ODUM (1988), dois aspectos do ciclo hidrológico merecem destaque:

1. Evapora do mar uma quantidade maior de água do que a que retorna por meio da precipitação, ocorrendo o inverso no continente. Assim, considerável parcela da precipitação que sustenta os ecossistemas terrestres, incluindo a maior parte da produção alimentar, provém da água evaporada sobre o mar.

2. Tendo em vista que uma quantidade estimada em 0,25 geograma ( 1 geograma $=10^{20}$ gramas ou $10^{14}$ toneladas) de água está em rios e lagos de água doce, e 0,2 geograma escoa todo o ano, o tempo de reposição é de cerca de um ano. A diferença entre a precipitação anual (1,0 geograma) e o escoamento (0,2 geograma), ou seja, 0,8 geograma, é uma estimativa da taxa anual de recarregamento das águas subterrâneas.

${ }^{60}$ ODUM, 1988, p. 129. 
Considerando que as atividades humanas tendem a aumentar a taxa do escoamento, com a realização de pavimentação da terra, retificação e canalização dos rios, compactação dos solos agrícolas, desmatamento e outras ações modificadoras do meio, há expressiva redução no recarregamento do muito importante compartimento de águas subterrâneas.

\subsection{Saúde e doença}

Todo ser vivo consiste principalmente de água e precisa dela para viver. O corpo humano contém cerca de $2 / 3$ de água, além disso, o consumo de água se dá não somente para o abastecimento, dessedentação e higiene, mas também para a agropecuária, indústria, geração de energia, transporte e recreação.

Assim, tem o homem a água como fonte maior de vida. Mas ao mesmo tempo pode ser o mais rápido e eficaz meio transmissor de doenças, uma vez que é sabido que muitos agravos à saúde têm origem nas condições ambientais inadequadas, oriundas da poluição do meio, em especial da água.

Dessa forma, os efeitos do desequilibrio ecológico ou poluição ambiental, especialmente no que respeita à água, afetam, direta ou indiretamente, a saúde pública.

Como citado anteriormente, saúde é um estado de completo bem estar físico, mental e social e não apenas a ausência de doença. E, do ponto de vista fisiológico: saúde é o estado de harmonia e equilibrio funcional, o também denominado silèncio orgânico. $\mathrm{Ou}$, ainda, a perfeita e contínua adaptação do organismo a seu ambiente (FORATTINI, 1996). 
A conceituação de doença, por sua vez, não simplesmente é o estado oposto ao de saúde, mas o conjunto de fenòmenos desenvolvidos em organismos, associados a uma característica, ou série de características comuns, que diferenciam esses organismos dos normais da mesma espécie, de modo a situá-los em posição biologicamente desvantajosa em relação àqueles (FORATTINI, 1996).

O processo saúde-doença está intimamente ligado às questões ambientais, uma vez que as condições ambientais, entre outros fatores, interferem diretamente no individuo como fator predisponente e mantenedor da doença. Assim, a poluição ambiental ou o desequilíbrio ecológico podem ser inseridos entre os problemas de saúde pública no Brasil, no qual a saúde ambiental é o objetivo especifico que interessa ao presente estudo.

Por sua vez, saúde pública é a atividade social que tem por objetivo a promoção e preservação da saúde da população (FORATTINI 1996). Como já foi mencionado, saúde pública é a ciência, é a arte de prevenir as doenças, de prolongar a vida e de promover a saúde e a eficiência física e mental, o que se dá pelos esforços organizados da comunidade, objetivando o saneamento básico, o controle das infecções, a educação sanitária, os serviços médicos e a prevenção das doenças, além do desenvolvimento social para a garantia de um padrão de vida adequado à manutenção da saúde para cada individuo da comunidade (Winslow, 1980, appud MOREIRA, 1992, p. 183).

Ainda, de acordo com FORATTINI (1996), o agravo à saúde caracterizase como problema de saúde pública quando puder ser incluído em uma ou mais das seguintes situações:

a) representar causa freqüente de morbidade e mortalidade.

b) existirem métodos eficientes para sua prevenção e controle, e que, portanto, devam ser aplicados. 
c) não estiverem sendo adequadamente empregados pela sociedade, os métodos existentes para solucionar o problema.

d) ao ser objeto de campanha destinada à sua erradicação, ocorrer persistência além do esperado.

A história natural da doença pressupõe o encadeamento de três fatores fundamentais: o agente, o suscetível e o meio ambiente (LEAVELL e CLARK, 1976). Com a evolução dos conhecimentos ecológicos, os fatores determinantes são cada vez mais considerados na gènese da doença. Passa-se, então, a empregar a ecologia da doença, considerando o encadeamento dos fatores determinantes de natureza física, biológica e social, incluindo-se a exposição, a suscetibilidade e as características do meio como propiciatório das condições necessárias para a ocorrència da doença e do nível da qualidade de vida (FORATTINI, 1996). Os fatores determinantes são endógenos, ou seja, referentes ao organismo, e exógenos, ou seja, concernentes ao ambiente, no qual se incluem os aspectos físicos, populacionais, comunitários e sociais.

Ainda comenta Forattini (1996) que o organismo (representado pelo genótipo), passa a se relacionar com o meio em que vive, a partir de sua etapa como gameta (resultante da fertilização do óvulo pelo espermatozóide). Desde esse momento, o desenvolver do fenótipo não dependerá apenas do genótipo, mas também do relacionamento que mantiver com o ambiente (no caso, o ser materno). E, mesmo nessa fase de vida intra-uterina, pode ocorrer a atuação de fatores ambientais. Após o nascimento, essa interação, longe de sofrer solução de continuidade, passa a se tornar mais diversificada, uma vez que o indivíduo torna-se, então, parte do meio onde passará todo o resto de sua vida. Dessa forma, sua saúde e probabilidade de sobrevivência dependerão da capacidade que vier a demonstrar de reagir favoravelmente aos estímulos dos múltiplos fatores ambientais, uma vez que os componentes físicos e biológicos do ambiente onde vive o homem somam-se aos da sociedade que este estabelece, tanto na determinação do seu estado de saúde, como na sua qualidade de vida (FORATTINI, 1992). 
E, se o campo de estudo para a compreensão do processo saúde-doença é o da interação dos humanos com as demais espécies e os ambientes físicos, cada vez mais será importante compreender o ambiente transformado pela ação da sociedade (CUNHA, 1996).

É preciso ressaltar, ainda, que a proteção da saúde depende, em muito, das decisões políticas, pois é a participação da sociedade o elemento mais importante para garantir a melhoria da saúde no pais, através da concretização das intenções que se apresentam, inicialmente, apenas como propostas (BERTOLLI FILHO, 1999).

Em países "em desenvolvimento" (e tanto mais nos paises subdesenvolvidos), a baixa, ou nenhuma, atenção disponibilizada às ações de saneamento básico e de saúde pública facilita o caminho para as epidemias. Paralelamente, a crescente pressão migratória de pessoas e o acelerado adensamento urbano contribuem para o aumento do contágio de doenças epidêmicas (PENNA, 1999).

O impacto dos investimentos em saneamento básico na saúde da população está ligado a uma série de fatores e, dentre eles, destacam-se:

- nivel de escolaridade e poder aquisitivo;

- qualidade das moradias;

- estado nutricional e hábitos alimentares;

- práticas de aleitamento materno e hidratação;

- disponibilidade de serviços de saúde, sistemas de abastecimento e tratamento da água.

Pesquisas indicam que a mudança no comportamento das pessoas em virtude da implantação dos serviços de saúde é mais acentuada quando são implantados, em conjunto, programas de educação sanitária. A alfabetização, por exemplo, principalmente das mães, é um dos fatores mais importantes para o aproveitamento dos benefícios do saneamento básico, que aumenta na mesma proporção que se intensificam as práticas higiênicas (MARTINS, 2001). 


\subsection{A qualidade da água}

Para assegurar um determinado uso, ou um conjunto de usos, é necessário que as águas possuam certas características mensuráveis, de natureza física, química e biológica, em intervalos de variação permissíveis.

Essas características constituem uma nova dimensão da água, denominada qualidade (SILVA, 1998).

A terminologia qualidade, quando relativo à água, é utilizado tanto para definir uma característica ou propriedade, como para designar um grau, valor ou mérito; podendo designar uma propriedade, ao descrevê-la, ou conferir-lhe determinado valor, ao avaliá-la. Em relação à água, as qualidades descritivas, também chamadas de qualidades naturais, podem ser objetos de padronização.

A água não tem cor, nem odor, assim, tais fatores, se ocorrentes, certamente serão originários da interferência de outras substâncias, motivo pelo qual essas qualidades passam a ser avaliativas e controláveis, pois em um corpo d'água será avaliada e padronizada, não a água propriamente dita, mas sim as substâncias estranhas à sua natureza, objeto de lançamento naquele sistema aquático, considerando os padrões estabelecidos para o uso a que ele se destina.

Dessa forma, para possibilitar seu efetivo controle, a qualidade da água deverá ser descrita sempre em termos quantitativos, sendo que o controle da qualidade dos corpos d'água envolverá o controle da poluição. Verifica-se, assim, que, os indicadores de poluição da água são os mesmos parâmetros físico-quimicos e biológicos que indicam a sua qualidade, ou seja, a qualidade é definida pela presença ou não de agentes poluentes em quantidades maiores que o padrão legal. 
A qualidade das águas está diretamente associada às suas características físicas e químicas e na distribuição de seres aquáticos, conforme suas necessidades de oxigênio e nutrientes. Indispensável é o conhecimento das características e os efeitos das substâncias nela dissolvidas por dois principais motivos:

- avaliação da possibilidade de sobrevivência das várias espécies nas diferentes regiões de um corpo d'água;

- conhecimento, ainda que em parte, do equilíbrio entre os elementos que interferem na sua composição e os organismos vivos que fazem parte da população aquática (ROCHA, 1995).

No Brasil, o Conselho Nacional do Meio Ambiente, através da Resolução CONAMA n ${ }^{\circ} 20$, de 18 de junho de 1986, classificou as águas para os diversos usos, estabelecendo padrões e critérios para enquadramento e controle dos níveis de qualidade a serem alcançados e/ou mantidos em cada segmento de corpo d'água ao longo do tempo, por categoria, de acordo com os usos a que se destinam. Nesta Resolução estão definidos os padrões de qualidade de cada uma das classes das águas, estabelecendo limites e condições às substâncias potencialmente prejudiciais que relaciona.

\subsection{A poluição da água e seus indicadores}

O outro lado a ser considerado na qualidade da água é o referente a sua poluição.

A poluição ambiental é um problema de saúde pública e, o saneamento do meio, um dos objetivos desta, na qual destacamos o problema da poluição das águas e, respectivamente, seu efetivo controle. 
Nesse sentido, importante se faz uma análise mais detalhada da poluição das águas, enquanto problemas emergenciais de saúde pública, uma vez que a contaminação da água é fonte de agravos maiores que colocam em risco não somente a qualidade de vida da população, mas a própria sobrevivência desta.

Denomina-se poluição, a interferência no meio ambiente, perturbando seu equilíbrio natural, o que pode ocorrer das mais variadas formas. Poluição ambiental pode ser definida como a adição ou o lançamento de qualquer substância ou forma de energia (luz, calor, som) ao meio ambiente em quantidades que resultem em concentrações maiores daquelas naturalmente encontradas (MOREIRA, 1992).

Poluição é também definida como qualquer alteração da composição e das características do meio que cause perturbações nos ecossistemas. Mas, essa conceituação não é pacificamente aceita, pois, além de prejudicar o significado etimológico da palavra poluir (que vem do latim poluere, que quer dizer sujar), não atende, também, aos objetivos práticos ligados ao controle da qualidade do meio ambiente (BRANCO e ROCHA, 1980).

No Brasil, a Lei Federal $n^{\circ} 6.938$, de 31 de agosto de 1981, em seu artigo $3^{\circ}$, inciso III, dá o conceito legal de poluição:

"poluição: a degradação da qualidade ambiental resultante de atividades que direta ou indiretamente:

a) prejudiquem a saúde, a segurança e o bem-estar da população;

b) criem condições adversas às atividades sociais e econômicas;

c) afetem desfavoravelmente a biota;

d) afetem as condições estéticas ou sanitárias do meio ambiente;

e) lancem matérias ou energia em desacordo com os padrões ambientais estabelecidos". 
Especificamente em relação à água, diversas são as fontes de poluição, classificadas de acordo com os tipos de poluentes que são fornecidos ao corpo d'água receptor:

a) degradáveis, que incluem os biodegradáveis, são aqueles poluentes que podem ser decompostos pelos processos naturais, a autodepuração, ou por técnicas de engenharia que procuram acelerar os processos naturais, como o esgoto doméstico e as cargas térmicas, conforme demonstrado na Figura 21.

Figura 21 - Fontes de poluição da água: fonte doméstica (esgoto) ${ }^{61}$ :

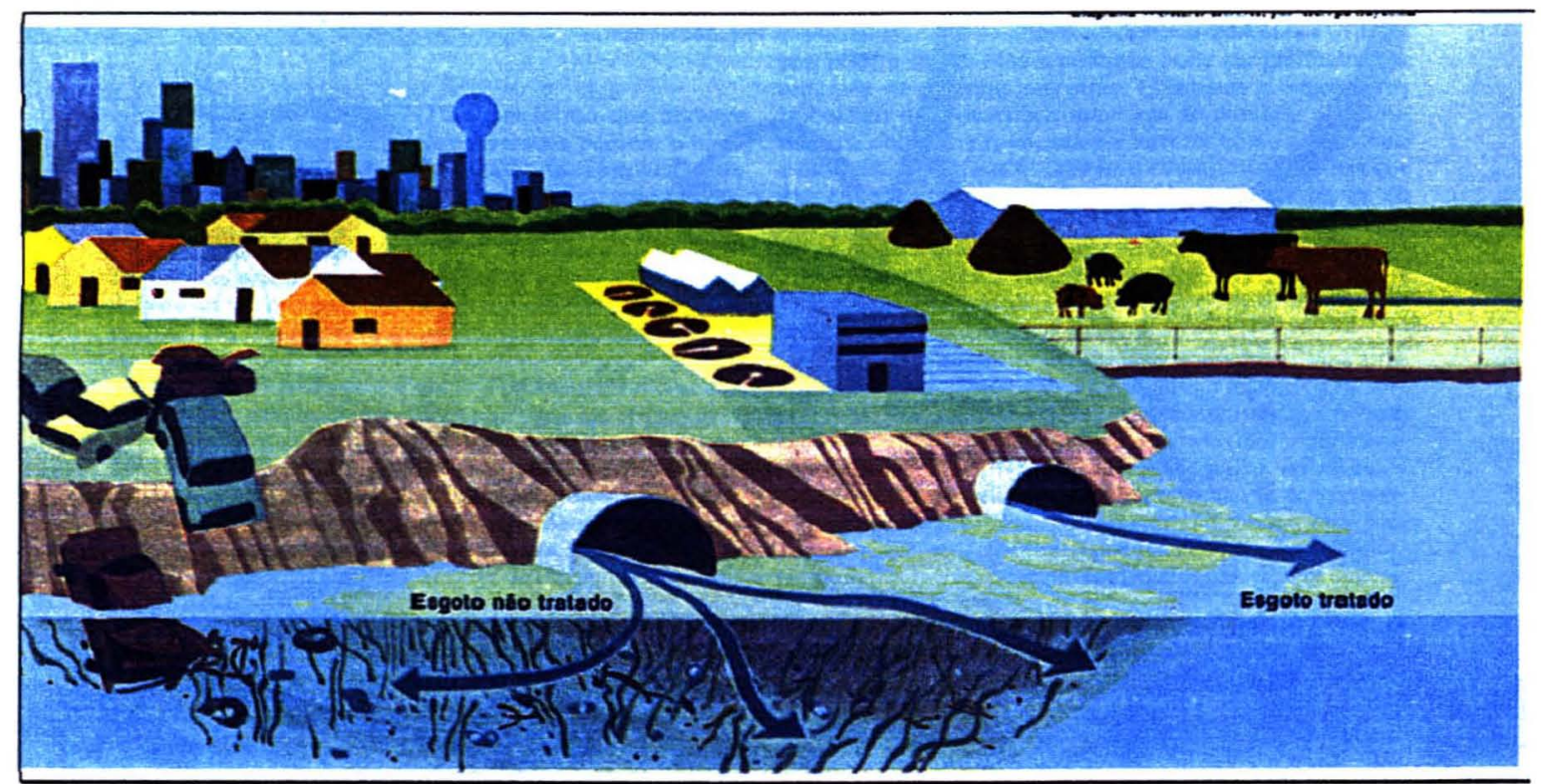

b) não-degradáveis, "biologicamente resistentes", "não biodegradáveis", "resistente a biodegradação" ou "recalcitrantes", são poluentes originados por compostos que podem ser diluídos ou mudar de forma no corpo d'água receptor, mas que não são reduzidos em sua massa, acumulando-se no meio aquático, podendo, não raras vezes, atingir elevados níveis de concentração, absolutamente prejudiciais à vida aquática, como os defensivos agrícolas, os detergentes, a celulose e os compostos de metais pesados, encontrados essencialmente na drenagem de minas e em muitos despejos industriais (BRANCO e ROCHA, 1980), conforme demonstrado na Figura 22.

\footnotetext{
${ }^{61}$ World Book (George Suyeoka), Enciclopédia Delta Universal, v. 12, 1982, p. 6532.
} 
Figura 22 - Fontes de poluição da água: fontes industriais e agrícolas ${ }^{62}$ :

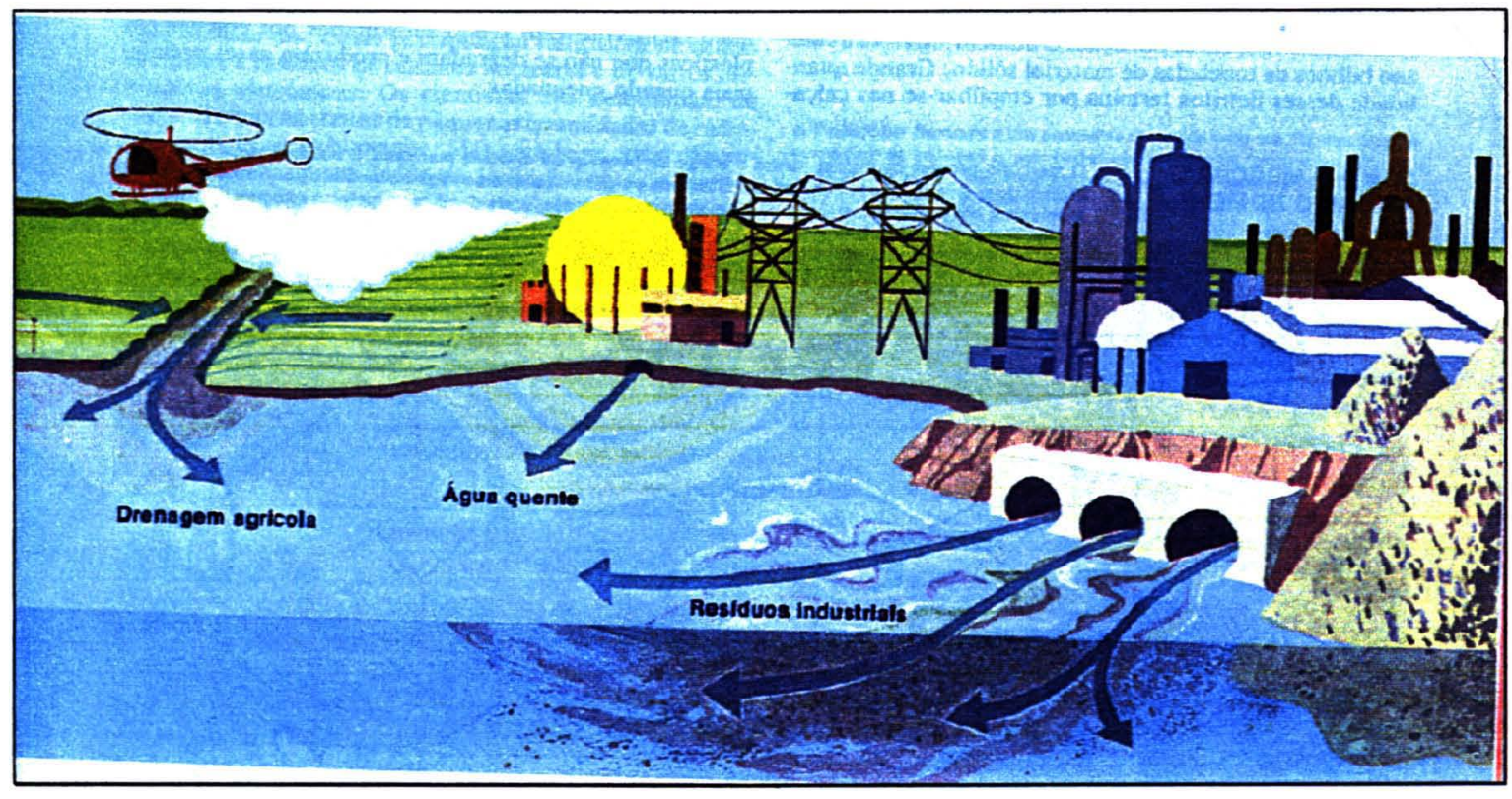

A contaminação da água é causada por inúmeros poluentes e é caracterizada por processos de transferência entre os compartimentos bióticos e abióticos do ecossistema aquático, pelos quais os poluentes se distribuem e interagem de acordo com suas características e com as condições do meio receptor (PASCHOAL, 1996).

Importante ressaltar que dentre esses vários poluentes, de origem industrial, doméstica ou agrícola, lançados no ar, no solo ou diretamente na água, as substâncias tóxicas ${ }^{63}$ são por demais preocupantes como ameaça maior à saúde pública, uma vez que estas se adsorvem no material particulado orgânico e são assimiladas pelos organismos detritívoros e/ou pelo fitoplâncton, chegando até os peixes e o homem em altas concentrações acumuladas ao longo da cadeia alimentar, conforme demonstra a Figura 23, apresentando efeito crônico sobre a saúde humana (PASCHOAL, 1996).

\footnotetext{
${ }^{62}$ World Book (George Suyeoka), Enciclopédia Delta Universal, v. 12, 1982, p. 6533.

${ }^{63}$ Metais pesados, compostos orgânicos sintéticos e radionuclídeos.
} 
Figura 23 - Transporte de poluentes tóxicos no ecossistema aquático ${ }^{64}$ :

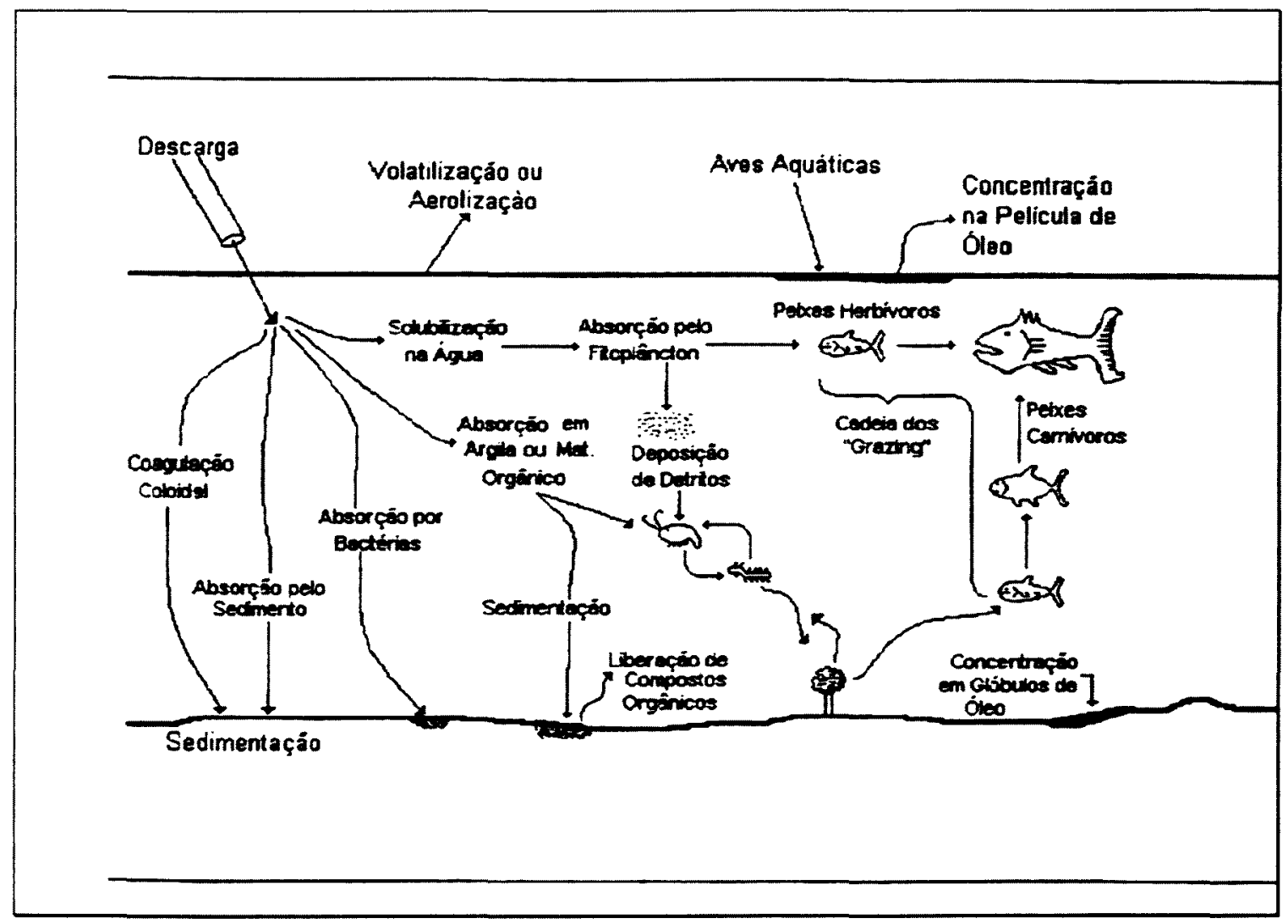

Um exemplo clássico esse tipo de ocorrência é o que se verifica em relação aos compostos de mercúrio ${ }^{65}$.

Embora, na maior parte das vezes, sejam lançados em forma inorgânica, os compostos de mercúrio sofrem ação de microrganismos da flora do lodo dos rios e oceanos (Figura 24), tornando-se, potencialmente, muito mais tóxicos e assimiláveis pela cadeia alimentar, elevando sua concentração nos peixes e outros animais marinhos, chegando até o homem (BRANCO e ROCHA, 1980).

\footnotetext{
${ }^{64}$ Westman, 1985, appud PASCHOAL, 1996.

${ }^{65} \mathrm{O}$ mercúrio provém de muitas fontes e atinge as pessoas de várias maneiras. É transportado diretamente pelo ar e pela água, se concentrando nos tecidos e órgãos vegetais e animais de que o homem se alimenta, é um poluente altamente perigoso, uma vez que em elevadas doses pode danificar o sistema nervoso humano (figura 24).
} 
Figura 24 - Contaminação por mercúrio ${ }^{66}$ :

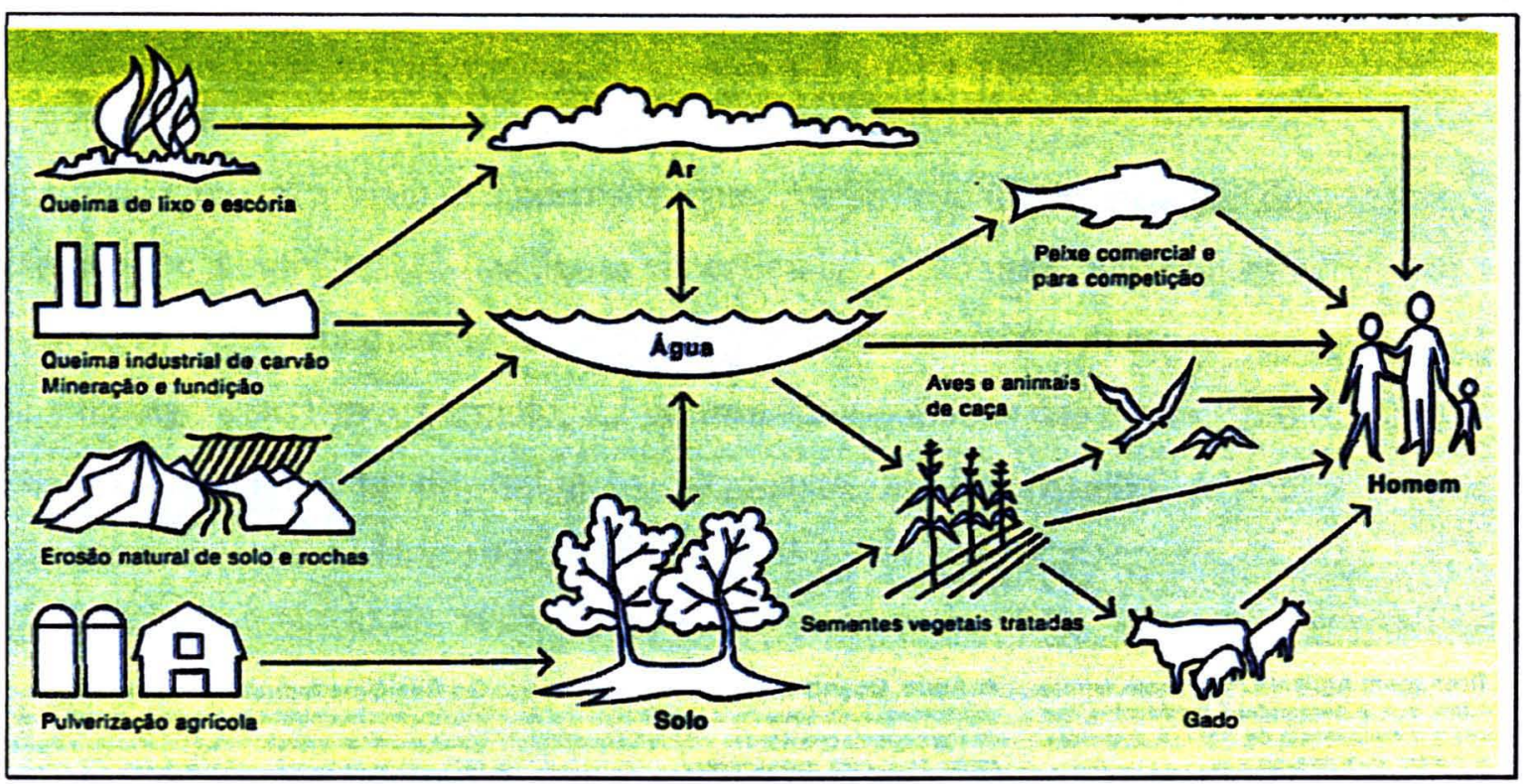

Além dos poluentes citados, a água pode vir a ser, também, condutora de organismos patogênicos, como vírus, bactérias, protozoários e vermes que, embora não habitantes naturais da água, acabam sendo albergados por esta, oriundos de poluentes de origem orgânica biodegradável, ocasionando doenças graves, dentre as quais destacam-se a hepatite, icterícia infecciosa, poliomielite, meningite asséptica, febre tifóide, cólera, leptospirose, ancilostomose, ascaridiose e esquistossomose, entre outras (ROCHA, 1995).

Outrossim, no que diz respeito à saúde das populações, é sabido que a grande causa da mortalidade infantil no Brasil está relacionada ao consumo de água sem tratamento, ou seja, a ausência de abastecimento ou o abastecimento realizado de forma irregular e deficiente dissemina a veiculação de doenças transmitidas por via hídrica (ROCHA, 1995).

\footnotetext{
${ }^{66}$ World Book (Mas Nakagawa), Enciclopédia Delta Universal, v. 12, 1982, p. 6534.
} 


\subsection{Parâmetros de controle de poluição das águas}

A qualidade da água deve atender não só à preservação e promoção da saúde pública, mas também a biota dos cursos d'água. Assim, evitar a diminuição de oxigênio disponivel e a eutrofização das águas superficiais ${ }^{67}$ é tão importante quanto evitar que a água seja condutora de substâncias cancerígenas, indutoras de teratogênese e mutagênese. Deve, portanto, ser controlada a poluição das águas tanto no que respeita à quantidade de oxigênio na massa líquida, quanto à sua contaminação química (BATALHA, 1996).

O Conselho Nacional do Meio Ambiente - CONAMA resolveu estabelecer a classificação das águas doces, salobras e salinas do Território Nacional $^{68}$, segundo seus usos preponderantes. Foram considerados os seguintes aspectos:

a) a classificação das águas doces, salobras e salinas ${ }^{69}$ essencial à defesa de seus niveis de qualidade, avaliados por paràmetros e indicadores específicos, de modo a assegurar seus usos preponderantes;

b) os custos do controle de poluição podem ser melhor adequados quando os níveis de qualidade exigidos, para um determinado corpo d'água ou seus diferentes trechos, estão de acordo com os usos ${ }^{70}$ que se pretende dar aos mesmos;

\footnotetext{
${ }^{67}$ Dependendo de sua localização, as águas são classificadas em: subterrâneas, lençóis freáticos localizados à certa profundidade do solo; superficiais, que se mostram à superficie da Terra, sendo internas, rios lagos e mares interiores; e externas, mar territorial, alto-mar e águas contíguas. (DEEBEIS, 1999. FIORILLO e RODRIGUES, 1997).

${ }^{68}$ Resolução CONAMA n ${ }^{\circ} 20$, de 18 de junho de 1986.

${ }^{69}$ Doce: desprovida de salinidade; salobra: água de salinidade inferior à oceânica; salina: água com salinidade oceânica. (FIORILLO, 2003).

${ }^{70}$ Os padrôes de qualidade (e potabilidade) da água para consumo humano se encontram mais detalhados na Portaria ${ }^{\circ} 518$, de 25/03/2004, do Ministério da Saúde.
} 
c) o enquadramento dos corpos d'água deve estar baseado não necessariamente no seu estado atual, mas nos níveis de qualidade que deveriam possuir para atender às necessidades da comunidade;

d) a saúde e o bem estar humano, bem como o equilíbrio ecológico aquático, não devem ser afetados como conseqüência da deterioração da qualidade das águas;

e) a necessidade de se criar instrumentos para avaliar a evolução da qualidade das águas em relação aos níveis estabelecidos no enquadramento, de forma a facilitar a fixação e controle de metas visando atingir gradativamente os objetivos permanentes;

f) a necessidade de reformular a classificação existente, para melhor distribuir os usos, contemplar as águas salinas e salobras e melhor especificar os parâmetros e limites associados aos niveis de qualidade requeridos, sem prejuízo de posterior aperfeiçoamento.

São as águas classificadas em nove classes, a saber:

I - Classe Especial - águas doces destinadas:

a) o abastecimento doméstico sem prévia ou com simples desinfecção;

b) à preservação do equilíbrio natural das comunidades aquáticas.

II - Classe 1 - águas doces destinadas:

a) ao abastecimento doméstico após tratamento simplificado;

b) à proteção das comunidades aquáticas;

c) à recreação de contato primário (natação, esqui aquático e mergulho); 
d) à irrigação de hortaliças que são consumidas cruas e de frutas que se desenvolvam rentes ao solo e que sejam ingeridas cruas sem remoção de película;

e) à criação natural e/ou intensiva (aquicultura) de espécies destinadas à alimentação humana.

III - Classe 2 - águas doces destinadas:

a) ao abastecimento doméstico, após tratamento convencional;

b) à proteção das comunidades aquáticas;

c) à recreação de contato primário (esqui aquático, natação e mergulho);

d) à irrigação de hortaliças e plantas frutíferas;

e) à criação natural e/ou intensivas (aquicultura) de espécies destinadas à alimentação humana.

IV - Classe 3 - águas doces destinadas:

a) ao abastecimento doméstico, após tratamento convencional;

b) à irrigação de culturas arbóreas, cerealiferas e forrageiras;

c) à dessedentação de animais.

V - Classe 4 - águas doces destinadas:

a) à navegação;

b) à harmonia paisagística;

c) aos usos menos exigentes.

VI - Classe 5 - águas salinas destinadas:

a) à recreação de contato primário;

b) à proteção das comunidades aquáticas; 
c) à criação natural e/ou intensiva (aquicultura) de espécies destinadas à alimentação humana.

VII - Classe 6 - águas salinas destinadas:
a) à navegação comercial;
b) à harmonia paisagística;
c) à recreação de contato secundário.

VIII - Classe 7 - águas salobras destinadas:
a) à recreação de contato primário;
b) à proteção das comunidades aquáticas;
c) à criação natural e/ou intensiva (aquicultura) de espécies destinadas à alimentação humana.

IX - Classe 8 - águas salobras destinadas:
a) à navegação comercial;
b) à harmonia paisagística;
c) à recreação de contato secundário.

Na Resolução CONAMA n ${ }^{\circ}$ 20/86, são adotadas as seguintes definições:

a) CLASSIFICAÇÃO: qualificação das águas doces, salobras e salinas com base nos usos preponderantes (sistema de classes de qualidade).

b) ENQUADRAMENTO: estabelecimento do nivel de qualidade (classe) a ser alcançado e/ou mantido em um segmento de corpo d'água ao longo do tempo.

c) CONDIÇÃO: qualificação do nível de qualidade apresentado por um segmento de corpo d'água, num determinado momento, em termos dos usos possiveis com segurança adequada. 
d) EFETIVAÇÃO DO ENQUADRAMENTO: conjunto de medidas necessárias para colocar e/ou manter a condição de um segmento de corpo d'água em correspondência com a sua classe.

e) ÁGUAS DOCES: águas com salinidade igual ou inferior a $0,5 \%$.

f) ÁGUAS SALOBRAS: águas com salinidade variando entre $0,5 \%$ e $30 \%$.

g) ÁGUAS SALINAS: águas com salinidade igual ou superior a 30\%.

Para as águas de classe especial, são estabelecidos os limites e/ou condições seguintes:

COLIFORMES: para o uso de abastecimento sem prévia desinfecção os coliformes totais deverão estar ausentes em qualquer amostra.

Para as águas de classe 1, são estabelecidos os limites e/ou condições seguintes:

a) materiais flutuantes, inclusive espumas não naturais: virtualmente ausentes;

b) óleos e graxas: virtualmente ausentes;

c) substâncias que comuniquem gosto ou odor: virtualmente ausentes;

d) corantes artificiais: virtualmente ausentes;

e) substâncias que formem depósitos objetáveis: virtualmente ausentes;

f) coliformes: as águas utilizadas para a irrigação de hortaliças ou plantas frutiferas que se desenvolvam rentes ao solo e que são consumidas cruas, sem remoção de casca ou película, não devem ser poluídas por excrementos humanos, ressaltando-se a necessidade de inspeções sanitárias periódicas. 
Para os demais usos, não deverá ser excedido um limite de 200 coliformes fecais por 100 mililitros em $80 \%$ ou mais de pelo menos 5 amostras mensais colhidas em qualquer mês; no caso de não haver na região meios disponiveis para o exame de coliformes fecais, o índice limite será de 1.000 coliformes totais por 100 mililitros em $80 \%$ ou mais de pelo menos 5 amostras mensais colhidas em qualquer mês.

g) $\mathrm{DBO}_{5}$ dias a $20^{\circ} \mathrm{C}$ até $3 \mathrm{mg} / \mathrm{O} \mathrm{O}_{2}$;

h) $\mathrm{OD}$, em qualquer amostra, não inferior a $6 \mathrm{mg} / \mathrm{l} \mathrm{O}_{2}$;

i) Turbidez: até 40 unidades nefelométrica de turbidez (UNT);

j) Cor: nível de cor natural do corpo de água em mg Pt/l;

1) $\mathrm{pH}: 6,0$ a 9,0 ;

m) Substâncias potencialmente prejudiciais (teores máximos):

\begin{tabular}{|l|l|l|l|}
\hline Aluminio: & 0,1 & $\mathrm{mg} / 1$ & $\mathrm{Al}$ \\
\hline Amônia não ionizável: & 0,02 & $\mathrm{mg} / 1$ & $\mathrm{NH}_{3}$ \\
\hline Arsênio: & 0,05 & $\mathrm{mg} / \mathrm{l}$ & $\mathrm{As}$ \\
\hline Bário: & 1,0 & $\mathrm{mg} / 1$ & $\mathrm{Ba}$ \\
\hline Berílio: & 0,1 & $\mathrm{mg} / 1$ & $\mathrm{Be}$ \\
\hline Boro: & 0,75 & $\mathrm{mg} / 1$ & $\mathrm{~B}$ \\
\hline Benzeno: & 0,01 & $\mathrm{mg} / 1$ & \\
\hline Benzo-a-pireno & 0,00001 & $\mathrm{mg} / \mathrm{l}$ & \\
\hline Cádmio: & 0,001 & $\mathrm{mg} / \mathrm{l}$ & $\mathrm{Cd}$ \\
\hline Cianetos: & 0,01 & $\mathrm{mg} / 1$ & $\mathrm{CN}$ \\
\hline Chumbo: & 0,03 & $\mathrm{mg} / \mathrm{l}$ & $\mathrm{Pb}$ \\
\hline Cloretos & 250 & $\mathrm{mg} / \mathrm{l}$ & $\mathrm{Cl}$ \\
\hline Cloro Residual: & 0,01 & $\mathrm{mg} / \mathrm{l}$ & $\mathrm{Cl}$ \\
\hline Cobalto: & 0,2 & $\mathrm{mg} / \mathrm{l}$ & $\mathrm{Co}$ \\
\hline Cobre: & 0,02 & $\mathrm{mg} / \mathrm{l}$ & $\mathrm{Cu}$ \\
\hline
\end{tabular}




\begin{tabular}{|c|c|c|c|}
\hline Cromo Trivalente: & 0,5 & $\mathrm{mg} / \mathrm{l}$ & $\mathrm{Cr}$ \\
\hline Cromo Hexavalente: & 0,05 & $\mathrm{mg} / \mathrm{l}$ & $\mathrm{Cr}$ \\
\hline 1,1 dicloroeteno & 0,0003 & $\mathrm{mg} / \mathrm{l}$ & \\
\hline 1,2 dicloroetano: & 0,01 & $\mathrm{mg} / 1$ & \\
\hline Estanho: & 2,0 & $\mathrm{mg} / \mathrm{l}$ & Sn \\
\hline Índice de Fenóis: & 0,001 & $\mathrm{mg} / \mathrm{l}$ & $\mathrm{C}_{6} \mathrm{H}_{5} \mathrm{OH}$ \\
\hline Ferro Solúvel: & 0,3 & $\mathrm{mg} / \mathrm{l}$ & Fé \\
\hline Fluoretos & 1,4 & $\mathrm{mg} / \mathrm{l}$ & $F$ \\
\hline Fosfato total: & 0,025 & $\mathrm{mg} / \mathrm{l}$ & $P$ \\
\hline Lítio: & 2,5 & $\mathrm{mg} / \mathrm{l}$ & $\mathrm{Li}$ \\
\hline Manganês: & 0,1 & $\mathrm{mg} / 1$ & Mn \\
\hline Mercúrio: & 0,0002 & $\mathrm{mg} / \mathrm{l}$ & $\mathrm{Hg}$ \\
\hline Niquel: & 0,025 & $\mathrm{mg} / \mathrm{l}$ & $\mathrm{Ni}$ \\
\hline Nitrato: & 10 & $\mathrm{mg} / \mathrm{l}$ & $N$ \\
\hline Nitrito: & 1,0 & $\mathrm{mg} / \mathrm{l}$ & $N$ \\
\hline Prata: & 0,01 & $\mathrm{mg} / \mathrm{l}$ & $\mathrm{Ag}$ \\
\hline Pentaclorofenol: & 0,01 & $\mathrm{mg} / \mathrm{l}$ & \\
\hline Selênio: & 0,01 & $\mathrm{mg} / \mathrm{l}$ & $\mathrm{Se}$ \\
\hline Sólidos dissolvidos totais: & 500 & $\mathrm{mg} / \mathrm{l}$ & \\
\hline \multicolumn{4}{|l|}{ Subs. tenso-ativas que reagem } \\
\hline com o azul de metileno: & 0,5 & $\mathrm{mg} / \mathrm{l}$ & LAS \\
\hline Sulfatos: & 250 & $\mathrm{mg} / \mathrm{l}$ & $\mathrm{SO}_{4}$ \\
\hline Sulfetos ( $\mathrm{H}_{2} \mathrm{~S}$ não dissociado): & 0,002 & $\mathrm{mg} / \mathrm{l}$ & $s$ \\
\hline Tetracloroeteno: & 0,01 & $\mathrm{mg} / \mathrm{l}$ & \\
\hline Tricloroeteno: & 0,03 & $\mathrm{mg} / \mathrm{l}$ & \\
\hline Tetracloreto de carbono: & 0,003 & $\mathrm{mg} / \mathrm{l}$ & \\
\hline 2,4,6 triclorofenol: & 0,01 & $\mathrm{mg} / \mathrm{l}$ & \\
\hline Urânio total: & 0,02 & $\mathrm{mg} / \mathrm{l}$ & $U$ \\
\hline Vanádio: & 0,1 & $\mathrm{mg} / \mathrm{l}$ & V \\
\hline Zinco: & 0,18 & $\mathrm{mg} / \mathrm{l}$ & $\mathrm{Zn}$ \\
\hline
\end{tabular}




\begin{tabular}{|l|l|l|l|}
\hline Aldrin: & 0,01 & $\mathrm{ug} / 1$ & \\
\hline Clordano: & 0,04 & $\mathrm{ug} / 1$ & \\
\hline DDT: & 0,002 & $\mathrm{ug} / 1$ & \\
\hline Dieldrin: & 0,005 & $\mathrm{ug} / 1$ & \\
\hline Endrin: & 0,004 & $\mathrm{ug} / 1$ & \\
\hline Endossulfan: & 0,056 & $\mathrm{ug} / 1$ & \\
\hline Epóxido de heptacloro: & 0,01 & $\mathrm{ug} / 1$ & \\
\hline Heptacloro: & 0,01 & $\mathrm{ug} / 1$ & \\
\hline Lindano (gama-BHC): & 0,02 & $\mathrm{ug} / 1$ & \\
\hline Metoxicloro: & 0,03 & $\mathrm{ug} / 1$ & \\
\hline Dodecacloro+Nonacloro: & 0,001 & $\mathrm{ug} / 1$ & \\
\hline Bifenilas Policloradas (PCB's): & 0,001 & $\mathrm{ug} / 1$ & \\
\hline Toxafeno: & 0,01 & $\mathrm{ug} / 1$ & \\
\hline Demeton: & 0,1 & $\mathrm{ug} / 1$ & \\
\hline Gution: & 0,005 & $\mathrm{ug} / 1$ & \\
\hline Malation: & 0,1 & $\mathrm{ug} / 1$ & \\
\hline Paration: & 0,04 & $\mathrm{ug} / 1$ & \\
\hline Carbaril: & 0,02 & $\mathrm{ug} / 1$ & \\
\hline $\begin{array}{l}\text { Compostos } \\
\text { carbamatos totais: }\end{array}$ & 4,0 & $\mathrm{ug} / 1$ & Paration \\
\hline 2,4 - D: & 10,0 & $\mathrm{ug} / 1$ & \\
\hline $2,4,5$ - TP: & 2,0 & $\mathrm{ug} / 1$ & \\
\hline $2,4,5$ - T: & & & \\
\hline
\end{tabular}

Para as águas de Classe 2, são estabelecidos os mesmos limites ou condições da Classe 1 , à exceção dos seguintes:

a) não será permitida a presença de corantes artificiais que não sejam removiveis por processo de coagulação, sedimentação e filtração convencionais; 
b) Coliformes: não deverá ser excedido um limite de 1.000 coliformes fecais por 100 mililitros em $80 \%$ ou mais de pelo menos 5 amostras mensais; no caso de não haver meios disponíveis para o exame de coliformes fecais, o indice limite será de até 5.000 coliformes totais por 100 mililitros em $80 \%$ ou mais de pelo menos 5 amostras mensais colhidas em qualquer mês;

c) Cor: até $75 \mathrm{mg} \mathrm{Pt} / 1$;

d) Turbidez: até 100 UNT;

e) $\mathrm{DBO}_{5}$ dias a $20^{\circ} \mathrm{C}$ até $5 \mathrm{mg} / 1 \mathrm{O}_{2}$;

f) $\mathrm{OD}$, em qualquer amostra, não inferior a $5 \mathrm{mg} / \mathrm{l} \mathrm{O}_{2}$.

Para as águas de Classe 3 são estabelecidos os limites ou condições seguintes:

a) materiais flutuantes, inclusive espumas não naturais: virtualmente ausentes;

b) óleos e graxas: virtualmente ausentes;

c) substâncias que comuniquem gosto ou odor: virtualmente ausentes;

d) não será permitida a presença de corantes artificiais que não sejam removiveis por processo de coagulação, sedimentação e filtração convencionais;

e) substâncias que formem depósitos objetáveis: virtualmente ausentes;

f) $\mathrm{DBO}_{5}$ dias a $20^{\circ} \mathrm{C}$ até $10 \mathrm{mg} / 1 \mathrm{O}_{2}$;

g) OD, em qualquer amostra, não inferior a $4 \mathrm{mg} / \mathrm{l} \mathrm{O}_{2}$;

h) Turbidez: até 100 UNT; 
i) Cor: até $75 \mathrm{mg} \mathrm{Pt} / \mathrm{l}$;

j) número de coliformes fecais até 4.000 por 100 mililitros em $80 \%$ ou mais de pelo menos 5 amostras mensais colhidas em qualquer mês; no caso de não haver, na região, meios disponíveis para o exame de coliformes fecais, o indice limite será de até 20.000 coliformes totais por 100 mililitros em $80 \%$ ou mais de pelo menos 5 amostras mensais colhidas em qualquer mês;

1) $\mathrm{pH}: 6,0$ a 9,0 ;

m) Substâncias potencialmente prejudiciais (teores máximos):

\begin{tabular}{|l|l|l|l|}
\hline Alumínio: & 0,1 & $\mathrm{mg} / \mathrm{Al}$ \\
\hline Arsênio: & 0,05 & $\mathrm{mg} / 1$ & $\mathrm{As}$ \\
\hline Bário: & 1,0 & $\mathrm{mg} / 1$ & $\mathrm{Ba}$ \\
\hline Berílio: & 0,1 & $\mathrm{mg} / 1$ & $\mathrm{Be}$ \\
\hline Boro: & 0,75 & $\mathrm{mg} / 1$ & $\mathrm{~B}$ \\
\hline Benzeno: & 0,01 & $\mathrm{mg} / 1$ & \\
\hline Benzo-a-pireno: & 0,00001 & $\mathrm{mg} / 1$ & \\
\hline Cádmio: & 0,01 & $\mathrm{mg} / 1$ & $\mathrm{Cd}$ \\
\hline Cianetos: & 0,2 & $\mathrm{mg} / 1$ & $\mathrm{CN}$ \\
\hline Chumbo: & 0,05 & $\mathrm{mg} / 1$ & $\mathrm{~Pb}$ \\
\hline Cloretos: & 250 & $\mathrm{mg} / 1$ & $\mathrm{Cl}$ \\
\hline Cobalto: & 0,2 & $\mathrm{mg} / 1$ & $\mathrm{Co}$ \\
\hline Cobre: & 0,5 & $\mathrm{mg} / 1$ & $\mathrm{Cu}$ \\
\hline Cromo Trivalente: & 0,5 & $\mathrm{mg} / 1$ & $\mathrm{Cr}$ \\
\hline Cromo Hexavalente: & 0,05 & $\mathrm{mg} / 1$ & $\mathrm{Cr}$ \\
\hline 1,1 dicloroeteno: & 0,0003 & $\mathrm{mg} / 1$ & \\
\hline 1,2 dicloroetano: & 0,01 & $\mathrm{mg} / 1$ & \\
\hline Estanho: & 2,0 & $\mathrm{mg} / 1$ & $\mathrm{Sn}$ \\
\hline Índice de Fenóis: & 0,3 & $\mathrm{mg} / 1$ & $\mathrm{C} 6 \mathrm{H}_{5} \mathrm{OH}$ \\
\hline Ferro solúvel: & 5,0 & $\mathrm{mg} / 1$ & $\mathrm{Fe}$ \\
\hline
\end{tabular}




\begin{tabular}{|c|c|c|c|}
\hline Fluoretos: & 1,4 & $\mathrm{mg} / 1$ & $\mathrm{~F}$ \\
\hline Fosfato total: & 0,025 & $\mathrm{mg} / \mathrm{l}$ & $P$ \\
\hline Lítio: & 2,5 & $\mathrm{mg} / \mathrm{l}$ & $\mathrm{Li}$ \\
\hline Manganês: & 0,5 & $\mathrm{mg} / \mathrm{l}$ & $\mathrm{Mn}$ \\
\hline Mercúrio: & 0,002 & $\mathrm{mg} / \mathrm{l}$ & $\mathrm{Hg}$ \\
\hline Níquel: & 0,025 & $\mathrm{mg} / \mathrm{l}$ & $\mathrm{Ni}$ \\
\hline Nitrato: & 10 & $\mathrm{mg} / \mathrm{l}$ & $\mathrm{N}$ \\
\hline Nitrito: & 1,0 & $\mathrm{mg} / \mathrm{l}$ & $\mathrm{N}$ \\
\hline Nitrogênio Amoniacal: & 1,0 & $\mathrm{mg} / 1$ & $N$ \\
\hline Prata: & 0,05 & $\mathrm{mg} / \mathrm{l}$ & $\mathrm{Ag}$ \\
\hline Pentaclorofenol: & 0,01 & $\mathrm{mg} / \mathrm{l}$ & \\
\hline Selênio: & 0,01 & $\mathrm{mg} / \mathrm{l}$ & Se \\
\hline Sólidos dissolvidos totais: & 500 & $\mathrm{mg} / \mathrm{l}$ & \\
\hline \multicolumn{4}{|l|}{ Substâncias tenso-ativas que reagem } \\
\hline com o azul de metileno: & 0,5 & $\mathrm{mg} / \mathrm{l}$ & LAS \\
\hline Sulfatos: & 250 & $\mathrm{mg} / \mathrm{l}$ & $\mathrm{SO}_{4}$ \\
\hline Sulfatos (como $\mathrm{H}_{2} \mathrm{~S}$ não dissociado): & 0,3 & $\mathrm{mg} / \mathrm{l}$ & $S$ \\
\hline Tetracloroeteno: & 0,01 & $\mathrm{mg} / \mathrm{l}$ & \\
\hline Tricloroeteno & 0,03 & $\mathrm{mg} / \mathrm{l}$ & \\
\hline Tetracloreto de Carbono & 0,003 & $\mathrm{mg} / \mathrm{l}$ & \\
\hline $2,4,6$ triclorofenol: & 0,01 & $\mathrm{mg} / \mathrm{l}$ & \\
\hline Urânio Total: & 0,02 & $\mathrm{mg} / \mathrm{l}$ & $U$ \\
\hline Vanádio: & 0,1 & $\mathrm{mg} / \mathrm{l}$ & V \\
\hline Zinco: & 5,0 & $\mathrm{mg} / \mathrm{l}$ & $\mathrm{Zn}$ \\
\hline Aldrin: & 0,03 & $\mathrm{ug} / \mathrm{l}$ & \\
\hline Clordano: & 0,3 & $\mathrm{ug} / \mathrm{l}$ & \\
\hline DDT: & 1,0 & $\mathrm{ug} / \mathrm{l}$ & \\
\hline Dieldrin: & 0,03 & $u g / 1$ & \\
\hline Endrin: & 0,2 & ug/l & \\
\hline Endossulfan: & 150 & $\mathrm{ug} / \mathrm{I}$ & \\
\hline
\end{tabular}




\begin{tabular}{|l|l|l|l|}
\hline Epóxido de Heptacloro: & 0,1 & $\mathrm{ug} / 1$ & \\
\hline Heptacloro: & 0,1 & $\mathrm{ug} / 1$ & \\
\hline Lindano (gama-BHC): & 3,0 & $\mathrm{ug} / 1$ & \\
\hline Metoxicloro: & 30,0 & $\mathrm{ug} / 1$ & \\
\hline Dodecacloro+Nonacloro: & 0,001 & $\mathrm{ug} / 1$ & \\
\hline Bifenilas Policloradas (PCB's): & 0,001 & $\mathrm{ug} / 1$ & \\
\hline Toxafeno: & 5,0 & $\mathrm{ug} / 1$ & \\
\hline Demeton: & 14,0 & $\mathrm{ug} / 1$ & \\
\hline Gution: & 0,005 & $\mathrm{ug} / 1$ & \\
\hline Malation: & 100,0 & $\mathrm{ug} / 1$ & \\
\hline Paration: & 35,0 & $\mathrm{ug} / 1$ & \\
\hline Carbaril: & 70,0 & $\mathrm{ug} / 1$ & \\
\hline $\begin{array}{l}\text { Compostos } \\
\text { carbamatos totais }\end{array}$ & 100,0 & $\mathrm{ug} / 1$ & Paration \\
\hline 2,4 - D: & 20,0 & $\mathrm{ug} / 1$ & \\
\hline $2,4,5$ - TP: & 10,0 & $\mathrm{ug} / 1$ & \\
\hline $2,4,5$ - T: & 2,0 & $\mathrm{ug} / 1$ & \\
\hline
\end{tabular}

Para as águas de Classe 4, são estabelecidos os limites ou condições seguintes:

a) materiais flutuantes, inclusive espumas não naturais: virtualmente ausentes;

b) odor e aspecto: não objetáveis;

c) óleos e graxas: toleram-se iridicências;

d) substâncias facilmente sedimentáveis que contribuam para o assoreamento de canais de navegação: virtualmente ausentes;

e) índice de fenóis até $1,0 \mathrm{mg} / 1 \mathrm{C}_{6} \mathrm{H}_{5} \mathrm{OH}$; 
f) OD superior a $2,0 \mathrm{mg} / \mathrm{l} \mathrm{O}_{2}$, em qualquer amostra;

g) $\mathrm{pH}: 6$ a 9 .

Para as águas de Classe 5, são estabelecidos os limites ou condições seguintes:

a) materiais flutuantes: virtualmente ausentes;

b) óleos e graxas: virtualmente ausentes;

c) substâncias que produzem odor e turbidez: virtualmente ausentes;

d) corantes artificiais: virtualmente ausentes;

e) substâncias que formem depósitos objetáveis: virtualmente ausentes;

f) coliformes: para o uso de criação natural e/ou intensiva de espécies destinadas à alimentação humana e que serão ingeridas cruas, não deverá ser excedida uma concentração média de 14 coliformes fecais por 100 mililitros, com não mais de $10 \%$ das amostras excedendo 43 coliformes fecais por 100 mililitros. Para os demais usos não deverá ser excedido um limite de 1.000 coliformes fecais por 100 mililitros em $80 \%$ ou mais de pelo menos 5 amostras mensais colhidas em qualquer mês; no caso de não haver, na região, meios disponiveis para o exame de coliformes fecais, o índice limite será de até 5.000 coliformes totais por 100 mililitros em $80 \%$ ou mais de pelo menos 5 amostras mensais colhidas em qualquer mês;

g) $\mathrm{DBO}_{5}$ dias a $20^{\circ} \mathrm{C}$ até $5 \mathrm{mg} / \mathrm{l} \mathrm{O}_{2}$;

h) $\mathrm{OD}$, em qualquer amostra, não inferior a $6 \mathrm{mg} / 1 \mathrm{O}_{2}$;

i) $\mathrm{pH}: 6,5$ a 8,5, não devendo haver uma mudança do $\mathrm{pH}$ natural maior do que 0,2 unidade; 
j) substâncias potencialmente prejudiciais (teores máximos):

\begin{tabular}{|c|c|c|c|}
\hline Aluminio: & 1,5 & $\mathrm{mg} / \mathrm{l}$ & $\mathrm{Al}$ \\
\hline Amônia não ionizável: & 0,4 & $\mathrm{mg} / \mathrm{l}$ & $\mathrm{NH}_{3}$ \\
\hline Arsênio: & 0,05 & $\mathrm{mg} / \mathrm{l}$ & As \\
\hline Bário: & 1,0 & $\mathrm{mg} / \mathrm{l}$ & $\mathrm{Ba}$ \\
\hline Berilio: & 1,5 & $\mathrm{mg} / \mathrm{l}$ & $\mathrm{Be}$ \\
\hline Boro: & 5,0 & $\mathrm{mg} / \mathrm{l}$ & B \\
\hline Cádmio: & 0,005 & $\mathrm{mg} / \mathrm{l}$ & $\mathrm{Cd}$ \\
\hline Chumbo: & 0,01 & $\mathrm{mg} / \mathrm{l}$ & $\mathrm{Pb}$ \\
\hline Cianetos: & 0,005 & $\mathrm{mg} / \mathrm{l}$ & $\mathrm{CN}$ \\
\hline Cloro residual: & 0,01 & $\mathrm{mg} / \mathrm{l}$ & $\mathrm{Cl}$ \\
\hline Cobre: & 0,05 & $\mathrm{mg} / \mathrm{l}$ & $\mathrm{Cu}$ \\
\hline Cromo Hexavalente: & 0,05 & $\mathrm{mg} / \mathrm{l}$ & $\mathrm{Cr}$ \\
\hline Estanho: & 2,0 & $\mathrm{mg} / \mathrm{l}$ & Sn \\
\hline Índice de fenóis: & 0,001 & $\mathrm{mg} / \mathrm{l}$ & $\mathrm{C}_{6} \mathrm{H}_{5} \mathrm{OH}$ \\
\hline Ferro: & 0,3 & $\mathrm{mg} / \mathrm{l}$ & $\mathrm{Fe}$ \\
\hline Fluoretos: & 1,4 & $\mathrm{mg} / \mathrm{l}$ & $F$ \\
\hline Manganês: & 0,1 & $\mathrm{mg} / \mathrm{l}$ & Mn \\
\hline Mercúrio: & 0,0001 & $\mathrm{mg} / \mathrm{l}$ & $\mathrm{Hg}$ \\
\hline Niquel: & 0,1 & $\mathrm{mg} / \mathrm{l}$ & $\mathrm{Ni}$ \\
\hline Nitrato: & 10,0 & $\mathrm{mg} / \mathrm{l}$ & $N$ \\
\hline Nitrito: & 1,0 & $\mathrm{mg} / \mathrm{l}$ & $N$ \\
\hline Prata: & 0,005 & $\mathrm{mg} / \mathrm{l}$ & $\mathrm{Ag}$ \\
\hline Selênio: & 0,01 & $\mathrm{mg} / \mathrm{l}$ & $\mathrm{Se}$ \\
\hline $\begin{array}{l}\text { Substâncias tensoativas que reagem com } \\
\text { o azul de metileno: }\end{array}$ & 0,5 & $\mathrm{mg} / \mathrm{l}$ & LAS \\
\hline Sulfetos com $\mathrm{H}_{2} \mathrm{~S}$ : & 0,002 & $\mathrm{mg} / \mathrm{l}$ & $\mathrm{S}$ \\
\hline Tálio: & 0,1 & $\mathrm{mg} / \mathrm{l}$ & TI \\
\hline Urânio Total: & 0,5 & $\mathrm{mg} / \mathrm{l}$ & $\mathrm{U}$ \\
\hline Zinco: & 0,17 & $\mathrm{mg} / \mathrm{l}$ & $\mathrm{Zn}$ \\
\hline
\end{tabular}




\begin{tabular}{|l|l|l|l|}
\hline Aldrin: & 0,003 & $\mathrm{ug} / 1$ & \\
\hline Clordano: & 0,004 & $\mathrm{ug} / 1$ & \\
\hline DDT: & 0,001 & $\mathrm{ug} / 1$ & \\
\hline Demeton: & 0,1 & $\mathrm{ug} / 1$ & \\
\hline Dieldrin: & 0,003 & $\mathrm{ug} / 1$ & \\
\hline Endossulfan: & 0,034 & $\mathrm{ug} / 1$ & \\
\hline Endrin: & 0,004 & $\mathrm{ug} / 1$ & \\
\hline Epóxido de Heptacloro: & 0,001 & $\mathrm{ug} / 1$ & \\
\hline Heptacloro: & 0,001 & $\mathrm{ug} / 1$ & \\
\hline Metoxicloro: & 0,03 & $\mathrm{ug} / 1$ & \\
\hline Lindano (gama-BHC): & 0,004 & $\mathrm{ug} / 1$ & \\
\hline Dodecacloro+Nonacloro: & 0,001 & $\mathrm{ug} / 1$ & \\
\hline Gution: & 0,01 & $\mathrm{ug} / 1$ & \\
\hline Malation: & 0,1 & $\mathrm{ug} / 1$ & \\
\hline Paration: & 0,04 & $\mathrm{ug} / 1$ & \\
\hline Toxafeno: & 0,005 & $\mathrm{ug} / 1$ & \\
\hline $\begin{array}{l}\text { Compostos } \\
\text { carbamatos totais: }\end{array}$ & 10,0 & $\mathrm{ug} / 1$ & $\mathrm{em}$ Paration \\
\hline 2,4 - D: & 10,0 & $\mathrm{ug} / 1$ & \\
\hline $2,4,5$ - TP: & 10,0 & $\mathrm{ug} / 1$ & \\
\hline $2,4,5$ - T: & 10,0 & $\mathrm{ug} / 1$ & \\
\hline & & & \\
\hline
\end{tabular}

Para as águas de Classe 6, são estabelecidos os limites ou condições seguintes:
a) materiais flutuantes: virtualmente ausentes;
b) óleos e graxas: toleram-se iridicências; 
c) substâncias que produzem odor e turbidez: virtualmente ausentes;

d) corantes artificiais: virtualmente ausentes;

e) substâncias que formem depósitos objetáveis: virtualmente ausentes;

f) coliformes: não deverá ser excedido um limite de 4.000 coliformes fecais por $100 \mathrm{ml}$ em $80 \%$ ou mais de pelo menos 5 amostras mensais colhidas em qualquer mês; no caso de não haver na região meio disponível para o exame de coliformes fecais, o índice limite será de 20.000 coliformes totais por 100 mililitros em $80 \%$ ou mais de pelo menos 5 amostras mensais colhidas em qualquer mês;

g) $\mathrm{DBO}_{5}$ dias a $20^{\circ} \mathrm{C}$ até $10 \mathrm{mg} / \mathrm{lO}_{2}$;

h) $\mathrm{OD}$, em qualquer amostra, não inferior a $4 \mathrm{mg} / 1 \mathrm{O}_{2}$;

i) $\mathrm{pH}: 6,5$ a 8,5 , não devendo haver uma mudança do $\mathrm{pH}$ natural maior do que 0,2 unidades.

Para as águas de Classe 7, são estabelecidos os limites ou condições seguintes:

a) $\mathrm{DBO}_{5}$ dias a $20^{\circ} \mathrm{C}$ até $5 \mathrm{mg} / \mathrm{l} \mathrm{O}_{2}$;

b) $\mathrm{OD}$, em qualquer amostra, não inferior a $5 \mathrm{mg} / \mathrm{O}_{2}$;

c) $\mathrm{pH}: 6,5$ a 8,5 ;

d) óleos e graxas: virtualmente ausentes;

e) materiais flutuantes: virtualmente ausentes;

f) substâncias que produzem cor, odor e turbidez: virtualmente ausentes;

g) substâncias que formem depósitos objetáveis: virtualmente ausentes;

h) coliformes: para o uso de criação natural e/ou intensiva de espécies destinadas à alimentação humana e que serão ingeridas cruas, não deverá ser excedido uma concentração média de 14 coliformes fecais por 100 mililitros com não mais de $10 \%$ das amostras excedendo 43 coliformes fecais por 100 mililitros. 
Para os demais usos não deverá ser excedido um limite de 1.000 coliformes fecais por 100 mililitros em $80 \%$ ou mais de pelo menos 5 amostras mensais, colhidas em qualquer mês; no caso de não haver na região, meios disponiveis para o exame de coliformes fecais, o índice limite será de até 5.000 coliformes totais por 100 mililitros em $80 \%$ ou mais de pelo menos 5 amostras mensais, colhidas em qualquer mês;

i) substâncias potencialmente prejudiciais (teores máximos):

\begin{tabular}{|l|l|l|l|}
\hline Amônia: & 0,4 & $\mathrm{mg} / \mathrm{l}$ & $\mathrm{N}$ \\
\hline Arsênio: & 0,05 & $\mathrm{mg} / \mathrm{l}$ & $\mathrm{As}$ \\
\hline Cádmio: & 0,005 & $\mathrm{mg} / \mathrm{l}$ & $\mathrm{Cd}$ \\
\hline Cianetos: & 0,005 & $\mathrm{mg} / 1$ & $\mathrm{CN}$ \\
\hline Chumbo: & 0,01 & $\mathrm{mg} / 1$ & $\mathrm{~Pb}$ \\
\hline Cobre: & 0,05 & $\mathrm{mg} / 1$ & $\mathrm{Cu}$ \\
\hline Cromo hexavalente: & 0,05 & $\mathrm{mg} / 1$ & $\mathrm{Cr}$ \\
\hline Índice de fenóis: & 0,001 & $\mathrm{mg} / 1$ & $\mathrm{C} 6 \mathrm{H}_{5} \mathrm{OH}$ \\
\hline Fluoretos: & 1,4 & $\mathrm{mg} / 1$ & $\mathrm{~F}$ \\
\hline Mercúrio: & 0,0001 & $\mathrm{mg} / 1$ & $\mathrm{Hg}$ \\
\hline Niquel: & 0,1 & $\mathrm{mg} / 1$ & $\mathrm{Ni}$ \\
\hline Sulfetos como $\mathrm{H}_{2} \mathrm{~S}:$ & 0,002 & $\mathrm{mg} / 1$ & $\mathrm{~S}$ \\
\hline Zinco: & 0,17 & $\mathrm{mg} / 1$ & $\mathrm{Zn}$ \\
\hline Aldrin: & 0,003 & $\mathrm{ug} / 1$ & \\
\hline Clordano: & 0,004 & $\mathrm{ug} / 1$ & \\
\hline DDT: & 0,001 & $\mathrm{ug} / \mathrm{l}$ & \\
\hline Demeton: & 0,1 & $\mathrm{ug} / \mathrm{l}$ & \\
\hline Dieldrin: & 0,003 & $\mathrm{ug} / \mathrm{l}$ & \\
\hline Endrin: & 0,004 & $\mathrm{ug} / 1$ & \\
\hline Endossulfan: & 0,034 & $\mathrm{ug} / \mathrm{l}$ & \\
\hline
\end{tabular}




\begin{tabular}{|l|l|l|l|}
\hline Epóxido de heptacloro: & 0,001 & $\mathrm{ug} / 1$ & \\
\hline Gution: & 0,01 & $\mathrm{ug} / 1$ & \\
\hline Heptacloro: & 0,001 & $\mathrm{ug} / 1$ & \\
\hline Lindano (gama - BHC): & 0,004 & $\mathrm{ug} / 1$ & \\
\hline Malation: & 0,1 & $\mathrm{ug} / 1$ & \\
\hline Metoxicloro: & 0,03 & $\mathrm{ug} / 1$ & \\
\hline Dodecacloro+Nonacloro: & 0,001 & $\mathrm{ug} / 1$ & \\
\hline Paration: & 0,04 & $\mathrm{ug} / 1$ & \\
\hline Toxafeno: & 0,005 & $\mathrm{ug} / 1$ & \\
\hline $\begin{array}{l}\text { Compostos organofosforados } \\
\text { carbamatos totais: }\end{array}$ & 10,0 & $\mathrm{ug} / 1$ & $\mathrm{em}$ Paration \\
\hline 2,4 - D: & 10,0 & $\mathrm{ug} / 1$ & \\
\hline $2,4,5$ - T: & 10,0 & $\mathrm{ug} / 1$ & \\
\hline $2,4,5$ - TP: & 10,0 & $\mathrm{ug} / 1$ & \\
\hline
\end{tabular}

Para as águas de Classe 8, são estabelecidos os limites ou condições seguintes:
a) $\mathrm{pH}: 5$ a 9 ;
b) $\mathrm{OD}$, em qualquer amostra, não inferior a $3,0 \mathrm{mg} / 1 \mathrm{O}_{2}$;
c) óleos e graxas: toleram-se iridicências;
d) materiais flutuantes: virtualmente ausentes;
e) substâncias que produzam cor, odor e turbidez: virtualmente ausentes;
f) substâncias facilmente sedimentáveis que contribuam para o assoreamento de canais de navegação: virtualmente ausentes;
g) coliformes: não deverá ser excedido um limite de 4.000 coliformes fecais por $100 \mathrm{ml} \mathrm{em} 80 \%$ ou mais de pelo menos 5 amostras mensais colhidas em qualquer mês; no caso de não haver, na região, meios disponíveis para o exame de coliformes fecais, o índice será de 20.000 coliformes totais por 100 mililitros em $80 \%$ ou mais de pelo menos 5 amostras mensais colhidas em qualquer mês.


Os padrões de qualidade das águas estabelecidos na Resolução CONAMA $n^{\circ} 20 / 86$, constituem-se em limites individuais para cada substância. Considerando eventuais ações sinergéticas entre as mesmas, estas ou outras não especificadas, não poderão conferir às águas características capazes de causarem efeitos letais ou alteração de comportamento, reprodução ou fisiologia da vida.

Os métodos de coleta e análise das águas devem ser os especificados nas normas aprovadas pelo Instituto Nacional de Metrologia, Normalização e Qualidade Industrial - INMETRO ou, na ausência delas, no Standard Methods for the Examination of Water and Wastewater - APHA-AWWA-WPCF, última edição, ressalvado o disposto no Artigo 12. O índice de fenóis deverá ser determinado conforme o método 510B do Standard Methods for the Examination of Water and WasterWater.

Os Estados, Territórios e o Distrito Federal, através dos respectivos órgãos de controle ambiental, deverão exercer sua atividade orientadora, fiscalizadora e punitiva das atividades potencialmente poluidoras instaladas em seu território, ainda que os corpos de água prejudicados não sejam de seu domínio ou jurisdição.

Importante ressaltar que os padrões de qualidade da água variam muito de região para região, dependendo do nível de aceitabilidade de cada população, que, por sua vez, é definido pela disponibilidade econômica e, em conseqüência, pela qualidade relativa à continuidade no serviço de abastecimento de água àquela população. $^{71}$

\footnotetext{
${ }^{71}$ Os "Padróes Internacionais de Água Potável" e os "Padróes Europeus de Água Potável", publicados pela Organização Mundial de Saúde, estabelecem limites rígidos para algumas substâncias, como o chumbo, o mercúrio e o selênio, e para outras substâncias e características são estabelecidos limites "aceitáveis" (referem-se às águas aceitáveis pelo consumidor) e limites "admissíveis ou excessivos" (referem-se às águas impróprias para o consumo). Nessas aferiçðes são considerados: sólidos totais, cor, turbidez, sabor, odor, ferro, manganês, cobre, zinco, cálcio, sulfato, cloretos, pH, magnésio, compostos fenólicos, ácido sulfidrico, fluoretos, nitratos, detergentes aniônicos, amônia, gás carbônico livre, oxigênio dissolvido e dureza total (BRANCO e ROCHA, 1977).
} 


\begin{abstract}
"A interdependência das nações e a solidariedade que envolve todo o gênero humano são fatos evidentes no mundo contemporâneo. O mundo tornou-se um só. Não é mais possivel isolarmo-nos dos homens que vivem em outros Estados e em outras partes do globo. Suas maneiras de ver e de agir, sua opulência ou miséria, condicionam nosso destino." 72
\end{abstract}

\title{
4. OS INSTRUMENTOS INTERNACIONAIS DE PROTEÇĀO AMBIENTAL
}

\subsection{O direito nas diferentes nações do mundo}

O estudo dos diversos Sistemas Jurídicos existentes é, por essência, o estudo comparativo das diversas formas em que se aprenda o direito, consideradas as divergências de língua, usos, costumes, história, desenvolvimento econômico, localização geográfica, etnia, enfim, considerados todos os fatores que influenciam os povos, nos diferentes momentos de sua história.

Estudar o Direito Comparado e os diversos Sistemas Jurídicos conhecidos é de interesse não só para os chamados comparatistas, mas a todos juristas que buscam o aperfeiçoamento da aplicação do direito nas relações sociais.

\footnotetext{
${ }^{72} \mathrm{O}$ mundo atual impõe, tanto aos políticos quanto aos economistas e aos juristas, uma nova visão dos problemas que lhes dizem respeito. Independentemente de qualquer preocupação acadêmica, as necessidades práticas exigem o conhecimento dos direitos estrangeiros. A movimentação das pessoas, das mercadorias, dos capitais tende, cada vez mais, a ignorar as fronteiras dos Estados. As relações internacionais ganharam, em todos os domínios, uma importância que aumenta a cada ano. A edificação de uma ordem jurídica que convenha a estas relações é uma tarefa que não pode ser realizada se as autoridades nacionais, com a falsa idéia de sua onipotência, ignoram o direito estrangeiro. A simples preocupação com a coexistência e, mais ainda, o estabelecimento da indispensável cooperação internacional, exigem que nos voltemos para os direitos estrangeiros. (DAVID, 1998).
} 
ARISTÓTELES, em sua obra Poética, bem descreveu a arte de imitar e sua grande valia para o aprendizado humano ${ }^{73}$. O estudo dos Sistemas Jurídicos, através da ciência do Direito Comparado, não deixa de ser, também, uma forma de imitação, onde encontramos da contemplação da imagem gerada por outros Sistemas de Direito, uma melhor aplicabilidade para as questões semelhantes em nosso sistema vigente. $E$, se valioso é o resultado dos estudos realizados entre os diversos Sistemas do Direito Contemporâneo, não menos importante é o legado pelos Sistemas Jurídicos já ultrapassados pelo progresso da humanidade e do aperfeiçoamento das relações sociais.

Durante séculos a ciência do direito ocupou-se com estudos de um direito justo, originário da vontade de Deus, da natureza, ou da própria razão humana. Os estudos tomavam por base, exclusivamente, o direito romano e o direito canônico, refletindo o pensamento cristão como elemento central do direito comum do mundo civilizado, conhecido até então. Nos séculos XV e XVI, muito embora as grandes descobertas geográficas tenham assinalado, oficialmente, o inicio da Época Moderna, o direito permaneceu às margens dos grandes acontecimentos culturais daqueles séculos. Tanto o Renascimento quanto a Reforma Protestante, continuaram a operar em torno dos esquemas herdados do direito romano; a concepção do direito existente ainda era para regular as novidades na realidade econòmica, advindas com o descobrimento das novas terras.

É somente com o Iluminismo, no final do século XVIII, que tem início a Era Moderna para o direito, a tradição romanista é profundamente alterada com as novas relações de produção.

\footnotetext{
73 "O imitar é congênito no homem (e nisso difere dos outros viventes, pois, por imitação aprende as primeiras noçōes), e os homens se comprazem no imitado... Causa é que o aprender não só muito apraz aos filósofos, mas também, igualmente, aos demais homens, se bem que menos participem dele. Efetivamente, tal é o motivo porque se deleitam perante as imagens: olhando-as, aprendem e discorrem sobre o que seja cada uma delas" (in Os Pensadores, 1973, p. 445)
} 
A polêmica gerada contra o direito romano interrompeu a continuidade jurídica reinante até então e, em conseqüência, originou sua substituição pelas codificações européias. Com Frederico, o Grande, a Prússia passa a ser regida pelo Allgemeines Landrecht e por um código criminal; e, com a Revolução Francesa, a França reina sob a legislação napoleônica, cujas idéias que a originaram, ainda encontram-se presentes nos direitos positivos atualmente vigentes. Com a revolução cultural desencadeada no século XIX, houve a desmistificação do direito "universal" que culminou com a destruição desse jus commune, substituido pelas codificações nacionais. As leis criadas a partir dessa nova ótica do direito, passaram, então, a ser objeto fundamental de estudo nas universidades. Toda essa revolução originou um movimento de nacionalização do direito, com a criação de leis nacionais que visavam, principalmente, fomentar o descrédito das leis naturais existentes. $\mathrm{O}$ desenvolvimento do direito comparado deu-se, mais especificamente, numa reação a essa nacionalização, pois as relações internacionais e a própria busca por uma lei ideal, impulsionaram, progressivamente, à comparação das diversas leis, inicialmente da Europa, e hoje do mundo como um todo.

Nos aspectos histórico, filosófico e da teoria geral do direito, somente a partir do século XIX, o direito comparado passou a ser reconhecido como ciência.

Porém, sua importância ${ }^{74}$ é hoje acolhida e seus métodos e objetivos são estudados sistematicamente. Tanto nas relações econômicas quanto políticas (e nestas se insere os aspectos ambientais e, entre estes, do direito internacional ambiental) é de suma importância o conhecimento do direito internacional.

\footnotetext{
74 "O direito dos povos mais diversos contribui para esquematizar os grandes quadros históricos, através dos quais se projeta a Humanidade; partindo dos costumes de tribos primitivas, chamadas a testemunhar as origens do direito, o jurista fica maravilhado ao contemplar o direito dos povos mais avançados na civilização moderna. Maine na Inglaterra, Kohler na Alemanha são os prestigiosos representantes desta geração; foi com este espirito que se criou em 1831, no Collège de France, a primeira cátedra de legislação comparada. Hoje, a moda dessas generalizações passou. A contribuição que o direito comparado pode dar às investigações de ordem histórica e filosófica continua, entretanto, indiscutivel" (DAVID, 1998, p. 3).
} 
Quando o direito internacional é estudado dentro do método comparativo - direito comparado, torna-se muito mais fácil a sua compreensão, pois se passa a conhecer não somente a letra da lei, mas todo o contexto juridico e histórico no qual ela vem inserida.

O direito comparado é aplicado ao melhor conhecimento e maior compreensão dos institutos juridicos internacionais e preocupa-se não somente com as questões de direito público, mas também com as questões de direito privado.

A classificação dos diversos direitos existentes é imprescindível para um estudo comparativo mais aprofundado de cada sistema jurídico ${ }^{75}$. Tal classificação feita a partir do teor e das regras que compõem cada um dos direitos a ser analisado, considerando fundamentalmente os elementos estáveis formadores dessas regras.

Os diversos direitos são divididos e agrupados em famílias, o que restringe a um número bastante reduzido a quantidade de tipos de diretos a serem estudados, facilitando sua apresentação e compreensão. São elas:

Familia romano-germânica, que agrupa os países nos quais a ciência do direito se formou sobre a base do direito romano; familia da common law, que comporta o direito da Inglaterra e os direitos que se modelaram sobre o direito inglês; familia dos direitos socialistas, que tem seu berço na doutrina marxistaleninista, cuja fonte exclusiva de regras encontra-se na obra do legislador, que por sua vez exprime a vontade do partido comunista.

\footnotetext{
75 "Sistema juridico é o conjunto de regras e de principios juridicos, que se instituem e se adotam para regular todo o corpo de leis de um pais. Dentro dele, estabelecem-se os vários regimes juridicos $e$ se fundam as várias instituições legais, sejam de ordem interna, sejam de ordem externa" (DE PLÁCIDO E SILVA, v. 4, 1997, p. 242). É o conjunto coordenado das regras contidas, explicitamente ou implicitamente, no direito positivo, em um todo lógico (CRETELLA JÚNIOR, 1972) Para explicar sistemas jurídicos e institutos juridicos, o Professor CRETELLA JÚNIOR, utiliza-se de um comparativo singular, cuja simplicidade e presteza permite ao leitor um entendimento claro e inequívoco da questão. Compara o renomado mestre, o sistema jurídico aos alicerces de um edificio, ou às raízes de uma árvore, donde os institutos jurídicos de erguem como pilares, na primeira comparação, ou brotam como ramos, na segunda.
} 
A par dessas famílias, também classificadas como Bloco da Civilização Ocidental, apresentam-se outros direitos: os direitos muçulmano e hindu; os direitos do Extremo Oriente, ou seja, o direito da China e o direito do Japão; e, também, o direito da Africa e de Madagascar, estes apresentam-se, muito longe de uma adesão completa e sem reserva às idéias Ocidentais, ao contrário, em sua maior parte, continuam fiéis às suas concepções originárias do direito, em que este, ou é compreendido de modo diverso, ou não desempenha a mesma função que no Ocidente.

O sistema romano-germânico agrupa paises nos quais a ciência do direito se formou sobre a base do direito romano, tendo seu berço na Europa Continental (o direito de Portugal, França, Alemanha, Brasil e dos demais paises latino americanos, entre outros). Os direitos são agregados em duas grandes categorias, o direito público e o direito privado, essa distinção tem como base a idéia bastante clara que se faz das relações entre governantes e governados, é parte da lógica desses direitos que o interesse geral e os interesses particulares não podem ser pesados na mesma balança: a aplicação do direito público pressupõe que os administradores vejam os administrados como cidadãos e não como súditos, exigindo que os membros do governo e os administradores se submetam a uma disciplina e a um controle. Neste àmbito, as matérias, tanto do direito público, quanto do direito privado, encontram os mesmos ramos fundamentais. São eles: direito constitucional; direito administrativo; direito internacional público; direito criminal; direito processual; direito civil; direito comercial; direito do trabalho.

A concepção de regra de direito no sistema romano-germânico é base fundamental da codificação. Na elaboração da norma não se deve procurar a solução de todas as questões concretas que se apresentarão na prática, mas sim formular regras gerais, sistematizadas e acessíveis à descoberta e ao conhecimento, podendo ser facilmente aplicáveis às possíveis questões concretas. 
São fontes de seus direitos: a lei; o costume; a jurisprudência; a doutrina; e os princípios gerais. A lei é a principal fonte do direito. No vértice da hierarquia encontram-se as constituições ou leis constitucionais, sendo que todos os países pertencentes a esse sistema juridico possuem constituição escrita, cujas disposições são reconhecidas com relevante prestigio com relação às demais normas existentes, sendo que alguns paises conferem aos tratados e convenções internacionais, condição semelhante a das leis constitucionais, como, por exemplo, a França e a Holanda; abaixo, encontram-se os códigos ou leis ordinárias e, após, os regulamentos e decretos e, por fim, as circulares administrativas ${ }^{76}$.

O costume, como fonte secundária de direito, nos paises do sistema juridico romano-germânico, desempenha papel relevada importância. Além de constituir a base para construção da norma, direciona a forma pelo qual será aplicada.

Denotamos a presença do costume como fonte do direito, tanto em relação ao legislador, quanto ao juiz e à própria doutrina.

A jurisprudência nos paises do sistema juridico romano-germânico tem seu papel exclusivamente como elo de ligação entre o juiz e a lei. Constitui, portanto, basicamente uma interpretação da lei, sendo fonte excepcional do direito, utilizada somente em casos muito limitados, que conservam intocado o principio.

A doutrina assume papel fundamental como fonte do direito nesse sistema juridico, pois é ela que cria os diferentes instrumentos de trabalho dos juristas, agindo, não só sobre o legislador, provocando sua ação, como, também, na própria aplicação da lei, uma vez que representa a própria realidade das relações sociais reguladas.

\footnotetext{
${ }^{76}$ São dois os estilos de leis encontrados nesse sistema: há os que tendem a se exprimem de um modo tão compreensivel quanto possível para generalidade das pessoas (por exemplo, o direito alemão), e os que, inversamente, buscam uma tendência eminentemente técnica mais precisa, tomando um tanto mais inacessivel o direito para as pessoas desprezadas tecnicamente para interpretar as leis (por exemplo, o direito francês).
} 
Os principios gerais como fonte de direito encontram sua mais clara aplicação no sentido de justiça, prevalecendo à própria lei. Uma certa injustiça com a aplicação da lei num determinado caso concreto pode ser o preço necessário de uma ordem socialmente justa, porém, os juristas da família romano-germânica não estão prontos a aceitar uma solução que, no plano social, lhes pareça injusta. A eqüidade faz parte, como sempre fez, da essência do direito dos países pertencentes à família romano-germânica.

O sistema de direito da common law comporta o direito da Inglaterra e os direitos que se modelaram sobre o direito inglês, entre eles se destaca o direito dos Estados Unidos da América do Norte, tendo, também, influenciado praticamente todos os países que de alguma forma estiveram (ou estão) associados à Inglaterra, principalmente na organização administrativa e judiciária e no próprio direito processual.

A expressão técnica consagrada "common law" indica o direito não escrito de um país, baseado no costume, no uso e nas decisões das Cortes de Justiça, contrasta totalmente com o "Statute Law", que é o sistema estabelecido por um corpo legislativo reunido em códigos. Difere muito do direito romano-germânico. Entre os vários aspectos que marcam, essas diferenças pode-se citar a origem do próprio direito da common law que foi formada por juizes que tinham que resolver litígios particulares. Suas regras, ao contrário das existentes no direito romano-germânico, são concretas e visam dar solução a um processo e não formular uma norma geral de conduta para o futuro, sua preocupação é imediata e restringe-se a restabelecer a ordem perturbada e não, como no caso do direito romano-germânico, de lançar as bases da sociedade. A common law não se apresenta como um sistema que visa realizar a justiça; é mais um conglomerado de processos próprios para assegurar, em casos cada vez mais numerosos, a solução dos litígios (DAVID, 1998). 
Os direitos socialistas podem ser considerados subsidiários dum sistema original relativo ao sistema de direito romano-germânico, por esse motivo, o sistema jurídico socialista reserva, em suas raizes históricas e de formação da ciência jurídica, um grande número de características daquele direito, são as diferenças oriundas das doutrinas marxista-leninista que forçam à constituição de uma familia distinta de direitos. A fonte exclusiva de suas regras é, até a atualidade, a lei: expressão da vontade popular estritamente guiada pelo partido comunista ${ }^{77}$, estabelecendo, inicialmente, uma nova estrutura econômica, segundo a qual todos os bens de produção foram coletivizados, com a conseqüente ascensão do direito público em detrimento do direito privado.

Da familia dos direitos socialistas, convém distinguir, como constituindo grupos diversos, os direitos socialistas ou populares da Europa, e os direitos das repúblicas populares extra-europeus. Nos primeiros encontra-se maior incidência das características da família dos direitos romano-germânicos; nos segundos, mais especificamente na Ásia, denota-se a prevalência de princípios tradicionais da civilização extremo-oriental que governavam a sociedade antes a era do socialismo. Tal fato influi de modo bastante incisivo da questão dos direitos socialistas divergirem do regime político socialista.

O direito dos países do Extremo-Oriente, ainda que sob o regime político socialista, não pertencem à família dos direitos socialistas, mas formam um sistema juridico à parte.

O traço fundamental encontrado no direito muçulmano é, sem dúvida, a ligação intima que existe entre o direito e a religião.

\footnotetext{
${ }^{77}$ A lei resulta da vontade dos dirigentes, em função da própria organização política e econômica do poder: é conferida importância fundamental à lei, também porque se pretende fazer mudanças rápidas e de modo revolucionário, e é esse dinamismo necessário do direito socialista que vai contribuir, sobremaneira, à supremacia da lei como fonte de direito, em oposição com as demais fontes com processo mais lento de evolução, como a jurisprudência, o costume e a doutrina jurídica.
} 
O direito muçulmano não é um ramo autônomo da ciência, muito ao contrário, representa apenas uma das faces da religião islâmica. $\mathrm{O}$ char ou caminho $a$ seguir, constitui o chamado direito muçulmano. Indica ao muçulmano como se deve, segundo a religião, comportar-se, sem, entretanto, distinguir as obrigações que tem para com os semelhantes, daquelas que tem para com Deus. É, portanto, caracteristica fundamental do direito islâmico, a idéia das obrigações impostas ao homem e não aos direitos que ele poderia $\operatorname{ter}^{78}$.

As fontes do direito muçulmano são quatro. A primeira e mais importante é o Corão, o livro sagrado do islã, que constitui o fundamento de todo o direito muçulmano, como, também, da própria civilização muçulmana. É formado pelo conjunto de revelações de Alá ao último de seus profetas e mensageiros, Maomé.

A Suna, por sua vez, em complementação, relata o comportamento do Profeta, servindo como guia dos muçulmanos. A Suna revela os atos e propósitos de Maomé que estabeleceram, de modo sólido, as bases da fé muçulmana. O Idjmâ, terceira fonte do direito muçulmano, é constituído pelo acordo unânime dos doutores ou jurisconsultos que estabelecem, com força de verdade jurídica, soluções para os casos que não encontram resposta nem no Corão e nem na Suna. O Qiyâs, quarta fonte do direito muçulmano, é o raciocínio pela analogia. É, na verdade, um modo de interpretação e de aplicação do direito. Pretende ser não a criação de uma lei, mas uma imagem da realidade, nas palavras de RENĖ DAVID (1998, p. 415):

"...assemelha-se a um farol que deva guiar os crentes para o ideal
religioso."

\footnotetext{
78 "A concepção que dirige o Islã é a de uma sociedade teocrática, na qual o Estado não tem valor senão como servidor da religião revelada. Em lugar de proclamar simplesmente principios morais ou de dogma, aos quais as comunidades muçulmanas deveriam conformar os seus direitos, os juristas $e$ os teólogos muçulmanos elaboraram, sobre o fundamento da revelação divina, um direito completo, pormenorizado; o de uma sociedade ideal que um dia virá a estabelecer-se num mundo inteiramente submetido à religião do Islã... O Islã é, na sua essência, como o judaísmo, uma religião da Lei." (DAVID, 1998, p. 409).
} 
O direito hindu é sistema de direito tradicional, onde a autoridade é reconhecida e venerada por uma vasta comunidade, confundindo-se com o próprio hinduísmo. Corresponde muito mais a uma concepção do mundo e a forma de comportamento dos homens, do que a um dogma.

O hinduismo exerce papel fundamental nas relações relativas ao estudo pessoal, considerando o grande número de adeptos que a doutrina hindu possui e, ainda, considerando a sua influência quanto ao modo de vida de seus adeptos de acordo com sua condição social, chegando a elaborar preceitos, que ganham força de regra de direito.

Para a comunidade hindu, o homem representa uma abstração dividida em categorias sociais hierarquizadas, das quais cada uma impõe regras de comportamento diferentes, pois diferentes são os direitos, deveres e moral que lhe correspondem, determinadas através de obras chamadas sastras e estas são de diferentes espécies, uma para cada comportamento decorrente da motivação que lhe corresponde. As motivações são: a virtude, o interesse e o prazer; as espécies de sestras, correspondentes, são: o dharma, o artha e o kama ${ }^{79}$.

A tendência atual constatada na Índia é a de substituir o direito tradicional religioso, pelo conceito ocidental de um direito laico, autônomo em relação à religião. Por oposição ao direito hindu, um grande setor nas relações sociais da Índia é, hoje, governado por regras de alcance nacional.

Inspirado na concepção inglesa, o direito nacional da Índia e sua aplicação alcançam todas as tendências religiosas existentes no país, sejam elas muçulmanas, parsi, hindus ou cristãs.

\footnotetext{
${ }^{79}$ A ciência do dharma, virtude, ensina os homens como estes se devem conduzir para serem justos. $\dot{E}$ dirigida aos brâmanes; a ciência do artha, interesse, ensina a maneira de enriquecer e a arte de governar, é seguida pelos dirigentes e comerciantes; e a ciência do kama, prazer, destinada em primeiro plano às mulheres, que na doutrina hindu não têm destino próprio após a morte.
} 
Os paises do Extremo Oriente não consideram o direito uma condição de ordem ou um símbolo da justiça.

O direito é concebido, principalmente pelos chineses, como um instrumento do arbitrio de um fator de desordem. É conservada, tradicionalmente, a idéia de que o direito é bom para os bárbaros, sendo a conciliação a principal meta, com valor muito superior à justiça. ${ }^{80}$

Os japoneses e chineses, abstêm-se de recorrer aos tribunais e estes esforçam-se para levar os litigantes à conciliação, desenvolvendo assim técnicas bastante originais da aplicação do direito, ou, melhor dizendo, da dispensa da aplicação do direito. Assim, a mediação jurídica deve servir muito mais para dissolver os conflitos, do que o próprio direito para os resolver.

A concepção chinesa de ordem social é sustentada pela tradição e fundamenta-se, sem qualquer vínculo religioso, ao postulado da existência de uma ordem cósmica, onde há uma interação entre o céu, a terra e os homens. $O$ céu e a terra obedecem regras invariáveis, enquanto o homem é o senhor de seus atos; a ordem ou a desordem do mundo dependerá da maneira como os homens irão se conduzir. Essa harmonia, segundo a qual dependem o equilibrio do mundo e a felicidade dos homens deriva da harmonia dos homens com a natureza e da harmonia dos homens entre si.

O direito não é excluído, mas desempenha a função diminuta no ordenamento das relações sociais, onde a educação e a persuasão devem suplantar a autoridade e a coerção; as leis servem muito mais como modelos de conduta do que um meio para regular conflitos; o princípio da legalidade e a codificação são repudiados, as idéias tradicionais persistem e dominam a realidade da vida chinesa até os dias atuais.

\footnotetext{
80 "O bom cidadão não deve se preocupar com o direito; deve viver de uma maneira que exclua toda a reivindicação dos seus direitos e todo recurso à justiça dos tribunais. A preocupação primordial dos homens não deve ser dominada continuamente, fora de qualquer consideração jurídica, pela procura da harmonia e da paz" (DAVID, 1998, p. 24).
} 
Mesmo quanto às questões internacionais impera a conciliação, a resolução dos litígios mediante um acordo firmado pelas partes e, ao contrário de outros povos, os chineses não esperam que a solução resulte de uma sentença anunciada pela autoridade do árbitro.

O Japão, no curso de sua história, manteve relações com a China e, por esse motivo, sofreu influência chinesa, entretanto, conserva bastante originalidade quanto ao seu pensamento, em decorrência não só do caráter próprio e também tradicional do povo japonês, como, também, pelo seu isolamento absoluto durante dois séculos e meio; é hoje um país democrático liberal, tendo sofrido considerável influência ocidental, porém, convivem em perfeita harmonia as propostas ocidentais e a tradição do pensamento oriental.

Tem-se assim, a clara consciência de que o povo japonês não perdeu seu caráter conciliatório e a busca pela paz, muito mais que pelo direito ou pela justiça. A conciliação assume importância fundamental: ir aos tribunais é uma atitude condenável, deve-se, antes, buscar a solução amigável para o conflito, ainda que se tenha que recorrer a mediadores. Mas a arbitragem não é aceita pelo espírito antijurídico do povo japonês: a este parece desonesto prever a ocorrência de conflitos em um contrato, ao invés da cláusula de arbitragem procura-se inserir idéia de que qualquer dificuldade poderá ser resolvida através de acordo mútuo, fundado na boa vontade dos envolvidos.

O essencial para o povo japonês são as regras de comportamento estabelecidas pela tradição, para cada tipo de relação humana. Com exceção das relações entre grandes empresas despersonalizadas, não se recorrerá à justiça para fazer valer os direitos, antes, buscar-se-á a conciliação. Os tribunais exercem, nas relações entre particulares, muito mais a função de órgão conciliador do que de órgão julgador. 
Igualmente os direitos dos países do Extremo Oriente, os paises da África negra e em Madagascar conservam a idéia tradicional de direito, ou melhor, da não aplicação do direito pela busca da paz e da harmonia entre os demandantes, obtidas com a prática da conciliação. Também para esses a coesão social da comunidade é primordial, restando ao individualismo uma importância máxima. O ideal é a manutenção ou restauração da ordem, o respeito ao direito é quase inexistente.

O direito ocidental que foi estabelecido nos países da África e em Madagascar, não passa, na verdade, de aparência, pois a grande maioria da população desses países continua a viver de acordo com suas tradições, sem qualquer preocupação com o corpo de regras que lhes foi imposto de modo artificial. Seu direito é fundado basicamente nos costumes, muito antigos e que denotam enorme respeito aos antepassados, quase como um culto; os povos obedecem a uma ordem consuetudinária bastante primitiva, concentrando seu interesse em grupos perenes, como as tribos, as aldeias, as castas, as linhagens, desprezando elementos transitórios como a própria individualidade. Apesar da imposição da codificação e da instauração de regimes juridicos diversos durante o período de colonização desses países, certo é que após a independência dos mesmos, voltaram eles às antigas tradições com a aplicação quase exclusiva da ordem consuetudinária, muito embora seus dirigentes tenham conhecimento da imperativa modernização de seu sistema jurídico, para que possa ocorrer o desenvolvimento, principalmente econômico, desses países.

Com essa visão geral dos diferentes aspectos do direito no mundo, podese concluir que não existe ciência do direito que não seja universal, sendo o direito comparado um importante elemento desse universalismo, desempenhando, cada vez mais, um papel fundamental para o conhecimento e o progresso do direito (DAVID, 1998). Sendo certo, também, que a globalização favorece, de modo significativo, seu desenvolvimento, ante a franca e rápida expansão das relações comerciais internacionais $\mathrm{e}$, especificamente, nos aspectos relativos ao entendimento $\mathrm{e}$ à aplicação dos mecanismos jurídicos internacionais de proteção ambiental. 


\section{2. $O$ direito ambiental internacional}

\subsubsection{Aspectos gerais}

A internacionalização é uma das caracteristicas fundamentais do mundo contemporâneo. As relações internacionais se desenvolvem na medida da convivência dos povos. A globalização dá origem a um direito internacional que governa os povos em comunhão ${ }^{81}$.

É sabido que nenhum Estado pode bastar-se a si mesmo, ao contrário, as Nações necessitam de apoio reciproco, da associação e das relações mútuas com fins de utilidade ou de necessidade, sendo imprescindível instrumentos legais que regulem essas relações internacionais, sem olvidar as disposições diplomáticas que colhem subsidios de sua atuação nos recursos quase infinitos de um sistema fundado sobre a pluralidade dos Estados independentes.

Pode-se, assim, concluir que relações internacionais são tratativas protagonizadas pelos Estados, objetivando o equilibrio de convivência de seus povos, cujos relacionamentos são operados pelas regras do direito internacional (STRENGER, 2002).

\footnotetext{
${ }^{81}$ Toda sociedade descansa sobre elementos materiais e sobre fatores morais, sendo resultante de uma série de solidariedades suficientemente ativas para requerer a organização do poder, com a consciência da existência de um bem comum, capaz de suscitar a idéia do direito e o sentido da obrigação (Charles de Visscher, citado por STRENGER, 2002).
} 
Importante ressaltar que, nas relações internacionais, o direito do Estado impõe o exercício da soberania territorial e, em contrapartida, o dever de abster-se de todo ato coercitivo no território estrangeiro.

Assim, o território passa, de ordem política - independência e segurança, à ordem jurídica - primeiro passo na regulamentação da grande maioria dos problemas oriundos das relações internacionais.

As relações internacionais são resultantes de diversos fatores, dentre os quais se destacam: fator geográfico, fator demográfico, fatores econômicos, fatores técnicos e científicos, fator ideológico, cultural e espiritual, mídias (ou processos de informação e divulgação), e o fator jurídico (ou de direito internacional).

Nesse mister encontra-se a questão ambiental permeando todos os elementos desencadeadores das relações internacionais, dando origem a inúmeros tratados, convenções, recomendações, diretrizes, regras e normas visando à proteção do meio ambiente, e que, por sua amplitude e especificidade, pode ser abordada em apartado, com conteúdo próprio, no chamado direito ambiental internacional ${ }^{82}$.

\footnotetext{
${ }^{82}$ Por direito ambiental internacional, entendemos o conjunto de regras e princípios que criam obrigaçðes e direitos de natureza ambiental para os Estados, as organizaçðes intergovernamentais e os individuos (NASCIMENTO E SILVA, 1995).
} 


\subsubsection{Direito fluvial}

Especificamente no que diz respeito ao direito fluvial internacional, cumpre esclarecer que o domínio fluvial de um Estado compreende os rios propriamente ditos e os demais cursos d'água que cortam o território desse Estado, nos trechos situados dentro dos seus limites (ACCIOLY, 1986).

Os rios podem ser nacionais e internacionais. Os rios nacionais são os que correm inteiramente no território de um só Estado. Há, portanto, jurisdição plena deste, o que não impede a utilização por estrangeiros, através de concessões. A navegação ficará aberta a todos os Estados, mas a pesca e o aproveitamento agrícola e industrial são do exclusivo domínio do Estado a que pertence o rio.

Os rios internacionais podem se apresentar sob dois aspectos: sucessivos ou contíguos, também chamados fronteiriços. Os rios sucessivos são os que atravessam os territórios de dois ou mais Estados; cada Estado exercerá soberania plena na parte que lhe toca, mas a livre navegação é, geralmente, um princípio aceito na totalidade dos rios, respeitados os direitos dos Estados ribeirinhos, mas duas importantes restrições em relação à liberdade de navegação fluvial devem ser observadas: a navegação de cabotagem, efetivada apenas por navios mercantes nacionais e a exclusão da passagem de navios de guerra estrangeiros, salvo consentimento prévio. Ainda nos rios sucessivos, cada Estado poderá livremente pescar em sua parte, devendo, no entanto, evitar métodos predatórios que puderem prejudicar outros Estados ribeirinhos. 
Os rios internacionais são contíguos quando correm entre os territórios de dois Estados, nesse caso a soberania de cada Estado estende-se, no rio, até a linha divisória, podendo os respectivos Estados entrar em acordo para a efetivação da pesca em toda a extensão do rio (MATTOS, 1980).

Do mesmo modo, dependerá de acordo entre os Estados ribeirinhos interessados o aproveitamento agrícola e industrial dos rios internacionais, ante $o$ risco da poluição ou outros danos ambientais que podem resultar de sua utilização.

A esse respeito, algumas normas gerais foram adotadas desde 1933 , na $7^{\mathrm{a}}$ Conferência Internacional Americana:

a) os Estados têm direito exclusivo de aproveitamento, para fins agrícolas ou industriais, das águas dos rios internacionais que se encontram dentro de sua jurisdição, direito este subordinado à condição de não prejudicar direito igual do Estado vizinho, na margem ou na parte que lhe pertença;

b) em caso nenhum, quer se trate de rios sucessivos ou contíguos, as obras de aproveitamento poderão causar prejuizos à livre navegação desses rios; c) as obras a serem realizadas em rios internacionais deverão ser comunicadas previamente aos demais Estados ribeirinhos.

A utilização dos rios internacionais na Bacia do Amazonas e na Bacia do Prata encontra-se regulada por tratados entre o Brasil e os países ribeirinhos interessados, sendo que os relativos à navegação datam desde 1828 . 
Os principais tratados internacionais de recursos hídricos são a seguir elencados (Caderno Legislativo $n^{\circ} 3 / 98$ ):

a) Tratado da Bacia da Lagoa Mirim e Lagoa dos Patos, e Regularização do Curso do Rio Jaguarão: Decreto $\mathrm{n}^{\circ} 28.009$, de 1950; Decreto $\mathrm{n}^{\circ}$ 109, de 1977; Decreto ${ }^{\circ}$ 81.351, de 1978; Decreto $n^{\circ} 1.148$, de 1994.

b) Tratado da Bacia do Prata: Decreto-Lei $n^{\circ}$ 682, de 1969; Decreto $n^{\circ}$ 67.084, de 1970; Estatuto do Comitê Intergovernamental Coordenador dos Países da Bacia do Prata.

c) Tratado do Rio Paraná (Itaipu): Decreto $n^{\circ} 23$, de 1973; Decreto $\mathrm{n}^{\circ}$ 72.707, de 1973; Decreto $n^{\circ} 76$, de 1974; Decreto $n^{\circ} 75.242$, de 1975 .

d) Tratado de Cooperação Amazônica: Decreto n 69, de 1978; Decreto $\mathrm{n}^{\circ} 85.050$, de 1980 .

e) Tratado do Rio Uruguai e do seu afluente Rio Pepiri-Guaçu: Decreto $\mathrm{n}^{\circ} 82$, de 1982; Decreto ${ }^{\circ} 88.441$, de 1983.

f) Tratado da Bacia do Rio Quarai: Decreto ${ }^{\circ} 13$, de 1992; Decreto ${ }^{\circ}$ 657 , de 1992.

Convém ressaltar que a questão da poluição transfronteiriça ${ }^{83}$ de águas doces dos rios e lagos internacionais, fenômeno que, por sua natureza, não conhece fronteiras físicas e políticas entre Estados, constitui um dos fatores tópicos que precipitam a emergência do atual direito internacional do meio ambiente, a uma velocidade jamais verificada em outros ramos do direito (SOARES, 2001).

\footnotetext{
${ }^{83}$ Os textos de convenções mais modernos têm adotado a técnica de relacionar a noção de 'poluição' ao conceito de impacto. "Impacto transfronteiriço significa qualquer impacto, não exclusivamente de natureza global, dentro de uma área sob a jurisdição de uma Parte, causado por uma atividade controlada, cuja origem fisica se encontra situada totalmente ou em parte dentro da área sob a jurisdição de outra Parte" (artigo $1^{\circ}$, inciso VIII, da Convenção sobre Avaliação de Impacto Ambiental num Contexto Transfronteiriço, Finlândia, 1991).
} 


\subsubsection{Aspectos ambientais no direito fluvial internacional}

No que respeita aos danos transfronteiriços causados ao meio ambiente, os direitos e as práticas, nacionais e internacionais, não oferecem ainda regras operacionais claras sobre a imputação da responsabilidade jurídica de empresas de Estados, em conseqüência, muitos casos nos quais as companhias transnacionais se acharam implicadas, foram, até agora, solucionadas segundo princípios jurídicos diversos ${ }^{84}$.

O Conselho da Europa, em 1968, promulgou a Carta da Água, fixando princípios norteadores da ação político-legislativa dos estados europeus no que respeita à utilização da água. Posteriormente, em 1971, foi assinado o Convênio Interparlamentar Europeu sobre Poluição Hídrica, nele os países europeus e membros da Comunidade Européia acordaram que os encargos da poluição recairão sobre os seus autores, sejam eles pessoas física ou jurídicas, de direito público ou privado e, ainda, que todos os Estados aderentes deverão fixar um mínimo de qualidade obrigatória para os efluentes; devendo a unidade territorial de base ser constituida por bacias hidrográficas, reconhecendo que a luta contra a poluição das águas faz parte da gestão dos recursos hídricos (POMPEU, 1976). E, desde a promulgação da Carta da Água tantas normas, convenções, acordos e tratados foram formalizados, tendo cada vez mais a participação de maior número de países, numa crescente conscientização da problemática ambiental dos recursos hídricos.

\footnotetext{
${ }^{84}$ Os Estados, de conformidade com a Carta das Naçðes Unidas e com os princípios de Direito Internacional, têm a responsabilidade de assegurar que atividades sob sua jurisdição ou controle não causem danos ao meio ambiente de outros Estados ou de áreas além dos limites da jurisdição ou controle não causem danos ao meio ambiente de outros Estados ou de áreas além dos limites da jurisdição nacional. Principio 2 da Declaração do Rio (1992).
} 
Importante documento internacional relativo à proteção das águas, que merece especial referência, é a Convenção sobre a Proteção e Utilização de Cursos d'Água Transfronteiriços ${ }^{85}$ e Lagos Internacionais, firmada em Helsinque em 1992 , cujo conteúdo se acha sistematizado (e reunido às demais normas internacionais posteriormente criadas para proteção dos cursos d'água transfronteiriços), na Convenção das Nações Unidas sobre o Direito das Utilizações dos Cursos d'Água Internacionais para Fins Distintos da Navegação, proposta pela Comissão de Direito Internacional das Nações Unidas e adotada pela Assembléia Geral das Nações Unidas, em 1997, em Nova Iorque.

São princípios contidos na referida convenção, entre outros:

a) principio da precaução, no qual é previsto que uma ação destinada a evitar o impacto transfronteiriço potencial da liberação de substâncias perigosas não deverá ser adiada, sob a alegação de que a pesquisa científica não tenha, ainda, inteiramente provado uma ligação causal entre, de um lado tais substâncias e, do outro, o efeito transfronteiriço potencial;

b) princípio do poluidor-pagador, no qual é previsto que os custos das medidas de prevenção da poluição, de controle e de redução, serão arcados pelo poluidor;

c) princípio da sustentabilidade, que prevê que os recursos da água deverão ser gerenciados de tal maneira, que as necessidades das gerações presentes sejam satisfeitas, sem comprometer a possibilidade das gerações futuras satisfazerem às suas próprias.

\footnotetext{
${ }^{85}$ Segundo o artigo $1^{\circ}$ da Convenção, "águas transfronteiriças siginifica quaisquer águas de superficie ou lençóis freáticos que demarcam. cruzam ou se localizam nas fronteiras entre dois ou mais Estados (...)." E a importância na definição de águas trnsfronteiriças reside no fato de ter-se considerado como campo de aplicação da Convenção o elemento água compartida em seu sentido mais amplo, seja como componente de um rio internacional (sucessivo, contíguo ou internacionalizado), como lago ou lagoa (de águas doces ou salgadas), ou como lençóis freáticos.
} 
Nesse sentido, a Convenção das Nações Unidas sobre os Direitos do Mar, em Montego Bay, 1982, determina, em sintese, que os Estados têm a obrigação de proteger o meio marinho, tendo o direito de soberania para aproveitar os seus recursos naturais de acordo com a sua política em matéria de meio ambiente e de conformidade com o seu dever de proteger e preservar o meio marinho. $\mathrm{O}$ mar territorial brasileiro ${ }^{86}$ é regulado pela lei $n^{\circ} 8.617 / 93$ e, sendo evidente a interação, do ponto de vista ambiental, entre o litoral e o mar, o Brasil dispõe de um Plano Nacional de Gerenciamento Costeiro, como parte integrante de sua Política Nacional para os Recursos do Mar e da Política Nacional do Meio Ambiente (OLIVEIRA, 1999).

As relações internacionais relativas à utilização dos cursos d'água transfronteiriços estão sedimentadas no dever de cooperação, sob bases de igualdade e reciprocidade, com a finalidade de serem desenvolvidas pelos Estados, no âmbito interno, políticas, programas e estratégias uniformes e harmônicas, com adoção de medidas de ordem legal, administrativa, econômica, financeira e técnica. Essas medidas têm, como principais objetivos:

a) prevenir, controlar e reduzir a poluição das águas que causem ou possam causar impactos transfronteiriços;

\footnotetext{
${ }^{86}$ Pertencem à União os lagos, rios e quaisquer correntes de água em terrenos de seus domínios, ou que banhem mais de um Estado, sirvam de limites com outros paises ou se estendam a território estrangeiro ou dele provenham, bem como os terrenos marginais e as praias fluviais. $O$ Brasil ratificou a Convenção sobre o Direito do Mar, introduzindo modificaçðes na ordem jurídica interna pela Lei $\mathbf{n}$. 8.617/93, nela a soberania do Estado costeiro estende-se, além do território e das águas interiores, ao mar territorial e à Zona Econômica Exclusiva, definida como uma faixa adjacente ao mar territorial que se estende das 12 milhas até as 200 milhas marítimas, na qual o Estado exerce direitos de soberania para fins de exploração e aproveitamento, conservação e gestão dos recursos naturais, existentes na água, no leito e no subsolo, produção de energia a partir da água ou dos ventos, porém, não o fazendo, deverão tornar o excedente acessivel a outros Estados, mediante acordo (QUADROS DA SILVA, 1998).
} 
b) assegurar que as águas transfronteiriças sejam utilizadas de forma saudável e racional para conservação dos recursos da água e proteção do meio ambiente;

c) assegurar que as águas transfronteiriças sejam utilizadas de maneira racional e ecologicamente eqüitativa, no caso de atividades que causem ou possam, provavelmente, causar impacto transfronteiriço;

d) assegurar a conservação e, quando necessário, a restauração de ecossistemas, levando-se em consideração seu caráter transfronteiriço.

Nas propostas de cooperação entre Estados com cursos d'água transfronteiriços, devem, também, ser criados órgãos conjuntos para estabelecimento de uma regulamentação mínima, visando à manutenção da sanidade das águas doces compartidas entre Estados. Os órgãos conjuntos são encarregados de:

a) coligir, compilar e avaliar dados para identificação das fontes de poluição que causem impacto transfronteiriço;

b) elaborar programas de monitoramento da qualidade e quantidade da água;

c) elaborar inventários e realizar a troca de informações sobre as fontes de poluição das águas, determinando limites de emissões para águas servidas;

d) elaborar objetivos conjuntos de qualidade de água, propondo medidas relevantes para manter e melhorar a qualidade da água; avaliar a efetividade dos programas de controle da qualidade das águas;

e) desenvolver programas para redução das cargas de poluição das fontes municipais, industriais e difusas, especialmente da agricultura;

f) estabelecer procedimentos de advertência e de alarme ${ }^{87}$;

\footnotetext{
${ }^{87}$ Trata-se do dever de informação sobre qualquer situação crítica que possa causar impacto transfronteiriço, instituindo e operando, quando for o caso, comunicaçðes conjuntas e sistemas de alarmes com o fim de obter e transmitir informaçðes. Sendo que, se uma situação crítica se apresentar, os Estados ribeirinhos deverão prestar-se assistência mútua, cujos procedimentos já devem encontrarse previamente estabelecidos de comum acordo entre as partes.
} 
g) promover o intercâmbio de informações ${ }^{88}$ sobre usos existentes e planejados da água, sobre as instalações que possam causar impacto transfronteiriço e sobre a melhor tecnologia disponível;

h) encorajar a coorperação nos programas de pesquisa científica, participando na implementação de avaliações de impacto ambiental relacionados com águas transfronteiriças.

A respeito da importância das informações ao público, dispõe o princípio 10 da Declaração do Rio, em 1992:

"A melhor maneira de tratar as questões ambientais é assegurar a participação, no nivel apropriado, de todos os cidadãos interessados. No nivel nacional, cada individuo deve ter acesso adequado a informações relativas ao meio ambiente de que disponham as autoridades puiblicas, inclusive informações sobre materiais e atividades perigosas em suas comunidade, bem como a oportunidade de participar em processos de tomada de decisões. Os Estados devem facilitar e estimular a conscientização e a participação pública, colocando a informação à disposição de todos. Deve ser propiciado acesso efetivo a mecanismos judiciais e administrativos, inclusive no que diz respeito à compensação e reparação de danos".

Um rio de interesse de mais de um Estado forma parte de um complexo hidrográfico e humano mais amplo que uma simples via de acesso aquática existente no interior dos Estados.

\footnotetext{
${ }^{88}$ As informaç̃̃es sobre as condições das águas transfronteiriças, as medidas tomadas ou planejadas para evitar, controlar ou reduzir o impacto transfronteiriço, bem como a efetividade de tais medidas, devem ser franqueadas ao público, especialmente os objetivos da qualidade da água, as permissões concedidas e as condiçð̃es requeridas para sua expedição, os resultados das águas e efluentes realizados com a finalidade de controlar e avaliar e, também, os resultados de constatações de compatibilidade entre os objetivos da qualidade da água e as condiçð̃es das permissð̃es.
} 
Dessa forma, a emergência do conceito água, como valor supremo a ser protegido, sobrepõe-se a outros fins na utilização de rios e lagos internacionais, sobretudo ante sua nova condição de bem escasso, em virtude da perda de suas qualidades dirigidas à satisfação de necessidades imediatas e elementares dos componentes da biosfera, entre os quais se encontra o homem, com seu consumo direto, seu uso na preparação de alimentos, higiene pessoal e, também, à sanidade primária de seu habitat, conferindo à água um valor maior, uma posição privilegiada no que respeita à regulamentação internacional dos chamados recursos naturais compartidos (SOARES, 2001).

\subsection{As convenções e os tratados internacionais ambientais}

De acordo com FREITAS (2001), o Direito Internacional do Meio Ambiente teve sua primeira manifestação em 1902, em Paris, com a convenção para proteger aves úteis à agricultura. A seguir outros eventos relevantes no âmbito ambiental aconteceram: Congresso Internacional para Proteção das Paisagens, Paris, 1909; Conferência de Berna, em 1913, para proteção da natureza; convenção visando à conservação da flora e da fauna da África, Londres, 1933; convenção destinada à proteção da fauna, flora e belezas panorâmicas da América, Washington, 1940; Conferência Internacional para Proteção da Natureza, Basiléia, 1946; Conferência de Fontainebleau, 1949; Colóquio Internacional do Centro Nacional de Pesquisa Científica sobre a Ecologia, Paris, 1950; convenção destinada a impedir a poluição do mar, Londres, 1954; em 1960, em Paris, o primeiro de uma série de encontros destinados a regulamentar o uso da energia nuclear; Simpósio sobre as Poluições Industriais, Londres, 1964 (MUKAI, 2002). 
O grande marco no direito ambiental internacional foi a Conferência das Nações Unidas sobre o Ambiente Humano, realizada em 1972 em Estocolmo. Contendo 26 principios e um plano de ação composto de 109 resoluções, a Declaração de Estocolmo lança as bases de uma legislação internacional no campo do meio ambiente, fazendo as nações compreenderem, desde então, que nenhum esforço, isoladamente, é capaz de solucionar os problemas ambientais do Planeta ${ }^{89}$.

Ao lado das regras de aplicação às relações bilaterais, da Conferência de Estocolmo emergiram princípios jurídicos de natureza internacional relativos à proteção ambiental $^{90}$, dentre os quais se destacam ${ }^{91}$ :

a) o dever de todos os Estados de proteger o ambiente, extrapolando a limitação de proteção ao próprio território e estendendo-a ao meio ambiente em geral;

b) a obrigatoriedade do intercâmbio de informações e da consulta prévia, entre os governos que se propõem a elaborar trabalhos com efeitos ambientais e aqueles que repartem os recursos naturais que possam vir a ser afetados por tais efeitos;

c) o princípio da precaução, que corresponde ao dever do Estado de prevenir atos nocivos ao meio ambiente, considerado o mais importante princípio, ao lado do qual se destacam, ainda,

d) o princípio do aproveitamento equitativo, ótimo e razoável dos recursos naturais;

\footnotetext{
${ }^{89}$ Nenhum país ou continente no mundo é capaz de resolver sozinho o problema da camada de ozônio, da alteração do clima global ou do empobrecimento dos nossos recursos genéticos. É indispensável a cooperação de todos. Sendo que esse todo compreende, também e sobretudo, as populaçð̄es que vivem nos países não industrializados, as quais são pobres e querem desenvolver-se. Assim, o problema do desenvolvimento nas suas relações com o ambiente deve ser considerado em toda a sua amplitude e de modo definitivo (KISS, 1996).

${ }^{90}$ Princípios estes que constituem regras costumeiras, que podem ser utilizadas em face de todos os Estados, formulados inicialmente em instrumentos não obrigatórios, como declaraçőes, e, posteriormente, repetidos em documentos obrigatórios, como tratados internacionais.

91 $\mathrm{O}$ homem tem direito fundamental à liberdade, à igualdade e às condiçðes de vida adequada em um ambiente que permita uma vida digna e de bem-estar; com a grave responsabilidade de proteger e melhorar o ambiente para as geraçðes presentes e futuras (VIANA, 2002).
} 
e) o principio do poluidor pagador; $\mathrm{e}$

f) o principio da igualdade, segundo o qual o Estado não pode fazer discriminação na sua legislação quanto ao local em que os efeitos ambientais serão suportados, ou seja, não pode criar normas legais menos rígidas para os casos em que os efeitos ambientais da ação ocorrerem em outro Estado.

Como conseqüência da Conferência de Estocolmo, surge uma consciência internacional de proteção ao meio ambiente e inúmeros documentos $\mathrm{e}$ tratados são assinados com esse fim. Outras conferências, programas e encontros se seguiram, entre eles: a Conferência de Helsinque, em 1975, e de Munique, em 1984, nas quais os paises do Leste Europeu demonstraram uma vontade comum de proteger o meio ambiente, independentemente de suas divergências ideológicas; o Programa de Montevidéu de desenvolvimento e exame periódico de Direito Ambiental, realizada em 1981 e tornada oficial pela Organização das Nações Unidas em 1982, onde surgiram importantes recomendações ${ }^{92}$ no campo internacional; a Conferência Interparlamentar sobre o Meio Ambiente, em 1984; a Declaração de Haia e de Paris, de 1989, na qual o grupo dos sete países mais industrializados consagrou que os países mais poluentes aceitem tomar coletivamente em consideração os prejuizos ambientais de seu desenvolvimento econômico; a Comissão Mundial sobre Meio Ambiente e Desenvolvimento - CMAD, em 1987, conhecida por Comissão Brundtland, recomendou a criação de uma carta ou declaração universal sobre a proteção ambiental e o desenvolvimento sustentável; a Reunião de Limoges, de 1990, que reuniu juristas ambientais de todo mundo para tratar das regras de direito ambiental internacional, dando origem às Recomendações para aplicação do direito internacional do meio ambiente.

\footnotetext{
92 Contaminação marinha; proteção da camada de ozônio da estratosfera; transporte, manipulação e eliminação de rejeitos tóxicos e perigosos; cooperação internacional em casos de emergência em matéria ambiental; ordenação das zonas costeiras; conservação do solo; contaminação transfronteiriça do ar; contaminação internacional de produtos químicos potencialmente nocivos; mecanismos juridicos e administrativos para a prevenção e a reparação dos danos ambientais.
} 
Os documentos mais importantes, porém, surgiram em decorrência da Conferência das Nações Unidas sobre o Meio Ambiente e o Desenvolvimento, conhecida como ECO-92, realizada no Rio de Janeiro, em 1992. Resultaram dessa conferência a Declaração do Rio, também chamada Carta da Terra, e a Agenda 21, com o objetivo de criar regras internacionais, de âmbito mundial, que assegurem a proteção do meio ambiente, considerando a necessidade de garantir aos países menos ricos o direito ao desenvolvimento e, ao mesmo tempo, evitar a degradação ambiental.

Em 1995, realizou-se o Seminário Internacional sobre a Carta da Terra, realizado em Haia, na Holanda, definiu as necessidades, os elementos principais e a forma de elaboração da Carta da Terra, como fruto da ECO 92. E, em 1996, inicia-se, com vários grupos o processo de consulta, como parte da preparação para o Rio +5 , que ocorreu no Rio de Janeiro, em 1997, cinco anos depois do Eco 92. Durante o Rio+5, em 1997, foi constituída uma Comissão da Carta da Terra. Naquela ocasião chegou-se ao texto da primeira minuta de referência, que balizou as discussões em todo o mundo, aprovada em Paris, em 14 de março de 2000.

Baseada em princípios e valores fundamentais no que se refere ao desenvolvimento sustentável, a Carta da Terra é tida como um código ético planetário, equivale à Declaração Universal dos Direitos Humanos, no que concerne a sustentabilidade, à eqüidade e à justiça. Entre os valores que se afirmam encontramos:

a) o respeito à Terra e à sua existência, a proteção e restauração da diversidade, da integridade e da beleza do ecossistema da Terra;

b) a produção, consumo e reprodução sustentáveis, o respeito aos direitos humanos, incluindo o direito a uma meio ambiente propicio à dignidade e ao bem estar dos humanos;

c) a erradicação da pobreza, a Paz e a solução não violenta dos conflitos, a igualdade de gênero; 
d) a distribuição eqüitativa dos recursos da Terra, a participação democrática nos processos de decisão, a responsabilidade e a transparència nos processos administrativos;

e) a promoção e aplicação dos conhecimentos e tecnologias que facilitem o cuidado com a Terra, a educação universal para uma vida sustentada, o sentido da responsabilidade compartilhada, pelo bemestar da comunidade da Terra e das gerações futuras.

A Carta da Terra é a declaração da responsabilidade da raça humana, uns aos outros, com a grande comunidade da vida e com as gerações futuras. Segundo a qual existe uma só família humana e uma só comunidade terrestre com um destino comum. A humanidade é parte de um vasto universo evolutivo. ${ }^{93}$

Ainda, a partir das recomendações da Conferência Rio-92, contidas na Agenda 21, foi criado pela ONU - Organização das Nações Unidas, o Dia Internacional da Água - 22 de março. Foi, a seguir, proclamada a Declaração Universal dos Direitos da Água, tendo como objetivo atingir todos os indivíduos, todos os povos e todas as nações para que todos os homens se esforcem através da educação e do ensino, em desenvolver o respeito aos direitos e obrigações nela anunciados e assumam, com medidas progressivas de ordem nacional e internacional, o seu reconhecimento e a sua aplicação efetiva ${ }^{94}$.

\footnotetext{
${ }^{93}$ A Terra está viva com uma comunidade de vida única. O bem estar dos povos e da biosfera depende da preservação do ar limpo, das águas puras, dos solos férteis, uma rica variedade de plantas, animais e ecossistemas. O meio ambiente global com seus recursos finitos é uma preocupação comum primordial para toda a humanidade. A proteção da vitalidade, diversidade e beleza da Terra são um dever sagrado.

${ }^{24}$ A água faz parte do patrimônio do Planeta; cada um é responsável aos olhos de todos; é condição essencial de todo ser vegetal, animal ou humano; o direito à água fundamental para o ser humano; a água deve ser manipulada com racionalidade, precaução e parcimônia, pois o equilibrio e o futuro do Planeta dependem da preservação da água e de seus ciclos, assim sua proteção constitui uma necessidade vital e, da mesma forma, uma obrigação moral do homem para com as geraçðes presentes e futuras; ela tem um valor econômico e não deve ser desperdiçada, nem poluída e nem envenenada; sua utilizaçăo deve ser feita com consciência e discernimento para que não se chegue a uma situaçăo de esgotamento ou de deterioração da qualidade das reservas atualmente disponiveis; o respeito à lei ambiental é uma obrigação jurídica para todo o homem ou grupo social que a utiliza, sua gestão impz̃e um equilibrio entre os imperativos de sua proteção e as necessidades de ordem econômica, sanitária e social e seu planejamento deve levar em conta a solidariedade e o consenso em razão de sua distribuição desigual sobre a terra.
} 
A Agenda 21 é um conjunto amplo e diversificado de diretrizes que trata de questões atinentes aos recursos naturais e à qualidade ambiental, procurando dar sustentabilidade ao desenvolvimento econômico (SIRVINSKAS, 2002).

Dentre as diretrizes da Agenda 21 destacam-se:

a) estímulo à cooperação internacional e nas relações internas;

b) ênfase na gestão ambiental descentralizada e participativa;

c) valorização e incremento do poder local;

d) multiplicação de parcerias para o desenvolvimento sustentável;

e) mudança nos padrões de consumo e nos processos produtivos.

De acordo com os principios contidos na Declaração do Rio e na Agenda 21 , pode-se concluir que existe hoje uma consciência de que o meio ambiente é um valor global e que, na sua essência, extrapola as fronteiras políticas e jurídicas dos Estados, devendo, estes, desenvolverem uma legislação nacional relativa à responsabilidade e indenização das vítimas de poluição e outros danos ambientais, bem como de cooperar de forma expedita e determinada para o desenvolvimento de normas de direito internacional ambiental relativas à responsabilidade e indenização por efeitos adversos de danos ambientais causados, em áreas fora de sua jurisdição, por atividades dentro de sua jurisdição ou sob seu controle (VIANA, 2002).

Ao tratar dos meios de implementação, o documento ressalta a promoção da consciência ambiental e o fortalecimento das instituições para o desenvolvimento sustentável, evidenciando instrumentos e mecanismos legais internacionais; apela fortemente para a consciência dos Poderes Públicos e da sociedade para criarem ou desenvolverem e aperfeiçoarem o ordenamento jurídico necessário à gestão ambiental para o desenvolvimento sustentável; e, como objetivos sociais de transcendental importância, surgem a erradicação da pobreza, a proteção da saúde humana e a promoção de assentamentos humanos sustentáveis (MILARÉ, 1997). 
A partir de então tantas outras conferências e convenções ambientais têm sido realizadas, sem, porém, conseguir atingir, até o presente momento, as propostas lançadas na Agenda 21. Em 1998, ocorre em Cuiabá, Mato Grosso, no Brasil, a primeira Conferência Regional, envolvendo os países da América Latina e Caribe e da América do Norte, essa conferência abriu o processo das sistematizações continentais $^{95}$.

A preocupação do MERCOSUL com as questões ambientais é regida pelo Tratado de Assunção, cujos objetivos principais são o aproveitamento dos recursos disponíveis e a preservação do meio ambiente. $E$, entre os Estados-membros são firmadas as seguintes resoluções, entre outras, dispondo sobre questões ambientais: a) Resolução $n^{\circ} 3 / 92$ estabelece critérios gerais para embalagens e equipamentos alimentares em contato com alimentos; b) Resolução $n^{\circ} 22 / 92$, cria a Reunião Especializada de Meio Ambiente; c) Resolução n ${ }^{\circ}$ 62/92, sobre resíduos de praguecidas nos produtos agrícolas; d) Resolução $n^{\circ} 53 / 93$, estabelece o código de conduta para a introdução e liberação ao meio ambiente de agentes de controle biológico; e) Resolução $\mathrm{n}^{\circ} 57 / 93$, aprova diretrizes de políticas energéticas no Mercosul; f) Resolução $n^{\circ}$ 67/93, estabelece normas de fiscalização sanitária animal; g) Resolução $n^{\circ}$ 84/94, estabelece limites máximos de emissão de gases contaminantes; h) Resolução $n^{\circ} 85 / 94$, estabelece limites máximos de emissão de ruidos veiculares (GARCIA JÚNIOR, 1997).

\footnotetext{
95 La loro stessa esistenza si connette ad uno spazio territoriale omogeneo chiamato regione internazionale e determinato da fattori geografici, geo-politici o, più ampiamente, geo-culturali. In tal senso le organizzazioni internazionali regionali si distinguono da quelle universali, parti di um regime diversificato ma unico, nel quale, infatti, esse al pari delle seconde possono assumere uma vocazione generale oppure specializzata. Per tali ragioni esse hanno trovato um sucsessivo espresso e sai purê parziale riconoscimento nella Carta dell'ONU, nella tríplice veste di organismi politici ed economici decentrati o almeno collegatti. La nozione di organizzazione regionale, però, si è sviluppata in modo peculiare sai in Europa che fuori d'Europa dando vita a modelli a autonomi e cioè caratterizzati da um sempre maggior grado di evoluzione e d'indipendenza rispetto all'ONU. Il regime attuale è quello del pluralismo regionale e del regionalismo autonomo (PANEBIANCO, 2002).
} 
A poluição e os danos não conhecem fronteiras, assim, uma luta para preveni-los ou remediar suas conseqüências só é possível em âmbito global e por meio de um sistema internacional de cooperação entre os Estados, de forma coordenada e harmonizada com suas políticas e leis internas (SOARES, 2001).

No entanto, as relações internacionais de um pais regem-se dialeticamente por fatores complementares que conjugam o interesse nacional e o interesse universal - o chamado "pensar a humanidade" que, segundo Celso Lafer ${ }^{96}$ é verificado, de um lado por valores e princípios de aceitação geral na comunidade das nações, e, de outro, por aspirações e interesses particulares das sociedades à luz da sua singularidade cultural, histórica, econômica e política. Assim, de um lado, tem-se a convergência de processos nacionais em direção a práticas e ideais que se universalizam - como, hoje, expresso no fortalecimento da democracia, dos direitos humanos e do mercado. $E$, de outro, as divergências ou forças de desagregação manifestadas no recrudescimento dos nacionalismos, das paixões étnicas e religiosas. Considerando que, em geral, os interesses nacionais são definidos pelas elites dos paises e que o poder relativo desses no cenário internacional é tido tradicionalmente como função da sua força militar ou econômica, o que dificulta, sobremaneira, a consecução dos interesses universais (BORN, 1998).

O palco do regime da Convenção Quadro de Mudança de Clima, em Kyoto, demonstra claramente a existência de vários pólos, distintas relações e ordens, mutáveis, no cenário mundial, e não uma única ordem internacional.

A complexidade das ações humanas e suas relações sociais, paralelamente às dinâmicas ecológicas essenciais, leva a conclusão de que não se pode falar em desenvolvimento auto-sustentado de um país, se no planeta como um todo não houver condições para a sustentabilidade global.

\footnotetext{
${ }^{96}$ Conforme estudos de BORN, 1998.
} 
Nesse passo, é consenso que a sustentabilidade ${ }^{97}$ global somente poderá se tornar realidade a partir da ampliação e efetivação das iniciativas de cooperação internacional $^{98}$, cujos principais atores são as redes formadas por Organizações Não Governamentais.

E, se é difícil elaborar normas internacionais sobre poluição, não é menos dificil aplicá-las, ou melhor, fazer com que sejam cumpridas.

A questão da efetividade das normas ambientais internacionais é abordada, em separado, em capítulo próprio, porém adiante-se à idéia da necessária consciência ambiental universal, com as sempre atuais palavras de Samuel Murgel Branco (1972), ao dizer que na elaboração de leis ambientais deve-se, antes, buscar o sentido moral e educativo, pois os povos devem ser orientados em suas ações, o que poderá, de melhor forma, se dar pela criação de uma consciência pública da importância vital da conservação do ambiente.

\subsection{O papel das organizações não governamentais e das organizações intergovernamentais na questão ambiental}

Popularizadas com a denominação da sigla ONG's, as Organizações Não Governamentais exercem papel relevante nas questões ambientais.

\footnotetext{
${ }^{97}$ Sustentabilidade é também entendida como gestão e disponibilidade dos recursos do planeta, para as geraçðes futuras, dando responsabilidade à espécie humana pela conservação dos recursos naturais, diante das outras espécies (DORADO, 1998).

${ }_{98}$ Coorperação significa renunciar parcelas de soberania, de auto-poder; significa reconhecer e estabelecer limites do próprio poder e das próprias capacidades, estabelecendo a interdependência nas manifestaçס̃es do processo de globalização (BORN, 1998).
} 
As Organizações Não Governamentais são fenômeno que podem ser visualizados desde o final do século XIX, simultaneamente ao surgimento das primeiras organizações intergovernamentais modernas. A década de 1960 é marcada por uma proliferação de organizações não governamentais em âmbito nacional, tendo por objetivo a defesa do meio ambiente; essas associações logo encontrariam suas correlatas em outros paises para a elas se ligarem ou com elas estabelecerem programas de ação conjuntos (SOARES, 2001).

Atualmente, as Organizações Não Governamentais são numerosas e podem ser definidas como: qualquer organização que não seja estabelecida por uma entidade governamental, nem por um acordo intergovernamental ${ }^{99}$; ou, em outras palavras: entidades criadas por atos de particulares, com ou sem a interveniência de órgãos oficiais, e constituídas segundo a lei de um Estado determinado que, em geral, as sedia. Suas finalidades, geralmente, prendem-se a interesses profissionais privados e locais, mas, em especial, em matéria científica e de meio ambiente, por força dos interesses globais de pesquisa, difusão de conhecimentos e necessidades de ganharem mais poderes de convencimento, ramificaram-se pelo mundo todo, constituindo filiais ou entidades associadas em outros paises diferentes de suas sedes (SOARES, 2001).

As Organizações Não Governanmentais são um fenômeno recente da prática internacional. Como o nome indica, seus integrantes são particulares e não Estados. Nesse sentido, elas se aproximam das características das empresas transnacionais, mas sem fins lucrativos. Portanto, as ONG's internacionais podem ser definidas como sendo as organizações privadas, movidas pela solidariedade transnacional, sem fins lucrativos, estando seu surgimento vinculado ao grau de maturidade e participação da sociedade, motivo pelo qual sua presença é mais acentuada na América do Norte e na Europa Ocidental (VIANNA e MOREIRA, 2004).

\footnotetext{
${ }^{99}$ Definição constante das Resoluçð̃es do Conselho Econômico e Social (ECOSOC), da Organização das Naçס̃es Unidas.
} 
A ONU - Organização das Nações Unidas reconhece, unicamente em relação às reuniões do seu Conselho Econômico e Social - ECOSOC, os seguintes tipos de Organizações Não Governamentais:

a) organizações com status consultivo geral, cujos direitos são de participar de qualquer reunião do Ecosoc, podendo apresentar oralmente, uma única vez, seus argumentos, mas sem direito a voto. Suas atribuições são: dar uma contribuição substantiva e efetiva para a consecução dos objetivos da ONU, estarem envolvidas na vida econômica e social das áreas dos povos que representam, ser constituida por um número considerável de membros, os quais devem ser representativos dos mais amplos segmentos da sociedade, em grande número de países e em diferentes regiões do mundo;

b) organizações com status consultivo especial, são aquelas com competência especial, preocupadas com alguns campos de atividades específicas cobertas pelo Ecosoc. Seus direitos são exclusivamente de participar das reuniões para as quais se acham credenciadas em função de sua especialidade, mas sem direito a voz ou a voto;

c) organizações incluidas na lista, são aquelas que não se enquadram nas categorias anteriores, mas que o Ecosoc ou o Secretário-Geral da ONU considerem poder dar contribuições ocasionais e úteis às atividades desse Conselho. Seus direitos são restritos e somente participam, sem direito a voz ou voto, das reuniões para as quais foram convocadas por uma especialidade extremamente particular;

d) organizações com status consultivo, são grandes organizações cujos objetivos são promover as finalidades, metas e objetivos da ONU e o fomento da compreensão de seu trabalho. Não têm, entretanto, direitos descritos nas normas do Ecosoc, não tendo direito à presença, participação, voz ou voto nas reuniões desse Conselho. 
Merecem especial destaque, por sua elevada dedicação ao meio ambiente, as seguintes Organizações Não Governamentais: IUCN - União Internacional para a Conservação da Natureza e seus Recursos; WWF - World Wildlife Fund, fundação de direito suíço, cuja principal atividade é o financiamento de operações, em qualquer parte do mundo, visando a conservação do meio ambiente; Greenpeace, que, entre outras expressivas ONG's, tem papel relevante nas questões ambientais, especialmente por suas operações de oposição aberta e agressiva contra ações atentatórias ao meio ambiente, perpetradas seja por parte dos governos, seja das grandes empresas nacionais ou multinacionais.

É inegável a atuação das Organizações Não Governamentais nos dias de hoje, em especial nas relações internacionais, enquanto atores da mais alta relevância, sobretudo pela atividade de conscientizar, convocar e mobilizar a opinião pública contra atos atentatórios ao meio ambiente (SOARES, 2001).

A importância das Organizações Não Governamentais, ao lado de outros setores relevantes das sociedades, como atores na determinação das políticas e das normas relativas à proteção do meio ambiente, é reconhecida na Agenda 21, documento resultante da Eco-92, que traça as ações político-normativas a serem adotadas pelos Estados.

Na Agenda 21 há importantes princípios sobre as necessidades de se reconhecer o valor de determinados setores das sociedades, os quais se acham inscritos nos capitulos sobre o Fortalecimento do papel dos Grandes Grupos Sociais e o Fortalecimento do Papel das Organizações Não Governamentais: Parceiros para o Desenvolvimento Sustentável. Esse reconhecimento evidencia a aplicação da verdadeira democracia participativa aos assuntos relativos ao meio ambiente, cujos princípios elementares constantes da Agenda 21 são:

a) o compromisso e a participação genuína de todos os grupos sociais terão uma importância decisiva na implementação eficaz dos objetivos, das políticas e dos mecanismos ajustados pelos Governos em todas as áreas de programas da Agenda 21; 
b) para alcançar o desenvolvimento sustentável é fundamental a ampla participação pública na tomada de decisões. No contexto mais especifico do meio ambiente e do desenvolvimento, surge a necessidade de novas formas de participação. Isso inclui a necessidade de indivíduos, grupos e organizações de participar em procedimentos de avaliação do impacto ambiental, de conhecer e participar das decisões que possam vir a afetar as comunidades nas quais vivem e trabalham. Individuos, grupos e organizações devem ter acesso à informação pertinente ao meio ambiente e desenvolvimento, inclusive sobre produtos e atividades que têm ou possam ter significativo impacto sobre o meio ambiente, e sobre medidas de proteção ambiental;

c) toda política, definição ou norma que afete o acesso das organizações não governamentais ao trabalho das instituições $e$ organismos das Nações Unidas relacionado com a implementação da Agenda 21, ou a participação delas nesse trabalho, deve aplicar-se igualmente a todos os grupos importantes;

d) as organizações não governamentais desempenham um papel fundamental na modelagem e implementação da democracia participativa. A credibilidade delas repousa sobre o papel responsável e construtivo que desempenham na sociedade. As organizações formais $e$ informais, bem como os movimentos populares, devem ser reconhecidos como parceiros na implementação da Agenda 21. A natureza do papel independente desempenhado pelas organizações não governamentais exige uma participação genuina; portanto, a independência é um atributo essencial dessas organizações e constitui condição prévia para a participação genuina.

É, portanto, vocação das Organizações Não governamentais, na qualidade de grupos organizados da sociedade civil, que representam ou defendam interesses difusos e públicos, sem fins lucrativos, coorporativos ou classistas, fortalecer os procedimentos democráticos na adoção de normas e políticas relativas ao meio ambiente. 
As Organizações Não Governamentais têm um papel importante no desenvolvimento da sadia qualidade de vida em âmbito mundial. As constantes manifestações em toda parte do globo, em movimentos conjuntos e coordenados, de forma reiterada, vêm mudando o quadro da população humana, não só nos aspectos ambientais, mas, também, sócio-econômicos, culturais e da saúde propriamente dita (PURIFICAÇÃO, 2001).

As Organizações Internacionais, por sua vez, podem ser definidas como associações voluntárias de Estados, constituídas através de um Tratado, com a finalidade de buscar interesses comuns por intermédio de uma permanente cooperação entre seus membros (SEINTENFUS e VENTURA, 1999). São organismos que reúnem Estados Soberanos para alcançar objetivos econômicos, sociais, culturais, políticos, entre outros, tendo competências e direitos que, por delegação instrumentalizada em tratado, receberam daqueles Estados. Tais organizações internacionais têm personalidade jurídica e atuam na órbita internacional, pois, em certa medida, equiparam-se aos Estados, por serem titulares de direitos e sujeito de deveres (DINIZ, 1998).

O papel das Organizações Internacionais está definido em tratados internacionais, protocolos de intenção e estatutos internos, sendo certo que o desenvolvimento progressivo destes objetivos ocorre em conferências para estipulação de metas e avaliação das realizações. Os objetivos traçados são delimitados e sofrem várias reformulações, conforme a necessidade para melhor consecução das propostas; importante ressaltar que as Organizações Internacionais não só possuem objetivos de auxílio ou construção de realidades mundiais mais justas, mas também correlatamente prestam informações acerca de seus trabalhos com fins de divulgação ou captação de recursos financeiros e humanos. 
A Organização das Nações Unidas - ONU, é a única organização em escala universal; pode-se dizer que é o único fenômeno de organização institucional da cooperação entre Estados, em matéria de política, de competência geral e vocação universal, da qual emanam a presença e ação na vida contemporânea das relações internacionais (STRENGER, 2002).

A ONU nasceu após a Segunda Gerra Mundial, com o propósito de cooperação entre as nações para evitar o conflito armado, buscando formular princípios para uma constante pacificação. Tem sua sede fixada na cidade de Nova York. Em 24 de outubro de 1945 foi constituida formalmente a Organização das Nações Unidas, pela Carta das Nações Unidas de 26 de junho de 1945, firmada inicialmente por 51 Estados (membros originários), sendo-lhe acrescentado, posteriormente e ao longo dos anos, membros admitidos, contando atualmente com 185 membros.

São funções primordiais da ONU: preservar a paz internacional, resolvendo os litígios entre os Estados; promover o respeito aos direitos humanos e à dignidade dos povos; fomentar o livre desenvolvimento e a autodeterminação das nações; entre outras funções de ordem social, econòmica, cultural e jurídica.

A ONU apresenta uma estrutura complexa, possui seis órgãos principais: Conselho de Segurança, Assembléia Geral, Conselho Econômico e Social, Conselho de Tutela, Secretariado e Corte Internacional ${ }^{100}$, os quais, para cumprimento de suas funções, podem criar órgãos subsidiários.

\footnotetext{
${ }^{100}$ A Corte Internacional de Justiça, foi estabelecida pela Carta da ONU como o principal órgão judiciário das Naçð̃es Unidas, é constituída de um corpo de 15 juízes independentes, eleitos pela Assembléia-Geral e pelo Conselho de Segurança e funciona permanentemente de acordo com as disposiçðes do seu Estatuto. Sua sede é em Haia e sua competência abrange todas as questões que as partes (Estados) the submetam, bem como todos os assuntos especialmente previstos na Carta das Naçð̃es Unidas ou em tratados e convençð̃es em vigor, sendo sua função decidir de acordo com o direito internacional as controvérsias que lhe forem submetidas (FONSECA, 2002).
} 
Existem várias organizações internacionais que atuam no mundo abarcando diversos assuntos de interesse internacional, destacando-se as Agências (especializadas e independentes) das Nações Unidas, cada qual com seus próprios membros, orçamento e sede, estudam os problemas, fazem sugestões e ajudam os países em desenvolvimento nos seus campos especificos de ação. São elas:

- FAO - Organização das Nações Unidas para Alimentação e Agricultura;

AIIA - Agência Internacional para a Indústria Atômica;

- UNESCO - Organizações das Nações Unidas para a Educação, Ciência e Cultura;

\ OMS - Organização Mundial da Saúde;

+ Banco Mundial (Banco Internacional para a Reconstrução e o Desenvolvimento - BIRD, Sociedade Financeira Internacional - SFI, Associação Internacional de Desenvolvimento - AID);

\FMI - Fundo Monetário Internacional;

- OIAC - Organização Internacional para a Aviação Civil;

- UIT - União Internacional para as Telecomunicações;

- OIM - Organização Internacional Marítima;

- OIT - Organização Internacional do Trabalho;

- OMM - Organização Mundial para a Meteorologia;

- ONUDI - Organização das Nações Unidas para o Desenvolvimento Industrial;

OMPI - Organização Mundial para a Propriedade Intelectual;

- FIDA - Fundo Internacional para o Desenvolvimento da Agricultura;

+ UNRWA - Agência das Nações Unidas para os Refugiados Palestinos do oriente Próximo;

+ OMC - Organização Mundial para o Comércio. 
Fruto das ações das Agências Especializadas da ONU, os Programas das Nações Unidas foram criados para atuarem em áreas específicas. São eles:

- UNICEF - Fundo das Nações Unidas para a Infância;

PAM - Programa Alimentar Mundial;

- UNCTAD - Conferência das Nações Unidas para o Comércio e o Desenvolvimento;

PNUD - Programa das Nações Unidas para o Desenvolvimento;

- FNUAP - Fundo das Nações Unidas para as Atividades sobre População;

- UNU - Universidade das Nações Unidas;

- UNEP (PNUMA) - Programa das Nações Unidas para o Ambiente;

+ CNUAH - Centro das Nações Unidas para os Assentamentos Humanos;

- INSTRAW - Instituto Internacional para a Investigação e a Formação sobre o Progresso das Mulheres;

UNHCR - Alto Comissariado para os Refugiados;

WCRP - Programa Mundial de Pesquisa sobre o Clima.

Intimamente ligadas às questões ambientais estão a FAO - Food and Agriculture Organization of the United Nations; a UNESCO - United Nations Educational, Scientific and Cultural Organization e o UNEP - United Nations Environment Programme.

A Organização das Nações Unidas para Alimentação e Agricultura (FAO) tem por escopo o cumprimento de projetos de melhoria do estado nutricional das populações, a produção e distribuição de produtos alimentares e agrícolas e as condições das populações rurais, com vistas também à conservação dos recursos naturais e à proteção ambiental nos setores agrícola e rural, através, principalmente, do Programa das Nações Unidas para o Desenvolvimento (PNUD). 
A Organizações das Nações Unidas para a Educação, Ciência e Cultura (UNESCO) tem seu interesse centrado nas questões educacionais, culturais, científicas e de comunicação, buscando, através de seus programas, as relações educativas entre meio ambiente e desenvolvimento.

O Programa das Nações Unidas para o Ambiente (UNEP/PNUMA), por meio de seus órgãos, tem como funções:

a) elaborar a política do meio ambiente;

b) coordenar os trabalhos em matéria de meio ambiente entre as demais Agências da ONU;

c) avaliar e analisar as pesquisas e infomações relativas ao meio ambiente;

d) fixar objetivos e planificar as consultas e acordos internacionais;

e) propor medidas de sustentação na educação e formação profissional;

f) organizar mecanismos de financiamento e cooperação técnica;

g) fomentar a conclusão e ratificação de tratados e o cumprimento dos princípios e acordos internacional de proteção ambiental.

O reconhecimento da importância das Organizações Internacionais nas questões ambientais vem claramente insculpido na Declaração das Nações Unidas sobre o Meio Ambiente Humano, na Conferência de Estocolmo, em 1972, que, em seu Princípio 25, dispõe: “Os Estados assegurarão que as organizações internacionais possam desempenhar um papel coordenado, eficiente e dinâmico, na proteção e melhoria do meio ambiente". Princípio este reafirmado na Declaração do Rio sobre Meio Ambiente e Desenvolvimento - ECO 92, especialmente em sua Agenda 21. 


\subsection{As normas técnicas ambientais}

Paralelamente às normas legais ambientais, em virtude da conscientização internacional da necessidade da implantação do desenvolvimento sustentado, surgiram as normas técnicas ambientais, algumas incorporadas pelas legislações internas e internacionais, outras com força equivalente, atribuída pelas leis de mercado nas relações econômicas entre as nações.

A Associação Brasileira de Normas Técnicas (ABNT) é órgão responsável pela normalização técnica no Brasil, entidade civil de direito privado, sem fins lucrativos, fundada em 1940. Integra o Sistema Nacional de Metrologia, Normalização e Qualidade Industrial, criado pela Lei $n^{\circ} 5.966 / 73$, e designada Foro Nacional de Normalização, no qual desempenha o papel de garantir a difusão das normas pelos setores social e econômico no Brasil, objetivando a elaboração de normas e desenvolvimento de atividades afins em âmbito nacional, buscando integrar os diversos interesses envolvidos: produtores, consumidores, usuários, entes governamentais, comunidade técnico-científica (MONTANHESI, 1997). Reconhecida como entidade de utilidade pública pela Lei $n^{\circ} 4.150 / 62$, a Associação Brasileira de Normas Técnicas tem como principais objetivos:

a) elaborar normas brasileiras e fomentar seu uso nos campos científico, técnico, industrial, comercial, agrícola, de serviços e outros correlatos, mantendo-as atualizadas;

b) incentivar e promover a participação das comunidades técnicas na pesquisa, no desenvolvimento e na difusão da normalização do país;

c) representar o Brasil nas entidades internacionais de normalização técnica;

d) colaborar com organismos similares estrangeiros, intercambiando normas e informações técnicas; 
e) colaborar com o Estado no estudo e solução dos problemas que se relacionem com a normalização técnica em geral;

f) conceder, diretamente ou através de terceiros, Marca de Conformidade e Certificado de Qualidade referentes a produtos e serviços;

g) prestar serviços no campo da normalização técnica;

h) intermediar junto aos poderes públicos os interesses da sociedade civil, no que respeita às questões de normalização técnica.

A Associação Brasileira de Normas Técnicas é representante do Brasil, mundialmente, nas seguintes entidades de normalização internacional: International for Standardization Organization (ISO), da qual é membro fundador, integrando vários Comitês Técnicos; International Electrotechnical Comission (IEC), organização responsável pela normalização internacional do setor eletrotécnico e na qual participa integrando diversos Comitês Técnicos, em especial, o Comitê de Tecnologia de Informação; Comissão Pan-Americana de Normas Técnicas (COPANT), organização regional que congrega a quase totalidade dos países americanos e, como membros aderentes, a Espanha, França, Itália, Portugal, entre outros paise europeus, na qual tem assento em todos os seus Comitês Técnicos e secretaria o Comitê de Produtos obtidos por Laminação e o Comitê de Minérios de Ferro; Comitê Mercosul de Normalização (CMN), participando de todos os Comitês Setoriais, com atribuições de estabelecer os Programas Setoriais de Normalização, conduzindo o processo de leboração de normas para posterior aprovação.

No âmbito interno, a Associação Brasileira de Normas Técnicas, atendendo designação do Ministério das Relações Exteriores, implantou, em 1994, o Projeto Qualidade Ambiental ABNT - Sistema de Certificação, que tem como objetivo a consolidação da ação articulada e consistente da ABNT, aplicada ao meio ambiente, no que respeita aos aspectos da infra-estrutura tecnológica voltados para a normatização, certificação, formação e treinamento e informação tecnológica e divulgação. 
A finalidade maior do Programa é a conscientização e a capacitação das empresas nacionais para as questões ambientais, para alertar e proporcionar instrumentos e mecanismos para incrementar a sua competitividade e para enfrentar as eventuais restrições ao livre exercício do comércio internacional.

Nos anos 90 se intensificaram a criação de selos verdes ${ }^{101}$. Na França foi criado o NF-ENVIRONMENTAL; na Índia, o ECO MARK; em Singapura, o GREEN LABEL. E a Bristish Standart Institution, entidade inglesa de normatização, desenvolveu a BS 7750, um sistema de normas de gestão ambiental para empresas do Reino Unido. Em 1994, a União Européia publicou uma regulamentação para todos os seus países-membros, criando uma norma para sistemas de gestão ambiental, como parte do seu Esquematização da Gestão e Auditoria Ambiental - EMAS.

As normas voluntárias, como a serie ISO 14000 , referentes à temática ambiental foram elaboradas pelo Comitê Técnico 207-TC 207, criado em 1993, pela ISO- International Organization for Standardization, destaque entre outras entidades internacionais de normalização ambiental. A ISO - International for Standardization Organization é uma organização internacional especializada, cujos membros são entidades normativas de âmbito nacional. Fundada em 1947 e sediada em Genebra na Suiça, tem por escopo o desenvolvimento de normas de fabricação, comércio e comunicações. No aspecto ambiental, as normas que desenvolve têm por objetivo criar sistema que permitam as organizações estabelecerem procedimentos para fixar uma politica ambiental e seus objetivos, atingir o cumprimento dos mesmos e demonstrar a terceiros que os atingiu. Pode-se dizer, assim, que as normas da ISO, em matéria ambiental têm, por finalidade, estabelecer diretrizes para implementação de sistema de gestão ambiental ${ }^{102}$ nas diversas atividades econômicas que possam afetar o meio ambiente e para a avaliação e certificação desses sistemas, com metodologias uniformes e aceitas universalmente (DONAIRE, 1999).

\footnotetext{
${ }^{101}$ Expressão genericamente utilizada em referência a diversos tipos de rotulagem ambiental, é o selo concedido a um produto cuja origem, processo e destinação final são ambientalmente sudáveis (MOUSINHO, 2003).

102 Sistema de gestão ambiental corresponde a um conjunto inter-relacionado de políticas, práticas e procedimentos organizacionais, técnicos e administrativos de uma empresa que objetiva obter melhor desempenho ambiental, e de controle e redução dos seus impactos ambientais (ROVERE, 2001).
} 
As normas ISO da série 14000 visam resguardar a qualidade ambiental do processo produtivo das empresas, a certificação, nesse caso, tem por escopo constatar se a empresa adota uma política ambiental implementada em conformidade com as exigências de determinado padrão. Essas normas não têm caráter vinculante, no entanto, estão sendo adotadas em quase todos os paises, sendo impossível, hoje, a exportação de produtos para países desenvolvidos sem o selo de qualidade ambiental (ISO 14000).

Os empresários buscam, cada vez mais, a adequação de suas empresas aos moldes dessas normas e, também, das legislações ambientais internas, para lograr conseguir esse selo, tornando-as competitivas tanto no mercado interno, como no mercado internacional (SIRVINSKAS, 2002). Dessa forma, a despeito de ser voluntária, a certificação por meio dessas normas ambientais torna-se importante para as empresas que desejam manter sua parcela no mercado.

De maneira diversa das leis e regulamentos legais técnico-ambientais, que são compulsórios e o seu não-cumprimento passível de penalidade, as normas editadas pela ISO são voluntárias e sua inobservância não acarreta sanções legais, porém, é o mercado quem dita as regras, muitas vezes fechando as portas para as regiões de grande interesse econômico pela ausência de atenção às normas ambientais voluntárias (ROVERE, 2001).

As normas possibilitam que as empresas que atendam aos requisitos, nelas especificados, obtenham o certificado de cumprimento a partir de uma auditoria $^{103}$. A certificação é realizada por um organismo certificador autorizado e permite que a empresa demonstre aos interessados a qualidade de seu sistema de gestão para melhor qualidade do meio ambiente ${ }^{104}$. $^{2}$

\footnotetext{
${ }^{103}$ Auditoria ambiental pode ser definida como uma análise sistemática, documentada, periódica e objetiva por entidades regulamentadas das operaçðes e práticas de uma instalação, relacionadas com o atendimento dos requisitos ambientais (TIBOR e FELDMAN, 1996).

${ }^{104}$ Meio ambiente é definido na ISO 14001 como os arredores no qual uma organização opera, incluindo ar, água, terra, recursos naturais, flora, fauna, seres humanos e suas inter-relaçð̌es; estendendo-se, o meio ambiente, do interior da organização até o sistema global (TIBOR e FELDMAN, 1996).
} 
Figura 25 - Sistema de Gestão Ambiental ${ }^{105}$ :

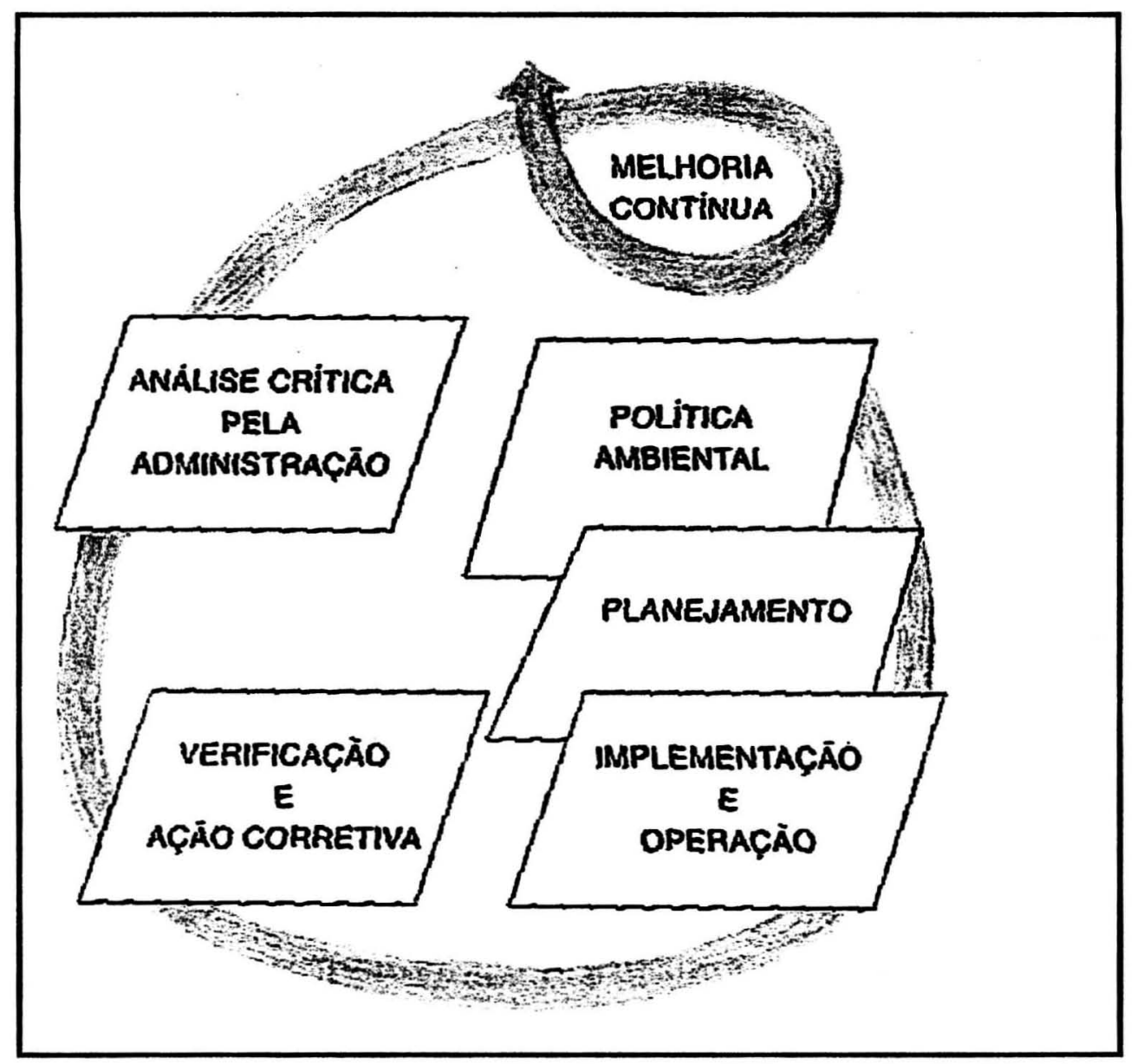

A Figura 25 demonstra, de forma simplificada, os principais elementos de um Sistema de Gestão Ambiental, sistema esse passível de integração com os demais objetivos da organizaçăo e plenamente aplicável a todos os tipos e partes de organizações, independentemente de suas condições geográficas, culturais e sociais. Essa proposta se apresenta com o objetivo de implantar um processo de melhoria contínua, com a pretensão de continuamente superar os padrões vigentes, cujo resultado de sua aplicação dependerá do comprometimento de todos os niveis e funções, em particular da alta administração da empresa (DONAIRE, 1999).

${ }^{105}$ Fonte: NBR ISO: 14001, ABNT, 1996 (DONAIRE, 1999, p. 117). 


\begin{abstract}
"A cobiça envenenou a alma dos homens, levantou no mundo as muralhas do ódio, e tem nos feito marchar a passos de ganso para a miséria e os morticínios. Criamos a época da velocidade, mas nos sentimos enclausurados dentro dela. A máquina que produz em abundância tem nos deixado na penúria. Nossos conhecimentos fizeram-nos céticos, nossa inteligência, empedernidos $\mathrm{e}$ cruéis. Pensamos em demasia e sentimos pouco. Mais do que máquinas, precisamos de humanidade. Mais do que inteligência, precisamos de afeição e doçura. Sem estas virtudes a vida será de violência e tudo estará perdido."106
\end{abstract}

\title{
5. EXIGIBILIDADE DOS TRATADOS INTERNACIONAIS DE PROTEÇÃO AMBIENTAL
}

\subsection{Validade interna dos tratados internacionais ambientais}

Tratado é um acordo internacional celebrado por escrito entre Estados e regido pelo direito internacional, quer conste de um instrumento único, quer de dois ou mais instrumentos conexos, qualquer que seja sua denominação particular. ${ }^{107} \mathrm{E} o$ ato jurídico pelo qual há a manifestação de vontades de duas ou mais pessoas internacionais, visando estabelecer um acordo (ACCIOLY e SILVA, 2002).

Tratado pode ser definido também como o acordo formal, concluído entre sujeitos de direito internacional público, e destinado a produzir efeitos jurídicos.

\footnotetext{
${ }^{106}$ Charles Chaplin, trecho do filme O grande ditador, 1940.

${ }^{107}$ Estatuto da Convenção de Viena, artigo $2^{\circ}$, inciso I, alínea $a$. Estabelece, ainda, que o direito de firmar tratados pode ser exercido também pelas demais pessoas internacionais, por sujeitos do direito internacional que não os Estados e organizaçס̃es intergovernamentais.
} 
A produção de efeitos jurídicos é essencial ao tratado, que não pode ser visto senão na sua dupla qualidade de ato juridico e de norma. $O$ acordo formal entre Estados é o ato jurídico que produz a norma, e que, justamente por produzi-la, desencadeia efeitos de direito, gera obrigações e prerrogativas, caracterizando, na plenitude de seus dois elementos, o tratado internacional. É a norma juridica produzida mediante um ato de vontade estatal num contexto em que se presume a igualdade formal entre as partes, ato que consuma uma relação jurídica de direito internacional e que funda a obrigatoriedade da aplicação da norma internacional mediante os principios do pacta sunt servanda ${ }^{108}$ e da boa-fé, sendo este conceito fundamental na determinação da posição hierárquica e na dinâmica das normas oriundas dos tratados no contexto da unidade que é o Direito (REZEK, 1996).

Os tratados ${ }^{109}$ internacionais, enquanto acordos internacionais juridicamente obrigatórios e vinculantes, constituem a principal fonte de obrigação do Direito Internacional (PIOVESAN, 1996).

Compete ao Chefe do Poder Executivo, ou representante por ele designado, celebrar tratados, entretanto, sobre cada país é a Constituição que vai determinar uma competência exclusiva ou privativa, ou até mesmo, uma divisão de competências para a vigência do tratado internacional na ordem interna.

\footnotetext{
${ }^{108}$ Princípio segundo o qual o que foi pactuado deve ser cumprido - é um modelo de norma fundada no consentimento perceptivo; é o dever de honrar as obrigaçðes livremente assumidas.

${ }^{109}$ O termo tratado é aqui empregado em seu sentido genérico, usado para incluir as convenções, os pactos, as cartas e demais acordos internacionais. Em significaçăo propriamente juridica, é o convênio, o acordo, a declaração, ou o ajuste firmado entre duas, ou mais naçð̃es, em virtude do que as signatárias se obrigam a cumprir e respeitar as cláusulas e condiçð̌es que nele se inscrevem como se fossem verdadeiros preceitos de Direito Positivo. Em sentito estrito, tratado é o acordo de maior importância por seu objeto, que firma definitivamente uma situação jurídica, ou que se destina a durar longamente. Os tratados podem ser divididos em tratados-contratos e tratados-leis ou tratadosnormativos. Os tratados-leis são geralmente celebrados entre muitos Estados com o objetivo de fixar normas de Direito Internacional Público. Os tratados-contratos procuram regular interesses recíprocos e são geralmente de natureza bilateral, mas existem diversos exemplos de tratados multilaterais ou de tratados multilaterais restritos, podendo reunir as duas qualidades. $O$ tratado difere da convenção e da declaração, sendo que a convenção é o acordo sem objetivo político e a declaração, por sua vez, o acordo que vem afirmar um principio (DE PLÁCIDO E SILVA, 1997).
} 
Há dois diferentes sistemas de conclusão dos tratados: o da concentração de poderes e o da separação de poderes. O primeiro consiste na fusão dos Poderes Executivo e Legislativo, sendo o órgão resultante de tal fusão competente para a ratificação dos tratados. Um exemplo é o sistema britânico, em que a ratificação integra as prerrogativas e faculdades da Coroa, mas na prática, além de ser ouvido o Governo, o Parlamento é sempre consultado antes da ratificação, e esta ocorre automaticamente passadas três semanas, se nenhum parlamentar suscitar sua discussão. O segundo sistema, mais usual, é o da separação de poderes, no qual a ratificação é dada pelo Chefe de Estado, no entanto, mediante prévia aprovação do órgão legislativo. Em regimes presidencialistas, esta aprovação pelo órgão legislativo deve ocorrer em relação a todos os tratados. É o caso dos Estados Unidos e também da Argentina. Os tratados convencionais exigem sempre a participação do Poder Legislativo, no que concerne à aprovação ou referendo, para sua vigência no direito interno, mediante a emissão de um Decreto Legislativo (GRUPENMACHER, 2002).

A Constituição Federal prevê a necessária colaboração entre os Poderes do Estado, sendo da União a competência para manter relações com Estados estrangeiros e participar das organizações internacionais; atribui competência privativa ao Chefe do Poder Executivo para a celebração dos tratados internacionais, de forma a representar a União na Ordem Internacional, mas os compromissos assumidos pelo Chefe do Poder Executivo ficam sujeitos a aprovação ou referendo do Poder Legislativo: consagra-se o preceito de que quem tem a voz externa do Estado é o Chefe do Poder Executivo, cabendo apenas a este, a celebração, a ratificação e a promulgação dos tratados celebrados, incumbindo ao Poder Legislativo a aprovação e o referendo dos compromissos já mencionados ${ }^{110}$.

Para que um tratado seja concluído, ele tem que respeitar algumas formalidades, sendo quatro as fases para a sua definitiva conclusão:

\footnotetext{
110 Art. 49. É da competência exclusiva do Congresso Nacional: I - resolver definitivamente sobre tratados, acordos ou atos internacionais que acarretem encargos ou compromissos gravosos ao patrimônio nacional (...). Art. 84. Compete privativamente ao Presidente da República: (...) VIII celebrar tratados, convençðes e atos internacionais, sujeitos a referendo do Congresso Nacional.
} 
a) as negociações preliminares,

b) a assinatura ou a adoção pelo Executivo,

c) a aprovação parlamentar, e

d) a ratificação ou adesão do texto do tratado.

No Brasil, após a ratificação, o presidente da República promulga o tratado através de um decreto e também o publica no Diário Oficial da União.

Em regra, a iniciativa da negociação sempre parte do Estado que mais interessado está com a conclusão do tratado. Caso o tratado seja multilateral, a negociação poderá ser realizada de duas formas: ou ela será realizada numa Organização Internacional, ou haverá uma convocação coletiva para uma conferência internacional, para que se discuta o tratado. As negociações terão seu início com base num texto de tratado já estabelecido em forma de um projeto, o qual será a base para a conversação entre os Estados contratantes. Se as partes contratantes estiverem de acordo com o texto do tratado, procede-se à assinatura, sendo que esta é apenas uma forma de manifestar a vontade, não sendo ela a aceitação definitiva do tratado. A assinatura é obrigatória, uma vez que é com ela que se encerram as negociações e se demonstra o consentimento do Estado em participar do tratado. Além disso, depois de assinado o tratado, não poderá ser realizada nenhuma alteração no texto, com exceção das reservas.

No Brasil, segundo o Ministério das Relações Exteriores, qualquer autoridade pode assinar um tratado, desde que ela possua a carta de plenos poderes, firmada pelo Presidente da República e referendada pelo Ministro das Relações Exteriores. Após ser assinado o tratado, o Poder Legislativo apreciará e poderá aprovar ou não o texto, sendo este ato realizado obrigatoriamente antes da ratificação do Chefe do Executivo. Uma vez aprovado o tratado pelo Parlamento, o texto retornará ao Poder Executivo para que ocorra a ratificação ${ }^{111}$ (RANGEL, 1993).

\footnotetext{
${ }^{111}$ Do latim "ratificare", "ratum facere", "ratum esse", que significa tornar válido. No âmbito em estudo, é o ato administrativo unilateral através do qual o Estado, sujeito de direito internacional, confirmando a assinatura do acordo, aceita definitivamente as obrigações internacionais que assumiu, irradiando, necessariamente, efeitos no plano internacional (MAZZUOLI, 2001).
} 
Após a aprovação do tratado, o governo pode ou não ratificá-lo, julgando o que for mais conveniente para o país. A ratificação não pode ser feita de maneira tácita, por ser um ato de extrema formalidade, ao ratificar um tratado, o Estado assume as obrigações de:

a) respeitar, fazer respeitar e garantir os direitos reconhecidos pelo texto a toda pessoa sujeita à jurisdição;

b) adaptar sua legislação interna ao estabelecido no tratado;

c) assegurar que suas autoridades não tomem medidas ou ações que vão contra o disposto no tratado;

d) colocar à disposição de toda pessoa que se sinta violada em seus direitos, recursos juridicos efetivos para corrigir a situação (MAZZUOLI, 2001).

Como se verifica, o tratado é um ato complexo. Não obriga o país assinante a observá-lo e cumpri-lo perante as relações jurídicas que forem travadas dentro do seu foro interno, enquanto não for integrado ao ordenamento jurídico interno, obrigando, nesse interim, apenas o país, no que concerne às relações internacionais que venha a manter com os outros países assinantes.

Essa integração, para a vigência dos tratados e produção de todos os seus efeitos no ordenamento jurídico interno, mister se faz que estes sejam referendados ou ratificados pelo Congresso Nacional, por meio de decreto legislativo, sendo certo que a eficácia depende, ainda, da futura edição de decreto do Presidente da República (FARIA, 2002).

É a conjugação dos Poderes Legislativo e Executivo, independentes e harmônicos entre si, que permite aos tratados produzirem seus efeitos, consagrando a colaboração entre o Executivo e o Legislativo na conclusão de tratados internacionais, que não se aperfeiçoa enquanto a vontade do Poder Executivo, manifestada pelo Presidente da República, não se somar à vontade do Congresso Nacional (PIOVESAN, 1996). 
Os tratados constituem, portanto, espécie de norma juridica especialissima no que diz respeito à forma de constituição e peculiar quanto à sua posição estática e/ou dinâmica em dada ordem juridica nacional, entretanto, é uma norma juridica como qualquer outra no que diz respeito à sua finalidade pragmática de incidência sobre a realidade social, pois uma vez consumada a sua introdução em determinado ordenamento jurídico, portanto, vigente e eficaz, o seu destino será a aplicação (PIOVESAN, 1996).

No contexto internacional, em que surgem os tratados internacionais, se fazem presentes as seguintes condicionantes: descentralização, coordenação, horizontalidade e consentimento. A esse respeito é entendimento que sociedade internacional, ao contrário do que sucede com as comunidades nacionais organizadas sob a forma de Estados, é descentralizada; assim, a idéia de subordinação que marca a ordem jurídica interna não encontra paralelo na ordem internacional, onde a coordenação é o princípio que preside a convivência organizada de tantas soberanias, ou seja, no plano internacional não existe autoridade superior, os Estados se organizam horizontalmente, e prontificam-se a proceder de acordo com normas jurídicas na exata medida em que estas tenham constituído objeto de seu consentimento.

A criação de normas é, portanto, obra direta de seus destinatários, não há representação, como no caso dos parlamentos nacionais que se propõem exprimir a voz dos povos, nem prevalece o princípio majoritário.

A vontade singular de um Estado soberano somente sucumbe para dar lugar ao primado de outras vontades reunidas quando aquele mesmo Estado tenha, antes, abonado a adoção de semelhante regra, qual sucede no quadro das organizações internacionais, a propósito de questões de importância secundária, em virtude de tais condicionantes não há vinculação ao princípio majoritário, ou seja, cada vontade singular vincula-se na exata medida de seus interesses particulares (REZEK, 1996). 
Dessa forma, o direito internacional impõe obrigações e deveres aos Estados no que concerne a determinadas condutas, atribuindo ao direito interno uma determinação de dever, no que se refere à conduta dos indivíduos ${ }^{112}$. Essa determinação em âmbito interno pode ser recepcionada de diversos modos pelo direito nacional. Vejamos:

a) unidade de ordenamentos: as ordens internacional e interna seriam $u m a^{113}$. Nesse caso, o Estado ao obrigar-se na ordem internacional, utiliza-se de sua soberania, a qual é reconhecida pela ordem internacional e estende-se aos indivíduos subordinados a este Estado, passando os mesmos a sujeitos de direitos e obrigações internacionais.

b) separação entre a ordem internacional e a ordem interna ${ }^{114}$ : a ordem internacional regula as relações entre os Estados, enquanto a ordem interna regula a convivência civil entre os indivíduos de um determinado Estado.

\footnotetext{
${ }^{112}$ Hasta ahora se habia supuesto que en el momento en que se actualiza la obligación internacional de un Estado, la constitución de este Estado ya contiene la designación de los órganos que han de cumplir con la obligación internacional. Pero también es posible que el ordem jurídico del Estado no contenga todavia una norma que designe el individuo que, como órgano del Estado, ha de cumplir con la obligación internacional. En tal caso, ha de crearse esa norma. La situación es la misma si la norma de Derecho Internacional obliga al Estado a cierta conducta pero la designa tan sólo en términos generales, de tal manera que sea necesario hacer outras determinaciones para ilevar a cumplimiento esta norma del Derecho Internacional. En este caso, se debe dictar una norma nacional para ampliar o completar la norma de Derecho Internacional, porque la conducta de los órganos del Estado que deben cumplir los deberes internacionales de este tiene que estar determinada de modo adectuado. También se debe dictar una norma de Derecho Nacional para la ejecución de una norma de Derecho Internacional cuando los órganos del Estado, que deben cumplir los deberes internacionales de éste, pueden, según la constitución, ejecutar únicamente normas de Derecho Nacional. (KELSEN, 1965).

${ }^{13}$ Teoria monista: segundo a qual existe uma única espécie de ordem jurídica, envolvendo tanto a ordem interna como a ordem internacional. Com a prevalência, para alguns, do direito interno monismo com primazia do direito interno, caracterizando a absoluta soberania do Estado. E, para outros, a prevalência do direito internacional - monismo com primazia do direito internacional, já que a ratificação de um tratado internacional produz a sua vigência nos direitos internacional e interno, ocasionando uma produção de direito e obrigaçðes, tanto para o Estado, como para os indivíduos (MELLO, 2002).

114 Teoria dualista: preceitua a existência de duas ordens jurídicas distintas, sendo uma nacional e outra internacional, sendo necessária a emissão de uma norma de caráter especial que produza no direito pátrio o disposto na norma internacional. Alguns sistemas jurídicos optam pela técnica da incorporaçăo legislativa, enquanto outros o fazem pela simples ratificação do tratado internacional, para sua aplicação no direito interno (MELLO, 2002).
} 
c) equivalência dos tratados às normas constitucionais ${ }^{115}$ : sistema aberto de direitos fundamentais no Brasil, no qual o parâmetro da constitucionalidade não se reduz positivisticamente às regras e princípios escritos nas leis constitucionais; alarga-se também a outros princípios não expressamente consignados na constituição, desde que tais principios ainda se possam incluir no âmbito normativoconstitucional (CANOTILHO, 1993).

Note-se que a discussão sobre ambas as doutrinas (monista e dualista, expostas nas alíneas $a$ e $b$, acima) perdeu o sentido ante a dinâmica que envolve as relações internacionais nos dias atuais: a Constituição de cada Estado determina as regras para incorporação dos tratados internacionais ao direito interno. A questão se cinge ao exame da Constituição do país e dos mecanismos por ela adotados para a celebração e ratificação dos tratados, deve-se sempre examinar a Constituição para se verificar a constitucionalidade de um tratado e, assim, sua regularidade perante a ordem interna (MAGALHÃES, 2000).

Este é um conceito não jurídico e designa um mecanismo de tornar uma norma elaborada num ambiente internacional, em norma interna dos Estados, na técnica jurídica do Direito Internacional Público clássico, tal procedimento se denomina incorporação ${ }^{1 / 6}$ (SOARES, 2001).

$\mathrm{O}$ artigo $5^{\circ}$ e respectivos parágrafos, da Constituição Federal Brasileira, dispõem sobre os direitos e garantias individuais, o que não exclui outros decorrentes dos princípios e do regime adotado, além dos princípios expressos há também princípios implicitos. Vejamos:

\footnotetext{
115 Teoria da parametricidade do direito suprapositivo: a ordem constitucional global é entendida como mais vasta do que a constituiçăo escrita, pois abrange não apenas os princípios jurídicos fundamentais informadores de qualquer Estado de direito, mas também os princípios implícitos nas leis constitucionais.

${ }^{116} \mathrm{~A}$ incorporaçăo pode ser automática, como na Commow Law da Inglaterra em que se considera que Internacional Law is a part of the law of the Land, ou dependente de um ato expresso dos Poderes do Estado, seja pelo passamento de uma lei especial, ou por um procedimento próprio de aprovação do texto internacional pelo Poder Legislativo e posterior promulgação pelo Poder Executivo, por meio de um Decreto, como ocorre no Brasil (SOARES, 2001).
} 
Art. $5^{\circ}$. Todos são iguais perante a lei, sem distinção de qualquer natureza, garantindo-se aos brasileiros e aos estrangeiros residentes no País a inviolabilidade do direito à vida, à liberdade, à igualdade, à segurança è à propriedade, nos termos seguintes: (...)

$\S 1^{\circ}$ As normas definidoras dos direitos e garantias fundamentais têm aplicação imediata.

$\S 2^{\circ}$ Os direitos e garantias expressos nesta Constituição não excluem outros decorrentes do regime e dos princípios por ela adotados, ou dos tratados internacionais em que a República Federativa do Brasil seja parte.

Os direitos fundamentais expressos, direitos fundamentais implícitos e direitos fundamentais decorrentes do regime e de tratados internacionais, apesar de não rotulados expressamente como fundamentais no título próprio da Constituição, podem ser como tais considerados, em razão da análise do seu objeto e dos princípios adotados por ela. Essa sua fundamentalidade decorre diretamente da sua referência a posições jurídicas ligadas ao valor da dignidade humana, que, por sua importância, não podem ser deixadas à disponibilidade absoluta do legislador ordinário. Isto porque os direitos fundamentais não são a sobra de tudo o que o homem não pode fazer, mas o núcleo mínimo resistente no qual estão cristalizados os direitos essenciais à dignidade de qualquer pessoa humana (SILVA, 2000).

Dessa forma, os direitos fundamentais previstos nos tratados assinados e ratificados pelo Brasil gozam, não apenas da condição de normas constitucionais fundamentais, como também integram, ao lado dos direitos e garantias expressos na Constituição, o rol das matérias constitucionais imodificáveis por emenda constitucional - as chamadas cláusulas pétreas (TRINDADE, 1991). Ademais, como os tratados internacionais se prestam a não abolir (como também a não restringir) os direitos e garantias, não há porque não admiti-los como normas constitucionais. Vale dizer, se é certo que as normas restritivas devem ser interpretadas restritivamente, também é certo que as normas garantidoras devem ser interpretadas extensivamente (MAXIMILIANO, 2001). 
Os tratados ou convenções internacionais, uma vez regularmente incorporados ao direito interno, situam-se, no sistema jurídico brasileiro, nos mesmos planos de validade, de eficácia e de autoridade em que se posicionam as leis ordinárias, havendo, em conseqüência, entre estas e os atos de direito internacional público, mera relação de paridade normativa, não havendo primazia hierárquica sobre as normas de direito interno. A eventual precedência dos tratados ou convenções internacionais sobre as regras infraconstitucionais de direito interno somente se justificará quando a situação de antinomia ${ }^{117}$ com o ordenamento doméstico impuser, para a solução do conflito, a aplicação alternativa do critério cronológico ou, quando cabível, do critério da especialidade (BAPTISTA, 2002).

Convém ressaltar, porém, que não basta verificar a constitucionalidade de um tratado, pois há também que se ter em conta a compatibilidade da própria Constituição com as normas cogentes de Direito Internacional, de aplicação geral e obediência compulsória por todos os Estados, por expressarem valores permanentes da comunidade internacional. Dentre estes estão os que dizem respeito aos Direitos Humanos que prevalecem sobre eventuais valores de comunidades nacionais com eles contrastantes (GRINOVER, 2002).

O entendimento é de que a Constituição Federal de 1988, adotou para os tratados de direitos e garantias fundamentais e os tratados de direitos humanos o preceito da incorporação imediata ao direito interno: os direitos humanos consagrados em tratados de direitos humanos em que o Brasil seja parte incorporamse 'ipso facto' ao direito interno brasileiro, no âmbito do qual passam a ter 'aplicação imediata', da mesma forma e no mesmo nível que os direitos constitucionalmente assegurados. A especificidade e o caráter especial dos tratados de direitos humanos encontram-se, portanto, devidamente reconhecidos pela Constituição brasileira vigente (TRINDADE, 1991).

\footnotetext{
117 Antinomia pode ser definida como conflito de normas. São critérios de solução do eventual conflito: cronológico (a norma mais nova prevalece sobre a norma mais antiga), hierárquico (a norma hierarquicamente superior prevalece sobre a norma hierarquicamente inferior) e da especialidade (a norma especial prevalece sobre a norma geral).
} 
A Constituição, nesse dispositivo, não menciona a lei, mas os direitos e garantias por ela, Constituição, assegurados, ou por tratados internacionais de que o Brasil seja parte. Há, aqui, verdadeira equiparação entre a Constituição e os tratados. Dessa forma, se a Constituição não previu certos direitos e garantias, contemplados em tratados firmados pelo Brasil, tais direitos e garantias se sobrepõem à leis que não os reconheçam, por força da própria Constituição. O dispositivo é claro sobre essa equiparação. Assim, se a lei estabelecer determinado direito ou garantia, não incluído dentre os estabelecidos no artigo $5^{\circ}$, tal lei poderá ser revogada por outra, sem ferir a Constituição. Mas se tal direito ou garantia for assegurado por tratado, a lei não poderá revoga-los, diante da equiparação constitucional estabelecida no citado dispositivo (MAGALHÃES, 2000). É, portanto, inequívoca a isonomia entre a Constituição Federal e os Tratados Internacionais de Direito Humanos ${ }^{118}$.

O que se nota da Constituição Federal de 1988, é que o constituinte optou por um sistema misto, no que concerne aos tratados internacionais, dispensando um tratamento específico para os tratados legislativos ou tratados convencionais, com a teoria da paridade com a lei ordinária federal, enquanto, por outro lado, atribui aos tratados de direitos fundamentais e direitos humanos um tratamento diferenciado, concede-lhes o caráter de norma constitucional (CANOTILHO, 1993).

Em síntese, o tratado internacional é norma que surge de um ato de vontade do Estado, ato este que uma vez celebrado e devidamente concluído em todos os seus termos formais ocasionará a fundação de um pacto que deve ser cumprido obrigatoriamente e de boa-fé; no contexto do direito brasileiro poderá ingressar em três níveis possíveis, como equivalente à lei complementar, como norma inferior à lei complementar, mas superior à lei ordinária, e, como equiparável à lei ordinária, distinções essas de interesse exclusivo no âmbito do direito interno (MAGANO, 2002).

\footnotetext{
118 Acredita-se que conferir grau hierárquico constitucional aos tratados de direitos humanos, com a observância do princípio da prevalência da norma mais favorável, é interpretaçăo que se situa em absoluta consonância com a ordem constitucional de 1988 , bem como com sua racionalidade $e$ principiologia. Trata-se de interpretação que está em harmonia com os valores prestigiados pelo sistema jurídico de 1988, em especial com o valor da dignidade humana - que é valor fundante do sistema (MAZZUOLI, 2001).
} 
Deve-se considerar que os tratados envolvem outros membros da comunidade internacional, e estes negociam de boa-fé suas obrigações internacionais e não esperam que a legislação interna lhes seja contrária, como exceção para não cumprir com os compromissos internacionais - princípio de reciprocidade ${ }^{119}$, elemento básico no processo de integração.

A Convenção de Viena dispõe que uma parte pode invocar a impossibilidade de cumprir um tratado como causa de extinção ou de retirada, se esta impossibilidade resultar da destruição ou do desaparecimento definitivo de um objeto indispensável à execução do tratado. Se a impossibilidade for temporária, pode ser invocada somente como motivo para suspender a execução do tratado.

A impossibilidade de cumprimento não pode ser invocada por uma das partes como causa de extinção, de retirada ou de suspensão da execução do tratado, se essa impossibilidade resulta de uma violação pela parte que invoca, de uma obrigação do tratado, ou de qualquer outra obrigação internacional em relação a qualquer outra parte do tratado.

Estabelece, ainda a Convenção que, uma mudança fundamental de circunstâncias, ocorrida em relação àquelas existentes no momento da conclusão do tratado e não prevista pelas partes, não pode ser invocada como causa para a extinção ou retirada do tratado, salvo se:

\footnotetext{
119 O princípio pressupõe o abandono de regras positivas, uma vez que estão acima delas, sendo o principio norma que orienta a elaboração de outras normas, de primeiro grau, extraída, por deduçăo do sistema normativo, operando limitação das próprias normas e integração do sistema. Assim, princípios gerais de direito comunitário são regras gerais de incidência sobre situaçð̃es fáticas, no caso, situaçð̃es que envolvem o relacionamento entre Estados soberanos, incidindo sobre mais de um ordenamento normativo. Nesse passo, pode-se dizer que não são regras sobre comportamentos especificos, mas regras que incidem sobre comportamentos comuns subordinados ao mesmo tempo a alguns sistemas positivos de direitos, mas também a um sistema suprapositivo revocatório do direito local (BOBBIO, 1997). A existência de princípios implícitos ou explicitados significa que há vetores e regras de comportamento conectados com a natureza humana - certos comportamentos que são plenamente aceitos pelo homem em decorrência de sua própria natureza. Os princípios, que por si só são gerais, pressupðem sua aplicação independente de texto normativo, impondo-se o tratamento recíproco isonômico, tornando, dessa forma, fundamental o princípio da reciprocidade de tratamento na relação entre estados soberanos (OLIVEIRA, 2002).
} 
a) a existência dessas circunstâncias tiver constituído uma condição essencial do consentimento das partes em obrigarem-se pelo tratado; e

b) essa mudança tiver por efeito a transformação radical da natureza das obrigações ainda pendentes de cumprimento em virtude do tratado.

Não pode, entretanto, uma mudança fundamental de circunstâncias ser invocada como causa para a extinção ou retirada do tratado:

a) se o tratado for de limites; ou

b) se a mudança fundamental resultar de violação, pela parte que a invoca, seja de um tratado seja de qualquer outra obrigação internacional em relação às outras partes no tratado.

Se, nos termos dos itens anteriores, uma parte pode invocar uma mudança fundamental de circunstâncias como causa para extinção ou retirada do tratado, pode também invocá-lo para para suspender a execução do tratado.

Assim, eventual revogação de tratados por meios constitucionais e infraconstitucionais que não sejam os previstos na própria convenção, implicam na prática de ilícito internacional passível de justa reparação.

O Estado, em seu âmbito jurídico interno pode, eventualmente, revogar tratado, mas não deve em respeito ao Direito, que o vincula desde a seara externa, pelo tratado, e desde a seara interna pela soberania e a honra nacionais colocadas na manifestação de vontade instituidora do dever de cumprimento.

Dessa forma, embora o direito internacional seja silente quanto à maneira como suas regras se incorporam ao direito interno do Estado, as modalidades da aplicação do direito internacional na ordem interna são, em geral, igualmente deixadas ao arbítrio dos Estados, que têm adotado, nesse ponto, soluções muito diferentes (FARIA, 2002). 
Entretanto, o elemento essencial do direito internacional é o compromisso entre Estado e sociedade internacional ${ }^{120}$. De um lado estão os Estados como sujeitos do direito das gentes, e de outro, os interesses da sociedade internacional no seu todo, podem ocorrer divergências e colidências, mas a interação entre ambas as esferas é inevitável, para que possa existir direito internacional e, desse modo, para que possam os Estados se relacionar uns com os outros (CASELLA, 2002).

O artigo 30 da Carta da OEA - Organização dos Estados Americanos dispõe que a cooperação interamericana para o desenvolvimento integral é responsabilidade comum e solidária dos Estados-membros no marco dos princípios democráticos e das instituições do Sistema Interamericano. Ela deve compreender os campos econômico, social, educacional, cultural, científico e tecnológico, apoiar a consecução dos objetivos nacionais dos Estados-membros e respeitar as prioridades que se fixe em cada País, em seus planos de desenvolvimento, sem amarras nem condições de caráter político.

Os Estados reconhecem o direito internacional, contudo os princípios que dele promanam se interpretam de muitas maneiras, tendo em vista as diversidades interpretativas de palavras como democracia, autodeterminação, direitos humanos, guerra ofensiva e defensiva, demonstrando que as palavras por si só não logram fundamentar autênticos vínculos, se prescindem dos valores que existem por trás das palavras $^{121}$ (STRENGER, 2002).

\footnotetext{
${ }^{120}$ Convención es la concordância de voluntades de dos o varios sujetos, tendiente a producir um efecto jurídico, es decir a crear o extinguir uma obligación y el derecho subjetivo correspondiente; la convención tiene, por su misma naturaleza, esa cualidade que denominamos 'fuerza obligatoria', y los sujetos adquieren, a consecuencia de lo estipulado, obligaciones y derechosde que anteriormente carecían. LAs cláusulas de un tratado internacional tienen sentido em la medida em que se hallan dentro del âmbito de lo normativo; se trata de normas juridicas, esto es de normas que prescriben juridicamente uma conducta humana como permitida, prohibida u obligatoria (GUARDIA, 2002).

${ }_{121}$ No importa unicamente conocer si uma determinada norma es válida por el hecho de Haber sido estabelecida de acuerdo com las fuentes de producción jurídica de um ordenamiento dado; em el proceso de formación de las normas, la observación de la realidad nos muestra que han existido intereses contrapuestos, presentes em las relaciones entre determinados sujetos, $y$ que estos intereses determinan el contenido de la norma y de los valores que ésta pretende realizar o satisfacer. Las normas em el derecho internacional son el fruto de uma acomodación recíproca, de uma actitud razonable y de um espíritu de cooperación entre los Estados (PIERNAS, 2002).
} 
No que respeita aos tratados ambientais, deve-se considerar, também, que o crescimento econômico e desenvolvimento não são suficientes para determinar melhores condições de vida; a degradação do ambiente incide de modo muito negativo sobre a qualidade de vida dos cidadãos e, conseqüentemente, a proteção do ambiente não é vista apenas como uma finalidade, mas como condição primária da própria subsistência. Os ventos, a chuva, o ar, os rios, alcançam dois ou mais países e podem ocasionar efeitos diversos, exigindo providências conjuntas e, muitas vezes urgentes (FREITAS, 2001).

Nesse particular, é inquestionável a importância das normas ambientais internacionais $^{122}$, no entanto, não se pode ignorar a realidade da maioria dos países e, por conseguinte, a premência em adequar o desenvolvimento com a proteção que se quer implantar, sendo necessário, na aplicação da norma específica, ponderar sua viabilidade, ou seja, a aplicação das leis e dos princípios internacionais que regem a política de proteção ambiental, de forma coerente, levando-se em consideração as atividades peculiares existentes em cada região, de forma que não se agrida e nem se prejudique todo um setor da comunidade, preservando-se, de forma efetiva, o ideal em um equilibrado desenvolvimento sustentado (VIANA, 2002).

\subsection{Efetividade do direito ambiental internacional e soberania}

Soberania é conceito que em Ciência Política pode significar sinonimia de estado de natureza, fundamentando a existência de uma sociedade internacional das nações, pela renúncia de cada pessoa de direito internacional de parcelas não essenciais de seu estado de natureza.

\footnotetext{
${ }^{122}$ The consensus play a fundamental role in the process of formation and evolution of international law as it is only too evident in the case of the various global commons discussed. A good number of the new approaches and conceptual innovations are rapidly being incorporated into the body of international law, mostly by means of specific regimes but also occasionally by means of the development of new basic rules at the general level of the law, all of it to the extent that consensus has been reached. Some suggestions and attempts have not met this essential requirement and have consequently failed (VICUÑ
} 
Segundo a teoria de Thomas Hobbes, os homens em estado de natureza iriam perceber, em seus momentos de reflexão, que a lei da natureza os obriga a renunciar a seu direito de julgamento privado do que é perigoso em casos dúbios, e a aceitar por si mesmos o julgamento de uma autoridade comum, substituindo o termo homem por Estado teremos a Ordem Pública Internacional (VIGNALI, 1995).

No conceito jurídico, por soberania entende-se o poder supremo politico de um Estado, ou poder que se sobrepõe ou está acima de qualquer outro, não admitindo limitações, exceto quando dispostas voluntariamente por ele, Estado, ao firmar tratados internacionais (SILVA, 1997).

Assim, no campo internacional, coexistem muitos soberanos, os quais, ao ter que se relacionarem, criam um sistema de coordenação, desenvolvido a partir da idéia de compromissos mútuos e obrigação de cumpri-los de boa-fé (VIGNALI, 1995).

A autonomia do poder estatal está justamente para evitar qualquer vinculação do estado com qualquer outro ente. Ele existe como construção social, uma vez que para que possamos constituir uma sociedade ordenada, esta delegou e conferiu força e poder ao Estado para que organize a sociedade, estabeleça normas de convivência e suplante eventuais conflitos sociais, firmando-se a tripartição dos poderes estatais, com base na teoria de Montesquieu ${ }^{123}$. O poder estatal é político pela necessidade evidente de edificação de uma rede de serviços em prol da sociedade, nele reside a capacidade de estabelecer normas dotadas de imperatividade, fruto do poder de império do Estado, para a mantença do controle social, sendo que a supremacia do poder político reside na impossibilidade da coexistência de duas ordens supremas dentro do mesmo contexto social, sob pena de antinomias surgirem e uma fratura na legitimidade das ordens estatais. Dessa sorte, o poder estatal não conseguiria manter para si um grau de força na manutenção do controle social e muito menos, suplantar as crises que adviriam da inexistência ou divisão do poder do Estado no âmbito interno (SILVA, 2000).

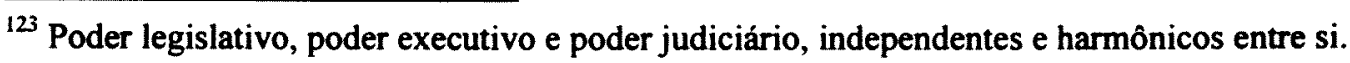


O Estado não se subordina a qualquer autoridade que the seja superior, não reconhece, em última análise, nenhum poder maior de que dependam a definição e o exercício de suas competências, e só se põe de acordo com seus homólogos na construção da ordem internacional, e na fidelidade aos parâmetros dessa ordem, a partir da premissa de que aí vai um esforço horizontal e igualitário de coordenação no interesse coletivo (REZEK, 1996).

Porém, na atualidade, a limitação da soberania surge como mecanismo de manutenção da ordem social.

A soberania dos Estados, inclusive dos mais poderosos, encontra limitações resultantes da coexistência entre eles, bem como da soberania concorrente de outros Estados, principalmente, em um mundo cada vez menor e interdependente. Nem mesmo as grandes potências podem resolver ao alvedrio os problemas que lhes são concernentes, nem podem comportar-se como queiram, pois são partícipes de uma sociedade e, por isso, devem respeitar os princípios que garantem o equilíbrio das relações entre os membros da sociedade internacional (RIDRUEJO, 1996).

Assim, a noção de soberania, em termos atuais, visa a integração internacional e, ao limitar a esfera da jurisdição doméstica de cada Estado, amplia as possibilidades de colaboração intergovernamental, fortificada por um processo decisório coletivo. Esse agrupamento de Estados associados ao aceitar a limitação do poder soberano pela acentuada interdependência política e econômica entre as nações, reduz a incidência de conflitos regionais.

Verifica-se, nesse caso, o exercício do que se pode chamar de uma soberania coletiva, na qual os Estados-membros limitam seus próprios direitos soberanos, transferindo-os para instituições comunitárias sobre as quais não detêm controle direto, dessa forma, todos se conservam em patamar de igualdade, com liberdade na escolha de regimes de governo e formas de Estado, respeito mútuo à integridade territorial $\mathrm{e}$ independência política. 
A Carta das Nações estabelece a forma pacifica para a solução dos conflitos que eventualmente surgirem no cenário internacional, em respeito das normas de convivência pacífica e necessária a manutenção da ordem social, tendo em vista o poder devastador das guerras e seus reflexos sociais e ambientais. A força bélica ou econômica deve ser expurgada do meio internacional como forma de solução dos conflitos, uma vez que o conflito de entes soberanos poderá resultar efeitos catastróficos, tanto em termos políticos quanto sociais. $O$ uso dessas formas para a resolução de impasses internacionais enfraquece o Direito Internacional que carece de um poder sancionador, aplicador de penas aos infratores das normas de convivência, pois como tratamos de ordens soberanas, a única forma de submissão à jurisdição é por via da aquiescência a ela em um tratado ou acordo internacional.

Os paises por estarem na relação de igualdade soberana, onde cada soberania cede um pouco de seu absolutismo em prol da vida em uma sociedade internacional globalizada, devem pautar-se no trato com os demais, no sentido da não-intervenção, onde nenhum Estado ou grupo de Estados poderá intervir direta ou indiretamente nos assuntos internos ou externos de qualquer outro ${ }^{124}$. Dentro desse conceito é absolutamente contestável a intervenção bélica ou econômica, os chamados "embargos econômicos" e "intervenções bélicas ou brancas" existentes no mundo afora e comandadas na maioria pelos Estados Unidos e seus aliados. $O$ princípio da não intervenção supõe o direito de todo Estado soberano de conduzir seus assuntos sem ingerência exterior. A existência do princípio da não intervenção na opinio iuris dos Estados se apóia em uma prática importante e bem aceita. De outra parte, este princípio é um corolário do princípio da igualdade soberana dos Estados, pois tem seu fundamento lógico na organização da sociedade dentro dos princípios da igualdade soberana e da manutenção da paz no globo (RIDRUEJO, 1996).

O Brasil sempre procurou meios pacificos para resolver seus problemas ou questões de caráter internacional.

${ }_{124}$ Declaração de Princípios de Direito Internacional da ONU - Organização das Naçð̃es Unidas. 
Importante acontecimento na história das relações internacionais brasileiras ocorreu na Segunda Conferância da Paz, reunida em 1907, em Haia, na qual, sob as instruções do Barão do Rio Branco ${ }^{125}$, o delegado brasileiro Conselheiro Rui Barbosa defendeu a adoção obrigatória do arbitramento nos conflitos internacionais e a participação de todas as nações, em inteira igualdade, na Corte de Arbitramento. Naquela memorável oportunidade, o Brasil fixava, perante o mundo, sua posição face às questões internacionais e proclamava que o direito subjugador da força jamais devia prevalecer sobre o direito. Posteriormente, com a criação da ONU - Organização das Nações Unidas, depois da Segunda Grande Guerra, o Brasil, como um dos paises que a integram, passou a ter participação direta na solução dos problemas internacionais ${ }^{126}$. Por sua tradição histórica, o Brasil é uma nação anticolonialista; pelas lutas do seu passado, defende sua liberdade e respeita a liberdade das outras nações; acredita na democracia como força universal e no direito como a força que faz sobreviver a democracia para a felicidade dos povos e concórdia do mundo, por ser um país de tradição pacifista, mantém essa posição face ao mundo, o que faz com que ele seja também respeitado na ordem (BANDECCHI, 1970).

A Constituição Brasileira assegura o exercicio dos direitos sociais e individuais, a liberdade, a segurança, o bem-estar, o desenvolvimento, a igualdade $\mathrm{e}$ a justiça como valores supremos de uma sociedade fraterna, pluralista e sem preconceitos, fundada na harmonia social e comprometida, na ordem interna e internacional, com a solução pacífica das controvérsias. Constituindo-se em objetivos fundamentais da República Federativa do Brasil: a construção de uma sociedade livre, justa e solidária; a garantia do desenvolvimento nacional; a erradicação da pobreza e da marginalização e a redução das desigualdades sociais e regionais; a promoção do bem de todos, sem preconceitos de origem, raça, sexo, cor, idade e quaisquer outras formas de discriminação.

\footnotetext{
${ }^{125}$ O Baråo do Rio Branco, Ministro das Relaçðes Exteriores, marcou com sua presença no Itamarati a mais bela fase da diplomacia brasileira, pois atento à tradição nacional a consolidou perante o mundo, traçando normas tão nobres e seguras, que servem de orientação a quantos de boa vontade e patriotismo quiserem seguir aquela trilha modelar e luminosa que é sua obra, no que tange à política exterior do nosso pais.

${ }_{126}$ É uma iniciativa brasileira a integração econômica, política, social e cultural dos povos da América Latina, visando à formação de uma comunidade latino-americana de naçōes (artigo $4^{\circ}$, parágrafo único, da Constituiçăo Federal de 05 de outubro de 1988).
} 
Consagra, para tanto, os seguintes Principios Fundamentais: a soberania; a cidadania; a dignidade da pessoa humana; os valores sociais do trabalho e da livre iniciativa; e o pluralismo político ${ }^{127}$.

A República Federativa do Brasil rege-se nas suas relações internacionais pelos seguintes princípios: independência nacional; prevalência dos direitos humanos; autodeterminação dos povos; não-intervenção; igualdade entre os Estados; defesa da paz; solução pacífica dos conflitos; repúdio ao terrorismo e ao racismo; cooperação entre os povos para o progresso da humanidade; e a concessão de asilo político $^{128}$.

No que respeita aos princípios da autodeterminação dos povos e da nãointervenção, a Declaração da Organização das Nações Unidas, em seu artigo 10, dispõe:

1. O direito ao desenvolvimento é um inalienável direito humano, em virtude do qual toda pessoa humana e todos os povos têm reconhecido seu direito de participar do desenvolvimento econômico, social, cultural e político, a ele contribuir e dele desfrutar; e no qual todos os direitos humanos e liberdades fundamentais possam ser plenamente realizados.

2. O direito humano ao desenvolvimento também implica a plena realização do direito dos povos a autodeterminação, que inclui o exercício de seu direito inalienável de soberania plena sobre todas as suas riquezas e recursos naturais.

Entretanto, esses princípios não devem ser analisados individualmente, mas no contexto do ordenamento jurídico como um todo, em especial no que respeita ao meio ambiente que constitue, como já visto, um direito para fruição humana coletiva.

\footnotetext{
${ }^{127}$ Artigos $1^{\circ}$ e $3^{\circ}$ da Constituição Federal de 05 de outubro de 1988.

${ }^{128}$ Artigo $4^{\circ}$ da Constituição Federal de 05 de outubro de 1988.
} 
A colisão entre direitos fundamentais, dentre os quais se incluem as normas internacionais de direito ambiental, não é solucionada pela exclusão de um em proveito do outro, mas sim pela ponderação axiológica, harmonização prática ou solução de compromisso. A despeito de haver (aparente) contrariedade entre os princípios, eles não se contradizem, pois a contradição não admite meio-termo (por exemplo: quente e não quente), daí porque no caso de contradição há que se excluir, necessariamente, um pólo quando se reconhece o outro, em respeito ao princípio lógico da não-contradição, no qual uma coisa não pode ser e não ser ao mesmo tempo e sob o mesmo aspecto. A contrariedade, por sua vez, admite meio-termo, razão pela qual se pode encontrar uma solução dialética para ela (por exemplo: entre o quente e o frio, há a possibilidade do morno). Os princípios não podem entrar em contradição porque não qualificam juridicamente uma conduta como lícita ou ilícita, mas apenas consagram um valor (MAGALHÃES FILHO, 2002).

Dessa forma, outros princípios aplicáveis ao direito ambiental internacional devem ser sopesados e ponderados: principio do ambiente ecologicamente equilibrado como direito fundamental da pessoa humana, princípio da natureza pública da proteção ambiental, princípio da prevenção, princípio da responsabilidade, princípio do desenvolvimento sustentável, princípio da precaução, princípio do poluidor-pagador, princípio do controle do poluidor pelo poder público, princípio da consideração da variável ambiental no processo decisório de políticas de desenvolvimento, princípio da participação comunitária, princípio da cooperação entre os povos.

No Brasil, esses princípios de ordem ambiental, estão contidos no artigo 225 da Constituição Federal:

"Todos têm direito ao meio ambiente ecologicamente equilibrado, bem de uso comum do povo e essencial à sadia qualidade de vida, impondo-se ao Poder Público e à coletividade o dever de defendê-lo e preservá- lo para as presentes e futuras gerações." 
O princípio da cooperação entre os povos ${ }^{129}$ é por demais importante na esfera ambiental, posto que uma das principais áreas de interdependência entre as nações é a relacionada à proteção do ambiente, uma vez que as agressões a ele infligidas não se circunscrevem aos limites territoriais de um único país, espraiandose também a outros vizinhos ou ao ambiente global do planeta. $\mathrm{O}$ meio ambiente não conhece fronteiras, mas a gestão dos recursos naturais deve ser objeto de tratados e acordos bilaterais e multilaterais (MILARÉ, 2000).

A questão da dimensão transfronteiriça e global das atividades degradadoras exercidas no âmbito das jurisdições nacionais foi tema da Conferência Mundial sobre o Meio Ambiente, ocorrida em Estocolmo, em 1972, estando consignada na Declaração sobre o Ambiente Humano, resultante do evento; bem como na Conferência das Nações Unidas sobre o Meio Ambiente e o Desenvolvimento, conhecida como ECO-92, realizada no Rio de Janeiro, em 1992, cujos documentos resultantes, Declaração do Rio e Agenda 21, também revelam a importância do inter-relacionamento entre países no contexto do binômio desenvolvimento/meio ambiente (MILARÉ, 2000).

Mas, na medida em que se impõe o princípio da cooperação entre os $\operatorname{povos}^{130}$ não se renuncia à soberania ou ao principio da autodeterminação dos povos $^{131}$, ao contrário, os dois principios coexistem e se complementam:

"Os Estados, de conformidade com a Carta das Nações Unidas e os princípios da lei internacional, têm o dever soberano de explorar seus próprios recursos segundo suas próprias políticas ambientais e de desenvolvimento, e a responsabilidade de velar para que as atividades realizadas dentro de sua jurisdição ou sob seu controle não causem danos ao meio ambiente de outros Estados ou de zonas que estejam fora dos limites da jurisdição nacional."

\footnotetext{
129 Constituição Federal, artigo $4^{\circ}$, inciso IX. O Brasil estabelece como principio nas suas relaçð̃es internacionais, entre outros, a: cooperação entre os povos para o progresso da humanidade.

130 Princípio 2 da Declaração do Rio.

${ }^{131}$ Corollaries of the principle of self-determination of nations: na international system of protection of national minorities and a system of mandates in respect of some dependent territories (VUKAS, 2002).
} 
Diz-se, assim, que os Estados são partes indissoluvelmente integradas num mundo só e único, não mais independente, mas cada vez mais dependentes e a conclusão de convenções e tratados internacionais diminui-lhes, cada vez mais, 0 grau de autonomia ou soberania, permitindo a construção de um sistema jurídico que transcende o da órbita interna de cada Estado (RANGEL, 1993). Essa é a razão pela qual se afirma que a soberania do Estado já não é mais absoluta, mas relativa, uma vez que se encontra limitada pela obrigação de respeitar todas as regras internacionais, sejam elas gerais ou especiais, que se lhe aplicam (STRENGER, 2002).

É fato incontroverso que a sustentabilidade global dependerá da realização de uma firme aliança entre os países, considerando que os recursos globais e comuns só podem ser controlados com base em propósitos e ações coletivas.

A Declaração de Canelas, dos presidentes dos países do Cone Sul, com vistas à Conferência das Nações Unidas sobre Meio Ambiente e Desenvolvimento, publicada pelo Estado de São Paulo (caderno Cidades), em 21 de fevereiro de $1992^{132}$, subscrita pelos signatários do Tratado de Assunção e, também, pelo Chile, ressalta a importância de se incluir nas transações comerciais, os custos ambientais causados nas etapas produtivas sem transferi-los às gerações futuras, especificando, entre outros aspectos, que:

a) para atingir plenamente seus objetivos, os programas ambientais multilaterais têm de definir adequadamente as responsabilidades, respeitar as soberanias naionais no quadro do Direito Internacional e tornar realidade uma interdependência que garanta beneficios eqüitativos às partes;

b) os recursos biológicos são inequivocadamente recursos naturais de cada país e, portanto, sobre eles é exercida a soberania nacional;

c) o aproveitamento econômico dos recursos florestais é um direito soberano dos Estados que pode e deve ser compatibilizado com aproteção do meio ambiente;

${ }^{132}$ Apud MACHADO, 1995. 
d) não deve nenhum Estado apresentar, como exceção, seu próprio direito interno para subtair-se às suas obrigações internacionais.

Ainda no âmbito do Mercosul, dispõe o artigo 40 do Protocolo de Ouro Preto, firmado em 17 de dezembro de $1994^{133}$ :

A fim de garantir a vigência simultânea nos Estados Partes das normas emanadas dos órgãos do Mercosul previstos no art $2^{\circ}$ deste Protocolo, deverá ser observado o seguinte procedimento:

I. uma vez aprovada a norma, os Estados Partes adotarão as medidas necessárias para a sua incorporação ao ordenamento jurídico nacional e comunicarão as mesmas à Secretaria Administrativa do Mercosul;

II. quando todos os Estados Partes tiverem informado sua incorporação aos respectivos ordenamentos jurídicos internos, as Secretaria Administrativa do Mercosul comunicará o fato a cada Estado Parte;

III. as normas entrarão em vigor simultaneamente nos Estados Partes 30 dias após a data da comunicação efetuada pela Secretaria Administrativa do Mercosul, nos termos do item anterior. Com esse objetivo, os Estados Partes, dentro do prazo acima, darão publicidade do inicio da vigência das referidas normas por intermédio de seus respectivos diários oficiais.

No Brasil, essa transposição da norma orieunda do mercosul para o direito interno não é automática, nem imediata e depende de alguns procedimentos suplementares:

a) verificar se a norma proposta é confrome à Constituição Federal;

b) verificar se a norma proposta acarreta encargos ou compromissos gravosos ao patrimônio nacional;

c) verificar se a matéria proposta já foi objeto de lei complementar ou ordinária no Brasil e se há conflito entre as mesmas;

\footnotetext{
${ }^{133}$ Ratificado pelo Congresso Nacional pelo Decreto Legislativo $\mathrm{n}^{\circ} 188$, de 15.12 .1995 , e promulgado pelo Decreto ${ }^{\circ} 1.901$, de 09.05.1996.
} 
d) verificar se a matéria proposta já foi objeto de decreto do Presidente da República e se não há conflito entre elas.

De qualquer modo, em que pese a necessidade de celeridade no processo de recepção interna das normas propostas pelos órgãos do Mercosul, não se admite no direito interno dos Estados Partes o alijamento dos seus organismos parlamentares, os quais poderão emitir recomentações, porém sem poder decisório na estrutura do Mercosul, e deverão adotar todas as medidas necessárias para assegurar, em seus respectivos territórios o cumprimento das normas emanadas pelos órgãos decisórios do Mercosul.

É essencial reconhecer que para a eficácia da norma internacional é também imprescindível o fortalecimento dos organismos internos na vigilância das atividades de seus respectivos Estados, exercendo as pressões necessárias para cumprimento dos acordos e tratados formalizados para proteção ambiental em âmbito global (PRESTRE,2000). E, não se pode olvidar que vários são os elementos dificultadores na viabilização dos mecanismos de proteção ambiental internacional, entre eles:

a) a grande diversidade demográfica de países muito extensos ${ }^{134}$;

b) a falta de acesso aos recursos financeiros e tecnológicos para implantação de sistemas produtivos menos poluidores, por parte dos países menos desenvolvidos;

c) o temor de países menos desenvolvidos de que os instrumentos de proteção ambiental sejam utilizados como barreiras às suas exportações $^{135}$.

\footnotetext{
${ }^{134}$ Os dados populacionais não são facilmente relacionáveis a regiōes ambientais e a hipótese mais adequada seria abordar as questð̌es em nível macro, deixando de considerar as entidades nacionais e definindo os grupos globais homogêneos em função da taxa de crescimento, as populaçðes e as interações ambientais (TORRES e COSTA, 2000).

${ }^{135}$ Temor esse justificado dos paises menos desenvolvidos em relação aos paises desenvolvidos, o que dificultaria, ainda mais, seu efetivo desenvolvimento econômico e social (BORN, coord., 2002).
} 
Nenhuma nação é auto-suficiente, tanto mais em matéria ambiental, como já visto anteriormente, necessária se faz uma aliança global na qual as nações aceitem seus limites e responsabilidades, entendendo que os principios e normas ambientais, sejam na esfera nacional ou internacional, se inter-relacionam e se apoiam mutuamente (MILARÉ, 2000).

E a consciência da existência de problemas e interesses comuns à humanidade torna o mundo mais solidário, uma sociedade internacional mais justa, pacífica e fraternal, a partir da qual deixa-se de abordar as questões legais e passa-se a tratar da ética.

\subsection{A premência de uma postura ética para o efetivo desenvolvimento sustentável em âmbito internacional}

O conceito de desenvolvimento sustentável, mais que um conceito de desenvolvimento econômico, envolve noções de crescimento e atividades humanas em escalas temporais abrangentes, incluindo a noção de longo prazo ao propor que futuras gerações possam ter recursos similares ou melhores que os atuais.

$\mathrm{Na}$ implementação do conceito de desenvolvimento sustentável deve-se pressupor a convergência de objetivos das diversas políticas de desenvolvimento, não só de proteção ambientai, mas também sócio-cultural e econômico.

A busca e a conquista de um ponto de equilíbrio entre o desenvolvimento social, crescimento econômico e a utilização dos recursos naturais exigem um adequado planejamento territorial que tenha em conta os limites da sustentabilidade, o critério de desenvolvimento sustentável deve valer tanto o território nacional na sua totalidade, áreas urbanas e rurais, corno para a sociedade, para o povo, respeitadas as necessidades culturais e criativas do país (FIORILLO e RODRIGUES, 1997). 
O desenvolvimento sustentável é aquele que atende as necessidades de hoje sem comprometer as gerações futuras de também atenderem as suas necessidades. E, nesse ponto, as necessidades essenciais da população pobre do mundo devem ser atendidas com prioridade, sendo preciso, para tanto, rever os padrões de consumo que estão acima dos meios ecológicos do mundo atual.

Como as necessidades são determinadas social e culturalmente, necessário se faz a promoção de valores que mantenham os padrões de consumo dentro do limite das possibilidades ecológicas (CUNHA, 1996).

Assim, desenvolvimento sustentável significa a eqüitativa conjunção do equilíbrio ecológico, com a eficiência econômica e a justiça social (BAITELLO, 2000). Compreende-se, portanto, que o desenvolvimento não e um conceito independente e imutável, ao contrario, sua significância dependerá das circunstâncias sociais, culturais, econômicas, políticas e naturais que se apresentem quando do questionamento, considerados, então, o tempo e o espaço.

Nesse aspecto, exemplo importante a ser estudado é a questão da Amazônia. Paraíso dos naturalistas, foi a Amazônia chamada pelo escritor Raimundo Moraes, o que é correto, porque, na realidade, nenhum trecho do mundo foi mais objeto de curiosidade, como, também, nenhum apresentou os aspectos pitorescos, exóticos, novos, numa natureza de tanta exuberância tropical, a reclamar o estudo paciente, decidido, constante, dos naturalistas e dos demais homens da ciência (REIS, 1965).

Entretanto, nos dias atuais, ao lado da ecologia dos recursos naturais da Amazônia, há a ecologia humana, cujas necessidades não recebem qualquer destaque. É alarmante a quantidade de favelas existentes na chamada "capital verde do planeta", a pobreza e a miséria no paraíso ecológico a medrar no seio de um fantástico tesouro de recursos naturais. 
Assim como é rica em biodiversidade, a Amazônia dispõe de riqueza de matérias-primas para atender às necessidades de conforto material de sua população, mas a obtenção de uma ou de outra, sem degradar o ambiente ou os nichos ecológicos, tem um custo, o qual só pode ser suportado com a atividade de empresas legalmente organizadas em recursos humanos e tecnologias apropriadas. É a falta de conhecimento sobre a realidade da Amazônia que conduz a conclusões errôneas sobre a estratégia para a proteção da biodiversidade, esquecendo-se, a opinião pública internacional, da existência de comunidades de seres humanos que vivem nessa região, migrantes ou não, e retiram da floresta de maneira destrutiva $e$ irracional em relação aos recursos naturais. É ingênuo acreditar que basta criar unidades de conservação e áreas indígenas para proteger o bioma tropical. O que, na verdade, determinará o sentido do resultado da exploração é a capacidade (ou incapacidade) dos governos de orientar as ações humanas e econômicas para o desenvolvimento racional e para a sustentabilidade (BATALHA e HANAN, 1999).

Desta forma, a sustentabilidade que deve estar presente no desenvolvimento humano tem como característica fundamental à igualdade no aumento das oportunidades, capacidades, potencialidades e direitos de escolha dos indivíduos de forma a construir de maneira eqüitativa a melhor condição de vida, social, econômica, político, cultural e, principalmente, ambiental, entre os membros da presente e da futura geração.

O desenvolvimento sustentável significa qualidade muito mais que quantidade; a redução no uso de matérias-primas e produtos industrializados de consumo, aliada ao aumento da reutilização e na reciclagem, especialmente de embalagens, constituem a mola propulsora para o efetivo alcance do equilíbrio ecológico, principalmente quanto aos recursos naturais não renováveis, propondo uma visão tridimensional do desenvolvimento, no qual a eficiência econômica deve caminhar par e passo com a prudência ecológica e a busca por uma sociedade solidária e justa, pelo bem comum. 
$\mathrm{O}$ respeito aos limites impostos pela natureza constitui a tônica neste equilibrio socioeconômico e ecológico, objetivada pelo desenvolvimento sustentável.

A sustentabilidade requer ainda resultados sociais e não meramente administrativos, sendo o desenvolvimento sustentável um pressuposto lógico e natural da saúde coletiva, ou seja, tanto mais saudável será uma cidade, quanto mais sustentável for o seu desenvolvimento (COIMBRA 1999).

Em última análise, é o desenvolvimento sustentável, fundado numa eqüidade mundial e com objetivos verdadeiramente imbuidos do propósito maior de conservação da natureza, fator essencial para a sustentação da própria vida humana (MILARÉ, 2000).

Como é sabido, o homem que vive em sociedade está constantemente sujeito a uma serie de relações. Essas relações podem ser de amizade, de comércio, de moral, de direito.

Em nossos dias, os preceitos de natureza religiosa, de natureza moral e de natureza jurídica procedem de fontes diferentes e quando contrariados, provocam uma sanção contra quem os infringiu. Os preceitos religiosos têm origem extrahumana e, quando violados, provocam uma sanção, aplicada em outra vida. Os preceitos morais, cuja origem é discutida pelos filósofos, encontram uma sanção, quando contrariados, dentro da consciência humana. Os preceitos ou regras juridicas procedem do poder soberano do Estado, que é a expressão de uma coletividade, quando quebrados, rompe-se o equilíbrio jurídico da sociedade, o ofendido recorre aos tribunais buscando a condenação de quem o prejudicou.

É muito interessante a variedade de morais no tempo: segundo Nietzsche, “aquilo que numa época parece mau, é quase sempre um restolho daquilo que na precedente era considerado bom - o atavismo de um ideal já envelhecido" ${ }^{136}$.

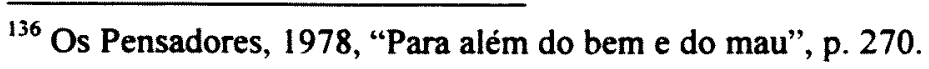


As doutrinas éticas fundamentais nascem e se desenvolvem em diferentes épocas e sociedades como respostas aos problemas básicos apresentados pelas relações entre os homens e em particular pelo seu comportamento moral efetivo. Por isto, existe uma estreita vinculação entre os conceitos morais e a realidade humana, social, sujeita historicamente a mudança (VASQUEZ, 1992).

MORAL, do latim mos (singular), e mores (plural), significa costumes. É o conjunto de regras de conduta assumidas pelos indivíduos de um grupo social com a finalidade de organizar as relações interpessoais segundo os valores do bem e do mal. Valor, por sua vez, é a relação de não indiferença entre o homem e os elementos com que se defronta: os valores indicam as expectativas e aspirações que caracterizam o homem em seu esforço de transcender-se a si mesmo e a sua situação histórica. A valoração é o próprio esforço do homem em transformar o que é naquilo que deve ser. E a área da filosofia que estuda os valores em geral, em especial a dos valores morais é chamada de axiologia.

ÉTICA (ou filosofia moral) é a parte da filosofia que se ocupa com a reflexão sobre as noções e princípios que fundamentam a vida moral. Ethos (do grego): modo de ser, caráter. É a teoria sobre a prática moral, a reflexão teórica que analisa e critica ou legitima os fundamentos e princípios que regem um determinado sistema moral. A ética surge quando surgem questionamentos sobre a validade de determinados valores ou costumes, para fundamentar teoricamente estes valores vividos de uma forma prática e, para aqueles que não concordam, para criticá-los. A experiência ética fundamental é a experiência de "estranhamento" frente à realidade, de sentir-se estranho diante do modo como funciona a sociedade, ou até mesmo em relação ao modo de ser e de agir de outrem: é a descoberta da diferença entre o que é e o que deveria ser (SUNG e SILVA, 1998).

Nos últimos anos, a questão ambiental vem se mostrando cada vez mais dependente de uma nova postura moral do ser humano, de uma nova ética no pensar e no agir. 
A realidade ambiental mutante, dinâmica, em constante movimento, exige, dos individuos de per si e da sociedade como um todo, novas normas de condutas para com o meio e com os demais seres que interagem com a espécie homem.

Assim, diante do fenômeno ambiental, não se pode pensar num discurso ético individualista; não se deve pensar simplesmente em relação ao agir de outro ser humano, deve-se assumir coletivamente a responsabilidade moral, por meio de uma "macroética", na qual, além da responsabilidade moral de cada um em face do seu próximo, ter-se-ia, também, a responsabilidade (organizada) da humanidade ante os efeitos principais e colaterais de suas ações coletivas em medida planetária. Dentro deste contexto espera-se a implantação de uma gestão ambiental em um contexto global, já que o meio ambiente não encontra limites territoriais e de soberania - a solidariedade ambiental e o princípio da participação e cooperação ambiental devem ser impulsionados sob a égide da ética ambienatal como a ética da vida humana e não humana, atual e das próximas gerações (RODRIGUES, 2002).

É necessária uma nova experiência ética para que possamos nos adequar as novas imposições da natureza para sua permanência, em especial no que diz respeito às interferências do homem no mundo natural: "... afinal, que e o homem dentro da natureza? Nada em relação ao infinito; tudo em relação ao nada; um ponto intermediário entre tudo e nada. Infinitamente incapaz de compreender os extremos, tanto o fim das coisas como os seus principios permanecem ocultos num segredo impenetrável, e é-lhe igualmente impossivel ver o nada de onde saiu e a infinito que a envolve" (PASCAL, appud SOUZA, 1995, p. 21).

Cabe ao próprio homem estabelecer essas novas regras de comportamento, devendo, para tanto, considerar que todos os seres vivos têm valor em si mesmo e em seu contexto maior de interação com o seu meio, independentemente de apresentar um valor (qualquer que seja) para o ser humano. 
A diversidade e a riqueza das formas de vida contribuem, direta e indiretamente, para a concretização desses valores, não tendo o homem o direito de reduzir tais riquezas ou diversidades, senão para satisfação de suas necessidades vitais, dentro do conceito de luta pela sobrevivência da espécie.

O homem, como todo ser vivo, age sobre a natureza com a finalidade de sobreviver enquanto espécie. Difere, porém, dos demais seres vivos pela consciência que tem de que está transformando a natureza para adaptá-la as suas necessidades, ou seja, sua atuação na natureza não e apenas resultado de um código genético biologicamente determinado, mas ocorre de forma intencional e planejada (SOUZA, 1995). E é exatamente em razão dessa consciência que compete ao homem, enquanto espécie, e só a ele, a responsabilidade também peia sobrevivência das demais espécies do Planeta.

A ação antrópica sobre o meio ambiente como um todo, no ar, no solo, na água, interferindo, direta ou indiretamente, na sobrevivência das demais espécies do globo, deixando rastros de incerteza quanto à possibilidade de vida futura, com o crescente desaparecimento dos recursos naturais que, também, de forma direta e indireta, permitirão a permanência do homem na Terra.

A nova postura moral que se espera do homem frente ao seu meio é a consciência da vida em todas as suas formas e sua exclusiva responsabilidade sobre ela. Essa e a nova experiencia ética que se faz necessária: o homem, seu ambiente e os demais seres que nele habitam. Mas, como esperar que filhos da miséria e da fome possam se engajar nesta luta pela preservação de recursos naturais nãorenováveis para as futuras gerações? Como falar em desenvolvimento sustentável, se uma enorme parcela da população mundial não tem como se desenvolver e, muitas vezes, nem mesmo como sustentar sua sobrevivência ou a de seus filhos? É necessário o atendimento emergencial das condições sociais desfavorecidas em âmbito mundial, posto que não há fronteiras para a degradação ambiental e o prejuízo é extensivo a todas as populações e não só àquelas desencadeadoras do evento danoso. 
Não há como exigir consciência ambiental se não se consegue extirpar a doença maior da humanidade que é a desigualdade social, a miséria, a fome. É, portanto, imperioso procurar uma postura que adote um meio termo, o que significa reconhecer a existência dos recursos naturais e a premência de sua utilização visando à sobrevivência não só humana, mas de toda a vida no globo terrestre. É ponto pacífico que a atividade tecnológica racional e planificada, preserva o equilibrio dinâmico do meio natural ou, pelo menos, minimiza os impactos decorrentes do processo evolutivo tecnológico (ROCHA, 1995).

$\mathrm{O}$ alto desenvolvimento dos países industrializados, chamados países ricos ou do primeiro mundo, custou muito caro para todo o planeta que hoje apresenta seqüelas irreversíveis. As conseqüências de uma industrialização semelhante pelos demais países do globo seriam insustentáveis. Por outro lado, não se pode estancar o desenvolvimento econômico e este sempre acarreta impactos ambientais, dessa forma e imperioso que se modifique os modelos de desenvolvimento e, nesse processo, a colaboração entre os povos é fundamental. E, nesse passo, a gestão ambiental global, com o estabelecimento de padrões globais para a preservação da qualidade da água dos rios, fonte de vida e de saúde, manancial de alimento para diversas espécies, é questão prioritária.

Fica difícil falar em preservar as baleias, quando o indivíduo tem, em casa, crianças com diarrẻia porque bebem água contaminada. Daí a importância do enfoque do ambiente total, que considera todos os seus aspectos (DIAS, 1998). Necessário se faz o reconhecimento da premência do estabelecimento de uma ética ambiental global - o bem-estar e a sobrevivência da humanidade depende do valor que as pessoas atribuam: ao respeito e consideração pelos outros, particularmente aos menos favorecidos; ao cuidado e proteção aos recursos da humanidade (em especial da água em sua qualidade e abundância); à promoção de ações que beneficiam a humanidade como um todo (um mesmo planeta, sem limites ou fronteiras para as ações de cooperação, assim como é para os eventos danosos ao meio ambiente) e melhorem a qualidade ambiental. 
O comportamento das pessoas em relação ao seu ambiente natural e artificial é a expressão clara de valores e atitudes, compreensão e habilidades que, se espera, caminhem em direção a uma relação harmônica e ética do homem com o seu meio ambiente ${ }^{137}$.

A humanidade deixou de constituir uma noção apenas biológica e deve ser plenamente reconhecida em sua inclusão indissociável na biosfera; a humanidade está enraizada em uma "pátria", a Terra - e a Terra é uma pátria em perigo; a humanidade tornou-se uma comunidade de destino e somente a consciência dessa comunidade pode conduzi-la a uma comunidade de vida, pois a humanidade é, sobretudo, uma noção ética que deve ser realizada por todos e em cada um, na busca do aprimoramento nas relações, integração e desenvolvimento mútuo dos indivíduos, das sociedades e das espécies, na busca da hominização na humanização, do acesso à cidadania terrena e de uma comunidade planetária verdadeiramente organizada (MORIN, 2000).

Nesse sentido, a lei ${ }^{138}$ não deve ser recebida como uma obrigação contratual e, muito menos, de efeito provisório. Ela deve ser entendida, sim, como preceito moral, fundamentada não na vontade dos governantes, mas baseada no próprio conceito de liberdade, segundo o qual a ninguém é dado o direito de usar predatoriamente o bem comum, ou comprometer a existência de bens naturais que serão indispensáveis às gerações futuras (BRANCO, 2002).

Nas palavras de ODUM (1983), quando o estudo da casa (Ecologia) e a administração da casa (Economia) puderem fundir-se, e quando a ética puder ser estendida para incluir o ambiente, além dos valores humanos, então poderemos realmente ser otimistas em relação ao futuro da humanidade.

\footnotetext{
${ }^{137}$ Premissas contidas no documento $n^{\circ} 8$ da série Educação Ambiental da UNESCO/1986, a partir das discussões originadas na Conferência Intergovernamental sobre Educação Ambiental promovida pela UNESCO-PNUMA, em Tbilisi, Geórgia, em 1977.

${ }_{38}$ Nesse contexto estão incluídos os tratados internacionais em matéria ambiental, os quais, uma vez assinados e recepcionados pelo pais, tornam-se leis cuja observância se faz obrigatória também internamente.
} 
Essa nova postura ética deve estar presente em todas as ações necessárias para a efetiva governabilidade global, pressupondo a existência de regras democráticas e cosmopolitas a fim de que os atores possam negociar seus diferentes interesses de forma progressiva, realista e racional, na procura do objetivo comum, compromissado com a dinâmica real do mundo contemporâneo (VIOLA, 2003).

No decurso do seu desenvolvimento, o homem sempre operou com a categoria de utilidade, sendo a utilidade uma qualidade capaz de garantir a sobrevivência e o desenvolvimento, uma vez que para ele a utilidade será tanto mais elevada quanto maior for o grau em que seu uso aumenta sua resistência como organismo e o conforto de sua existência, e quanto menor for o preço relativo que ele precisa pagar pelo preço dessa coisa no sistema de manutenção da vida. Mas, no aspecto ambiental, há a suplementação do princípio da utilidade, com o surgimento de valores que não levam em conta o consumo, mas a preservação, a raridade e a parcimônia (PUZATCHENKO, 1998).

O meio ambiente é mais do que a natureza, é também um produto cultural e um campo de ação econômica, política e social. E, de fato, não há como pensar no meio ambiente dissociado dos demais aspectos da sociedade.

Os riscos que se apresentam à humanidade, criados pela civilização, restituem ao homem a aventura de retomar seu destino e controlá-lo. O que ele antes fazia temendo aos deuses aos quais já não teme, com medo das pragas, que já controla, submetido ao desconhecido, que já conhece, agora o homem terá que fazer diante dos riscos que criou. Terá que enfrentar um deus maluco chamado homem, uma praga chamada poder científico e tecnológico e tentar desvendar um desconhecido chamado ele mesmo, seu sistema econômico, sua relação com a natureza, a essência de seu processo civilizatório (BUARQUE, 1990).

$\mathrm{E}$, assim, toda a atividade legiferante ou política, sobre qualquer tema ou obra deve levar em conta a preservação da vida e, principalmente, da sua qualidade. 
O mundo não é mais apenas, ou principalmente, uma coleção de estados nacionais, mais ou menos centrais e periféricos, arcaicos e modernos, agrários e industrializados, coloniais e associados, dependentes e independentes, ocidentais e orientais, reais e imaginários. As nações transformaram-se em espaços, territórios ou elos da sociedade global, hoje a chamada era planetária requer a associação de Estados-nações para encaminhamento de questões fundamentais para a sobrevivência do planeta, dentre as quais destacam-se as questões ambientais (LEONARDI, 1998).

Mas, a cidadania planetária, plena e crítica, impõe reformulações nom processo de conhecimento, exige a participação nos espaços sociais, a solidariedade, o senso de responsabilidade individual e coletiva, o respeito ao diverso e ao tradicional, ao global e ao local e, principalmente, o respeito à vida em todas as suas manifestações (LOUREIRO et al, 2002).

A água é dom de Deus e fonte de vida, patrimônio de todos os seres vivos, não apenas da humanidade, mas também os animais e os vegetais, portanto necessidade e direito de todos. Nenhum outro uso da água pode se sobrepor às leis básicas da vida. O Estado e todos as pessoas têm o dever de zelar para a sua preservação e conservação. Além de usos, a água tem dimensões, valores e significados que precisam ser respeitados, porque são referências fundamentais para muitos povos, entre eles, o valor biológico, o social, o simbólico e espiritual, o valor paisagístico e turístico, dimensão política e do poder, dimensão poética e artística, dimensão saúde, dimensão ecológica. ${ }^{139}$

\footnotetext{
139 Pela primeira vez na história humana, estamos percebendo a falta da água não como um fato localizado ou emergencial, mas como resultante de açð̄es humanas, colocando em risco a sua sobrevivência, a Campanha da Fraternidade quer ser alerta, ajudar na conjugação de esforços e de solidariedade entre as pessoas (Dom Agnelo, 2004). A Conferência Nacional dos Bispos do Brasil promove anualmente a Campanha da Fratemidade quando propð̌e revisão de um ponto de vida na busca de ação concreta para a promoção da fraternidade humana. O tema proposto para este ano é " $A$ Fraternidade e a Água e como lema Água, fonte de vida".
} 
"Laudato sie, mi Signore, per sor'acqua,

la quale é molto útile

et humileet pretiosa et casta."140

\section{CONCLUSÃo}

Verifica-se no modo de vida atual do homem, com a derrubada das últimas fronteiras da informação, um acentuado inter-relacionamento sócioeconômico e político dos países em âmbito global, conduzindo à unidade dos povos, sendo esse fator determinante na preservação da espécie humana e dos demais seres e elementos que compõem o meio ambiente.

Nesse passo, mudanças profundas têm ocorrido no ambiente, em seus aspectos fisico, econômico, político e cultural e no comportamento dos indivíduos e, por consequiência, na sociedade como um todo. Entretanto, tem-se a sensação de que ainda o homem age superficialmente em relação ao meio ambiente. Vê ele (homem) o ambiente como algo externo a si mesmo, com o qual ele (homem) interage em momentos isolados e voluntários, numa percepção equivocada de seu papel nas alterações ambientais vivenciadas direta ou indiretamente pela sociedade.

Com essa mesma postura encontram-se alguns Estados que assumem uma postura distante no que respeita à proteção ambiental, recusando-se a assinar tratados ou deixando de cumprir as normas internacionais da qual é signatário, atribuído às questões econômicas e politicas acima da preservação e conservação do meio ambiente.

\footnotetext{
140 "Louvado sejas, meu Senhor, pela irmã água, que é muito útil, humilde, preciosa e casta". (Cantico della Creature, San Francesco d'Assisi appud COIMBRA, 2002, p. 76).
} 
Sabe-se que em cada Estado do Globo há leis diversas para solução dos conflitos de interesses internos dos indivíduos que o compõe, havendo também normas específicas de proteção ambiental que regulam as atividades do homem, de acordo com as características e necessidades de cada região.

Entretanto, as questões ambientais muitas vezes não se encontram restritas a um determinado território, não afetam somente determinado povo, mas sim várias localidades no entorno e, não raras vezes, interferem diretamente em todo o Planeta, atravessando fronteiras, em especial àquelas delimitadas por cursos d'água.

A lei é a representação externa do dever ser em sociedade, é a exteriorização dos valores subjetivos a serem respeitados por todos os destinatários daquela norma. E são exatamente os valores subjetivos de cada ser humano e da sociedade como um todo o caminho para a solução dos conflitos de ordem ambiental.

Cada Estado tem sua soberania, que é o poder máximo de que está dotado o Estado para fazer valer suas decisões e sua autoridade dentro do seu território. É cada Estado também responsável pela utilização dos recursos naturais existentes em seu território e pelo desenvolvimento social e econômico de seu povo.

É ponto pacífico que o meio ambiente é elemento essencial para o desenvolvimento integral do homem, no qual está inserido o conceito de saúde, e desastrosas serão as conseqüências que poderão colocar em risco a sobrevivência da espécie humana, caso o equilíbrio ecológico não seja uma constante. Tanto mais considerando a água que, embora seja fonte primordial da vida, sendo múltiplos seus usos no abastecimento, dessedentação de animais, piscicultura, irrigação, além de seu uso mais nobre que é a potabilidade, é fator também de inúmeros agravos à saúde como condutora de más condições ambientais decorrentes da poluição das águas. 
Para utilização dos benefícios da água, em sua plenitude e sem os riscos à saúde, esta deverá apresentar determinados padrões mínimos de qualidade, os quais, por sua vez, devem ser objeto não só de normatização interna, como também internacional, com monitoramento constante e direto de organismos governamentais e não-governamentais.

É mais que sabido que a poluição ambiental, em especial das águas, é um problema de saúde pública e o saneamento do meio um dos objetivos desta. Assim, o controle da poluição dos cursos d'água nas regiões transfronteiriças é de real importância e os instrumentos para sua efetiva observância questão de relevante interesse, enquanto problema emergencial de saúde pública, uma vez que a contaminação da água é fonte de agravos maiores que colocam em risco não só a qualidade de vida da população, mas a própria sobrevivência desta.

É fato incontroverso que a questão ambiental não tem fronteira: a poluição ambiental causada em determinada parte do globo poderá resultar problemas ecológicos, econômicos e de saúde a outra, ou outras regiões, ou, até mesmo, para a totalidade do Planeta.

Dessa forma, não se pode admitir um controle setorial, em especial nas regiões de fronteira, especificamente quando se trata de cursos d'água, nos quais se torna mais difícil limitar, em termos espaciais, a poluição àquele país que não observou os padrões de qualidade existentes.

Por outro lado, não adianta a declaração de tratados internacionais se os países se recusam a participar como signatários, ou se o fazem, não se pode exigir o cumprimento pela ausência do elemento coativo em razão da soberania de cada Estado. 
A exigibilidade do cumprimento de um tratado internacional só será viável após a recepção da norma internacional pelo direito interno, o que, como visto, não ocorre com a necessária celeridade, nem tampouco tem o devido monitoramento quanto à sua efetiva observância.

Ao lado dos orgãos estatais, as organizações não-governamentais cumprem papel fundamental no acompanhamento das atividades potencialmente poluidoras, como elemento de pressão para a fiscalização e a aplicação das penalidades previstas no caso de desobediência às leis ambientais.

Paralelamente a essas ações, deve se estar atento às novas tecnologias desenvolvidas na área ambiental, sendo o meio ambiente dinâmico e alvo de constantes alterações fruto da intervenção antrópica e também da própria ação da natureza, não se pode conceber um direito ambiental internacional estático, ao contrário, dem os padrões de qualidade sofrer constantes atualizações frente às novas descobertas da ciência e também às modificações sofridas sejam elas naturais ou não. Tanto mais no que se refere aos recursos naturais finitos, dentre eles a água, cuja escassez já é motivo de conflito entre populações, devendo, também, ser objeto de monitoramento, para fins de prevenção, a concentração demográfica em áreas territorias consideradas em função de suas características naturais e não somente em relação ao país ou região política a qual estejam vinculadas.

As intensas concentrações humanas nas regiões urbanizadas, com fortes pressões nos sistemas hídricos originando problemas de escassez de água, constituem atualmente um fenômeno mundial. Sendo o binômio escassez - utilidade um dos mais importantes conceitos quando se trata da valorização econômica dos bens utilizados pelo homem, desse modo se à demanda humana por água potável for associada a demanda industrial, pode-se chegar a situações bastante delicadas em vista dos altos volumes utilizados. 
Surge dai, como exemplo de novas tecnologias, a importante proposta do reúso da água, a partir do tratamento adequado de esgotos, com o intuito de aperfeiçoar e melhorar os sistemas de gestão de recursos hídricos e saneamento ambiental (MANCUSO e SANTOS, 2002) ${ }^{141}$.

Mas não se pode olvidar que a aplicação dos princípios do desenvolvimento sustentável e o efetivo controle da qualidade da água como garantia da saúde coletiva, sem prejuizo do princípio da soberania dos povos e de sua autodeterminação para o livre desenvolvimento social e econômico, seja o Estado signatário ou não dos tratados internacionais ambientais, são hoje muito mais uma questão de valor moral.

O elemento coativo é crucial para a efetiva observância da norma, pois é o temor da pena pela sua desobediência que faz com que ela seja obedecida. No entanto, a norma ambiental internacional não é dotada de sanção, uma vez que a soberania do Estado não pode ser violada. O limite das normas internacionais ambientais é dado pelo próprio Estado não só quando da recepção destas, mas também na medida em que estabelece mecanismos de fiscalização e punição internas para que sejam respeitadas.

As leis são expressões morais cujo valor mereceu maior atenção da sociedade, são também chamadas de normas éticas, pois antes da sanção recebem a reprovação social. No que respeita às leis ambientais esse valor moral extrapola, pois como únicos seres racionais, têm os homens papel fundamental na busca pelo equilíbrio e da sobrevivência das demais espécies do Planeta. Hoje se busca a humanização da humanidade e esse é o maior desafio ambiental.

\footnotetext{
141 Reúso de Água é o aproveitamento de águas previamente utilizadas, uma ou mais vezes, em alguma atividade humana, para suprir as necessidades de outros usos benéficos, inclusive o original. Pode ser direto ou indireto, bem como decorrer de açð̃es planejadas ou não planejadas.
} 
Olhar o meio ambiente não como quem está diante de uma vitrine, mas enxergando que o meio ambiente está no homem e o homem é elemento que o compõe, é fator primordial na conscientização da responsabilidade do ser humano sobre a preservação ambiental, as demais espécies do Planeta e os recursos naturais não-renováveis, em especial a água.

O ambiente não pode ser visto de modo seccionado, pois não há fronteiras reais - ele é um todo harmônico e interdependente, no qual homem deve espelhar sua conduta hoje também global.

$O$ ambiente deve ser cuidado, como se cuida de um bem raro, como se cuida do seu próprio jardim. Tomar para si a responsabilidade é dever de cada um e de todos, esse é o princípio moral desejado para a verdadeira sustentabilidade ambiental, pois não pode haver progresso econômico e social durável para qualquer país se a questão ambiental não for enfocada com o devido respeito, como elemento essencial para a permanência da vida na Terra. 


\section{REFERÊNCIAS BIBLIOGRÁFICAS}

Ab'Sáber AN. A ecologia e o novo padrão de desenvolvimento no Brasil. São Paulo: Nobel, 1992.

Agnelo GM. Campanha da fraternidade. Salvador: CNBB; 2004.

Accioly H. Manual de direito internacional público. São Paulo: Saraiva; 1986.

Accioly H. Silva GEN. Manual de direito internacional público. São Paulo: Saraiva; 2002.

Aristóteles. Poética. Os Pensadores. São Paulo: Abril; 1973.

Baitello JB. Ecologia geral. São Paulo: Secretaria do Meio Ambiente; 2000 [material apostilado: I worshop sobre meio ambiente para jornalistas realizado em Santos].

Bandecchi B. História econômica e administrativa do Brasil. São Paulo: Didática Irradiante; 1970.

Baptista LO. Inserção das normas do Mercosul no direito brasileiro. In $\mathrm{O}$ direito internacional no terceiro milênio, Luiz Olavo Baptista e José Roberto Franco da Fonseca, coordenadores. São Paulo: LTR; 2002. 
Batalha BHL. Subsídios à reflexão ambiental. São Paulo: Universidade de São Paulo. Faculdade de Saúde Pública. Departamento de Saúde Ambiental; 1996.

Batalha BHL. Hanan SA. Amazônia: contradições no paraíso ecológico. São Paulo: Cultura Editores Associados; 1999.

Bertolli Filho C. História da saúde pública no Brasil. São Paulo: Ática; 1999.

Bobbio N. Teoria do ordenamento jurídico. Brasília: Editora Universidade de Brasília; 1997.

Born RH. O processo internacional da Rio-92, seus resultados e produtos (Agenda 21 e Convenções de Clima e de Biodiversidade) e a participação de atores não governamentais: novos valores e instrumentos para a gestão do desenvolvimento humano. São Paulo; 1998 [Tese de Doutorado Faculdade de Saúde Pública da USP].

Born RH. Diálogos entre as esferas global e local (Contribuições de organizações não-governamentais e movimentos sociais brasileiros para a sustentabilidade, eqüidade e democracia planetária). São Paulo: Peirópolis; 2002.

Branco SM. Meio ambiente: uma questão moral. São Paulo: OAK; 2002.

Branco SM. Hidrobiologia aplicada à engenharia sanitária. São Paulo: CETESB; 1986.

Branco SM, Rocha AA. Ecologia: educação ambiental. São Paulo: CETESB;1980. 
Branco SM, Rocha AA. Poluição, proteção e usos múltiplos de represas. São Paulo: CETESB; 1977.

Branco SM. Poluição - A morte de nossos rios. Rio de Janeiro: Ao Livro Técnico; 1972.

Buarque C. A desordem do progresso. São Paulo: Paz e Terra; 1990.

Canotilho JJG. Direito Constitucional. Coimbra: Almedina; 1993.

Casella PB. Reconhecimento de Estado e Governo do direito internacional contemporâneo. In $\mathrm{O}$ direito internacional no terceiro milênio, Luiz Olavo Baptista e José Roberto Franco da Fonseca, coordenadores. São Paulo: LTR; 2002.

Coimbra JAA. O outro lado do meio ambiente. São Paulo: Millenium; 2002.

Coimbra JAA. Cidades saudáveis e cidades sustentáveis: teorias e práticas. São Paulo: Faculdade de Saúde Pública da Universidade de São Paulo; 1999 [material apostilado].

Coralina C. Poemas dos becos de Goiás e estórias mais. São Paulo: Global; 1991.

Cotrim GV. Direito e legislação: introdução ao direito. São Paulo: Saraiva; 1992.

Coulanges F. A cidade antiga. São Paulo: Martins Fontes; 1998.

Cretella Júnior J. Direito administrativo comparado. São Paulo: Bushatsky; 1972. 
Cunha IA. São Sebastião: Política ambiental na costa norte de São Paulo - sustentabilidade e poder local. São Paulo; 1996 [Tese de Doutorado Faculdade de Saúde Pública da USP].

Dallari D.A. Elementos da teoria geral do Estado. São Paulo: Saraiva; 1982.

David R. Os grandes sistemas do direito contemporâneo. São Paulo: Martins Fontes; 1998.

Deebeis TD. Elementos de direito ambiental brasileiro. São Paulo: Universitária de Direito; 1999.

Dias GF. Educação ambiental: princípios e práticas. São Paulo: Gaia; 1998.

Diniz MH. Dicionário Jurídico. São Paulo:Saraiva; 1998.

Donaire D. Gestão ambiental na empresa. São Paulo: Atlas; 1999.

Dorado AJ. Gestão ambiental na fronteira agrícola da Amazônia. São Paulo; 1998 [Tese de Doutorado - Faculdade de Saúde Pública da USP].

Faria WR. Unidade do direito e uniformidade na interpretação e aplicação das normas do Mercosul. In $\mathrm{O}$ direito internacional no terceiro milênio, Luiz Olavo Baptista e José Roberto Franco da Fonseca, coordenadores. São Paulo: LTR; 2002.

Fiorillo CAP, Rodrigues MA. Manual de direito ambiental e legislação aplicável. São Paulo: Max Limonad; 1997. 
Fiorillo CAP. Curso de direito ambiental brasileiro. São Paulo: Saraiva; 2003.

Fonseca JRF. Estrutura e funções da Corte Internacional de Justiça. In $\mathrm{O}$ direito internacional no terceiro milênio, Luiz Olavo Baptista e José Roberto Franco da Fonseca, coordenadores. São Paulo: LTR; 2002.

Forattini OP. Epidemiologia geral. São Paulo: Artes Medicas; 1996.

Forattini OP. Ecologia, epidemiologia e sociedade. São Paulo: Artes Medicas; 1992.

Freitas VP. A constituição federal e a efetividade das normas ambientais. São Paulo: RT; 2001.

Garcia Junior AA. O direito ambiental no Mercosul. Notícias Forenses. Rio de Janeiro: Forense; 1997.

Gaarder J. O mundo de Sofia. São Paulo: Companhia das Letras; 1995.

Grinover AP. As garantias processuais na cooperação internacional em matéria penal. In $\mathrm{O}$ direito internacional no terceiro milênio, Luiz Olavo Baptista e José Roberto Franco da Fonseca, coordenadores. São Paulo: LTR; 2002.

Grupenmacher BT. Tratados internacionais em matéria tributária e ordem interna. São Paulo: Dialética; 1999.

Gualazzi ELB. Confederalização Pan-Americana. In $\mathrm{O}$ direito internacional no terceiro milênio, Luiz Olavo Baptista e José Roberto Franco da Fonseca, coordenadores. São Paulo: LTR; 2002. 
Guardia E. Reflexiones jurídico-diplomáticas sobre los grandes tratados codificadores del derecho internacional. In $\mathrm{O}$ direito internacional no terceiro milênio, Luiz Olavo Baptista e José Roberto Franco da Fonseca, coordenadores. São Paulo: LTR; 2002.

Kelsen $H$. General theory of law and state. Cambridge: Harvard University; 1945.

Kelsen H. Princípios de derecho internacional público. Tradução: Hugo Caminos e E.C. Hermida. Buenos Aires: Editora Inglesa; 1965.

Kiss A. Direito internacional do ambiente. Lisboa: Centro de Estudos Judiciários; 1996.

Leavell HR, Clark EG. Medicina preventiva. São Paulo: McGraw-Hill do Brasil; 1976.

Leonardi MLA. A sociedade global e a questão ambiental. In Desenvolvimento e natureza: estudos para uma sociedade sustentável. Clóvis Cavalcanti (organizador). São Paulo: Cortez; 1998.

Loureiro CFB. Layrargues PP. Castro RS. [Organizadores]. Sociedade e meio ambiente: a educação ambiental em debate. São Paulo: Cortez; 2002.

Machado PAL. Direito ambiental brasileiro. São Paulo: Malheiros; 1995.

Magalhães JC. O Supremo Tribunal Federal e o direito internacional: uma análise crítica. Porto Alegre: Livraria do Advogado; 2000.

Magalhães Filho GB. Hermenêutica jurídica clássica. Belo Horizonte: Mandamentos; 2002. 
Magano OB. A Convenção $n^{\circ} 158$ da OIT. In O direito internacional no terceiro milênio, Luiz Olavo Baptista e José Roberto Franco da Fonseca, coordenadores. São Paulo: LTR; 2002.

Mancuso PCS. Santos HF. Reúso de água. São Paulo: Universidade de São Paulo. Faculdade de Saúde Pública. Departamento de Saúde Ambiental. Associação Brasileira de Engenharia Sanitária e Ambiental (ABES); 2002.

Martins G, Boranga JA. Passando a história a limpo. São Paulo: 2001 [Artigo publicado na Revista "Ser Médico" do Conselho Regional de Medicina do Estado de São Paulo, ano IV, $\left.\mathrm{n}^{\circ} 17\right]$.

Mattos AM. Direito internacional público. São Paulo: Saraiva; 1980.

Maximiliano C. Hermenêutica e aplicação do direito. Rio de Janeiro: Forense; 2001.

Mazzuoli VO. Tratados internacionais. São Paulo: Juarez de Oliveira; 2001.

Melhem A. Panorama geográfico do Brasil. São Paulo: Moderna; 2000.

Mello CDA. Curso de direito internacional público. Rio de Janeiro: Renovar; 2002.

Milaré E. Direito do ambiente. São Paulo: Revista dos Tribunais; 2000.

Milaré E. Agenda 21: a cartilha do desenvolvimento sustentável. Revista de Direito Ambiental. São Paulo: RT: 1997.

Montanhesi, MOR. Auditoria ambiental: dos primórdios à ISO 14000. São Paulo; 1997 [Dissertação de Mestrado - Faculdade de Saúde Pública da USP]. 
Moreira, IVD, coord. Vocabulário básico de meio ambiente. Fundação Estadual de Engenharia do Meio Ambiente. Rio de Janeiro: Petrobrás; 1992.

Morin E. Os sete saberes necessários à educação do futuro. [Tradução: Catarina Eleonora F. da Silva e Jeanne Sawaya]. São Paulo: Cortez; 2000.

Mousinho P. Glossário. In Meio ambiente no século 21. André Trigueiro, coordenador. Rio de Janeiro: Sextante; 2003.

Mukai T. Direito ambiental sistematizado. Rio de Janeiro: Forense; 2002.

Nietzsche FW. Para além do bem e do mal (fragmentos). [in Os Pensadores. Tradução Rubens Rodrigues Torres Filho]. São Paulo: Abril Cultural; 1978.

Odum E. Ecologia. Rio de Janeiro: Guanabara; 1988.

Oliveira AIA. O licenciamento ambiental. Rio de Janeiro: Iglu; 1999.

Oliveira RF. Princípios gerais de direito comunitário. In $\mathrm{O}$ direito internacional no terceiro milênio, Luiz Olavo Baptista e José Roberto Franco da Fonseca, coordenadores. São Paulo: LTR; 2002.

Panebianco $\mathrm{M}$. L'Organizzazione internazionale regionale. In $\mathrm{O}$ direito internacional no terceiro milênio, Luiz Olavo Baptista e José Roberto Franco da Fonseca, coordenadores. São Paulo: LTR; 2002.

Parisi M, Cotrim G. Trabalho dirigido de filosofia. São Paulo: Saraiva; 1996. 
Paschoal CMRB. Avaliação da qualidade ambiental de Cubatão. São Paulo; 1996 [Dissertação de Mestrado - Faculdade de Saúde Pública da USP].

Penna CG. O estado do planeta - sociedade de consumo e degradação ambiental. Rio de Janeiro: Record; 1999.

Pfafstetter O. Classificação das bacias hidrográficas: metodologia de codificação. Rio de Janeiro: DNOS; 1989.

Piernas CJ. El papel de la noción de consensus em la fundamentación y el concepto Del derecho internacional público. In $\mathrm{O}$ direito internacional no terceiro milênio, Luiz Olavo Baptista e José Roberto Franco da Fonseca, coordenadores. São Paulo: LTR; 2002.

Piovesan F. Direitos humanos e o direito constitucional internacional. São Paulo: Max Limonad; 1996.

Pompeu CT. Regime jurídico da polícia das águas públicas. São Paulo: CETESB; 1976.

Prestre PL. Ecopolítica internacional. São Paulo: Senac; 2000.

Purificação SBG. O desenvolvimento sustentável e a legislação ambiental do Estado de São Paulo. São Paulo; 2001 [Dissertação de Mestrado Faculdade de Saúde Pública da USP].

Puzatchenko IG. Pressupostos para a avaliação das ações antrópicas sobre o meio ambiente. In Previsão de Impactos. Clarita Muller-Plantenberg e Aziz Nacib Ab'Saber (organizadores). São Paulo: Edusp; 1998.

Rangel VM. Direito e relações internacionais. São Paulo: Revista dos Tribunais; 1993. 
Reis ACF. Súmula de história do Amazonas. Manaus: Governo do Estado do Amazonas; 1965

Reis VR. A Agenda 21 Local: uma abordagem crítica. São Paulo; 1999 [Dissertação de Mestrado - Universidade Presbiteriana Mackenzie].

Rezek JF. Direito internacional público: curso elementar. São Paulo: Saraiva; 1996.

Ridruejo JAP. EI Estado como sujeto del derecho internacional. In: Curso de derecho internacional público y organizaciones internacionales. Madrid: Tecnos; 1996.

Rocha AA. Fatos históricos do saneamento. São Paulo: Scortecci; 1997.

Rocha AA. Tietê, rio poético - uma coletânea. São Paulo: Universidade de São Paulo. Faculdade de Saúde Pública. Departamento de Saúde Ambiental; 1997.

Rocha AA. Ciências do ambiente, saneamento, saúde pública. São Paulo: Universidade de São Paulo. Faculdade de Saúde Pública. Departamento de Saúde Ambiental; 1995.

Rodrigues MA. Instituições de direito ambiental. São Paulo : Max Limonad; 2002.

Ross JLS (org.). Geografia do Brasil. São Paulo: Edusp; 2000.

Rovere, EL (coord.). Manual de auditoria ambiental. Rio de Janeiro: Qulalitymark; 2001. 
Russel B. História do pensamento ocidental. Rio de Janeiro: Ediouro; 2001.

Seintenfus R. Ventura D. Introdução ao Direito Internacional Público. Porto Alegre: Livraria do Advogado; 1999.

Sene E, Moreira JC. Geografia geral e do Brasil. São Paulo: Scipione; 2000.

Silva CCA. Controle de poluição das águas. São Paulo: Universidade de São Paulo. Faculdade de Saúde Pública da USP. Departamento de Saúde Ambiental; 1998 [material apostilado].

Silva DP. Vocabulário jurídico. Rio de Janeiro: Forense; 1997.

Silva FQ. Limites internacionais de aplicação da legislação pesqueira nacional: pesca e conflitos internacionais. Revista de Direito Ambiental. São Paulo: RT; 1998.

Silva GEN. Direito ambiental internacional. Rio de Janeiro: Thex; 1995.

Silva JA. Curso de direito constitucional positivo. São Paulo: Malheiros; 2000.

Sirvinskas LP. Manual de direito ambiental. São Paulo: Saraiva; 2002.

Soares GFS. Direito internacional do meio ambiente. São Paulo: Atlas; 2001.

Souza SMR. Um outro olhar. São Paulo: FTD; 1995. 
Strenger I. Relações internacionais. São Paulo: LTR; 2002.

Sung JM. Silva JC. Conversando sobre ética e sociedade. Petrópolis: Vozes; 1998.

Tibor T. Feldman I. ISO 14000: um guia para as novas normas de gestão ambiental. São Paulo: Futura; 1996.

Torres H. Costa H. População e meio ambiente (debates e desafios). São Paulo: Senac; 2000.

Trindade AAC. A proteção internacional dos direitos humanos: fundamentos jurídicos e instrumentos básicos. São Paulo: Saraiva; 1991.

Vazques AS. Ética. Rio de Janeiro: Civilização Brasileira; 1992.

Vesentini JW. Brasil: sociedade e espaço. Geografia do Brasil. São Paulo: Ática; 1999.

Viana RGC. A política ambiental em nível internacional e sua influência no direito pátrio. In $\mathrm{O}$ direito internacional no terceiro milênio, Luiz Olavo Baptista e José Roberto Franco da Fonseca, coordenadores. São Paulo: LTR; 2002.

Vianna RC. Moreira FK. $O$ papel atual das organizações internacionais e a inserção brasileira. In: Âmbito Jurídico, mar/2001 [Internet] http://www.ambito-juridico.com.br/aj/di0003.html

Vicuña FO. Changing perspectives of international law in áreas of global concern: the oceans, Antarctica and the environment. In $\mathrm{O}$ direito internacional no terceiro milênio, Luiz Olavo Baptista e José Roberto Franco da Fonseca, coordenadores. São Paulo: LTR; 2002. 
Vignali HA. O atributo da soberania. In Estudos da Integração, v. 9. Porto Alegre: Associação Brasileira de Estudos da Integração; 1995.

Viola E. Meio ambiente. Relações internacionais. As complexas negociações internacionais para atenuar as mudanças climáticas. In Meio ambiente no século 21. André Trigueiro, coordenador. Rio de Janeiro: Sextante; 2003.

Vukas B. Some recent aspects of the implementation of the right of peoples to self-determination. In $\mathrm{O}$ direito internacional no terceiro milênio, Luiz Olavo Baptista e José Roberto Franco da Fonseca, coordenadores. São Paulo: LTR; 2002.

Banco de Dados - LEMA Consultoria S/C Ltda. São Paulo; 1998.

Bíblia Sagrada, tradução de Padre Antonio Pereira de Figueiredo, Rio de Janeiro: Delta; 1980.

Brasil. Constituição da República Federativa do Brasil, de 05 de outubro de 1988. São Paulo: Saraiva; 2002.

Dicionário Moderno da língua Portuguesa. São Paulo: Rideel; 1986.

Dicionário Contemporâneo da Língua Portuguesa Caldas Aulete. São Paulo: Delta; 1988.

Enciclopédia Larousse Cultural. São Paulo: Nova Cultural; 1990.

Enciclopédia Delta Universal. Rio de Janeiro: Delta, 1988. 
Legislação do Meio Ambiente: Atos Internacionais e Normas Federais. Brasilia: Senado Federal, Primeira Secretaria, Subsecretaria de Edições Técnicas; 1996.

Legislação Estadual: Controle da Poluição Ambiental. Série Documentos. São Paulo: CETESB; 1995.

Legislação Federal: Controle da Poluição Ambiental, Série Documentos. São Paulo: CETESB; 1995.

\author{
www.abnt.org.br \\ www.ambiente.sp.gov.br \\ www.ana.gov.br \\ www.cetesb.gov.br \\ www.enciclopedia.com.br \\ www.ibama.gov.br \\ www.ibge.com.br \\ www.info.Incc.br \\ www.mma.gov.br \\ www.mre.gov.br \\ www.scdl.gov.br
}




\begin{abstract}
ANEXOS

\section{A.1. El derecho de los usos de los cursos de água internacionales para} fines distintos de la navegación ${ }^{142}$
\end{abstract}

\title{
PARTE I: INTRODUCCIÓN
}

Artículo 1.- Ámbito de aplicación de los presentes artículos

1. Los presentes artículos se aplican a los usos de los cursos de agua internacionales y de sus aguas para fines distintos de la navegación y a las medidas de conservación y gestión relacionadas con los usos de esos cursos de agua y de sus aguas.

2. El uso de los cursos de agua internacionales para la navegación no está comprendido en el ámbito de aplicación de los presentes artículos salvo en la medida en que otros usos afecten a la navegación o resulten afectados por ésta.

Artículo 2.- Términos empleados

A los efectos de los presentes artículos:

a) Se entiende por "curso de agua internacional" un curso de agua algunas de cuyas partes se encuentran en Estados distintos;

b) Se entiende por "cursos de agua" un sistema de aguas de superficie y subterránea que, en virtud de su relación física, constituyen un conjunto unitario y normalmente fluyen a un término común;

c) Se entiende por "Estado del curso de agua" un Estado en el territorio del cual se encuentra parte de un curso de agua internacional.

\footnotetext{
${ }^{142}$ Convenção das Naçðes Unidas sobre o direito das utilizaç̃es dos cursos d'água internacionais para fins distintos da navegação. Nova York, Agência da Organização das Naçðes Unidas - ONU, 21 de Maio de 1997, Resolução A/51/869.
} 
Artículo 3.- Acuerdos de curso de água

1. Los Estados del curso de agua podrán celebrar uno o varios acuerdos, en adelante denominados "acuerdos de curso de agua", que apliquen y adaten las disposiciones de los presentes artículos a las caracteristicas y usos de un curso de agua internacional determinado o de parte de ese curso de agua.

2. Si entre dos o más Estados del curso de agua se celebra un acuerdo de curso de agua, ese acuerdo definirá las aguas a las que se aplique. Dicho acuerdo podrá celebrarse respecto de la totalidad de un cursos de agua internacional o respecto de cualquiera de sus parte o de un proyecto, programa o uso particular, siempre que el acuerdo no menoscabe de manera sensible el uso de las aguas del curso de agua por otro Estado $u$ otros Estados del curso de agua.

3. Si un Estado del curso de agua considera que las caracteristicas y usos de un curso de agua internacional determinado requieren la adaptación o aplicación de las disposiciones de los presentes artículos, los Estados del curso de agua celebrarán consultas con el propósito de negociar de buena fe a fin de celebrar uno o varios acuerdos de curso de agua.

Artículo 4.- Partes en acuerdos de curso de água

1. Todo Estado del curso de agua tiene derecho a participar en la negociación de cualquier acuerdo de curso de agua que se aplique a la totalidad de ese curso de agua internacional y a llegar a ser parte en tal acuerdo, así como a participar en cualesquiera consultas pertinentes.

2. El Estado del curso de agua cuyo uso de un curso de agua internacional pueda resultar afectado de manera sensible por la ejecución de un acuerdo de curso de agua propuesto que solamente se aplique a una parte del curso de agua o a un proyecto, programa o uso particular tendrá derecho a participar en las consultas sobre tal acuerdo y en su negociación, en la medida en que su uso resulte por ese acuerdo, y a llegar a ser parte en él. 


\section{PARTE II: PRINCIPIOS GENERALES}

Artículo 5.- Utilización y participación equitativas y razonables

1. Los Estados del curso de agua utilizarán en sus territorios respectivos un curso de agua internacional de manera equitativa y razonable. En particular, los Estados del curso de agua utilizarán u aprovecharán un curso de agua internacional con el propósito de lograr un utilización óptima y un disfrute máximo compatibles con la protección adecuada del curso de agua internacional.

2. Los Estados del cursos de agua participarán en el uso, aprovechamiento $\mathrm{y}$ protección de un curso de agua internacional de manera equitativa y razonable. Esa participación incluye tanto el derecho de utilizar el curso de agua como la obligación de cooperar en su protección y aprovechamiento, conforme lo dispuesto en los presentes artículos.

Artículo 6.- Factores pertinentes en una utilización equitativa y razonable 1. La utilización de manera equitativa y razonable de un curso de agua internacional de conformidad con el artículo 5 requiere que se tengan en cuenta todos los factores y circunstancias pertinentes, entre otros:

a) Los factores geográficos, hidrográficos, hidrológicos, climáticos, ecológicos y otros factores naturales;

b) Las necesidades económicas y sociales de los Estados del curso de agua interesados;

c) La dependencia de la población respecto del curso de agua;

d) Los efectos que el uso o los usos del curso de agua en uno de los Estados del curso de agua produzcan en otros Estados del curso de agua;

e) Los usos existentes y potenciales del curso de agua;

f) La conservación, la protección, el aprovechamiento y la economía en la utilización de los recursos hídricos del curso de agua y el costo de las medidas adoptada a tal efecto; 
g) La existencia de alternativas, de valor correspondiente, respecto de un uso particular existe o previsto.

2. En la aplicación del artículo 5 o del párrafo 1 de este artículo, los Estados del curso de agua interesados celebrarán, de ser necesario, consultas con ánimo de cooperación.

Artículo 7.- Obligación de no causar daños sensibles

1. Los Estados del curso de agua ejercerán la diligencia debida para utilizar el curso de agua internacional de manera que no se causen daños sensibles a otros Estados del curso de agua.

2. Cuando, a pesar del ejercicio de diligencia debida, se causen daños sensibles a otro Estado del curso de agua, el Estado cuyo uso cause los daños deberá, a falta de acuerdo con respecto a ese uso, consultar con el Estado que sufra dichos daños acerca de:

a) La medida en que ese uso es equitativo y razonable teniendo en cuenta los factores enumerados en el artículo 6;

b) La cuestión de los ajustes especiales de su utilización, destinados a eliminar o mitigar los daños causados y, cuando proceda, la cuestión de la indemnización.

Artículo 8.- Obligación general de cooperación

Los Estados del curso de agua cooperarán con arreglo a los principios de la igualdad soberana, la integridad territorial y el provecho mutuo a fin de lograr una utilización óptima y una protección adecuada de un curso de agua internacional.

Artículo 9.- Intercambio regular de datos e información

1. De conformidad con el artículo 8, los Estados del curso de agua intercambiarán regularmente los datos y la información que sean fácilmente accesibles sobre el estado del curso de agua, en particular los de carácter hidrológico, meteorológico, hidrogeológico y ecológico, así como las previsiones correspondientes. 
2. E Estado del curso de agua al que otro Estado del curso de agua le pida que proporcione datos e información que no sean fácilmente accesibles hará lo posible por atender esta petición, pero podrá exigir que el Estado solicitante pague los costos razonables de reunión, en su caso, elaboración de esos datos e información.

3. Los Estados del curso de agua harán lo posible por reunir $y$, en su caso, elaborar los datos y la información de manera que se facilite su utilización por los Estados del curso de agua a los que se comuniquen.

Artículo 10.- Relación entre las diferentes clases de usos

1. Salvo pacto o costumbre en contrario, ningún uso de un curso de agua internacional tiene en sí prioridad sobre otros usos.

2. El conflicto entre varios usos de un curso de agua internacional se resolverá basándose en los principios y factores enunciados en los artículos 5 a 7 , teniendo en cuenta especialmente la satisfacción de las necesidades humanas esenciales.

\section{PARTE III: MEDIDAS PROYECTADAS}

Artículo 11.- Información sobre las medidas proyectadas

Los Estados del curso de agua intercambiarán información y se consultarán acerca de los posibles efectos de las medidas proyectadas sobre el estado de un curso de agua internacional.

Artículo 12.- Notificación de las medidas proyectadas que puedan causar un efecto perjudicial

El Estado del curso de agua, antes de ejecutar o permitir la ejecución de las medidas proyectada que puedan causar un efecto perjudicial sensible a otros Estados del curso de agua, lo notificar oportunamente a esos Estados. 
Esa notificación irá acompañada de los datos técnicos y la información disponibles para que los Estados a los que se haga la notificación puedan evaluar los posibles efectos de las medidas proyectadas.

Artículo 13.- Plazo para responder a la notificación a menos que se hubiere acordado otra cosa

a) El Estado del curso de agua que haga la notificación a que se refiere el artículo 12 dará a los Estados a los que haga esa notificación un plazo de seis meses para estudiar y evaluar los posibles efectos de las medidas proyectadas y comunicarle sus conclusiones;

b) Ese plazo se prorrogará a petición de uno de los Estado destinatarios de la notificación al que la medida proyectada cause dificultades especiales, por un período que no excederá seis meses.

Artículo 14.- Obligaciones del Estado notificante durante el plazo de respuesta

Durante el plazo a que se refiere el artículo 13, el Estado notificante cooperar con los Estados a los que se haba la notificación facilitándoles, cuando se lo pidan, cualesquiera otros datos e información adicionales de que disponga y que sean necesarios para una evaluación precisa, y no ejecutará ni permitirá la ejecución de las medidas proyectada sin el consentimiento de los Estados a los que se haga la notificación.

\section{Artículo 15.- Respuesta a la notificación}

1. Los Estados a los que saya hecho la notificación comunicarán lo antes posible sus conclusiones al Estado notificante.

2. El Estado al que se haya hecho la notificación, si llegare a la conclusión de que la ejecución de las medidas proyectadas sería incompatible con las disposiciones de los artículos 5 ó 7 , comunicará al Estado notificante, dentro del plazo aplicable a tenor del artículo 13, esa conclusión a la que acompañara una exposición documentada de las razones en que aquélla se funde. 
Artículo 16.- Falta de respuesta a la notificación

1. El Estado notificante, si no recibe dentro del plazo aplicable a tenor del artículo 13 ninguna de las comunicaciones previstas en el párrafo 2 del artículo 15 , podrá iniciar, sin perjuicio de las obligaciones que le incumban a tenor de lo dispuesto en los artículos 5 y 7 , la ejecución de las medidas proyectadas, de conformidad con la notificación y cualesquiera otros datos e información suministrados a los Estados a los que se haya hecho la notificación.

2. Podrán deducirse de toda reclamación de indemnización de un Estado al que haya hecho la notificación sin que haya formulado respuesta los costos en que haya incurrido el Estado notificante en concepto de medidas adoptadas tras la expiración del plazo de respuesta y que no habrá adoptado si el Estado al que haya hecho la notificación hubiera presentado una objeción dentro del plazo aplicable a tenor del articulo 13.

Artículo 17.- Consultas y negociaciones sobre las medida proyectadas

1. En caso de que se haga una comunicación de conformidad con el párrafo 2 del artículo 15, el Estado notificante y el Estado autor de la comunicación iniciarán consultas y, si es necesario, negociaciones para llegar a una solución equitativa.

2. Las consultas y negociaciones se celebrarán con arreglo al principio de que cada Estado debe tener razonablemente en cuenta de buena fe los derechos y los intereses legítimos del otro Estado.

3. Durante las consultas y negociaciones, el Estado notificante no ejecutará ni permitirá la ejecución de las medidas proyectadas, por un plazo que no excederá de seis meses, si el Estado a que se haya hecho la notificación lo solicita en el momento en que haga la comunicación. 
Artículo 18.- Procedimientos aplicables a falta de notificación

1. Todo Estado del curso de agua que tenga razones graves para creer que otro Estado del curso de agua proyecta tomar medidas que pueden causarle un efecto perjudicial sensible podrá pedir a éste que aplique las disposiciones del artículo 12. La petición irá acompañada de una exposición documentada de sus razones.

2. En caso de el Estado que proyecte tomar las medidas llegue no obstante a la conclusión de que no está obligado a hacer la notificación a que se refiere el artículo 12, lo comunicará al otro Estado y le presentará una exposición documentada de las razones en que se funde esa conclusión. Si el otro Estado no está de acuerdo con esa conclusión, los dos Estados iniciarán sin demora, a petición de ese otro Estados, consultas y negociaciones en la forma indicada en los párrafos 1 y 2 del artículo 17.

3. Durante las consultas y negociaciones, el Estado que proyecte tomar las medidas no las ejecutará ni permitirá su ejecución, por un plazo que no excederá de seis meses, si el otro Estado lo solicita en el momento en que pida que se inicien las consultas y negociaciones.

Artículo 19.- Ejecución urgente de las medidas proyectadas

1. En caso de que la ejecución de las medidas proyectadas sea de extrema urgencia para proteger la salud y la seguridad públicas u otros intereses igualmente importantes, el Estado que proyecte tomar las medidas podrá, sin perjuicio de lo dispuesto en los artículos 5 y 7 , iniciar inmediatamente su ejecución, no obstante lo dispuesto en el artículo 14 y en el párrafo 3 del artículo 17.

2. En tales casos, se hará un declaración formal sobre la urgencia de las medidas a los demás Estados del curso de agua a los que se refiere el artículo 12, y se transmitirán a éstos los datos y la información pertinentes. 
3. Es Estado que proyecte tomar las medidas iniciará sin demora, con cualquiera de los Estados indicados en el párrafo 2 que lo solicite, consultas y negociaciones en la forma indicada en los párrafos 1 y 2 del artículo 17.

\section{PARTE IV: PROTECCIÓN, PRESERVACIÓN Y GESTIÓN}

Artículo 20.- Protección y preservación de los ecosistemas

Los Estados del curso de agua protegerán y preservarán, individual o conjuntamente, los ecosistemas de los cursos de agua internacionales.

Artículo 21.- Prevención, reducción y control de contaminación 1. A los efectos de este artículo, se entiende por "contaminación de un curso de agua internacional" toda alteración nociva de la composición o calidad de las aguas de un curso de agua internacional que resulte directa $o$ indirectamente de un comportamiento humano.

2. Los Estados del curso de agua, prevendrán, reducirán y controlarán, individual o conjuntamente, la contaminación de un curso de agua internacional que pueda causar daños sensibles a otros Estados del curso de agua o a su medio ambiente, incluidos los daños a la salud o la seguridad humanas, a la utilización de las aguas con cualquier fin útil a los recursos vivos del curso de agua. Los Estados del curso de agua tomarán disposiciones para armonizar su política a este respecto.

3. Los Estados del curso de agua celebrarán, a petición de cualquiera de ellos, consultas con el propósito de confeccionar listas de substancias cuya introducción en las aguas de un curso de agua internacional haya de ser prohibida, limitada, estudiada o vigilada. 
Artículo 22.- Introducción de especies extrañas o nuevas

Los Estados del curso de agua tomarán todas las medidas necesarias para impedir la introducción, en un curso de agua internacional, de especies extrañas o nuevas que produzcan o puedan producir efectos nocivos para el ecosistema del curso de agua que origen en daños sensibles para otros Estados del curso de agua.

Artículo 23.- Protección y preservación del medio marino

Los Estados del curso de agua tomarán, individual o conjuntamente, todas las medidas con respecto a un curso de agua internacional que sean necesarias para proteger y preservar el medio marino, incluidos los estuarios, tiendo en cuenta las reglas internacionales generalmente aceptadas.

\section{Artículo 24.- Gestión}

1. Los Estados del curso de agua entablarán, a petición de cualquiera de ellos, consultas sobre la gestión de un curso de agua internacional, incluida eventualmente la creación de un órgano mixto de gestión.

2. A los efectos de este artículo, se entiende por "gestión", en particular:

a) El hecho de planificar el aprovechamiento sostenible de un curso de agua internacional y de velar por la ejecución de los planes que se adopten;

b) El hecho de promover de otro modo la utilización racional y óptima, la protección y el control del curso de agua.

\section{Artículo 25.- Regulación}

1. Los Estados del curso de agua cooperarán según proceda en lo concerniente a las necesidades o posibilidades de regulación del caudal de las aguas de un curso de agua internacional. 
2. Salvo que hayan acordado otra cosa, los Estados del curso de agua participarán de manera equitativa en la construcción y el mantenimiento o la financiación de las obras de regulación que hayan convenido en ejecutar.

3. A los efectos de este artículo, se entiende por "regulación" la utilización de obras hidráulicas o cualquier otra medida estable para alterar, modificar o controlar de otro modo el caudal de las aguas de un curso de agua internacional.

Artículo 26.- Instalaciones

1. Los Estados de curso de agua harán lo posible, dentro de sus respectivos territorios, por mantener y proteger las instalaciones, construcciones y otras obras relacionadas con un curso de agua.

2. Los Estados del curso de agua entablará, a petición de cualquiera de ellos que tenga razones graves para creer que pueda sufrir efectos perjudiciales sensibles, consultas sobre:

a) El buen funcionamiento o mantenimiento de las instalaciones, construcciones y otras obras relacionadas con un curso de agua.

b) La protección de las instalaciones, construcciones $u$ otras obras contra actos dolosos o culposos o contra las fuerzas naturales.

\section{PARTE V: EFECTOS NOCIVOS Y CASOS DE URGENCIA}

Artículo 27.- Medidas para prevenir y atenuar los efectos nocivos Los Estados del curso de agua tomarán, individual o conjuntamente, todas las medidas apropiadas para prevenir o atenuar los efectos que resulten de causas naturales o de un comportamiento humano, como crecidas o deshielos, enfermedades de origen hídrico, entarquinamiento, erosión, intrusión de agua salada, sequía o desertificación, que puedan ser nocivos para otros Estados del curso de agua. 
Artículo 28.- Casos de urgencia

1. A los efectos de este artículo, se entiende por "caso de urgencia' toda situación que causa graves daños a los Estados del curso de agua o a otros Estados, o crea un peligro inminente de causar tales daños, y que resulta súbitamente de causas naturales, como las crecidas, el deshielo, los desprendimientos de tierras o los terremotos, o de un comportamiento humano, con en el caso de los accidentes industriales.

2. Todo Estado del curso de agua notificará sin demora y por los medios más rápidos de que disponga a los demás Estados que puedan resultar afectados y las organizaciones internacionales competentes cualquier caso de urgencia que sobrevenga en su territorio.

3. El Estado del curso de agua en cuyo territorio sobrevenga un caso de urgencia tomará inmediatamente, en cooperación con los Estados que puedan resultar afectados $\mathrm{y}$, cuando proceda, las organizaciones internacionales competentes, todas las medidas posibles que requieran las circunstancias para prevenir, atenuar y eliminar los efectos nocivos del caos de urgencia.

4. De ser necesario, los Estados del curso de agua elaborarán conjuntamente planes para hacer frente a los casos de urgencia, en cooperación, cuando proceda, con los demás Estados que puedan resultar afectados y las organizaciones internacionales competentes.

\section{PARTE VI: DISPOSICIONES DIVERSAS}

Artículo 29.- Cursos de agua internacionales e instalaciones en tiempo de conflicto armado

Los cursos de agua internacionales y las instalaciones, construcciones y otras obras conexas gozarán de la protección que les confieren los principios y normas de derecho internacional aplicables en caso de conflicto armado internacional o interno y no serán utilizados en violación de esos principios y normas. 
Artículo 30.- Procedimientos indirectos

Cuando haya graves obstáculos para establecer contactos directos entre Estados del curso de agua, los Estados interesados cumplirán las obligaciones de cooperación que les incumben con arreglo a los presentes articulos mediante el intercambio de datos e información, la notificación, la comunicación, las consultas y las negociaciones, por cualquier procedimiento indirecto que hayan aceptado.

Artículo 31.- Datos e información vitales para la defensa y la seguridad nacionales

Nada de lo dispuesto en los presentes artículos obliga a ningún Estado del curso de agua a proporcionar datos o información que sean vitales para su defensa o seguridad nacionales. No obstante, todos Estado del curso de agua cooperará de buena fe con los demás Estados del curso de agua para proporcionar toda la información que sea posible según las circunstancias.

\section{Artículo 32.- No discriminación}

Salvo que los Estados del curso de agua interesados hayan acordado otra cosa para la protección de los intereses de las personas, naturales o jurídicas, que hayan sufrido daños transfronterizos sensibles a consecuencia de actividades relacionadas con un curso de agua internacional, o que estén expuestas a un riesgo grave de sufrir tales daños, los Estados del curso de agua no incurrirán en discriminación basada en la nacionalidad o la residencia o el lugar en que se produjeron los daños por lo que respecta al reconocimiento de la libertad de acceso de esas personas, de conformidad con sus ordenamientos jurídicos al proceso judicial $o$ de otra índole, o de su derecho a reclamar indemnización $u$ otro resarcimiento de los daños sensibles causados por tales actividades realizadas bajo su jurisdicción. 
Artículo 33.- Solución de controversias

1. A falta de acuerdo aplicable entre los Estados del curso de agua interesados, cualquier controversia relativa al curso de agua con respecto a una cuestión de hecho o a la interpretación o aplicación de los presentes artículos se solucionará con arreglo a las disposiciones siguientes:

a) Si surge una cuestión de esa naturaleza, los Estados interesados iniciarán sin demora consultas y negociaciones con miras a lograr soluciones equitativas de controversia, utilizando, como corresponda, las instituciones conjuntas del curso de agua que hubieren establecido.

b) Si, en ningún momento una vez transcurridos seis meses desde la fecha de la petición de consultas y negociaciones, los Estados interesados no han logrado una solución de las controversias mediante la celebración de consultas y negociaciones, esos Estados, a petición de cualquiera de ellos, recurrirán a un método imparcial de determinación de los hechos o, si lo acuerdan los Estados interesados, a la mediación o la conciliación.

I. A menos que acuerda otra cosa, se establecerá una comisión de determinación de los hechos, integrada por un miembro designado por cada Estado interesado y además por un miembro que no tenga la nacionalidad de ninguno de los Estados interesados que será elegido por los miembros designados y que actuará de presidente.

II. Si los miembros designados por los Estados no pueden ponerse de acuerdo en el nombramiento de presidente en un plazo de cuatro meses a contar desde la solicitud de establecimiento de la comisión, cualquiera de los Estados interesados podrá solicitar del Secretario General de las Naciones Unidas que nombre presidente. Si uno de los Estados no designa miembro para la comisión en un plazo de cuatro meses a contar desde a solicitud inicial presentada con arreglo al párrafo b), cualquier otro Estado interesado podrá solicitar del Secretario General de las Naciones Unidas que designe a una persona que no tenga la nacionalidad de ninguno de los Estados interesados, la cual constituirá una comisión unipersonal. 
III. La comisión determinará su propio procedimiento.

IV. Los Estados interesados tienen la obligación de proporcionar a la comisión la información que solicite y, previa petición, permitirle tener acceso a su territorio respectivo e inspeccionar cualesquiera instalaciones, planta, equipo, construcción o particularidad física que sea pertinente a los efectos de su investigación.

V. La comisión aprobará su informe por mayoría, a menos que sea una comisión unipersonal, y lo presentará a los Estados interesados, exponiendo en él sus conclusiones y los fundamentos de las mismas, así como las recomendaciones que considere apropiadas.

VI. Los gastos de la comisión serán sufragados a partes iguales por los Estados interesados.

c) Si los Estados interesados no han podido solucionar la controversia después de transcurridos 12 meses desde la petición inicial de que se recurra a la determinación de los hechos, la mediación o la conciliación o, después de transcurridos seis meses desde la recepción del informe de la comisión, según cuál de estos plazos se cumpla después, podrán mediante acuerdo someter la controversia a arbitraje o arreglo judicial. 
A2. Resolución sobre las aguas subterráneas transfronterizas ${ }^{143}$

La Comisión de Derecho Internacional,

Habiendo completado su examen del tema sobre "El derecho de los usos de los cursos de agua internacionales para fines distintos de la navegación,

Habiendo examinado en ese contexto las aguas subterráneas relacionadas con un curso de agua internacional,

Reconociendo que la aguas subterráneas confinadas, que son aguas subterráneas no relacionadas con un curso de agua internacional, constituyen también un recurso natural de ital importancia para el sostenimiento de la vida, la salud y la integridad de los ecosistemas,

Reconociendo también la necesidad de realizar esfuerzos continuados para elaborar normas relativas a las aguas subterráneas confinadas transfronterizas,

Considerando su opinión de que los principios contenidos en su proyecto de artículos sobre el derecho de los usos de los cursos de agua internacionales para fines distintos de navegación pueden aplicarse a las aguas subterráneas confinas transfronterizas,

143 Resolução da Comissão de Direito Internacional das Naçðes Unidas, sobre Lençóis Freáticos Transfronteiriços. 
1. Exhorta a los Estados a que guien por los principios contenidos en el proyecto de artículos sobre el derecho de los usos de los cursos de agua internacionales para fines distintos de la navegación, cuando proceda, en la regulación de las aguas subterráneas transfronterizas;

2. Recomienda a los Estados que consideren la posibilidad de concertar acuerdos con el otro Estado o los otros Estados en que se encuentran las aguas subterráneas confinadas transfronterizas;

3. Recomienda asimismo que, en caso de que surja un controversia relacionada con aguas subterráneas confinadas transfronterizas, los Estados interesados consideren la posibilidad de resolverla de conformidad con las disposiciones contenidas en el artículo $33 \mathrm{del}$ proyecto de artículos o de cualquier otra manera que se convenga. 


\section{A3. Atos internacionais sobre meio ambiente no direito brasileiro}

a) Principais convenções e protocolos vigentes no Brasil:

- Protocolo de Genebra sobre Proibição e Emprego na Guerra de Gases Asfixiantes, Tóxicos ou Similares e de Meios Bacteriológicos de Guerra, 1925. Decreto $n^{\circ} 67.200$ de 19/06/1970;

+ Convenção Internacional para a Regulamentação da Pesca da Baleia, Genebra, 1931. Decreto ${ }^{\circ} 23.456$ de 14/11/1933;

\ Convenção da Haia para a Proteção de Bens Culturais em Caso de Conflito Armado, de 1954. Aprovada pelo Decreto Legislativo $\mathrm{n}^{\circ} 32$ de 14/08/1956 e Promulgada pelo Decreto $n^{\circ} 44851$ de 11/11/1958;

- Convenção para a Proteção da Flora, da Fauna e das Belezas Naturais dos Países da América, Washington, 1940. Decreto $\mathrm{n}^{\circ} 58.054$ de 23/03/1966; Protocolo promulgado pelo Decreto $n^{\circ} 46.873$ de 16/09/1959;

- Convenção Internacional para a Regulamentação da Pesca da Baleia e Protocolo para a Regulamentação da Pesca da Baleia, Washington, 1946. Decreto $n^{\circ} 73.497$ de 17/01/1974;

- Convenção Internacional para a Proteção dos Vegetais, Roma, 1951. Decreto $n^{\circ} 51.342$ de 28/10/1961;

- Tratado da Antártica, Washington, 1959. Decreto $\mathrm{n}^{\circ} 75.963$ de 11/07/1975;

- Convenção Relativa à Proteção dos Trabalhadores contra Radiações Ionizantes, Genebra, OIT, 1960. Decreto $n^{\circ} 62.151$ de 19/01/1968; 
- Tratado de Proscrição das Experiências com Armas Nucleares na Atmosfera, no Espaço Cósmico e sob a Água, Moscou, 1963. Decreto $n^{\circ} 58.256$ de 26/06/1966;

+ Convenção de Viena sobre Responsabilidade Civil por Danos Nucleares, concluida sob a égide da AIEA em 1963. Decreto $n^{\circ} 911$ de 03/09/1993.

\ Convenção Internacional para a Conservação do Atum e Afins, do Atlântico, Rio de Janeiro, 1966. Decreto ${ }^{\circ} 412$ de 09/01/1969;

- Tratado para a Proscrição de Armas Nucleares na América Latina (Tratado de Tlatelolco), Cidade do México, 1967. Decreto ${ }^{\circ} 1.246$ de 16/09/1994;

- Tratado sobre Princípios Reguladores das Atividades dos Estados na Exploração e Uso do Espaço Cósmico, Inclusive a Lua e Demais Corpos Celestes, Londres, Moscou, Washington, 1967. Decreto $\mathrm{n}^{\circ}$ 64.362 de 17/04/1969;

+ Convenção Internacional sobre Responsabilidade Civil em Danos Causados por Poluição por Óleo, Bruxelas, 1969. Decreto $n^{\circ} 79.437$ de 28/03/1977 e regulamentada pelo Decreto $n^{\circ} 83.540$ de 04/06/1979;

- Tratado da Bacia do Prata, Brasília, 1969. Decreto $n^{\circ} 67.084$ de 19/08/1970. O Decreto ${ }^{\circ} 81.351$ de 17/02/1978 promulgou o Tratado da Lagoa Mirim;

- Convenção sobre Medidas a Serem Adotadas para Proibir e Impedir a Importação, Exportação e Transferência de Propriedade Ilícita de Bens Culturais, Paris (UNESCO) 1970. Decreto n 72.312 de 31/05/1973;

\ Convenção sobre Responsabilidade Internacional por Danos Causados por Objetos Espaciais, Londres, Moscou e Washington, 1972. Decreto $\mathrm{n}^{\circ} 71.981$ de 22/03/1973;

- Protocolo relativo à Intervenção em Alto Mar nos Casos de Poluição Marinha por Substâncias além do Óleo, Londres, 1973. Decreto $\mathrm{n}^{\circ}$ 79.437 de 28/03/1977; 
- Convenção para a Conservação das Focas Antárticas, Londres, 1972. Decreto $n^{\circ} 66$ de 18/03/1991;

- Tratado sobre a Proibição da Colocação de Armas Nucleares e Outras Armas de Destruição em Massa no Leito do Mar, e no Fundo do Oceano e em Seu Subsolo, Londres, Moscou, Washington, 1971. Decreto $\mathrm{n}^{\circ}$ 97.211 de 12/12/1988, com reservas;

\Convenção sobre a Proibição do Desenvolvimento, Produção e Armazenamento de Armas Bacteriológicas (Biológicas) e de Toxinas, e Sua Destruição, Londres, Moscou, Washington, 1972. Decreto $\mathrm{n}^{\circ}$ 77.374 de 01/04/1976;

- Convenção relativa à Proteção do Patrimônio Mundial, Cultural e Natural, Paris, (UNESCO), 1972. Decreto $n^{\circ} 80.978$ de 12/12/1977;

\ Convenção sobre Prevenção de Poluição Marinha por Alijamento de Resíduos e Outras Matérias (com emendas), Londres, Cidade do México, Moscou (Washington), 1972. Decreto $\mathrm{n}^{\circ} 87.566$ de 16/09/1082;

- Convenção sobre Comércio Internacional das Espécies da Flora e da Fauna Selvagens em Perigo de Extinção, Washington, 1973, com emendas. Decreto $\mathrm{n}^{\circ} 76.623$ de $17 / 11 / 1975$. Com as emendas votadas em Gaborone, em 1983, promulgadas pelo Decreto $\mathrm{n}^{\circ}$ 92.446/86 e as emendas votadas em Bonn, em 1979, promulgadas pelo Decreto $\mathrm{n}^{\circ}$ 133 de 24/05/1991;

- Convenção sobre a Proibição da Utilização de Técnicas de Modificação Ambiental para Fins Militares ou Quaisquer Outros Fins Hostis, Nova York (ONU), 1976. Decreto $n^{\circ} 225$ de 07/10/1991;

Convenção sobre a Proteção dos Trabalhadores contra Riscos Profissionais devidos à Contaminação do Ar, ao Ruído e às Vibrações no Local de Trabalho, Genebra, OIT, 1977. Decreto $n^{\circ} 93.413$ de 15/10/1986;

Tratado de Cooperação Amazônica, Brasília, 1978. Decreto nº 85.050 de 18/08/1990; 
Convenção sobre Proteção Física de Material Nuclear, Viena, AIEA, 1979. Decreto $n^{\circ} 95$ de 16/04/1991;

- Convenção sobre a Conservação de Recursos Vivos Marinhos Antárticos, Camberra, 1980. Decreto ${ }^{\circ} 93.935$ de 15/01/1987;

- Protocolo Adicional à Convenção para a Conservação do Atum e Afins do Atlântico, Paris, 1984. Decreto $n^{\circ} 97.612$ de 04/04/1989;

+ Convenção de Viena para a Proteção da Camada de Ozônio, Viena, 1985. Decreto $n^{\circ} 99.280$ de 06/06/1990;

- Protocolo de Montreal sobre Substâncias que Destroem a Camada de Ozônio, Montreal, 1987. Decreto ${ }^{\circ} 99.280$ de 06/06/1990;

- Ajustes do Protocolo de Montreal sobre Substâncias que Destroem a Camada de Ozônio, adotados em 29/06/1990. Promulgados pelo Decreto $n^{\circ} 181$ de 25/07/1991;

+ Convenção sobre Pronta Notificação de Acidentes Nucleares, Viena, AIEA, 1986. Decreto $n^{\circ} 9$ de 15/01/1991;

- Convenção sobre Assistência no caso de Acidente Nuclear ou Emergência Radiológica, Viena, 1986. Decreto ${ }^{\circ} 9$ de 15/01/1991;

$\downarrow$ Convenção da Basiléia sobre Movimentos Transfronteiriços de Resíduos Perigosos e Seu Depósito, Basiléia, 1989. Decreto ${ }^{\circ} 875$ de 19/07/1993;

- Ajustes ao Protocolo de Montreal sobre Substâncias que Destroem a Camada de Ozônio, Montreal, 1990. Promulgados pelo Decreto $\mathrm{n}^{\circ} 181$ de 24/07/1991;

- Acordo entre o Governo da República Federativa do Brasil e as Nações Unidas relativo à Conferência das Nações Unidas sobre Meio Ambiente e Desenvolvimento, Rio de janeiro, 1991. Decreto $n^{\circ} 440$ de 06/02/1992;

- Convenção das Nações Unidas sobre o Direito do Mar, Montego Bay, 1982; aprovada pelo Decreto Legislativo $\mathrm{n}^{\circ} 5 / 97$, promulgada pelo Decreto $\mathrm{n}^{\circ} 99.165$ de 12/03/1990 e declarada em vigor no Brasil, pelo Decreto 1530 de 22 de junho de 1995; 
- Convenção sobre a Diversidade Biológica, Rio de Janeiro, 5 de junho de 1992, assinada pelo Brasil durante a ECO-92. Decreto 2.519 de 16/03/1998;

+ Convenção-Quadro das Nações Unidas sobre Mudança do Clima, adotada no Rio de Janeiro, em 1992, (por ocasião da ECO-92), promulgada pelo Decreto 2.652 de 01/07/1998;

\ Convenção Internacional para a Prevenção da Poluição Causada por Navios, MARPOL, Londres, 1973, (OMCI), juntamente com seu Protocolo de 1978, promulgados pelo Decreto 2.508 de 04 de abril de 1998, inclusive com a adoção dos Anexos III, IV e V, opcionais, da Convenção;

- Tratado sobre a Não Proliferação de Armas Nucleares, TNP, assinado em Londres, Moscou e Washington, em 01 de julho de 1968, aprovado pelo Decreto Legislativo $\mathrm{n}^{\circ} 65$ de 02 de julho de 1998, e promulgado pelo Decreto ${ }^{\circ} 2.864$ de 07 de dezembro de 1998;

- Convenção Internacional sobre o Preparo, Resposta e Cooperação em Caso de Poluição por Óleo. Assinada em Londres (OMI), a 30 de novembro de 1990 (conhecida pela sigla OPRC), promulgada pelo Decreto 2870 de 10/XII/1998;

Acordo Internacional sobre Madeiras Tropicais, assinado em Genebra em 1995 (UNCTAD), aprovado pelo Decreto Legislativo $\mathrm{n}^{\circ} 68$ de 04 de novembro de 1997 e promulgado pelo Decreto $n^{\circ} 2.707$ de 04 de agosto de 1998;

- Convenção das Nações Unidas para o Combate à Desertificação Naqueles Países que Experimentam Sérias Secas e/ou Desertificação, Particularmente na África, 17 de julho de 1994, Nova York (ONU). Texto remetido à aprovação do Congresso Nacional, com a Mensagem Presidencial $\mathrm{n}^{\circ} 697$ de 20 de janeiro de 1996. Promulgada pelo Decreto ${ }^{\circ} 2.741$ de 20/08/1998;

Emenda ao Protocolo de Montreal sobre Substâncias que Destroem a Camada de Ozônio, Londres, 1990. Mensagem Presidencial no 537 de 08/10/1991. Decreto 2.699 de 30/07/1998; 
Tratado de Não Proliferação de Armas Nucleares, TNP, adotado em $1^{\circ}$ de julho de 1968, em Genebra (Comissão de Desarmamento da ONU). Texto remetido ao Congresso Nacional, com a Mensagem 716 de 23/06/1997, para fins de autorização à adesão. Promulgado pelo Decreto $\mathrm{n}^{\circ} 2.864$ de 01//12/1998;

- Convenção relativa a Zonas Úmidas de Importância Internacional, Particularmente como Hábitat das Aves Aquáticas, Ramsar (Irã), 1971,e Protocolo de Emenda, adotado em Paris, a 1982. Aprovados pelo Decreto Legislativo $n^{\circ} 33$ de 16/06/1992. Decreto $n^{\circ} 1.905$ de 16/05/1996;

+ Protocolo ao Tratado da Antártica sobre Proteção ao Meio Ambiente, adotado em Madri em 1991. Aprovado pelo Decreto $\mathrm{n}^{\circ} 88$ de 06/06/1995. Promulgado pelo Decreto n ${ }^{\circ} 2.742$ de 20/08/1998;

- Convenção sobre a Probição do Desenvolvimento, Produção, Estocagem e Uso das Armas Químicas e sobre a Destruição das Armas Químicas Existentes no Mundo, negociada em Genebra (Comissão de Desarmamento) e adotada em Paris, a 13/01/1993. Aprovada pelo Decreto $n^{\circ} 9$ de 29/02/1996. Promulgada pelo Decreto $\mathrm{n}^{\mathrm{o}} 2.977$ de 01/03/1999;

- Emenda ao Protocolo de Montreal sobre Substâncias que Destroem a Camada de Ozônio, Londres, 1990. Mensagem Presidencial nº 537 de 08/10/1991. Decreto 2.699 de 30/07/1998;

+ Convenção das Nações Unidas para o Combate à Desertificação Naqueles Países que Experimentam Sérias Secas e/ou Desertificação, Particularmente na África, 17 de julho de 1994, Nova York (ONU). Mensagem Presidencial $n^{\circ} 697$ de 20 de janeiro de 1996. Decreto ${ }^{\circ}$ 2.741 de 20/08/1998;

- Tratado de Não Proliferação de Armas Nucleares, TNP, adotado em 01/07/1968, em Genebra. Mensagem $n^{\circ} 716$ de 23/06/1997, para fins de autorização à adesão. Decreto $\mathrm{n}^{\circ} 2.864 \mathrm{de} 01 / / 12 / 1998$;

Convenção sobre Diversidade Biológica, assinada no Rio de Janeiro, na ECO-92. Decreto Legislativo $n^{\circ} 2$, de 03.02.94; 
Protocolo de Cartagena sobre Biossegurança da Convenção sobre Diversidade Biológica, celebrado em Montreal, em 29.01.2000. Decreto Legislativo $n^{\circ}$ 908/2003;

Conferência das Nações Unidas sobre Meio Ambiente e Desenvolvimento - ECO-92. Decreto ${ }^{\circ} 440$, de 04.02.92;

\ Convenção - Quadro das Nações Unidas sobre Mudança do Clima, adotada em Nova Yorque, em 09.05.92. Decreto $n^{\circ} 1$, de 03.02.94;

- Convenção - Quadro das Nações Unidas sobre Mudança do Clima, assinada em Nova Yorque, em 09.05.92. Decreto $\mathrm{n}^{\circ} 2.652$, de 01.07.98;

- Protocolo de Quioto à Convenção-Quadro das Nações Unidas sobre Mudança do Clima, aberto a assinaturas na cidade de Quioto, Japão, em 14/12/1997, por ocasião da Terceira Conferência das Partes da Convenção-Quadro das Nações Unidas sobre Mudança do Clima. Decreto Legislativo $\mathrm{n}^{\circ} 144$, de 20.06.02;

- Convenção da Basiléia sobre o Controle de Movimentos Transfronteiriços de Resíduos Perigosos e seu Depósito. Decreto $\mathrm{n}^{\circ}$ 875, de 19.07.93. (Alteração incorporada: Decreto $\mathrm{n}^{\circ} 4.581$, de 27.01.03);

- Convenção Interamericana para a Proteção e a Conservação das Tartarugas Marinhas, concluída em Caracas, em 1/12/1996. Decreto $\mathrm{n}^{\circ} 3.842$, de 13.06.01;

- Convenção sobre Diversidade Biológica. Decreto $n^{\circ} 2.519$, de 16.03.98;

Acordo para conservação da fauna aquática nos cursos dos rios limítrofes - Brasil/Paraguai. Decreto $n^{\circ} 1.806$, de 06.02.96;

Convenção sobre Diversidade Biológica, dispõe sobre o acesso ao patrimônio genético, a proteção e o acesso ao conhecimento tradicional associado, a repartição de benefícios e 0 acesso à tecnologia e a transferência de tecnologia para sua conservação e utilização. MP n. 2.186-16, de 23.08.01. (Orientação Técnica CGPG n. 2, de 30.10.03 e Orientação Técnica CGPG n. 3, de 30.10.03); 
- Convenção sobre Comércio Internacional das Espécies da Flora e Fauna Selvagens em Perigo de Extinção - CITES. Decreto $n^{\circ} 3.607$, de 21.09.00;

- Convenção sobre Diversidade Biológica. Decreto n. 2.519, de 16.03.98;

Acordo Parcial para a Facilitação de Transporte de Produtos Perigosos no Mercosul. Decreto n. 1.797, de 25.01.96;

- Convenção sobre Prevenção da Poluição Marinha por Alijamento de Residuos e Outras Matérias, Londres, 29/12/1972. Decreto n. 87.566, de 16.09.82;

- Primeiro Protocolo Adicional ao Acordo de Alcance Parcial para a Facilitação do Transporte de Produtos Perigosos (AAP.PC/7), Brasil/Argentina/Paraguai/Uruguai. Decreto n. 2.866, de 07.12.98;

\ Instruções para a fiscalização do Transporte Rodoviário de Produtos Perigosos no Mercosul. Portaria MT n. 22, de 19.01.01;

- Convenção de Viena para Proteção da Camada de Ozônio e o Protocolo de Montreal sobre Substâncias que Destroem a Camada de Ozônio. Decreto n. 99.280, de 06.06.90;

- Ajustes ao Protocolo de Montreal sobre Substâncias que Destroem a Camada de Ozônio, de 1987. Decreto n. 181, de 24.07.91;

- Emendas ao Protocolo de Montreal sobre Substâncias que Destroem a Camada de Ozônio, adotadas em Londres a 29.06.90. Decreto Legislativo n. 32, de 16.06.92;

- Emendas ao Protocolo de Montreal sobre substâncias que Destroem a Camada de Ozônio, adotadas em Copenhague, em 25 de novembro de 1992. Decreto Legislativo n. 51, de 30.05.96;

+ Emendas ao Protocolo de Montreal sobre Substâncias que Destroem a Camada de Ozônio, assinadas em Copenhague, em 25 de novembro de 1991. Decreto n. 2.679, de 17.07.98;

\ Emenda ao Protocolo de Montreal sobre Substâncias que Destroem a Camada de Ozônio, assinada em Londres, em 29 de junho de 1990. Decreto n. 2.699, de 30.07.98. 
Rede Brasileira de Manejo Ambiental de Resíduos - REBRAMAR, integrada à Rede Pan Americana de Manejo Ambiental de Resíduos REPAMAR, coordenada a nível de América Latina e Caribe pelo Centro Pan Americano de Engenharia Sanitária e Ciências Ambientais - CEPIS. Portaria IBAMA n. 45, de 29.06.95;

- Movimento transfronteiriço de residuos. Resolução CONAMA n. 23, de 12.12.96. (Alterações incorporadas: Resoluções CONAMA n. 235/98 e 244/98). (Ver: Decreto n. 875, de 19.07.93);

- Convenção da Basiléia sobre o Controle de Movimentos Transfronteiriços de Resíduos Perigosos e seu Depósito. Decreto n. 875, de 19.07.93. (Alteração incorporada: Decreto n. 4.581, de 27.01.03);

- Rede Brasileira de Manejo Ambiental De Resíduos - REBRAMAR Constitui a Rede Brasileira de Manejo Ambiental de Resíduos REBRAMAR, integrada à Rede Pan Americana de Manejo Ambiental de Residuos - REPAMAR, coordenada em nível de América Latina e Caribe pelo Centro Pan Americano de Engenharia Sanitária e Ciências Ambientais - CEPIS. Portaria IBAMA n. 45, de 29.06.95;

- Atuação das Forças Armadas e da Polícia Federal nas Unidades de Conservação localizadas na faixa de fronteira. Participação do Ministério da Defesa na elaboração, análise e atualizações dos planos de manejo, os quais deverão ser submetidos à anuência prévia do Conselho de Defesa Nacional. Decreto n. 4.411, de 07.10.02;

- Convenção sobre Diversidade Biológica. Decreto n. 2.519, de 16.03.98;

Convenção sobre a Plataforma Continental, Genebra, 1958. Autorizada a Adesão pelo Decreto $n^{\circ} 45 / 68$;

- Convenção sobre Pesca e Conservação de Recursos Vivos do Alto Mar, Genebra, 1958. Autorizada a Adesão pelo Decreto Legislativo $n^{\circ}$ 45/68;

Convenção sobre o Alto Mar, Genebra, 1958. Autorizada a Adesão pelo Decreto Legislativo $n^{\circ} 45 / 68$; 
Protocolo de Quioto à Convenção-Quadro das Nações Unidas sobre Mudança do Clima, Kyoto, 10 de dezembro de 1997. Aprovado pelo Decreto Legislativo $\mathrm{n}^{\circ} 144$ de 20/06/02.

b) Cooperação em Matéria Ambiental/Regulamentação Internacional de Grandes Espaços/Rios e Bacias Hidrográficas

Acordo de Alcance Parcial de Cooperação e Intercâmbio de Bens Utilizados na Defesa e Proteção do Meio Ambiente entre Brasil e Argentina, Montevidéu, 1993. Decreto ${ }^{\circ} 652$ de 15/09/1992;

$\downarrow$ Paraguai - Tratado de Itaipu, Brasília, 1970. Decreto nº 72.707 de 28/08/1973;

- Protocolo Adicional sobre Relações de Trabalho e Previdência Social, Assunção, 1974. Decreto n 75.242 de 17/01/1975;

- Acordo Administrativo Regulamentador da Prestação de Serviços Médicos, Brasília, 1975 (publicado no Diário Oficial da União, de 16/01/1975);

- Ajuste Complementar ao Acordo de Cooperação Técnica sobre Cooperação em Matéria de Medição da Qualidade de Águas, Brasilia, 1991 ;

- Acordo Administrativo Complementar sobre Higiene e Segurança do Trabalho, Brasilia, 1975 (publicado no Diário Oficial da União, de 16/01/1975);

Acordo de Cooperação Técnica, 27/11/1987;

- Tratado de Cooperação para o Aproveitamento dos Recursos Naturais e o Desenvolvimento da Bacia da Lagoa Mirim (Tratado da Bacia da Lagoa Mirim) e Protocolo para o Aproveitamento dos Recursos Hídricos do Trecho Limítrofe do Rio Jaguarão, Anexo ao Tratado da Bacia da Lagoa Mirim (Protocolo do Rio Jaguarão), Brasília, 1977. Decreto $n^{\circ} 81.351$ de 17/02/1978; 
- Protocolo de Adesão da República de República Oriental do Uruguai, 1994. Decreto $n^{\circ} 1.478$ de 02/05/1995;

$\downarrow 3^{\circ}$ Memorando de Entendimento relativo ao Tratado da Lagoa Mirim e ao Protocolo sobre o Rio Jaguarão, Brasília, 1991;

\ Acordo de Cooperação Ambiental, Montevidéu, 28/12/1992;

- Convênio de Sanidade Animal em Áreas de Fronteiras, Brasília, 1977. Decreto $n^{\circ} 83.309$ de 04/0/1979;

Acordo de Cooperação Sanitária para a Região Amazônica, Bogotá, 1972. Decreto $\mathrm{n}^{\circ} 78.016$ de 12/07/1976;

- Ajuste Complementar ao Acordo de Cooperação Sanitária para a Região Amazônica, Brasília, dezembro de 1991;

- Acordo para a Conservação da Flora e da Fauna dos Territórios Amazônicos, Bogotá, 1973. Decreto $n^{\circ} 78.017$ de 12/07/1973;

Acordo para a Conservação da Flora e da Fauna dos Territórios Amazônicos, Lima, 1975. Decreto ${ }^{\circ} 78.802$ de 23/11/1976;

Acordo Sanitário para o Meio Tropical, a bordo do Navio Ycayali, da Armada peruana, em águas fronteiriças, 1976. Decreto $n^{\circ} 70.067$ de 02/08/1977;

- Acordo para a Utilização de Estações Costeiras e de Navios da Região Amazônica, a bordo do Navio Ycayali, da armada peruana, em águas fronteiriças, 1976. Decreto $n^{\circ} 83.141$ de 06/02/1979;

\ Tratado de Cooperação Amazônica, 1981. Decreto $n^{\circ} 92.661$ de 16/05/1986;

- Acordo de Cooperação Amazônica, Brasília, 1982. Decreto n 92.931 de 16/07/1986;

$\downarrow$ Tratado de Amizade e Cooperação, Brasília, 1969. Decreto $n^{\circ} 86.246$ de 30/07/1981;

- Acordo sobre Sanidade Animal em Áreas de Fronteira dos Dois Países, Caracas, 1979. Decreto $n^{\circ} 86.483$ de 16/10/1981;

+ Acordo sobre Cooperação Sanitária Fronteiriça, 1982. Decreto $n^{\circ} 59$ de 14/03/1991. 
c) Proteção à Flora e à Fauna/Pesca Internacional

- Ajuste Complementar ao Acordo Básico de Cooperação Técnica de 30.11.1963, sobre Projeto "Planejamento Pesqueiro Artesanal/SUDEPE", Brasília, 20/09/1984;

Ajuste Complementar ao Acordo Básico de Cooperação Técnica de 30.11.1963, sobre o Projeto " Planejamento Pesqueiro Artesanal/ SUDEPE, Brasília, 16/12I/1986;

Acordo de Conservação dos Recursos Naturais do Atlântico Sul, Buenos Aires, 1967. Decreto-Lei n ${ }^{\circ} 454$ de 05/02/1969;

Acordo sobre Empreendimentos Conjuntos no Setor da Pesca, Brasília, 15/02/1978.;

\ Memorando de Entendimento sobre Cooperação no Setor Pesqueiro, Brasilia, 19/02/1978;

- Acordo que cria um Grupo de Trabalho Especifico para a Cooperação nos Setores Agrícola, Pecuário, Florestal, Pesqueiro e Agroalimentar, Brasilia, 18/01/1983;

- Ata Conjunta relativa ao Acordo entre o Governo da República Federativa do Brasil e o Governo dos Estados Unidos da América sobre Camarão, Brasília, 09/05/1972;

- Notas Complementares ao Acordo sobre Camarão, Brasília, 09/05/1972;

- Entendimentos por troca de Notas Verbais, $n^{\circ} 85$, relativos à Operação do Acordo sobre Camarão de 09.05.1972, Brasília, 30/06/1972;

- Protocolo de Intenções sobre Requisitos Sanitários para o Comércio de Produtos de Pescado entre o Governo da República Federativa do Brasil e o Governo da República do Peru, celebrado em Brasília, a 29/11/1990;

- Acordo com Trinidade e Tobago, por Troca de Notas, sobre Pesca de Camarão, Brasília, em 24 e 28 de fevereiro de 1975; 
Acordo com Trinidade e Tobago, por Troca de Notas, sobre Empreendimentos Conjuntos no Setor da Pesca, Brasilia, 08/05/1978;

Acordo de Pesca e Preservação dos Recursos Vivos, Montevidéu, 12/12/1968. Decreto-Lei $n^{\circ} 412$ de 09/01/1969;

- Convênio Zoossanitário para o Intercâmbio de Animais e de Produtos de Origem Animal, Montevidéu, 14/08/1985. Decreto $n^{\circ} 674$ de $26 / 10 / 1992$.

d) Atos Internacionais na Área Nuclear e de Cooperação Científica e Tecnológica

- Tratado de Proibição Completa dos Testes Nucleares (conhecido pela sigla de sua denominação em inglês, CTBT, "Comprehensive TestBan Treaty"), adotado por ocasião da LI Assembléia Geral da ONU, em Nova York, em setembro de 1996 e assinado pelo Brasil a 24/09/1996.

\ Acordo Básico de Cooperação entre a Alemanha e o Brasil, Bonn, aos 30/11/1963;

- Acordo Geral de Cooperação no Setor de Pesquisa Científica e de Desenvolvimento Tecnológico, Bonn, 09/06/1969;

+ Convênio Especial entre a Comissão Nacional de Energia Nuclear e o Centro de Pesquisa Nuclear de Jülich (KFA), de Cooperação Tecnológica, Brasília, 23/04/1973;

- Adendo ao Convênio Especial CNEN-KFA, Bonn, 03/10/1973;

- Convênio sobre a Entrada de Navios Nucleares em Águas Brasileiras e Sua Permanência em Portos Brasileiros, Brasília, 07/06/1972. Decreto $\mathrm{n}^{\circ} 74.600$ de 24/09/1974;

Acordo sobre Cooperação no Campo dos Usos Pacíficos da Energia Nuclear, Bonn, 27/06/1975; 
Acordo entre o Governo do Brasil, o Governo da Alemanha e a Agência Internacional de Energia Atômica para a Aplicação de Salvaguardas, Viena, 26/02/1976;

- Convênio Especial entre Empresas Nucleares Brasileiras S.A. NUCLEBRAS e Gesellschaft für Kernforschung - GFK sobre Cooperação no Campo dos Usos Pacíficos da Energia Nuclear, Brasília, 01/10/1976;

- Convênio Especial entre a Secretaria de Tecnologia Industrial do Ministério da Indústria e Comércio e Centro Nuclear de Jülich de Tecnologia Industrial, a 08/03/1978;

\ Convênio Especial entre a Comissão Nacional de Energia Nuclear CNEN e o Centro de Pesquisa Nuclear de Karlsruhe - KFK sobre Cooperação no Campo dos Usos Pacificos da Energia Nuclear, 08/03/1978;

- Ajuste entre o Ministério das Minas e Energia do Brasil e o Ministério Federal do Interior da Alemanha sobre Intercâmbio de Informações Técnicas e Cooperação no Campo de Segurança de Instalações Nucleares, Bonn, 10/03/1978;

- Acordos sobre Projetos Conjuntos entre a CNEN e o KFA:

- Para o Desenvolvimento e Testes de Componentes do Ciclotron, 30/08/1985;

- Para Pesquisa Experimental da Combinação e Fluxo do Aquecimento Crítico em Feixe de Varetas do Tipo Geométrico PWR, 30/06/1986;

- Para Supervisão do Código da CNEN de Controle de Material Nuclear, de 23/10/1986;

- Para o Estabelecimento de um Sistema de Medidas para Conferência do Material Nuclear Aplicável a FEC e a NUCLEI, 23/10/1986;

Acordo sobre Projeto Conjunto entre a CNEN e o KFK no Campo da Física da Saúde, 26/03/1986; 
- Memorando de Entendimento entre o Ministério das Minas e Energia da República Federativa do Brasil e o Ministério Federal da Pesquisa e Tecnologia da República Federal da Alemanha, Brasilia, 29/08/1989;

- Convênio de Cooperação entre o Governo da República Federativa do Brasil e o Governo da República Argentina para o Desenvolvimento e a Aplicação dos Usos Pacíficos da Energia Nuclear, Buenos Aires, 17/05/1980;

- Convênio de Cooperação entre a Comissão de Energia Nuclear da República Federativa do Brasil e a Comissão Nacional de Energia Atômica da República Argentina para o Desenvolvimento e a Aplicação dos Usos Pacíficos da Energia Nuclear, Buenos Aires, 17/05/1980;

† Convênio de Cooperação entre Empresas Nucleares Brasileiras S.A., NUCLEBRAS da República Federativa do Brasil e a Comissão Nacional de Energia Atômica da República Argentina, Buenos Aires, 17/05/1980;

\ Protocolo de Execução n ${ }^{\circ} 1$ para Cooperação no Campo da Formação de Recursos Humanos no Setor Nuclear, Brasília, 20/08/1980;

- Protocolo de Cooperação Industrial entre Empresas Nucleares Brasileiras de República Federativa do Brasil e a Comissão Nacional de Energia Atômica da República Argentina, Brasilia, 30/11/1985;

+ Declaração Conjunta sobre Política Nuclear, Foz de Iguaçu, 30/11/1986;

+ Declaração Conjunta sobre Política Nuclear, Brasília, 10/12/1986;

- Protocolo $n^{\circ} 11$ sobre Pronta Notificação e Assistência Mútua em Casos de Acidentes Nucleares e Emergências Radiológicas, Buenos Aires, 29/07/1986;

Anexo I ao Protocolo $n^{\circ} 11$, sobre Pronta Notificação Mútua em Caso de Acidentes Nucleares e Emergências Radiológicas, Brasilia, 10/12/1986; 
- Anexo II ao Protocolo $n^{\circ} 11$, entre CNEN e a CNEA, sobre Segurança e Radioproteção, Brasilia, 10/12/1986;

- Ata da $3^{a}$ Reunião do Grupo de Trabalho Conjunto sobre Política Nuclear, Sub-Grupo Técnico, Rio de Janeiro, 26 e 27/11/1986;

- Declaração Conjunta dos Governos do Brasil e da Argentina sobre Política Nuclear, Brasília, 10/12/1986;

+ Protocolo $n^{\circ}$ 17, sobre Cooperação Nuclear, Brasília, 10/12/1986;

- Declaração Conjunta dos Governos do Brasil e da Argentina sobre Política Nuclear, Viena, 17/07/1989;

+ Acordo para o Uso Exclusivamente Pacífico da Energia Nuclear, Guadalajara (México), de 18 de julho de 1991;

- Protocolo Adicional sobre Privilégios e Imunidades ao Acordo para o Uso Exclusivamente Pacífico da Energia Nuclear, Brasília, de 20/08/1991. Decreto $n^{\circ} 515$, de 19/04/1992;

- Acordo entre a República Federativa do Brasil, a República Argentina, a Agência Brasileiro-Argentina de Contabilidade e Controle de Materiais Nucleares e a Agência Internacional de Energia Atômica, para a Aplicação de Salvaguardas, Viena, 13/12/1991.

- Acordo de Cooperação Científica, Tecnológica e Técnica com a Argélia, Brasilia, 03/07/1981;

- Memorando de Entendimento entre o Governo da República Federativa do Brasil e o Governo da Austrália para Consultas sobre Assuntos de Interesse Comum, Brasília, 27/08/1990;

- Acordo sobre Cooperação no Campo dos Usos Pacíficos da Energia Atômica, La Paz, 11/01/1966;

Acordo de Cooperação Técnica com o Canadá, 02/04/1975;

Acordo Básico de Cooperação Científica, Santiago, 19/07/1974;

- Memorando de Entendimento sobre Cooperação em Atividades Científicas, Tecnológicas, Desenvolvimento e de Aplicação Prática da Energia Nuclear com Fins Pacíficos, Santiago, em 10/10/1980;

Acordo de Cooperação referente aos Usos Civis da Energia Atômica, 08/07/1965; 
- Memorando de Entendimento entre o Governo da República Federativa do Brasil e o Governo da República Popular da China sobre Cooperação nos Usos Pacíficos da Energia Nuclear, Beijing, 29/05/1984;

Acordo de Cooperação no Campo dos Usos Pacíficos da Energia Nuclear, entre o Governo da República Federativa do Brasil e o Governo da República Popular da China, Pequim, 11/10/1984;

Acordo de Cooperação sobre os Usos Pacíficos da Energia Nuclear entre os Governos da República Federativa do Brasil e o Governo da República da Colômbia, Bogotá, 12/03/1981;

Acordo Básico de Cooperação Técnica entre o Governo dos Estados Unidos do Brasil e o Governo do Reino da Dinamarca, Rio de Janeiro, 25/02/1966;

Acordo sobre Cooperação no Campo dos Usos Pacíficos da Energia Atômica, Quito, 11/06/1970;

- Plano de Trabalho sobre Cooperação Científica e Técnica no Quadro de Cooperação Técnica e Científica entre a República Federativa do Brasil e a República Árabe do Egito, Cairo, 18/09/1984;

Acordo de Cooperação sobre a Utilização da Energia Atômica para Fins Pacificos, Madri, 27/05/1968;

- Acordo de Cooperação no Campo dos Usos Pacíficos da Energia Nuclear entre o Governo da República Federativa do Brasil e o Governo da Espanha, Brasilia, 12/05/1983. Promulgado pelo Decreto $\mathrm{n}^{\circ} 830$ de 03/06/1993;

- Acordo de Cooperação para Usos Civis da Energia Atômica entre o Governo dos Estados Unidos da América e o Governo dos Estados Unidos do Brasil, 03/08/1955;

Acordo de Cooperação para Usos Civis da Energia Atômica entre o Governo dos Estados Unidos da América e o Governo dos Estados Unidos do Brasil, Washington, 31/07/1957;

Acordo de Cooperação relativo aos Usos Civis da Energia Atômica, Washington, 17/07/1972; 
Aditamento ao Contrato de Arrendamento de Material Fissil Especial entre o Governo dos Estados Unidos do Brasil e a Comissão de Energia Atômica dos Estados Unidos da América, Representando o Governo dos Estados Unidos da América, 25/09/1957;

Acordo relativo à Concessão de Donativos pelo Governo dos Estados Unidos da América, Destinados a Auxiliar o Governo Brasileiro na Aquisição de Certos Materiais para Reatores Nucleares de Pesquisa, 10/10/1960;

- Acordo Trilateral para Aplicação de Salvaguardas, entre a República Federativa do Brasil, os Estados Unidos da América e a Agência Internacional de Energia Atômica, 10/03/1967;

- Ajuste para o Intercâmbio de Informações Reguladoras e de Cooperação em Pesquisa da Segurança entre a Comissão Nacional de Energia Nuclear e a United National Regulatory Commission USNRC, Washington, 20/05/1976;

- Carta de Intenção de Acordo entre o Laboratório de Medicina Nuclear e Biologia da Radiação da Universidade da Califórnia de Los Angeles e a Comissão Nacional de Energia Nuclear-CNEN, sob o Patrocínio do Departamento de Energia dos EUA, Rio de Janeiro, 25/09/1980;

Acordo entre o Governo da República Federativa do Brasil e o Governo dos Estados Unidos da América para a Cooperação em Ciência e Tecnologia, Brasília, 06/02/1984;

- Acordo de Cooperação entre o Comissariat à l'Energie Atomique da França e a Comissão Nacional de Energia Nuclear do Brasil, para a Utilização da Energia Nuclear para Fins Pacíficos, 01/03/1958;

Acordo entre os Estados Unidos do Brasil e a República Francesa sobre Utilização de Energia Atômica para Fins Pacificos, 02/03/1962;

- Acordo Básico de Cooperação Técnica e Científica entre o Governo dos Estados Unidos do Brasil e o Governo da República Francesa, Paris, 16/01/1967;

- Acordo Básico de Cooperação Técnica entre o Governo dos Estados Unidos do Brasil e o Governo de Israel, Recife, 12/03/1962; 
- Convênio de Cooperação para o Projeto de Experiência Crítica "Cobra", entre a Companhia Brasileira de Tecnologia Nuclear, CBTN e o Comissariado de Energia Atômica da França, CEA, Paris, 10/05/1974;

- Acordo, por Troca de Notas, para o Estabelecimento das Condições de Utilização do Hexafluoreto de Urânio entre o Governo da República Federativa do Brasil e o Governo da República Francesa, 06/01/1981;

- Acordo entre o Governo da República Federativa do Brasil e o Governo da Índia sobre Cooperação para Utilização Pacífica da Energia Nuclear, 18/12/1968;

Acordo entre o Governo da República Federativa do Brasil e o Governo da Índia sobre Cooperação nos Campos da Ciência e Tecnologia, Nova Delhi, 22/07/1985;

Acordo entre o Governo da República Federativa do Brasil e a República do Iraque sobre Usos Pacíficos da Energia Nuclear, 05/01/1980;

屯 Primeiro Convênio Complementar ao Acordo Básico de Cooperação Técnica entre Brasil e Israel, Rio de Janeiro, 11/05/1966;

- Atas de Entendimentos Realizados entre a Comissão Nacional de Energia Nuclear- CNEN e a Comissão de Energia Atômica de IsraelCEAI, Rio de janeiro, 15/12/1967;

- Acordo de Cooperação entre o Governo dos Estados Unidos do Brasil e o Governo da República Italiana para o Uso Pacífico da Energia Nuclear, Rio de Janeiro, 06/09/1958;

- Programa de Implantação do Acordo de Cooperação para os Usos Pacificos da Energia Nuclear, entre o Brasil e Itália, Brasilia, 13/08/1971;

Acordo Básico de Cooperação Técnica entre o Governo da República Federativa do Brasil e o Governo da República Italiana, Brasília, 30/10/1972; 
- Programa de Execução do Acordo de Cooperação entre o Governo da República Italiana e a República Federativa do Brasil, no Campo dos Usos Pacíficos da Energia Nuclear, Brasilia, 29/07/1981;

- Declaração Conjunta da CNEN do Brasil, do Commitato Nazionale per l'Energia Nucleare da Itália e da Nucleare Italiana Reatori Avanzati (NIRA), relativa à Colaboração no Campo das Aplicações Pacificas da Energia Nuclear, Brasília, 29/07/1981;

- Programa de Execução do Acordo de Cooperação entre o Governo da República Italiana e a República Federativa do Brasil, no Campo dos Usos Pacificos de Energia Nuclear, Brasilia, 20/07/1981;

$\downarrow$ Contrato para o Fornecimento de Circuitos e Equipamentos para Tecnologia do Sódio, Brasilia, 29/07/1981;

- Acordo entre a Comissão Nacional de Pesquisa e Desenvolvimento da Energia Nuclear e das Energias Alternativas (ENA) e a Comissão Nacional de Energia Nuclear (CNEN) para a Troca de Informações Técnicas relativas à Segurança Nuclear e à Proteção Sanitária contra as Radiações;

- Acordo sobre Cooperação Econômica e Industrial entre o Governo da República Federativa do Brasil e o Governo da República Italiana, Roma, 18/10/1982;

- Memorando de Execução da Cooperação para o Desenvolvimento de Conformidade com o Acordo Básico de Cooperação Técnica, Roma, 17/10/1989;

\ Acordo Quadro para a Cooperação Econòmica, Industrial, CientíficoTecnológica, Técnica e Cultural, 1989;

- Acordo para a Destinação Definitiva dos Rejeitos Radioativos do Acidente de Goiânia, Roma, 11/12/1991;

- Acordo Básico de Cooperação Técnica entre o Governo dos Estados Unidos do Brasil e a República Popular Federativa da lugoslávia, Rio de Janeiro, 11/03/1962;

- Acordo Básico de Cooperação Técnica entre o Governo da República Federativa do Brasil e o Governo do Japão, 22/09/1970; 
Acordo entre o Governo da República Federativa do Brasil e o Governo do Japão sobre Cooperação no Campo da Ciência e Tecnologia, Tóquio, 25/05/1984;

- Acordo de Cooperação Técnica, Científica e Tecnológica entre a República Federativa do Brasil e a Jamairia Árabe Socialista da Líbia, Brasília, 30/06/1978;

屯 Acordo de Cooperação Econômica, Cientifica e Técnica entre o Governo da República Federativa do Brasil e o Governo da República Federal da Nigéria, Brasilia, 10/01/1979;

- Acordo sobre Cooperação no Campo dos Usos Pacíficos de Energia Atômica entre os Estados Unidos do Brasil e a República do Paraguai, Assunção, 18/08/1961;

\ Acordo sobre Cooperação no Campo dos Usos Pacíficos de Energia Atômica entre a República dos Estados Unidos do Brasil e a República do Peru, Lima, 30/11/1966;

- Acordo Básico de Cooperação Científica e Técnica entre a República Federativa do Brasil e a República do Peru, 08/10/1975;

\ Acordo de Cooperação no Campo dos Usos Pacíficos da Energia Nuclear entre a República Federativa do Brasil e a República do Peru, Lima, 26/06/1981;

- Acordo entre os Governos do Brasil e de Portugal para a Cooperação na Utilização da Energia Nuclear para Fins Pacíficos, Rio de Janeiro, 18/06/1965;

Acordo Básico de Cooperação Técnica entre os Governos do Brasil e Portugal, Lisboa, 07/09/1966;

Acordo Básico de Cooperação Técnica entre o Governo do Brasil e o Reino Unido da Grã-Bretanha e Irlanda do Norte, Rio de Janeiro, 18/01/1968;

Acordo entre a Autoridade de Energia Atômica do Reino Unido e a Comissão Nacional de Energia Nuclear do Brasil, referente à Cooperação nas Aplicações Pacificas de Energia Atômica 18/11/1974; 
- Memorando de Entendimento entre o Governo da República Federativa do Brasil e o Governo do Reino Unido da Grã-Bretanha e Irlanda do Norte, Londres, 02/12/1981;

Acordo de Cooperação Cientifica e Tecnológica entre o Governo da República Federativa do Brasil e o Governo da República Socialista da Romênia, Brasília, 12/05/1981;

Acordo entre o Governo da República Federativa do Brasil e o Governo da Suécia sobre Cooperação Econômica, Industrial e Tecnológica, Brasília, 03/04/1984;

Acordo de Cooperação para a Utilização da Energia Atômica para Fins Pacíficos entre os Estados Unidos do Brasil e a Confederação Suiça, Rio de Janeiro, 26/05/1965;

- Acordo de Cooperação Técnica e Científica entre a República Federativa do Brasil e a Confederação Suíça, Rio de Janeiro, 26/04/1968;

- Acordo Básico de Cooperação Científica e Técnica entre o Governo da República Federativa do Brasil e o Governo da República Oriental do Uruguai;

- Acordo Básico de Cooperação Científica e Tecnológica entre o Governo da República Federativa do Brasil e o Governo da União das Repúblicas Socialistas Soviéticas, Moscou, 16/04/1981;

† Convênio de Amizade e Cooperação entre a República Federativa do Brasil e a República da Venezuela, Brasilia, 17/11/1977;

- Acordo de Cooperação sobre os Usos Pacíficos da Energia Nuclear entre a Comissão Nacional de Energia Nuclear-CNEN e o Conselho Nacional para o Desenvolvimento da Indústria Nuclear na Venezuela CONADIN, Caracas, a 27/07/1979;

- Acordo de Cooperação entre a República Federativa do Brasil e a República da Venezuela, na Área da Energia Nuclear para Fins Pacíficos, Caracas, 30/11/1983. 


\section{A.4. Norma para classificação dos cursos d'água brasileiros quanto ao domínio}

RESOLUÇÃO N 399, DE 22 DE JULHO DE 2004

Altera a Portaria $\mathrm{n}^{\circ} 707$, de 17 de outubro de 1994, do Departamento Nacional de Águas e Energia Elétrica - DNAEE, e dá outras providências

O DIRETOR-PRESIDENTE DA AGÊNCIA NACIONAL DE ÁGUAS ANA, no uso da atribuição que lhe confere o art. 16, inciso III, do Regimento Interno, aprovado pela Resolução no 9, de 17 de abril de 2001, torna público que a DIRETORIA COLEGIADA, em sua $133^{\mathrm{a}}$ Reunião Ordinária, realizada em 22 de julho de 2004, com fundamento no art. 4o, inciso II, da Lei no 9.984, de 17 de julho de 2000, tendo em vista os elementos constantes do Processo no 02501.001393/2004-95, e

Considerando que a ANA sucedeu ao Departamento Nacional de Águas e Energia Elétrica - DNAEE nas competências relativas à gestão de recursos hídricos;

Considerando que a caracterização da unidade de um curso de água por seu nome nas cartas oficiais exige a sua identificação inequivoca, com a determinação precisa do ponto onde adquire a denominação e onde esta termina;

Considerando que a toponímia em uma carta oficial não indica nomes para todos os cursos de água e, quando o faz, expressa dúvidas, com freqüência, na forma de dois ou mais nomes ligados pela preposição "ou" e que, ademais, não são indicados nas cartas os pontos onde tal denominação se inicia e onde termina, tornando frágil e subjetivo o processo de identificação do curso principal por meio de nomes; 
Considerando os avanços tecnológicos havidos na área de geoprocessamento e informação após a publicação da Portaria $\mathrm{n}^{\circ} 707$, de 17 de outubro de 1994, do DNAEE; e

Considerando a necessidade de se estabelecer os critérios para a classificação dos cursos de água brasileiros com base técnica sólida, objetiva e inequívoca, resolveu:

Art. $1^{\circ}$ Alterar o item 5. CRITÉRIOS TÉCNICOS PARA IDENTIFICAÇÃO DOS CURSOS D'ÁGUA do Anexo da Portaria $n^{\circ}$ 707, de 1994, do DNAEE, que aprovou a NORMA PARA CLASSIFICAÇÃO DOS CURSOS D'ÁGUA BRASILEIROS QUANTO AO DOMÍNIO - NORMA DNAEE $N^{\circ} 06$, o qual passa a vigorar com a seguinte redação:

\section{“5. CRITÉRIOS TÉCNICOS PARA IDENTIFICAÇÃO DOS CURSOS D'ÁGUA}

5.1. Cada curso d'água, desde a sua foz até a sua nascente, será considerado como unidade indivisível, para fins de classificação quanto ao dominio.

5.2. Os sistemas hidrográficos serão estudados, examinando-se as suas correntes de água sempre de jusante para montante e iniciando-se pela identificação do seu curso principal.

5.3. Em cada confluência será considerado curso d'água principal aquele cuja bacia hidrográfica tiver a maior área de drenagem.

5.4. A determinação das áreas de drenagem será feita com base na Cartografia Sistemática Terrestre Básica.

5.5. Os braços de rios, paranás, igarapés e alagados não serão classificados em separado, uma vez que são considerados parte integrante do curso d'água principal."

Art. $2^{\circ}$ Ficam ratificadas as demais disposições da Portaria $n^{\circ} 707$, de 1994, do DNAEE, não alteradas por esta Resolução. 
PORTARIA DNAEE N. 707, DE 17.10.94

O Diretor do Departamento Nacional de Águas e Energia Elétrica DNAEE, no uso de suas atribuições regimentais e considerando a necessidade de se estabelecer critérios para a classificação, quanto ao dominio, dos cursos d'água brasileiros, de conformidade com o inciso III do artigo 20 e o inciso I do artigo 26, da Constituição da República Federativa do Brasil, de 1988, resolve:

Art. $1^{\circ}$ - Aprovar a Norma para Classificação dos Cursos D'água Brasileiros quanto ao Domínio - Norma DNAEE n. 6, em anexo. Art. $2^{\circ}$ - Esta Portaria entra em vigor na data de sua publicação.

ANEXO À PORTARIA N. 707, DE 17.10.94

Norma para Classificação dos Cursos D'água Brasileiros quanto ao Domínio - Norma DNAEE $N^{\circ} 06$

1 - Objetivo:

Esta Norma tem por objetivo, estabelecer os critérios adotados pelo Departamento Nacional de Águas e Energia Elétrica - DNAEE para a classificação dos cursos d'água brasileiros quanto ao domínio, tendo em vista as atribuições regimentais do DNAEE, no campo dos recursos hídricos, conferidas pela Portaria MME n. 65, de 11 de fevereiro de 1993, publicada no "Diário Oficial" da União em 12 de fevereiro de 1993.

2 - Fundamentos Legais:

Os critérios para classificação, quanto ao dominio, dos cursos d'água brasileiros estão fundamentados no inciso III do artigo 20 da Constituição da República Federativa do Brasil, de 1988, que classifica como bens da União: 
"... os lagos, rios e quaisquer correntes de água em terrenos de seu dominio, ou que banhem mais de um Estado, sirvam de limites com outros paises, ou se estendam a território estrangeiro ou dele provenham, bem como os terrenos marginais e as praias fluviais;..."

Fundamentam-se ainda no artigo 26 da Constituição, inciso I, que define como bens dos Estados: "... as águas superficiais ou subterrâneas, fluentes, emergentes e em depósito, ressalvadas, neste caso, na forma da lei, as decorrentes de obras da União ...".

3 - Critérios Jurídicos para Identificação dos Cursos D'água Federais:

São de dominio federal os lagos, rios e quaisquer correntes de água que:

3.1 - banhem mais de um Estado, servindo de limite entre eles ou cruzando sua divisa;

3.2 - sirvam de limites com outros paises;

3.3 - se estendam a território estrangeiro ou dele provenham;

3.4 - estejam situados totalmente dentro de terrenos de domínio da União, tais como:

3.4.1 - as terras devolutas indispensáveis à defesa das fronteiras, das fortificações e construções militares e das vias federais de comunicação, definidas em lei;

3.4.2 - as terras devolutas indispensáveis à preservação ambiental, definidas em lei;

3.4.3 - as ilhas fluviais e lacustres nas zonas limitrofes com outros países;

3.4.4 - as praias marítimas, as ilhas oceânicas e as ilhas costeiras, excluídas destas, aquelas cujo domínio não seja da União;

3.4.5 - os terrenos de marinha e seus acrescidos;

3.4.6 - as terras tradicionalmente ocupadas pelos indios.

3.5 - incluem-se também, na forma da lei, as águas em depósito, tais como as de reservatórios, açudes e barragens, decorrentes de obras da União. 
4 - Critérios Jurídicos para Identificação dos Cursos D'água Estaduais:

São de domínio estadual:

4.1 - as águas subterrâneas;

4.2 - as águas superficiais, fluentes e emergentes, não classificadas como de domínio federal;

4.3 - as águas em depósito, ressalvadas, neste caso, na forma da lei as decorrentes de obras da União;

4.4 - cabe salientar ainda que o domínio dos Estados sobre as águas de jurisdição estadual, situadas nas zonas periodicamente assoladas pelas secas, fica limitado pela competência da União de legislar sobre tais zonas, de acordo com o artigo $29, \S 2^{\circ}$, do Código de Águas (Decreto n. 23.643, de 10 de julho de 1934).

\section{CRITÉRIOS TÉCNICOS PARA IDENTIFICAÇÃO DOS CURSOS} $D^{\prime A ́ G U A}{ }^{144}$

5.1. Cada curso d'água, desde a sua foz até a sua nascente, será considerado como unidade indivisível, para fins de classificação quanto ao domínio.

5.2. Os sistemas hidrográficos serão estudados, examinando-se as suas correntes de água sempre de jusante para montante e iniciando-se pela identificação do seu curso principal.

5.3. Em cada confluência será considerado curso d'água principal aquele cuja bacia hidrográfica tiver a maior área de drenagem.

5.4. A determinação das áreas de drenagem será feita com base na Cartografia Sistemática Terrestre Básica.

5.5. Os braços de rios, paranás, igarapés e alagados não serão classificados em separado, uma vez que são considerados parte integrante do curso d'água principal.

${ }^{144}$ Com redação dada pela Resolução ANA n. 399, de 02.07.04. 